\title{
JARDIM JAQUELINE
}

A disputa pela paisagem entre a cidade formal e a ocupação espontânea

Tatiana Zamoner 


\section{Tatiana Zamoner Geraldo}

\section{JARDIM JAQUELINE}

A disputa pela paisagem entre a cidade formal e a ocupação espontânea

EXEMPLAR REVISADO E ALTERADO EM RELAÇÃO À VERSÃO ORIGINAL, SOB RESPONSABILIDADE DO AUTOR E ANUÊNCIA DO ORIENTADOR.

O ORIGINAL SE ENCONTRA DISPONÍVEL NA SEDE DO PROGRAMA SÃO PAULO, O3 DE FEVEREIRO DE 2014

Dissertação apresentada à Faculdade de Arquitetura e Urbanismo da Universidade de São Paulo para obtenção do título de Mestre em Arquitetura e Urbanismo

Área de Concentração: Paisagem e Ambiente

Orientadora: Prof. ${ }^{a}$ Dr. ${ }^{a}$ Catharina Pinheiro Cordeiro dos Santos Lima 
Autorizo a reprodução e divulgação total ou parcial deste trabalho, por qualquer meio convencional ou eletrônico, para fins de estudo e pesquisa, desde que citada a fonte.

\section{Assinatura:}

tatianazamoner@gmail.com

\section{Geraldo, Tatiana Zamoner}

G354j Jardim Jaqueline : a disputa pela paisagem entre a cidade

formal e a ocupação espontânea. / Tatiana Zamoner Geraldo - São Paulo, 2013.

159 p. : il.

Dissertação (Mestrado - Área de Concentração: Paisagem e Ambiente) - FAUUSP.

Orientadora: Catharina Pinheiro Cordeiro dos Santos Lima

1. Favelas - São Paulo 2. Paisagem urbana 3. Cultura

I.Título

Segue as normas do Novo Acordo Ortográfico da Língua Portuguesa, em vigor desde janeiro de 2009.

Diagramado, padronizado e revisado por Amália Cristovão dos Santos.

IMAGENS DAS CAPAS E LOMBADA Acervo da autora

TIPOLOGIA Titillium Text22L 


\section{AGRADECIMENTOS}

Agradeço a todos que contribuíram e se envolveram no processo de investigação proposto, em especial:

À minha orientadora, Catharina Lima, pelo apoio e constante motivação no processo de pesquisa;

À banca de qualificação, formada pelas professoras Vera Pallamin e Laura Bueno, pelas importantes contribuições, que foram em grande parte incorporadas à dissertação;

A Elisabete Silva e Nivea Maria da Silva dos Santos Miranda, da Associação União de Moradores do Jardim Jaqueline, pelas valiosas informações prestadas ao longo do processo;

A todos os moradores do Jardim Jaqueline e moradores do entorno, que contribuíram com a nossa pesquisa, por meio de depoimentos informais e participação nas oficinas propostas;

A Vania Bartalini e Taís D'Aquino, pelas conversas e horizontes apresentados a respeito da pesquisa qualitativa;

A Amália dos Santos, pelos trabalhos finais de revisão e diagramação;

À família, pela paciência. 


\section{RESUMO}

O estudo de uma paisagem específica e sua interação com a cidade revela apropriações e representações de nosso tempo. 0 Jardim Jaqueline é analisado por meio de dados quantitativos, relativos a estatísticas, inserção urbana e políticas públicas, aliados ao processo de investigação qualitativa, que pretende entender as problemáticas relativas à paisagem por meio do cruzamento de olhares entre moradores e pesquisadora. Os dados revelados ao longo da pesquisa nos permitem traçar uma linha de investigação que foge de um conceito de paisagem ligado ao meio natural, relativo a uma representação dominante, adentrando um campo investigativo em que a paisagem é resultado de seu contexto histórico e cultural, configurando-se como forte símbolo de poder e apropriação cultural. A pesquisa sai do meio natural para voltar a ele, quando o caminho investigativo proposto nos auxilia na compreensão das possibilidades de intervenção na paisagem, com seus limites e potencialidades.

Palavras-chave: Favela. Paisagem. Cultura. 


\section{ABSTRACT}

The research about a specific landscape and its interaction with the city reveals appropriations and representations of our time. The neighborhood of Jardim Jaqueline, in São Paulo, is analyzed through quantitative data concerning statistics, urban insertion and public policies, allied to a qualitative research process which aims to understand landscape issues through the intersection of perceptions between its inhabitants and the researcher. The data revealed throughout the research enable us to draw a line of investigation that escapes from a landscape concept linked to the natural environment and related to a dominant representation, and enters an investigative field where landscape is seen as the result of its historical and cultural context, thus representing a strong symbol of power and cultural appropriation. The research leaves the natural environment to return to it, when the proposed investigative process helps us to understand the possibilities of intervention in the landscape, with its limits and potentialities.

Key words: Slums. Landscape. Culture. 


\section{LISTA DE FIGURAS}

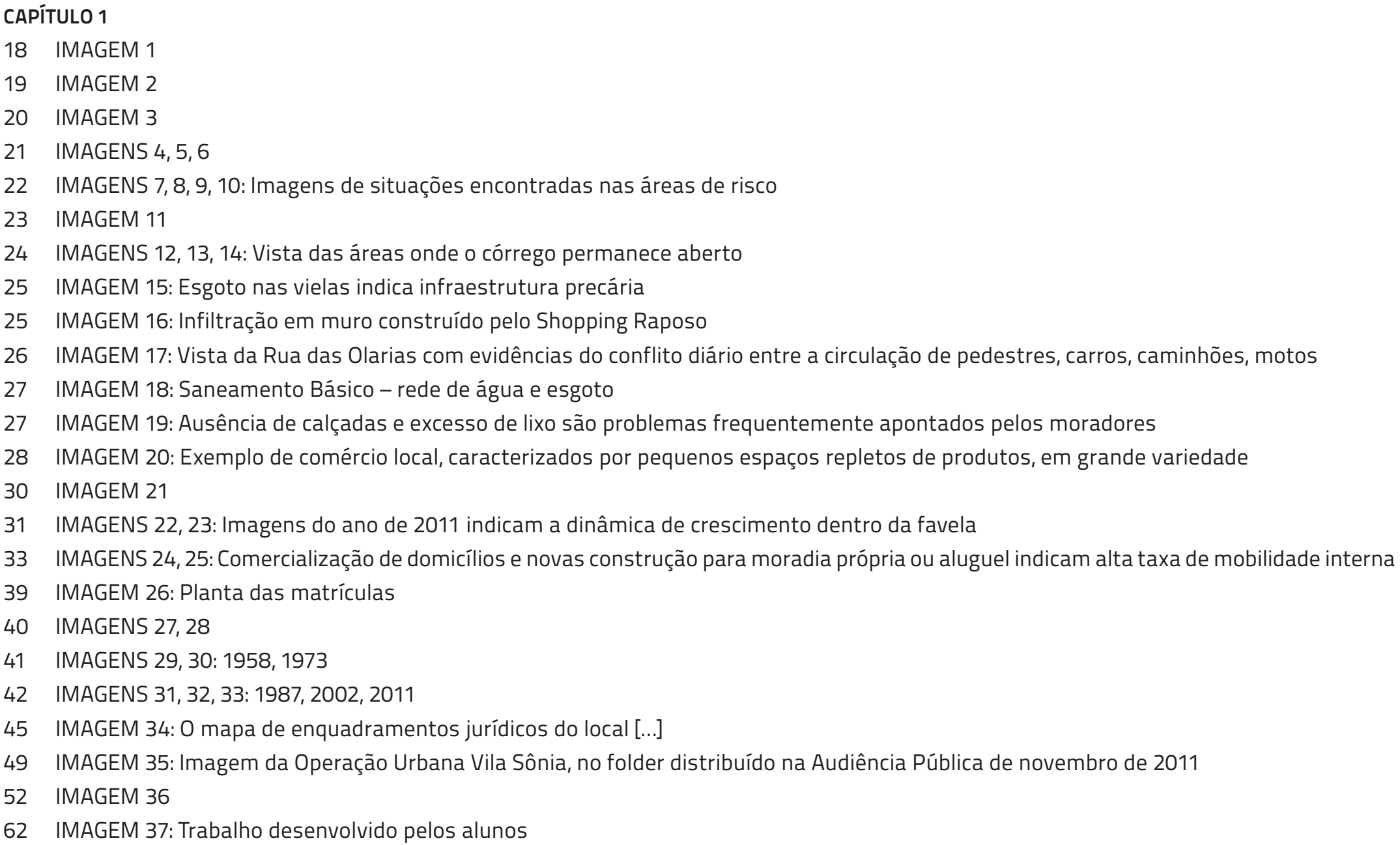




\section{CAPITULOO 2}

71 IMAGENS 1, 2, 3: Imagens extraídas do filme "Restos", de João Batista de Andrade

72 IMAGENS 4, 5: Casas construídas sobre o córrego

73 IMAGEM 6: Casa na Rua Alessandro Bibiena

75 IMAGENS 7, 8, 9, 10: Área verde ocupada pelo Shopping, em vistas da Rua Sebastião Gonçalves

77 IMAGEM 11: Folder do Projeto de Pré-Regularização da Eletropaulo

78 IMAGEM 12: Portal construído em concreto indica intenção de fechamento de viela, que não foi efetivada [...]

81 IMAGEM 13: Planta parcial do parcelamento do solo proposto para o processo de regularização fundiária

86 IMAGEM 14: Peculiar apropriação sob torre de transmissão da Eletropaulo evidencia a ausência de espaços de convivência na favela

86 IMAGEM 15: Crianças brincam nas ruas estreitas sem calçadas

87 IMAGEM 16: Faixa colocada no campo de futebol da Rua Sebastião Gonçalves indica conflitos no uso do espaço

87 IMAGENS 17, 18: Imagens do muro construído para conter o crescimento da favela

88 IMAGEM 19: Palco localizado na Rua Sebastião Gonçalves

88 IMAGENS 20, 21: Imagens mostram diversos usos dados ao palco da princesinha, localizado em um pequeno largo e importante referência na favela

90 IMAGEM 22: Sede da Associação de Moradores

92 IMAGEM 23: Propostas de intervenção [...]

93 IMAGEM 24: Espaços ocupados por garagens e pequenos comércios na Rua Sebastião Gonçalves

93 IMAGEM 25: Vista do único espaço vazio dentro da favela, utilizado como campo de futebol, na Rua Sebastião Gonçalves

98 IMAGEM 26: Vista do muro de divisão entre o Shopping e a favela

99 IMAGENS 27, 28: Imagens a partir da sacada do apartamento da moradora do conjunto Espaço Raposo

102 IMAGENS 29, 30: Imagens da passarela de pedestres que atravessa a Rodovia Raposo Tavares

103 IMAGEM 31: Crianças estudam em área improvisada em tapumes sobre o córrego

\section{CAPÍTULO 3}

114 IMAGENS 1, 2: Espaços liminares

115 IMAGENS 3, 4: Paisagem vista a partir do Parque

116 IMAGENS 5, 6: Nascentes tamponadas

118 IMAGEM 7: Rodovia Raposo Tavares

120 IMAGEM 8: Parque Raposo Tavares, nas proximidades do Jardim Jaqueline

121 IMAGEM 9: Vista do Jardim Jaqueline, tomada a partir do Shopping 
123 IMAGENS 10, 11, 12, 13: Imagens das diversas áreas do Parque Raposo Tavares e seus usos pelos frequentadores

124 IMAGEM 14: Exemplo de opção de lazer dentro do Shopping

125 IMAGENS 15, 16: Imagens do empreendimento Smiley Home Resort

132 IMAGENS 17, 18

140 IMAGENS 19, 20, 21: Stills do documentário "Vhils - Descascando a Superfície"

141 IMAGENS 22, 23: Imagens do conjunto habitacional desenhado pelo arquiteto Ruy Ohtake em Heliópolis e do projeto do Cantinho do Céu

142 IMAGENS 24, 25: Imagens extraídas da tese de Laura Machado Mello Bueno (2000)

\section{LISTA DE TABELAS}
CAPÍTULO 1
34 TABELA 1
36 TABELA 2
36 TABELA 3
38 TABELA 4

\section{LISTA DE GRÁFICOS}
CAPÍTULO 1
28 GRÁFICO 1
29 GRÁFICO 2
30 GRÁFICO 3
31 GRÁFICO 4
32 GRÁFICO 5
32 GRÁFICO 6
34 GRÁFICO 7
36 GRÁFICO 8
36 GRÁFICO 9 


\section{SUMÁRIO}

12 INTRODUÇÃO

17 CAPÍTULO 1. CARACTERIZAÇÃO DO OBJETO

17 1. APRESENTAÇÃO DO OBJETO DE ESTUDO

18 1.1. LOCALIZAÇÃO E CONTEXTO URBANO

20 1.2. MEIO BIOFÍSICO E INFRAESTRUTURA LOCAL

20 1.2.1. MEIO BIOFÍSICO

25 1.2.2. MORFOLOGIA E INFRAESTRUTURA LOCAL

26 1.3. CARACTERIZAÇÃO SOCIOECONÔMICA

27 1.3.1. RESULTADO DO LEVANTAMENTO QUANTITATIVO: QUEM SÃO OS MORADORES DO JARDIM JAQUELINE?

37 2. EVOLUÇÃO URBANA: O JARDIM JAQUELINE E O CRESCIMENTO DAS FAVELAS EM SÃO PAULO

38 2.1. HISTÓRICO DE OCUPAÇÃO DO JARDIM JAQUELINE

44 2.2. O PROCESSO DE OCUPAÇÃO DAS APPS

46 3. A OPERAÇÃO URBANA CONSORCIADA VILA SÔNIA: MODELO DE DESENVOLVIMENTO PROPOSTO PARA A REGIÃO

47 3.1. A OPERAÇÃO URBANA CONSORCIADA VILA SÔNIA (OUCVS)

51 3.2. PARQUES LINEARES PROPOSTOS

53 4. LUTA POR DIREITOS

53 4.1. TRAJETÓRIA RUMO À REGULARIZAÇÃO FUNDIÁRIA

59 4.2. A LUTA CONTINUA: CAMINHOS PARA A REGULARIZAÇÃO URBANISTICA

61 5. PROJETO E O RECONHECIMENTO DE UMA IDENTIDADE

65 1. O CAMINHO DA PESQUISA QUALITATIVA: DESAFIOS E POTENCIALIDADES

68 2. PRIMEIRA OFICINA COM MORADORES DO JARDIM JAQUELINE - OFICINA DE APROXIMAÇÃO

69 2.1. A APRESENTAÇÃO DA PESQUISA E CONTRIBUIÇÕES INICIAIS DOS MORADORES

76 2.2. INFORMES INTERNOS

78 2.3. PRINCIPAIS PONTOS DE REFLEXÃO

82 3. SEGUNDA OFICINA - CONFLITOS E POTENCIALIDADES 
83 3.1. A CONSTRUÇÃO DA PROPOSTA

86 3.2. AS DEMANDAS DE SEMPRE E NOVAS POSSIBILIDADES

89 3.3. AS DETERMINAÇÕES LOCAIS - SOBRE A "NOSSA CULTURA"

90 3.4. EQUIPAMENTOS PÚBLICOS E PARTICIPAÇÃO SOCIAL

91 3.5. A NECESSIDADE DE UM PROJETO E A POSSIBILIDADE DE DESLOCAMENTOS

94 3.6. OS INTERESSES INDIVIDUAIS E O SACRIFÍCIO DO ESPAÇO COLETIVO

95 3.7. PRINCIPAIS PONTOS DE REFLEXÃO

97 4. A CIDADE LEGAL OLHA A FAVELA

101 4.1. INTER-RELAÇÕES ENTRE O DENTRO E O FORA

102 5. CONSIDERAÇÕES A RESPEITO DA PESQUISA QUALITATIVA COMO FERRAMENTA DE ESTUDO NA PAISAGEM

108 CAPÍTULO 3. CONTRUÇõES POSSIVEIS DE UMA PAISAGEM EM MEIO AO URBANO PRECÁRIO

110 1. O SURGIMENTO DA IDÉIA DE PAISAGEM E SEUS SIGNIFICADOS

112 1.1. CARACTERIZAÇÃO DAS PAISAGENS CONTEMPORÂNEAS

113 2. MAPEANDO CULTURA E PODER

117 2.1. A CAPACIDADE DE DESLOCAMENTO COMO INSTRUMENTO DE PODER

119 2.2. FORMAS DE APROPRIAÇÃO DA PAISAGEM: A ESTRATÉGIA DA CULTURA

122 3. ENCLAUSURAMENTO E APARTAMENTO SOCIAL COMO CONDICIONANTES DA CONFIGURAÇÃO DAS PAISAGENS URBANAS

126 4. OS SENTIDOS DA CULTURA DA INFORMALIDADE EXPRESSOS NAS PAISAGENS

130 5. O IDEAL DO HOMEM QUE HABITA

132 5.1. SUBJETIVIDADE, CIDADANIA E EMANCIPAÇÃO: UMA EQUAÇÃO EM CONSTANTE (DES)EQUILÍBRIO

135 6. A PAISAGEM DA FAVELA DENTRO DE UM CONFLITO ANUNCIADO

138 6.1. MEDIAÇÕES E REPRESENTAÇÕES

144 7. O PRINCÍPIO PEDAGÓGICO OU O PROCESSO DE EMERGÊNCIA DA PAISAGEM

146 7.1. O PRINCÍPIO DE AMPLIAÇÃO DA CIDADANIA

150 CONSTRUÇÃO DE RESULTADOS E DESAFIOS COLOCADOS

154 BIBLIOGRAFIA 


\section{INTRODUÇÃO}

Iniciamos nossa incursão pelo universo referencial do Jardim Jaqueline, em 2010, quando a arquiteta-urbanista recém-chegada no Núcleo de Habitação e Urbanismo da Defensoria Pública estabelece os primeiros contatos com o que seria seu principal trabalho na instituição: o acompanhamento técnico do processo de regularização fundiária do Jardim Jaqueline. Projeto inédito e corajoso, que pretende, de forma pioneira, em meio ao ordenamento jurídico vigente, resgatar uma imensa favela, encravada em uma área em processo de valorização imobiliária, de sua condição de precariedade e insegurança na posse. Curiosa a necessidade de se investir tanta energia e trabalho na efetivação de um direito que teoricamente já estaria assegurado, dado o tempo de existência - mais de 30 anos - e o visível estágio de consolidação da área, devidamente inserida em uma ZEIS.

Um olhar geral sobre o objeto escolhido revela a extensa gama de possibilidades de estudo, considerando-se o cenário visível de uma favela consolidada, vizinha de um condomínio fechado e de um Shopping Center, implantada sobre dois cursos d'água, e inserida nos limites de uma Operação Urbana Consorciada. A presença de um instrumento urbanístico, atualmente utilizado como modelo de desenvolvimento urbano, e historicamente devassador em relação aos assentamentos de baixa renda que encontra pelo caminho, aliado à 'moda" dos parques lineares, que também vem assolando os pobres que ocupam as margens dos cursos d'água, nos instiga a pensar em diversas linhas de pesquisa provenientes de um mesmo objeto.

Após dois anos de envolvimento com os trabalhos de regularização fundiária e de investigações propostas pela nossa pesquisa, a proximidade com o lugar despertou outras possibilidades, dadas não só pelo contexto particular exposto - com a presença do tão discutido conflito entre meio ambiente e assentamentos de baixa renda -, do nefasto processo de valorização imobiliária e da curiosa divisão espacial entre alta e baixa renda, mas principalmente pelo trabalho desenvolvido por sua Associação de Moradores, com forte representatividade e influência no cotidiano local.

Um imenso universo referencial passou a se delinear, derivado de dados oficiais, visitas periódicas, inúmeras conversas informais, trabalho de resgate histórico (em grande parte oral) e oficinas com os moradores. A experiência da paisagem construiu as opções e caminhos percorridos, que estão aqui resumidos nos três capítulos desta dissertação. Do referencial jurídico desenvolvido nos trabalhos da instituição, que diz respeito à sua competência, colocamos apenas poucas referências, restando um imenso referencial teórico da área jurídica para ser desenvolvido por pesquisadores da área. 
Para nós, arquitetos-urbanistas, aliados a outras áreas fundamentais do conhecimento, como a sociologia, a antropologia e a filosofia, são colocados outros desafios, como a inserção dessas paisagens específicas, ligadas aos assentamentos das populações de baixa renda dentro de um contexto discursivo e referencial de nossa época, fortemente ligado às questões ambientais inseridas na lógica da 'sustentabilidade"; ao processo de exclusão socioespacial, ditado pelas elites econômicas; e aos padrões de comportamento ditados pelo consumo. 0 processo de investigação proposto, além de possibilitar o necessário entendimento das reais determinações envolvidas em nosso contexto urbano específico, dá instrumentos para olhares pensantes e propositivos em relação à paisagem.

Nossa paisagem, situada em meio a um cenário bem conhecido nas grandes cidades, em que a população de baixa renda ocupa os locais menos favoráveis aos assentamentos humanos, nas Áreas de Preservação Permanente dos cursos d'água, possui muitas narrativas. Dentro dessas narrativas, a cidade formal não escapa de suas responsabilidades em relação à precarização dos recursos naturais e da vida nas cidades, se considerados os estilos de vida de uma classe média urbana, que se reproduzem em todas as classes e comprometem todos os segmentos sociais que a habitam.

Temos a clareza de que estudar essa favela agora, em 2013, traz especificidades históricas que diferem de um olhar sobre a mesma favela antes de 2000, quando ainda não existiam seus nobres vizinhos ou a atual estrutura interna de poder. Da mesma forma, futuros estudiosos poderão encontrar outras determinações, que poderão demandar novas formas de atuação sobre a paisagem.

Diante do contexto e de nossos objetivos em relação ao estudo da paisagem, compreendemos, a duras penas, que o sentido que atribuímos à paisagem não poderia ser prontamente investido no imaginário coletivo local. A abordagem do contexto de convivência entre a favela e os córregos poderia ser outra até a década de 1990, quando ainda era possível visualizar o córrego e todos sabiam de onde ele vinha, pelo contato físico com suas nascentes. A compreensão dos nossos limites locais em relação à abordagem da paisagem e de suas dinâmicas, em que pudemos reconhecer um 'conflito simbólico" pelos referenciais de paisagem existentes, nos deram o caminho de enfrentamento da questão. Mesmo seguindo um caminho que foge das determinações naturais e sensíveis do meio, nosso objetivo inicial, de defesa da paisagem - dentro dessa falsa lógica de incompatibilidade entre pobres e meio ambiente - não foi abandonado.

Nosso método de abordagem pretende traçar as linhas de força existentes no campo de disputas entre paisagens. Os modos de vida dos moradores da favela, com seus valores, identidades e representações, em suas interações com o dentro e o fora, trazem problemáticas que não podem ser desconsideradas em planos ou projetos sobre a paisagem específica. 
O que tais determinações possuem de específico e em que medida fazem parte de forças externas ditadas pelo poder econômico e seus braços ideológicos são dados importantes para a visualização dos limites estruturais existentes em qualquer projeto de intervenção. Apesar dos fortes limites conjunturais, acreditamos que a intervenção em favelas é necessária e que, após as colocações aqui apresentadas, não podemos aceitar as formas ideológicas com que nos são impostos grandes projetos de intervenção, como os parques lineares.

O primeiro capítulo traz a construção do objeto de estudo, que parte de uma apresentação clássica do local inserido no espaço urbano, com suas relações física, social, econômica e ambiental. Suas características físicas, juntamente com os dados estatísticos que caracterizam seus habitantes, fazem parte dos resultados dos trabalhos técnicos realizados no âmbito do processo de regularização fundiária, promovido pela Defensoria Pública do Estado de São Paulo. Aos dados locais, foram comparados dados estatísticos e pesquisas acadêmicas que tratam da evolução urbana dos assentamentos de baixa renda em São Paulo.

Após exposição do objeto propriamente dito, apresentamos a análise das políticas públicas propostas para a região, com destaque à Operação Urbana Consorciada Vila Sônia (OUCVS), modelo de desenvolvimento proposto pela prefeitura municipal, que deverá trazer novos desdobramentos ao contexto urbano da favela. 0 capítulo inicial procura traçar um panorama do local, ao mesmo tempo que pretende evidenciar o apartamento entre as políticas públicas propostas, que, na esteira do mercado imobiliário, entende a cidade como oportunidade de investimentos e geração de lucros, e as dinâmicas locais, que apesar de inseridas dentro de uma mesma lógica econômica, possuem desdobramentos específicos.

O segundo capítulo toma uma distância oportuna em relação ao universo de análises quantitativas disponíveis, procurando adentrar um campo de conhecimento em que podem emergir dimensões sensíveis ligadas ao contexto situado da paisagem. A partir dessa abordagem, a utilização do instrumento da pesquisa qualitativa procura percorrer dados subjetivos, igualmente importantes à pesquisa científica, que os levantamentos quantitativos não alcançam. As necessidades apontadas nas oficinas de campo revelaram questões determinantes relativas à nossa paisagem, como formas de apropriação, desejos e potencialidades, que apontam um universo político e cultural que evidencia a complexidade dos temas a serem enfrentados no capítulo seguinte. Entendemos que as oficinas foram fundamentais para os desdobramentos finais da pesquisa. Apesar do vasto universo semântico associado ao conceito de paisagem, as oficinas 
possibilitaram uma linha de entendimento capaz de problematizar o nosso campo de investigação, fortemente associado ao campo da cultura.

A partir dos dados revelados pelas oficinas, o terceiro capítulo busca desenvolvimentos teóricos possíveis para a compreensão dos temas associados. O entendimento do processo de enclausuramento e apartamento social nos dá bases explicativas para os fenômenos vistos nas relações entre a favela, o condomínio e o Shopping. A delimitação das paisagens urbanas contemporâneas, dentro das estratégias de poder de uma apropriação cultural hegemônica, com seus processos de enobrecimento decorrente de projetos de intervenção urbana, evidencia as forças envolvidas na fisionomia de nossa paisagem e em suas formas de apropriação. Os chamados 'agenciamentos cotidianos" da vida, dentro do entendimento proposto por Vera da Silva Telles e Daniel Hirata, dialogam diretamente com os temas tratados nas oficinas com os moradores.

Às determinações que se relacionam diretamente com nossa paisagem, somam-se os mecanismos estruturantes de controle social, associados à lógica de consumo contemporânea, que ditam os ideais de convivência coletivos e de apropriação da cidade. 0 desenvolvimento teórico posterior às oficinas sugeriu o título do trabalho, Jardim Jaqueline: A disputa pela paisagem entre a cidade formal e a ocupação espontânea.

Dentro da polissemia envolvida no termo paisagem, em sua interação interdisciplinar, no processo de construção histórico-cultural da ideia de paisagem, a construção de uma paisagem não está necessariamente relacionada à construção física do espaço, mas a um conjunto de práticas, valores e percepções em relação ao espaço que podem, como desdobramento, alterar sua configuração física. Trata-se de um entendimento diverso do contido na maioria das intervenções paisagísticas promovidas nos centros urbanos, que considera o projeto físico, apartado das dinâmicas sociais, como via preferencial de alteração da paisagem.

Considera-se que a questão não pode ser enfrentada a partir da aplicação da lei ou de uma abordagem que leve em conta somente os elementos naturais, atentando para o fato de que, sem a devida inserção social e apropriação do lugar por parte dos moradores, qualquer projeto de recuperação ambiental (stricto sensu) tem grandes chances de fracassar, do ponto de vista social e ambiental.

Para a abordagem de nosso contexto, formado por uma favela específica, inserida em um eixo de desenvolvimento imobiliária, é de suma importância o desenvolvimento teórico em relação às paisagens existentes e possíveis, como contra- 
ponto à ideia corrente de que as favelas somente ganhariam uma paisagem quando submetidas a projetos de urbanização, pré-formatados e aplicáveis em série, como a maioria dos projetos habitacionais conhecidos. O estudo de uma 'não paisagem" - que supostamente desprovida de áreas livres ou locais onde seus moradores pudessem se exprimir e cujas histórias supostamente poderiam ser resumidas nas estatísticas de pobreza e exclusão social que acompanham o crescimento das grandes metrópoles - revela um universo desconhecido a ser explorado. 


\section{CAPÍTULO 1. CARACTERIZAÇÃO DO OBJETO}

O estudo de um objeto específico, no caso uma favela determinada, deve dialogar com o conjunto de conhecimentos disponíveis a respeito da evolução dos assentamentos de baixa renda no município de São Paulo e na região metropolitana. Temos um importante universo teórico referencial a respeito da precariedade urbana e dos conflitos socioambientais no processo de ocupação das grandes cidades, mas, ao contrário das importantes estatísticas que temos sobre o tema e características gerais de desenvolvimento urbano, que enquadram a tipologia favela dentro da lógica de reprodução urbana das grandes cidades, o olhar situado contribui para o entendimento das especificidades dos lugares, entendidos como paisagens, e o potencial de transformação contido em organizações e contextos sociais locais. O objetivo deste capítulo é expor o objeto de estudo, por meio de dados empíricos derivados de vistorias no local, de conversas informais com moradores, principalmente suas lideranças, e dos levantamentos quantitativos realizados para o processo de regularização fundiária do Jardim Jaqueline, promovidos pela Defensoria Pública do Estado de São Paulo (DPESP) entre 2011 e 2012.0 S dados quantitativos levantados serão confrontados com estatísticas e pesquisas acadêmicas desenvolvidas no município, de forma a construir o campo de similaridades e especificidades em relação ao objeto investigado. A construção do objeto se dará em diversas escalas de análise, do local ao regional, com a apresentação de planos e projetos municipais importantes para o entendimento de seu contexto urbano e dimensão sociopolítica.

\section{APRESENTAÇÃO DO OBJETO DE ESTUDO}

O Jardim Jaqueline é a segunda maior favela localizada na subprefeitura do Butantã, região oeste do município de São Paulo, próxima à Rodovia Raposo Tavares e à Avenida Eliseu de Almeida, em região que sofrerá os impactos decorrentes da implantação da linha amarela do metrô. Trata-se de uma região valorizada do ponto de vista fundiário e imobiliário, com tendência crescente de valorização decorrente de uma nova Operação Urbana promovida pela Prefeitura Municipal, a Operação Urbana Consorciada Vila Sônia, que deverá promover o adensamento da área e atrair novos empreendimentos residenciais de classe média alta. A área onde está inserida a favela foi delimitada pelo Plano Diretor Estratégico do município, de 2002, como ZEIS 1 - W35, Zona Especial de Interesse Social 1, denominação dada a favelas e assentamentos informais localizados em áreas urbanas providas de infraestrutura. Seguindo a regra de grande parte dos assentamentos informais localizados nos grandes centros urbanos, o Jardim Jaqueline ocupa as APPs (Áreas de Preservação Permanentes) de dois 
cursos d'água. O assentamento tem como acesso principal a Rodovia Raposo Tavares, tendo como vizinhos o Shopping Raposo Tavares e o Parque homônimo, além de um grande empreendimento residencial de classe média alta, chamado Condomínio Espaço Raposo, construído sobre um terreno grafado pelo Plano Diretor municipal como ZEIS 2, terminologia dada a terrenos localizados em área urbana consolidada que deveriam ser reservados à promoção de Habitação de Interesse Social. No entorno também existem outros assentamentos precários, como a favela Vale da Esperança, contígua ao Jardim Jaqueline, além da faixa de servidão da linha de transmissão da Eletropaulo e da Petrobrás.

De acordo com o Plano Municipal de Habitação de São Paulo de 2009 $(\mathrm{PMH})$, estão previstas intervenções na área somente no quarto quadriênio, ou seja, de 2021 a 2024, com estimativas de $R \$ 130$ milhões para atendimento da demanda habitacional de toda a subprefeitura do Butantã. Até o final de 2012, a prefeitura municipal trabalhava com a possibilidade de antecipação de obras de urbanização no Jardim Jaqueline e em outras favelas da região, com a aprovação da Operação Urbana Vila Sônia, que garantiria o montante de recursos necessários.

\subsection{LOCALIZAÇÃO E CONTEXTO URBANO}

A subprefeitura do Butantã é formada pelos distritos do Butantã, Morumbi, Raposo Tavares, Rio Pequeno e Vila Sônia e faz divisa com os municípios de Guarulhos e Taboão da Serra. A grande diversidade entre os distritos é dada pelo padrão de renda de seus moradores e padrões distintos de uso e ocupação do solo. O distrito de Vila Sônia apresenta grande concentração de empreendimentos de classe média alta, que convivem com assentamentos precários e áreas industriais e de serviços ao longo da Rodovia Raposo Tavares. Os bairros Jardim Leonor, Jardim Colombo, Portal do Morumbi e Super Quadra Morumbi são formados por empreendimentos de alto padrão, em ruas arborizadas, com grandes áreas

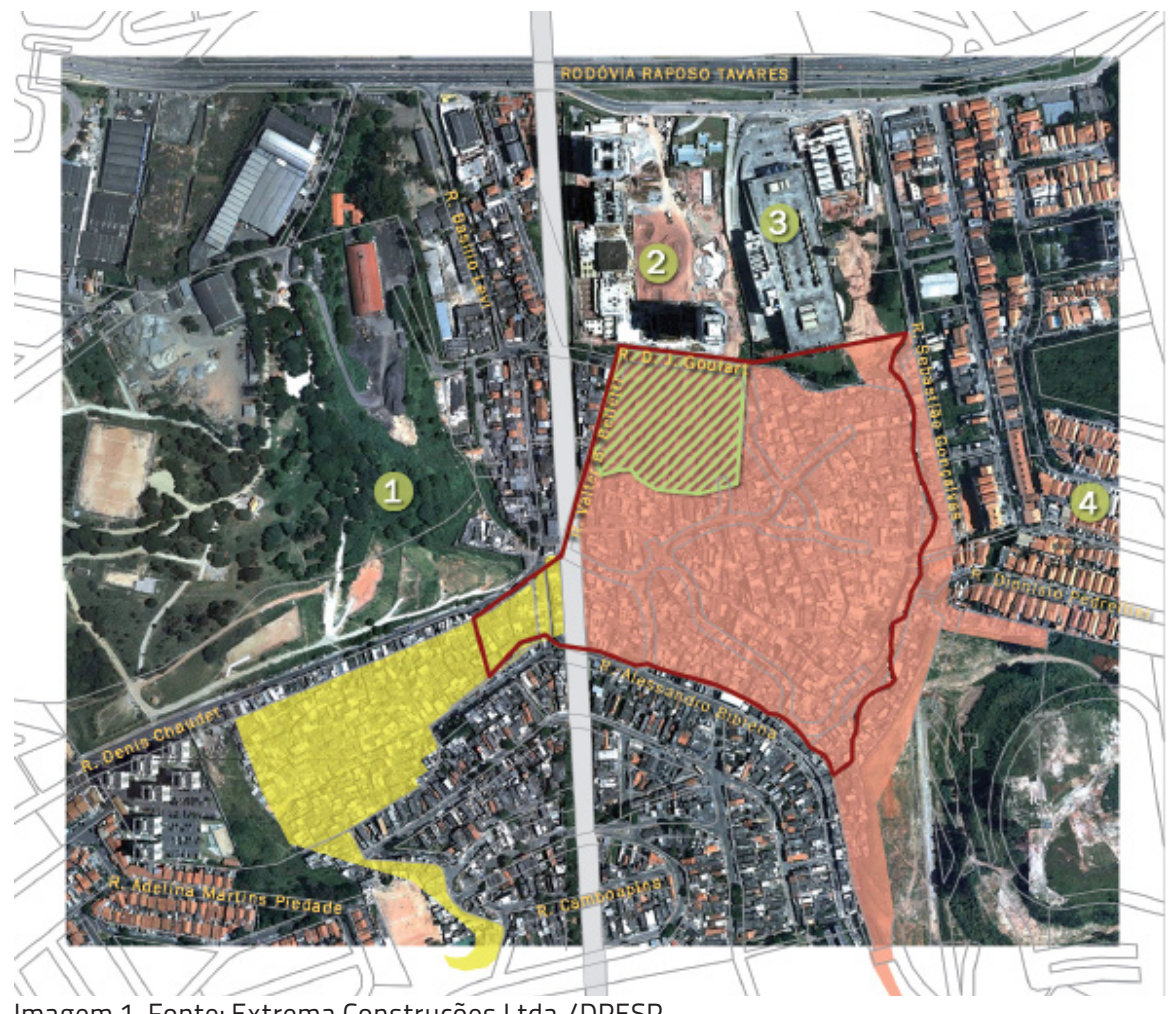

Imagem 1. Fonte: Extrema Construções Ltda./DPESP

legenda

ZEIS $1-W 035$ ZEIS 1 - W 034

Loteamento Vila Albano

Matrícula 49.609

Linha de transmissão da eletropaulo

1. Parque RaposoTavares 2. Condominio Espaço Raposo (ZEIS 2) 4. Condomínio da City 
permeáveis, que contrastam com o padrão de ocupação das favelas do distrito. Nos demais bairros predominam o uso residencial de médio e baixo padrão, com grande taxa de impermeabilização do solo.

Em relação ao crescimento verificado no distrito, entre 1996 e 2008, a população da Vila Sônia passou de 85.599 habitantes para 90.196, um crescimento de em torno de 5\%. Em 2008, a densidade demográfica era de aproximadamente 9 hab. $/ \mathrm{km}^{2}$. Destaca-se a tendência de verticalização, verificada nos atuais lançamentos imobiliários.

De acordo com o mapa de zoneamento', todo o entorno do Jardim Jaqueline está inserido em uma Zona Mista de Proteção Ambiental (ZMp), definida como "porções do território destinadas à implantação de usos urbanos de baixa densidade de ocupação, com gabarito de altura máxima de até 15 metros para as edificações". Sobrepondo-se à ZMp, a ZEIS 1 do Jardim Jaqueline, ocupada por população de baixa renda, estabelece novos parâmetros de uso e ocupação do solo, conflitantes com o zoneamento do entorno, revelando um conflito anunciado entre condicionantes de ordem ambiental e social.

O entorno imediato da favela possui grande variedade de equipamentos públicos, como o Parque Raposo, três Creches Municipais, o Centro de Referência da Assistência Social (CRAS), uma Unidade Básica de Saúde (UBS) e duas escolas de educação infantil. Um pouco mais distante, destaca-se o CEU Butantã, que conta com atividades diversificadas que englobam educação, cultura, esporte e entretenimento. Além dos equipamentos públicos, destaca-se a presença do Shopping Raposo Tavares, importante referência para os moradores da favela.

Como pode ser visto nos mapas, a favela é inserida em área próxima a importantes eixos de deslocamento viário, como a Rodovia Raposo Tavares e a Avenida Eliseu de Almeida, que garantem acessibilidade em relação ao centro da cidade e principais centralidades, e é atendida por linhas de ônibus municipais e

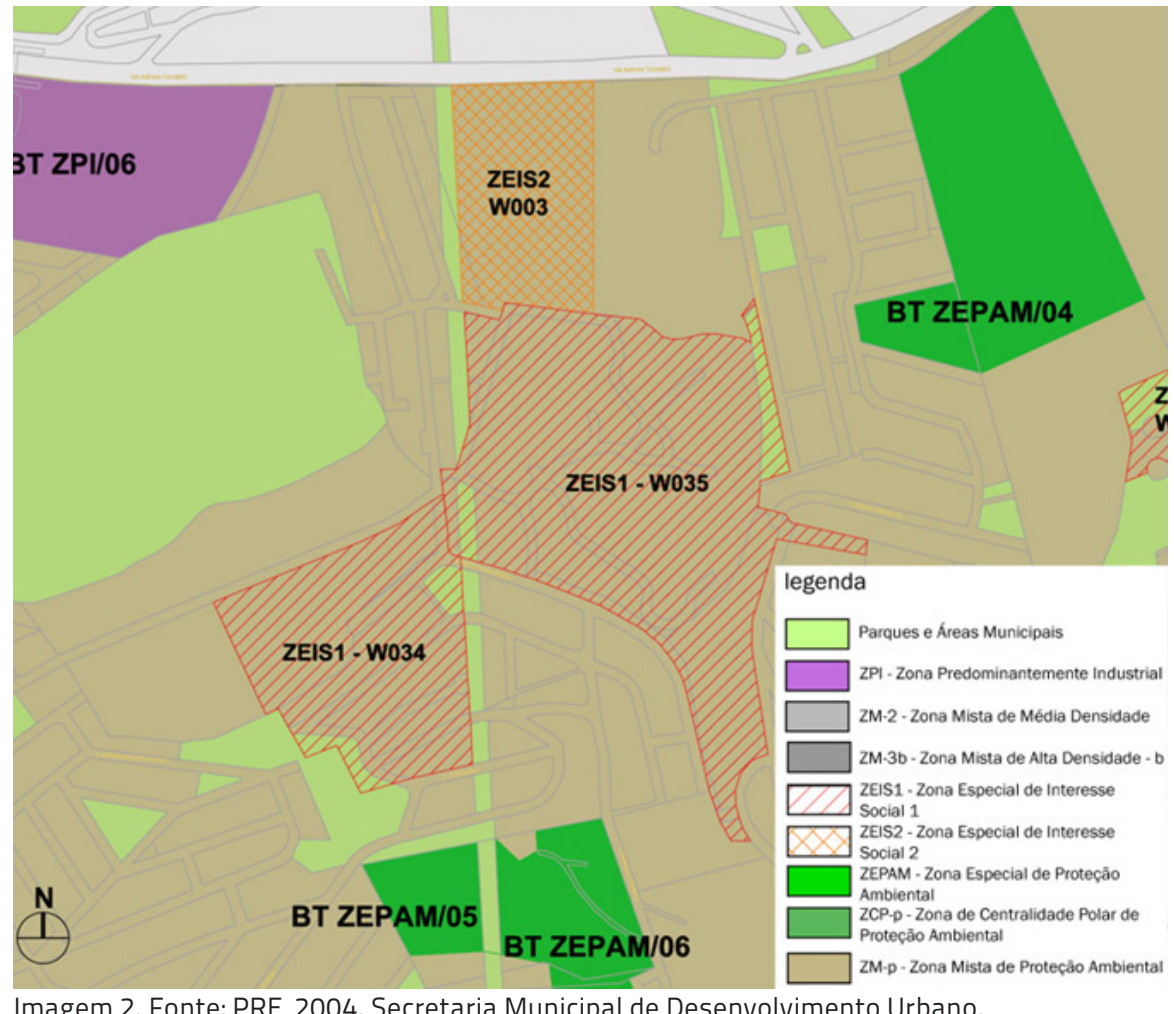

Imagem 2. Fonte: PRE, 2004. Secretaria Municipal de Desenvolvimento Urbano.
10 Zoneamento do município faz parte do Plano Diretor Estratégico do Município de São Paulo (PDE) - Lei n 13.430/2002 e do Plano Regional Estratégico de cada Subprefeitura (PRE) - Lei $n^{\circ}$

$13.855 / 2004$. 
intermunicipais, tendo como destinos principais o centro e o bairro de Pinheiros. As principais vias de acesso direto para a favela são as Ruas Sebastião Gonçalves e Alessandro Bibiena, servidas por transporte público, e a Avenida das Olarias, primeira rua da ocupação, onde se localizavam as antigas olarias, e que hoje pode ser considerada como a principal rua interna à favela, que interliga as principais vias de circulação do Jardim Jaqueline.

De acordo com informações da Defensoria Pública do Estado de São Paulo (DPESP), o Jardim Jaqueline possui área de 134.442,89 m² e 3.392 domicílios. As redes de energia elétrica e de água são oficiais, com exceção das áreas de ocupação recente, localizadas em grande parte sobre as APPs. A rede oficial de esgoto passa pela Rua Sebastião Gonçalves e Avenida das Olarias. No restante da área, a rede foi executada pelos moradores.

\subsection{MEIO BIOFÍSICO E INFRAESTRUTURA LOCAL}

\subsubsection{MEIO BIOFÍSICO}

Os cursos d'água que passam no Jardim Jaqueline são tributários da bacia do Rio Pirajussara, e estão localizados em uma região de diferentes padrões de uso e ocupação do solo, onde as ocupações irregulares das favelas se somam a ocupações regulares no processo de degradação das Áreas de Preservação Permanentes. Os moradores do Jardim Jaqueline ocuparam o curso dos córregos, enquanto o Shopping Raposo e um condomínio residencial regular ocuparam suas nascentes. Assim como no restante da cidade, o exemplo de ocupação desses cursos d'água é a prova cabal de que a responsabilidade pela degradação dos recursos naturais no urbano é solidária, sendo que poderíamos atribuir maiores responsabilidades em relação aos processos de ocupação formais, que teoricamente passaram por projetos e aprovações do poder público. Em relação a esse fato, podemos nos debruçar em um longo debate sobre a

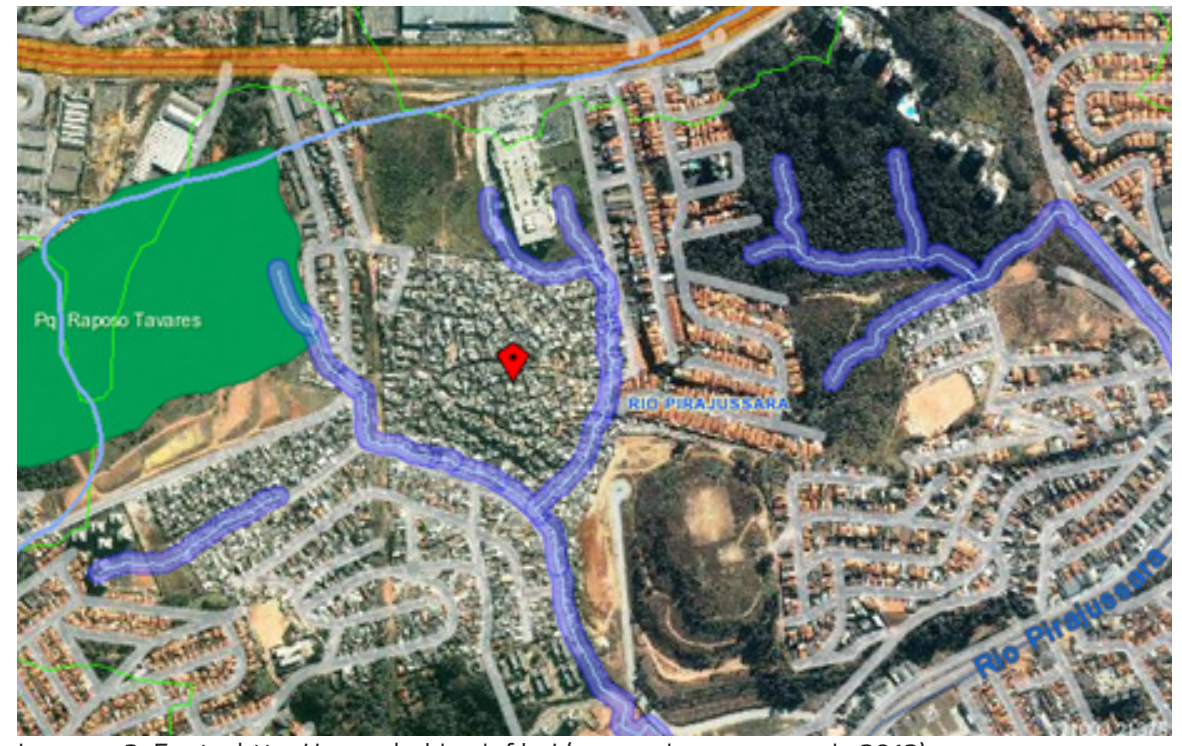

magem 3. Fonte: http://www.habisp.inf.br/ (acessado em março de 2012)

2 A área mais precária do Jardim Jaqueline é conhecida como CIT, nome da empresa proprietária do lote.

3 Relatório Técnico do IPT n 119.708-205. 0 estudo do Instituto de Pesquisa Tecnológicas (IPT), que englobou "análise e mapeamento de riscos associados a escorregamentos em áreas de encostas e a solapamentos de margens de córregos", foi encomendado pela prefeitura de São Paulo $A$ metodologia de mapeamento subdivide as áreas de risco em quatro categorias de possibilidade de ocorrência de eventos em situações de chuva intensa e/ou prolongada: risco baixo (R1), não se espera a ocorrência de acidentes; médio (R2), é reduzida a possibilidade de ocorrência de acidentes; alto (R3), é possivel a ocorrência de acidentes; e muito alto (R4), é muito provável a ocorrência de acidentes. As áreas críticas, enquadradas entre as de risco alto e muito alto são prioritárias para intervenções de redução de risco e programas de reassentamentos (ou remoções). 


\section{LEGENDA}

- Rios Principais

- Corregos

- Divisor de Sub-Bacias

Piscinões existentes

FONTE SEMPLA-ATOU
SEMPLA-DIPRO

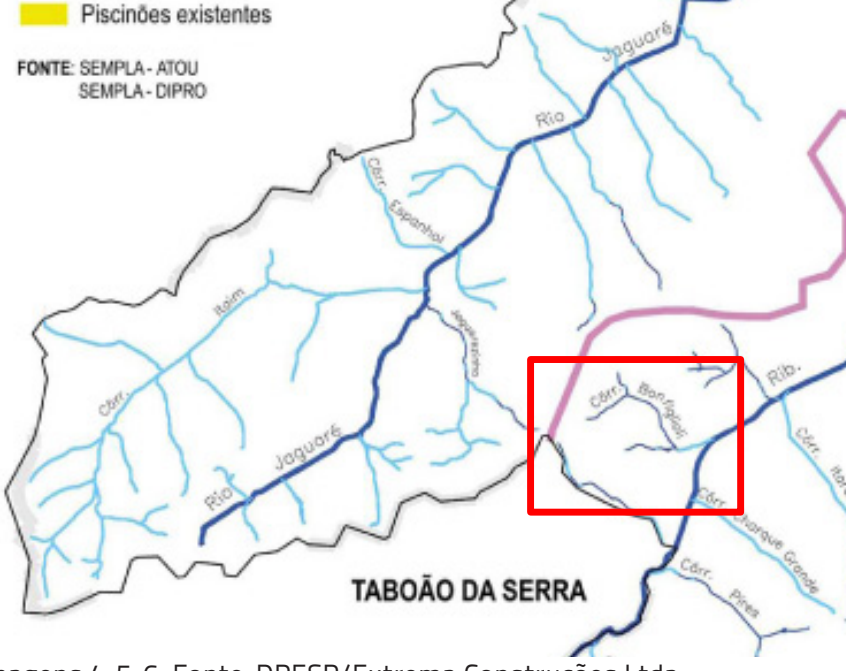

Imagens 4, 5, 6. Fonte: DPESP/Extrema Construções Ltda.

degradação por opção ou pela falta de opção e sobre as práticas e discursos que legitimam a degradação oficial, em detrimento da ideologia da "revitalização" e do "saneamento" que associa degradação a pobreza.

Os cursos d'água, que seguem tamponados desde suas nascentes, passam pelas principais ruas da favela - as supracitadas Sebastião Gonçalves e Alessandro Bibiena - se encontrando na área da $\mathrm{CIT}^{2}$, área mais precária da favela, quando continuam o percurso a céu aberto. Algumas áreas da CIT são consideradas como áreas de risco pelo estudo do instituto de Pesquisas Tecnológicas (IPT) de 2010³, em relação ao solapamento das margens dos cursos d'água e escorregamento de encostas. As poucas residências de madeira do Jardim Jaqueline estão localizadas nessa área, sendo que algumas foram construídas sobre o córrego, em palafitas.
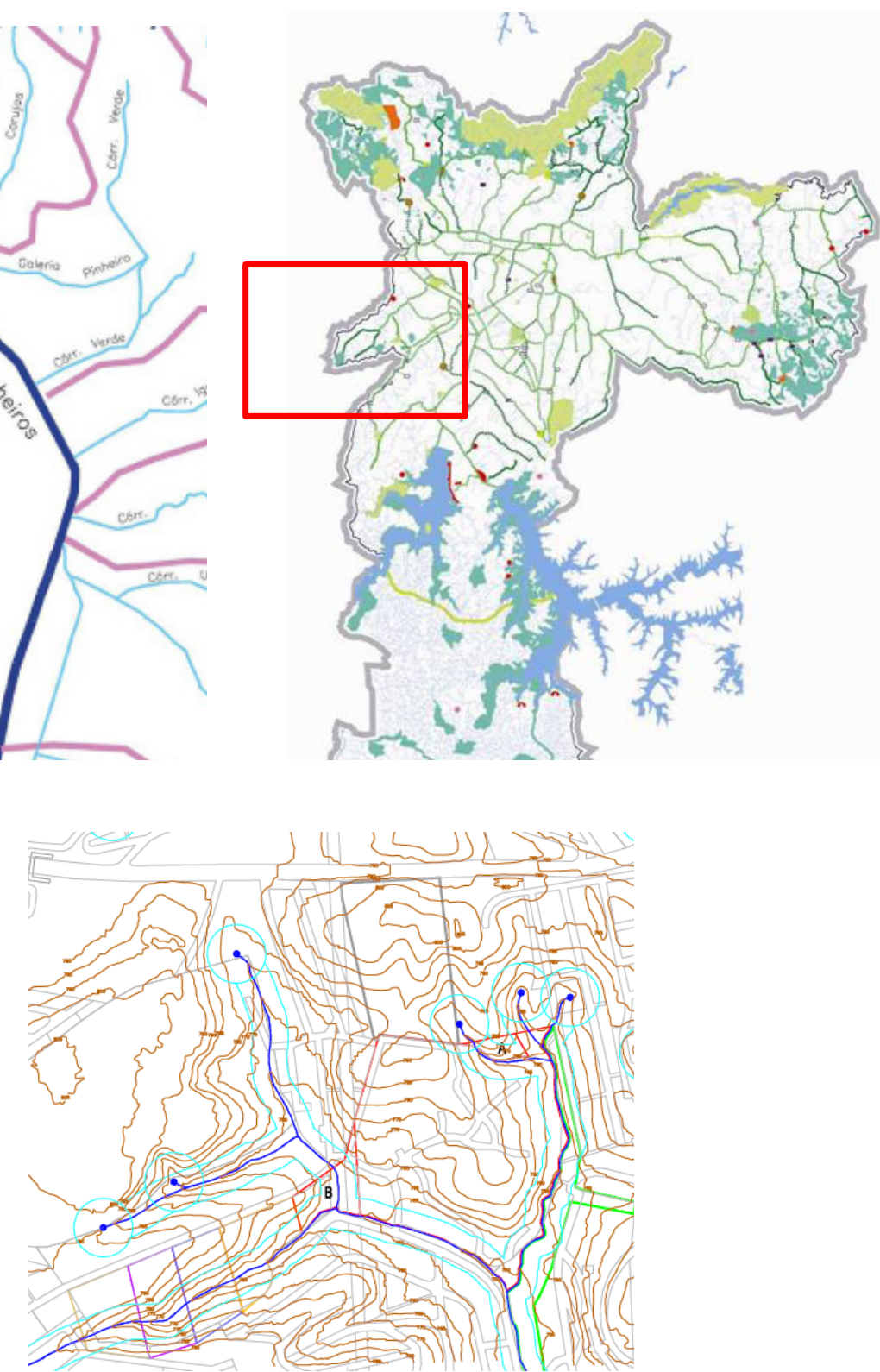
De acordo com o relatório foram identificadas áreas de risco R2 (médio), e como medidas de resolução do problema foram indicados: serviços de limpeza de lixo e entulho; serviços de limpeza no sistema de drenagem (águas pluviais, servidas e/ou esgoto); limpeza (desassoreamento, lixo, entulho) do canal de drenagem; manutenção nas obras já realizadas; execução de sistema de drenagem superficial de topo e base no talude (águas pluviais, servidas e/ ou esgoto); de sistemas de drenagem superficial (águas pluviais, servidas e/ ou esgoto); e melhoria nos acessos (calçadas, escadarias, ruas) integrandoos com o sistema de drenagem. Tais indicações, comuns a todas as áreas de nivel semelhante de risco, não levam em conta nenhum condicionante diverso do geológico, não considerando sequer alagamentos causados pelas chuvas. O mapeamento de áreas de risco vem sendo usado pela prefeitura municipal para remoção de assentamentos de baixa renda, em locais identificados como de risco R3 e R4, indiscriminadamente, sem garantias de moradia definitiva às famílias removidas. 0 processo de instrumentalização das chamadas áreas de risco por parte da prefeitura de São Paulo, principalmente em relação à última gestão, que utilizou intensamente a metodologia adotada pelo IPT para remover assentamentos de baixa renda, merece pesquisa independente. Cabe registrar que os relatórios apresentados pelo IPT raramente sugerem remoções de moradores nas áreas de risco e quando o fazem, as construções são individualizadas e devidamente localizadas.

Para a caracterização geológica e geotécnica da área, a empresa contratada pela Defensoria Pública contou com a consultoria do geólogo Álvaro Rodrigues dos Santos, que realizou vistoria técnica na favela no dia 3 de agosto
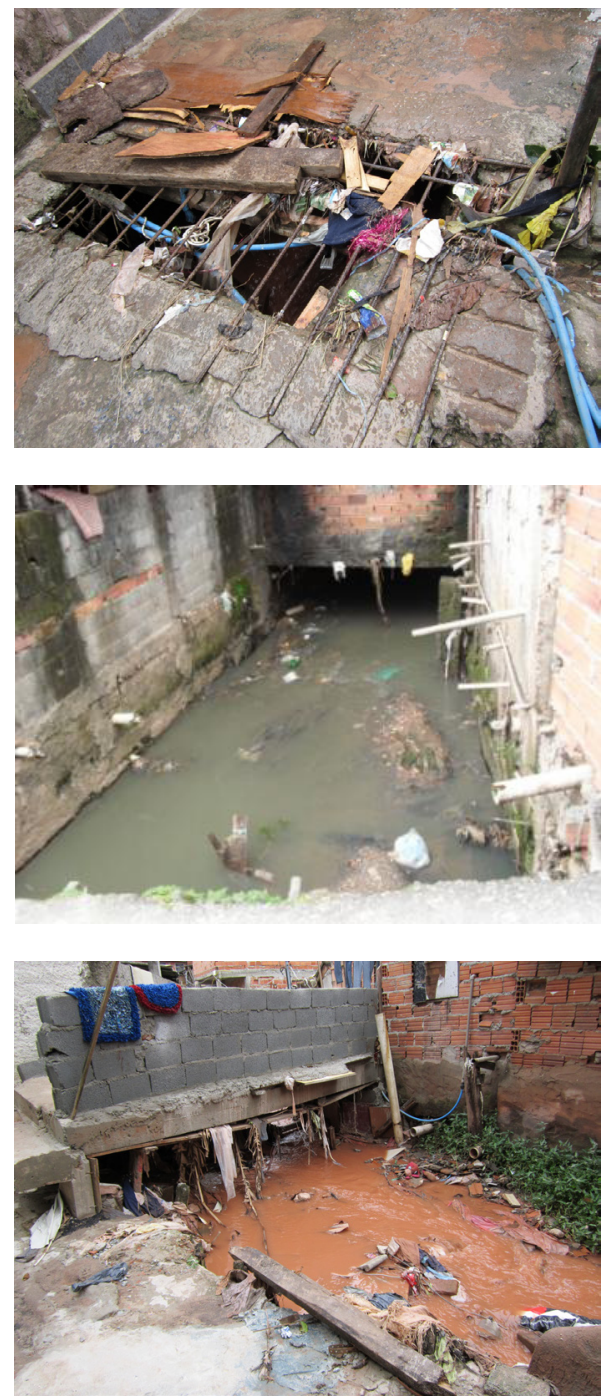

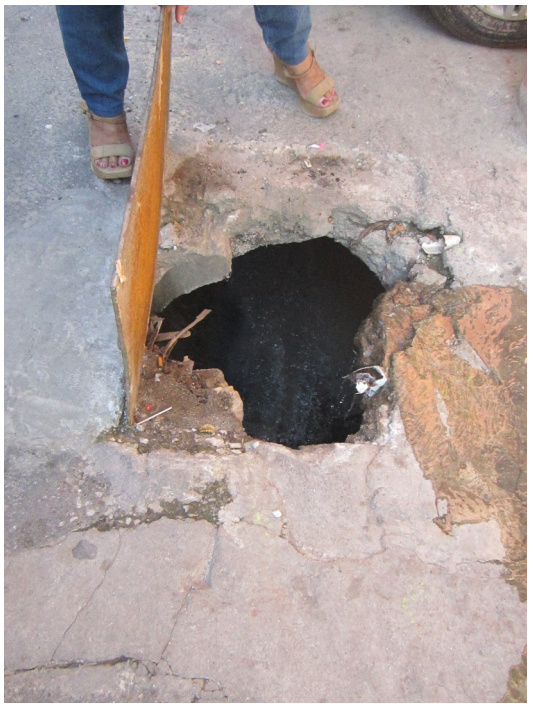

Imagens 7, 8, 9. Imagens de situações encontradas nas áreas de risco de 2011. As observações apontadas pelo geólogo seguem transcritas a seguir: 
1) Do ponto de vista geológico e geotécnico a área não apresenta riscos de deslizamentos:

2) Os maiores riscos físicos são de origem hidráulica e estão associados à possibilidade de solapamento das margens do curso d'água que corta o bairro e à avaria de fundações das edificações que estão instaladas sobre o próprio canal dessa drenagem;

3) Especialmente a parte mais alta do Jardim Jaqueline está assentada sobre uma região de nascentes de água, pelo que o córrego local, em pleno inverno pouco chuvoso, aumenta em muito sua vazão à medida que seu curso avança para as áreas mais baixas; 4) Há áreas de edificações extremamente precárias ao longo da calha do córrego, onde são bem maiores os riscos de avarias às frágeis fundações de madeira com real possibilidade de acidentes graves;

5) A condição sanitária geral do bairro é de extrema precariedade com esgotos lançados diretamente no sistema natural e construído de drenagem. A ponto de poder-se afirmar que os riscos à saúde pública por esse vetor sanitário são muito mais graves que os riscos de ordem hidráulica e de ordem geológica;

6) Com a progressão rápida da impermeabilização da área a montante do bairro haverá um grande incremento do volume de águas de chuva que afluirão para o interior do bairro, o que sobrecarregará mais ainda seu já totalmente insuficiente sistema de drenagem, o que significará um adicional considerável ao nível dos riscos hidráulicos e sanitários hoje já presentes;

7) Foi constatada uma infiltração de águas de esgoto na base do muro de arrimo que separa a parte alta do bairro da área ocupada pelo Shopping Raposo. Essas águas contaminadas são provavelmente provenientes de vazamentos da estação de tratamento primário de esgoto do próprio Shopping situada exatamente do lado montante do referido muro.

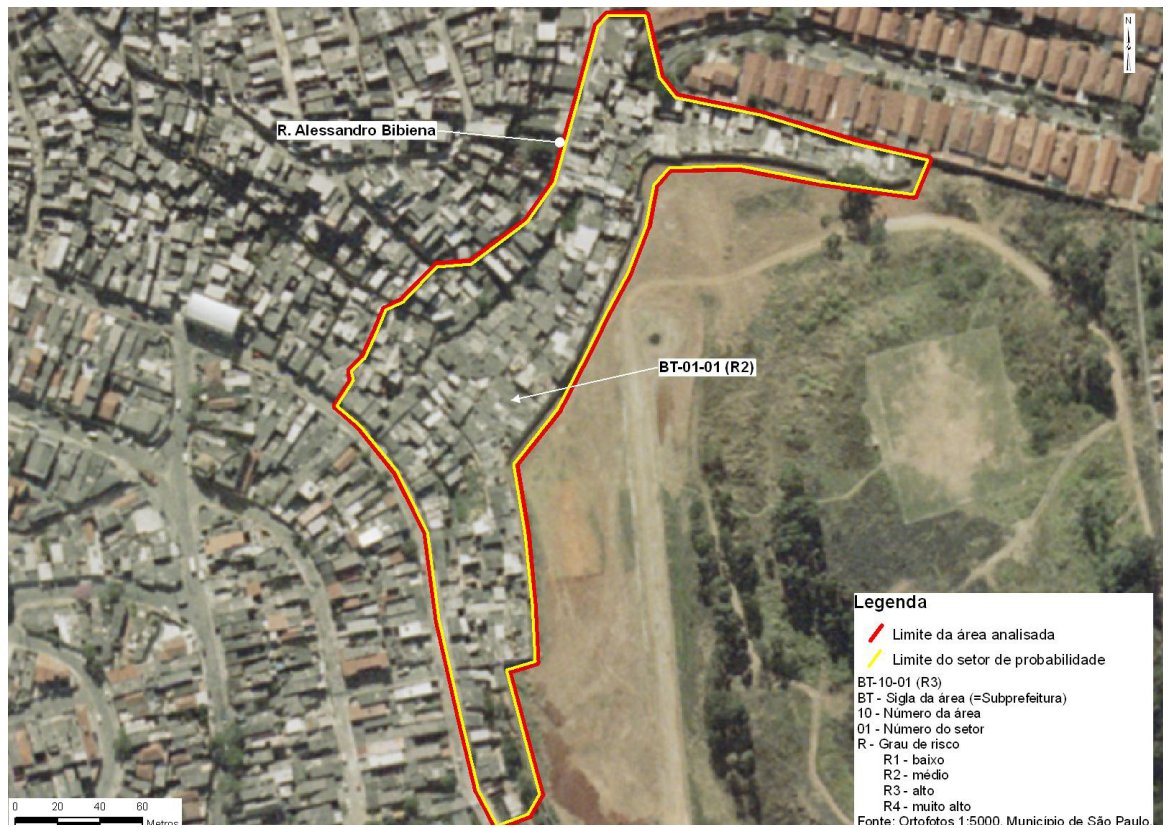

magem 11. Fonte: Relatório Técnico IPT N¹19.708-205-37/303, foto FV-BT-01 
2) Há necessidade urgente de elaboração e implantação de Projeto de Drenagem e de Projeto de Saneamento, áreas às quais estão associados os principais riscos à população;

3) É por tudo recomendável a remoção temporária dos moradores das áreas com predominância de edificações mais precárias (barracos) existentes ao longo do córrego até que sejam erguidas no local ou em outros locais do bairro edificações de melhor qualidade que os possam abrigar com um mínimo de segurança e dignidade;

4) Como medida primária e emergencial voltada a aumentar a capacidade de vazão das drenagens internas ao bairro, reduzindose assim o risco de inundações localizadas, recomenda-se um trabalho de completa limpeza dessas drenagens com retirada do lixo e entulho acumulados. No âmbito dessa mesma ação é recomendável um melhor equacionamento do sistema de coleta e descarte do lixo doméstico.

Nota-se que a análise é mais ampla do que a efetuada pelo IPT, com a consideração das implicações decorrentes da estrutura das edificações, da infraestrutura instalada e da impermeabilização da área, bem como da questão sanitária. Alguns pontos do parecer geológico e geotécnico da área podem ser destacados, como a falta de necessidade de grandes projetos de estabilização e contenção de encostas, que geralmente justificam processos de remoção de populações de baixa renda. É apontada como urgente a necessidade de projetos de drenagem e saneamento básico, sendo que, os principais riscos registrados pelo geólogo não dizem respeito à estabilidade geotécnica, mas às condições sanitárias a que estão submetidos os moradores, com graves consequências à saúde pública.

Também chama atenção a infiltração de água de esgoto no muro que separa a favela do Shopping, provavelmente decorrente de vazamentos da estação de tratamento primário de esgoto do próprio empreendimento. Tal muralha, construída de forma tortuosa, ocupa parte da gleba de posse do Jardim Jaqueline, fazendo com que a suposta área regular, com aval ou não do proprietário da gleba, esteja em parte na mesma condição jurídica dos moradores do Jardim Jaqueline, de 'invasores". Parte desse muro caiu recentemente, pela força das chuvas, desalojando cerca de 20 famílias de suas residências. 0 acidente, felizmente sem vítimas, teve pouca repercussão, já que o Shopping pagou estadia em hotel para todos os moradores desalojados, até que o problema fosse resolvido. A referida estação de tratamento primário de esgoto do Shopping está localizada na área onde os mapas acusam as nascentes dos cursos d'água.

É importante frisar o caráter abrangente de um parecer técnico realizado por profissional que comumente é
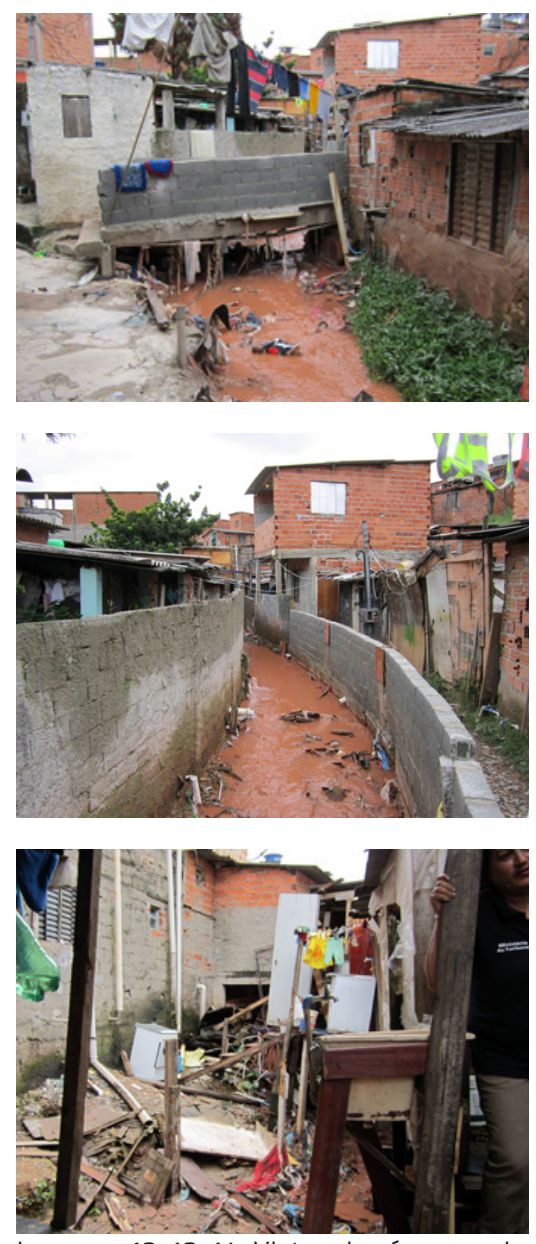

Imagens 12,13, 14. Vistas das áreas onde o córrego permanece aberto 
colocado como pertencente a um universo técnico científico do conhecimento que dispensa a dimensão humana envolvida nos "fatos técnicos". Dos engenheiros, geólogos, e tecnólogos de diversas especificidades, é esperado o conhecimento técnico "isento", que sentencia a questão colocada de acordo com parâmetros técnicos "inquestionáveis". Estamos vivenciando uma época em que esse tipo de conhecimento "isento" é muito valorizado, com diversas linhas de especializações, que se afastam cada vez mais da real dimensão da vida, em que o ser humano é parte do meio ambiente. Quando o técnico geólogo coloca a questão em sua real dimensão, que diz respeito à dignidade dos habitantes daquele substrato, está valorizando não somente a dimensão humana da paisagem, mas também a sua atuação profissional.

\subsubsection{MORFOLOGIA E INFRAESTRUTURA LOCAL}

O principal meio de deslocamento dos moradores é o transporte coletivo, com a utilização das linhas de ônibus e lotações que levam ao centro ou ao bairro de Pinheiros. Os deslocamentos a pé também são significativos, realizados principalmente nas ruas principais, em direção aos equipamentos públicos e pontos de ônibus. O diagnóstico urbanístico realizado para o processo de regularização fundiária verificou que os maiores fluxos se dão dos locais de moradia para fora da favela, revelando que existe pouca mobilidade dos moradores dentro da favela. Quando essa mobilidade existe, foram apontadas grandes dificuldades em se transitar pelas ruas e vielas, pela ausência de calçadas e ruas estreitas, que tornam o trânsito dos pedestres perigoso, em decorrência do conflito de uso com motos e carros. Constatou-se que o cotidiano dos moradores se concentra nos setores específicos onde moram. Dado importante que pode ser visto em uma das reuniões com os moradores é a falta de contato entre os setores mais consolidados da favela e o setor denominado CIT, tido como perigoso pelos

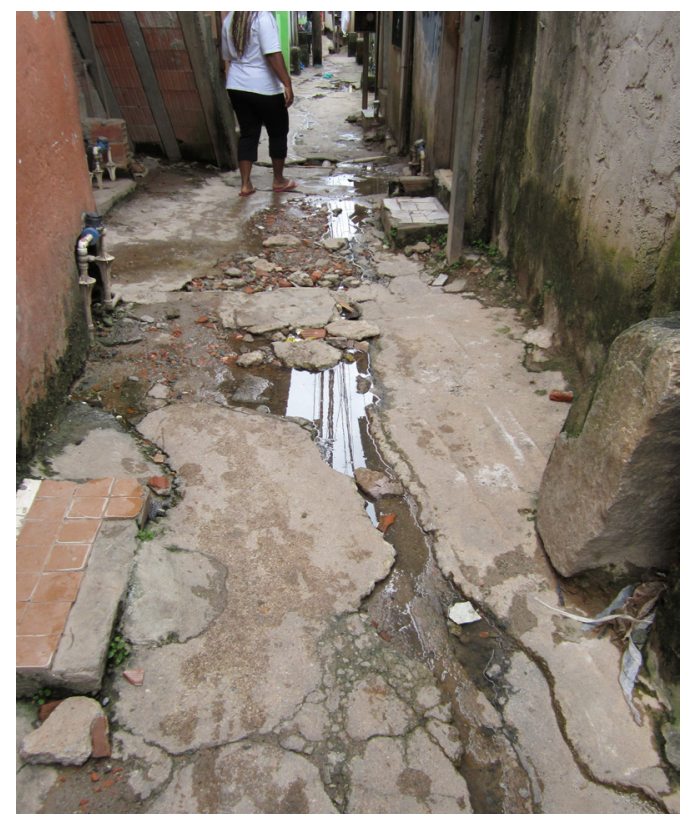

magem 15. Esgoto nas vielas indica

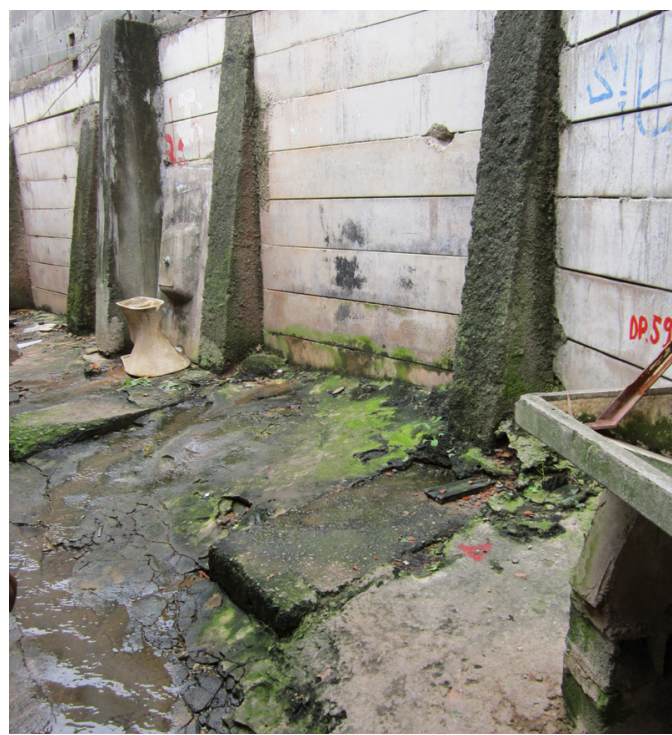

16. Infiltração proveniente

da estação de tratamento de esgoto, em muro construído pelo Shopping 
moradores residentes em outras áreas. Da mesma forma, a liderança dos moradores, Sra. Elisabete Silva, considera que os moradores da CIT são os que mais prezam os trabalhos realizados pela Associação de Moradores, por ser a parcela da população local que mais precisa das doações e projetos sociais por ela promovidos. Esse tipo de apreensão dos moradores em relação ao lugar é muito importante para o entendimento das dinâmicas internas da favela, que, a principio, poderia ser considerada como uma unidade morfológica e social homogênea.

Praticamente todas as vias de acesso do Jardim Jaqueline estão impermeabilizadas, apesar do péssimo estado de conservação verificado em grande parte delas, principalmente as localizadas na CIT e sobre as APPs. Calçadas são encontradas somente nas ruas Sebastião Gonçalves, Alessandro Bibiena e Joaquim Alves, por onde passam os ônibus e lotações. O conflito entre os pedestres e todas as formas de transporte motorizado pode ser visto no acesso da Rua Sebastião Gonçalves para a Rua das Olarias, sem calçada e estreita, por onde passam vans escolares, caminhões com materiais de construção, o caminhão do lixo e todos os veículos que abastecem o comércio local, além das motos que transitam em alta velocidade. A Rua das Olarias pode ser considerada a principal via interna do assentamento. Com cerca de cinco metros de largura, concentra grande fluxo de pedestres e veículos motorizados, além de dividir espaço com estacionamento de veículos e caçambas de lixo.

Parte das ligações de água, luz e esgoto são oficiais, como poderá ser visto na análise socioeconômica, e a coleta de lixo é realizada regularmente, apesar do excesso de lixo visto nas ruas com frequência. De acordo com diagnóstico urbanístico do processo de regularização fundiária realizado por empresa contratada pela Defensoria Pública, o esgoto oficial coletado liga-se ao coletor tronco do Pirajussara e segue a ETE Barueri (Estação de Tratamento de Esgoto). Parte das residências efetuou ligações clandestinas à rede e outras, principalmente na área da CIT, jogam o esgoto diretamente no córrego.

\subsection{CARACTERIZAÇÃO SOCIOECONÔMICA}

A ocupação do Jardim Jaqueline teve início na década de 1960. De acordo com dados do município, disponíveis em sua base de dados (HABISP4), em 2000, existiam aproximadamente 1.300 moradias no local. A renda média era de R\$ 600,00 e cerca de $70 \%$ da população tinha renda inferior a três salários mínimos. Dos dados oficiais de 2000 até os dados levantados pela Defensoria Pública do Estado de São Paulo, os números mais que dobraram, com a estimativa atual de 2.867 famílias vivendo no local, em um total de 3.392 domicílios identificados. A caracterização socioeconômica do local será realizada por meio da comparação entre o diagnóstico socioeconômico realizado pela empresa contratada pela Defensoria Pública

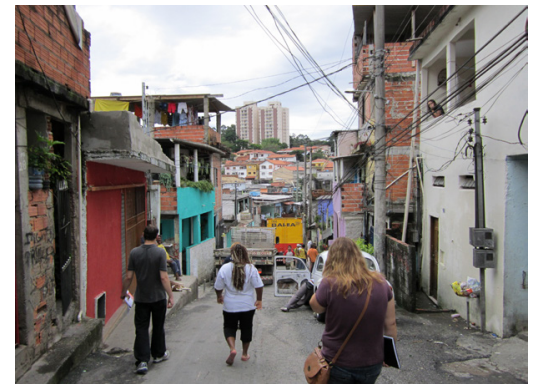

Imagem 17. Vista da Rua das Olarias com evidências do conflito diário entre a circulação de pedestres, carros, caminhões, motos

4 Os dados oficiais, acessados em 2010, fazem parte do Plano de Referência do projeto de regularização fundiária do Jardim Jaqueline, executado pela Defensoria Pública do Estado de São Paulo. Recentemente a base de dados do município foi atualizada, com números que coincidem com os levantamentos já executados por empresa contratada pela Defensoria Pública. Disponivel em: <http://www. habisp.inf.br/busca?q=jardim+jaqueline>. Acesso em: 21 Jan. 2012.

5 As informações foram colhidas entre abril de 2011 e fevereiro de 2012, período em que a empresa contratada pela Defensoria Pública e esteve diariamente em campo executando os trabalhos de selagem e cadastro dos domicílios, além dos trabalhos técnicos de levantamento planialtimétrico, planta de parcelamento e memoriais descritivos dos lotes individualizados. Todos, nos índices relacionados ao Jardim Jaqueline, pertencem ao Diagnóstico Socioeconômico realizado no âmbito deste trabalho. Composição dos domicílios: total, 3.344; residenciais, 2.867; comerciais, 168 ; ausentes, recusas e vazios, 309 . 
para realização dos trabalhos técnicos para a regularização fundiária, os dados do Instituto Brasileiro de Geografia e Estatística (IBGE), os da Fundação SEADE e os do Centro de Estudos da Metrópole (CEM). Além dos dados oficiais da região metropolitana de São Paulo, alguns dados coletados no Jardim Jaqueline serão comparados às pesquisas de Pedro Abramo sobre o mercado informal do solo e a mobilidade residencial em assentamentos populares, realizadas em favelas de grandes metrópoles brasileiras. Tal comparação se deve à aproximação encontrada entre a referida pesquisa e os dados coletados no Jardim Jaqueline, que indicam padrões similares de mobilidade urbana de favelas de diversas regiões metropolitanas.

A pesquisa de Eduardo Marques se refere aos anos de 1991 e 2000, traçando a evolução das favelas em São Paulo desde a década de 1970. 0 trabalho da equipe de Pedro Abramo foi publicado em 2006 e o diagnóstico socioeconômico elaborado para o processo de regularização fundiária do Jardim Jaqueline foi finalizado em $2012^{5}$. O Jardim Jaqueline foi dividido em quatro setores, com características morfológicas similares, para efeitos de levantamento de informações e organização dos moradores, de acordo com mapa indicado. Para cada setor foram mobilizados todos os moradores para realização dos cadastros socioeconômicos e participação em reuniões de capacitação em relação ao processo de regularização fundiária e escolha de representantes, que passaram a compor um fórum de moradores, potencial embrião do futuro conselho gestor da ZEIS do Jardim Jaqueline.

1.3.1. RESUltado do levantamento Quantitativo: QUEM SÃo OS MORADORES DO JARDIM JAQUELINE?

De acordo com o resultado dos cadastros, a média de idade dos moradores é de 25 anos e oito meses, revelando uma expressiva quantidade de jovens, fato
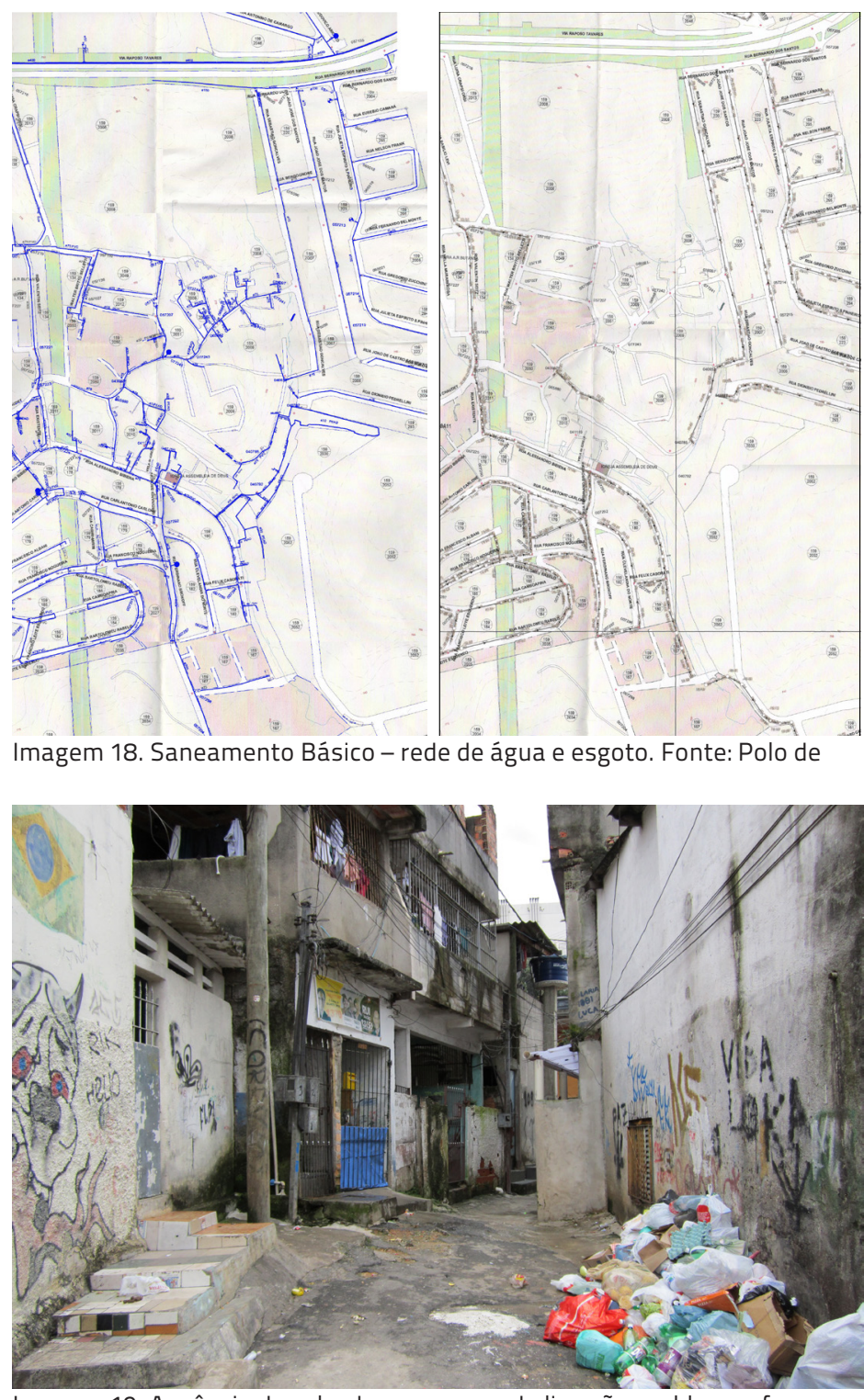

Imagem 19. Ausência de calçadas e excesso de lixo são problemas frequentemente apontados pelos moradores 
que pode ser comprovado nas diversas passagens pelas ruas e vielas da favela, sempre repletas de crianças e bebês de colo. 0 grande número de crianças que podem ser vistas nas ruas, comparado à atividade do tráfico de drogas, que conta com grande presença de jovens em idade escolar, indica a vulnerabilidade a que esses jovens estão submetidos. A estrutura etária apresentada, aliada aos índices de escolaridade, expressos nos gráficos, dá a dimensão da questão social a ser enfrentada.

Além das altas taxas de analfabetismo encontradas na faixa etária acima de 60 anos, chama atenção a quantidade de jovens entre 18 e 21 anos que não completaram o ensino médio (73\%) e o baixo acesso ao ensino superior em todas as faixas etárias.

A renda per capita da população é de $\mathrm{R} \$ 428,81$, sendo que a renda média verificada entre os que possuem rendimentos é de $\mathrm{R} \$ 787,45$. Cerca de $60 \%$ da população acima de dez anos está empregada, dos quais $72 \%$ trabalham em outro bairro, 16\% no próprio bairro, 3\% em outro município, 2\% no próprio domicilio e 5\% não têm um local fixo de trabalho. Foram identificados 168 estabelecimentos comerciais e 63\% deles não possuem CNPJ, indicando que as relações comerciais são caracterizadas pela informalidade. Grande parte do comércio local é relacionada a alimentação e pequenas vendas sem especificação. Também encontramos salões de beleza, instituições religiosas, oficinas mecânicas, conserto de aparelhos domésticos e um depósito de materiais recicláveis. Esses comércios representam a principal fonte de renda para a maioria das famílias que administram o negócio (55\%).

Nesse ponto, podemos associar os dados da informalidade nas relações de consumo com a análise de Pedro Abramo a respeito das vantagens locacionais em relação às favelas. O pesquisador aponta como "externalidade positiva" em relação às favelas as economias de reciprocidades entre a comunidade, que

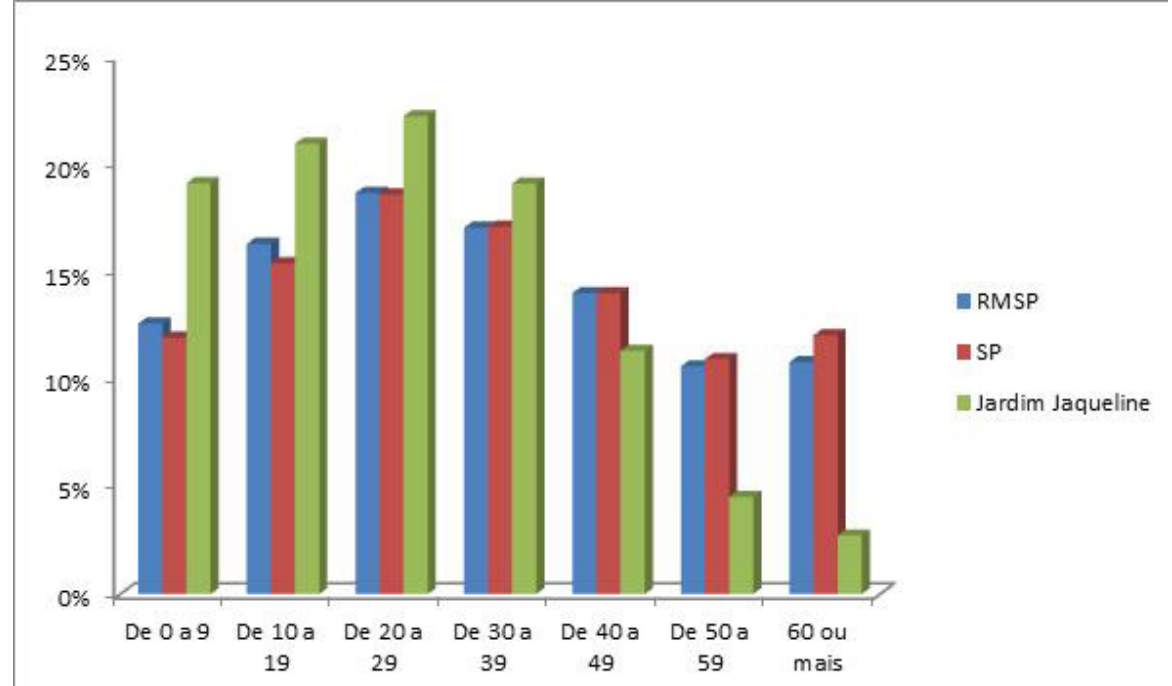

Gráfico 1: População segundo faixa etária

Fonte: Pesquisa Censitária Socioeconômica/2012. DPESP/Extrema Construções Ltda.

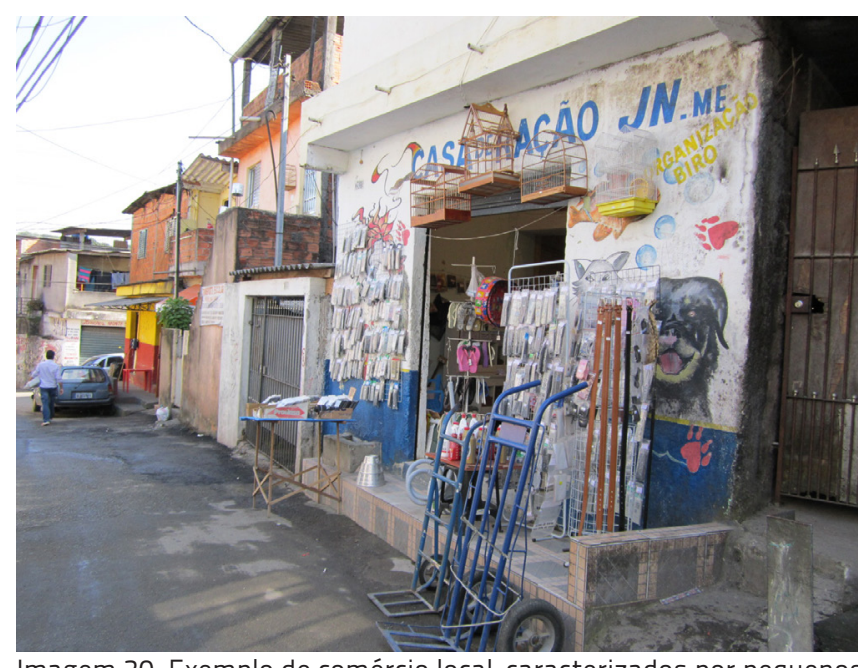

Imagem 20. Exemplo de comércio local, caracterizados por pequenos espaços repletos de produtos, em grande variedade 


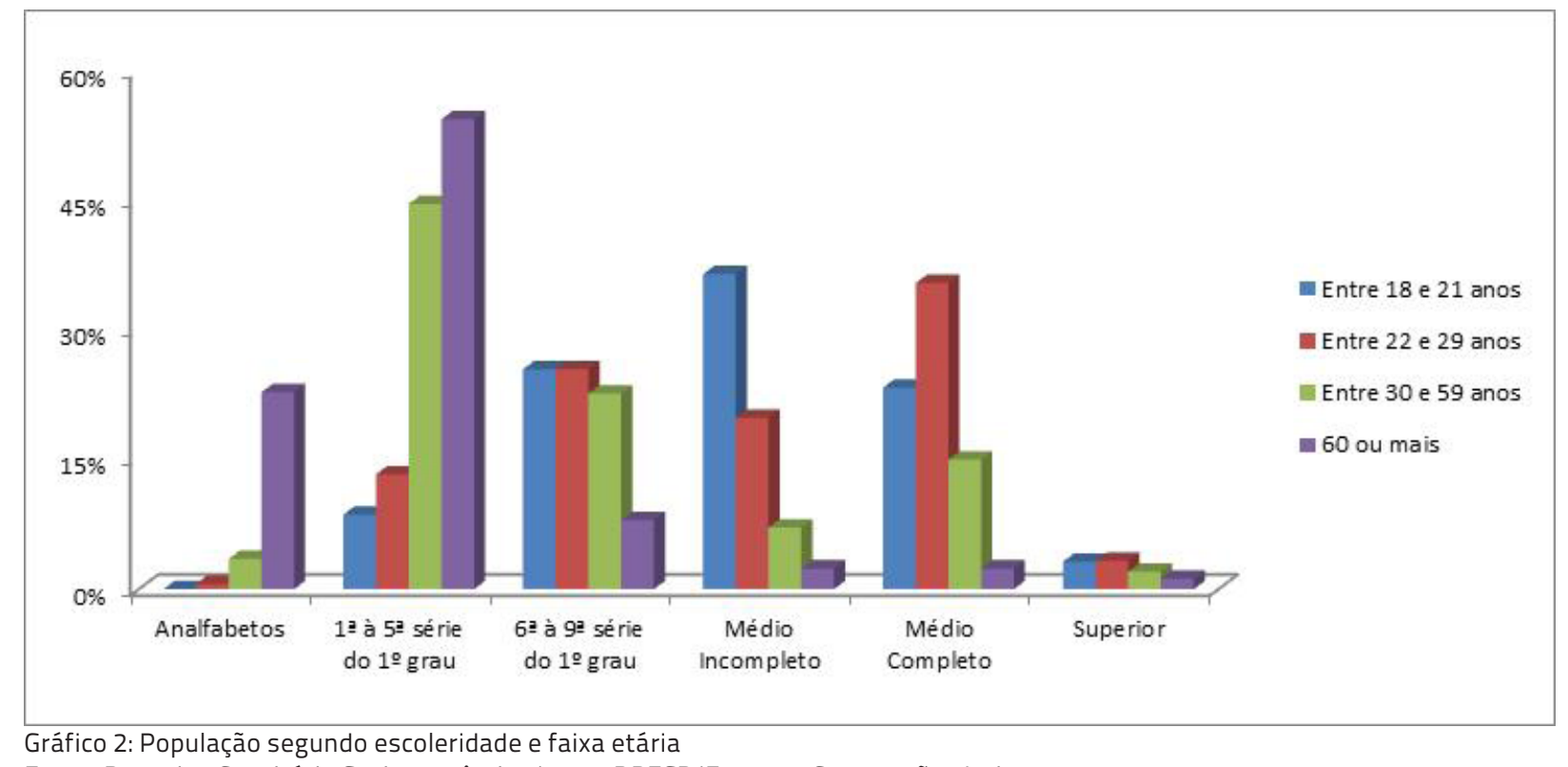

Fonte: Pesquisa Censitária Socioeconômica/2012. DPESP/Extrema Construções Ltda.

seriam as trocas e acesso a bens de serviço de forma não monetária, que faria com que os moradores de favelas tivessem um rendimento real maior que o monetário. Não se trata aqui de apologia às formas de escambo dentro de uma metrópole onde o dinheiro representa o acesso à cidade, mas a constatação de que os moradores de favelas encontram formas de sobrevivência em contextos de precariedade e que esses padrões de sociabilidade devem ser considerados em qualquer projeto de urbanização ou de deslocamentos de populações de baixa renda. Em diversas ocasiões, técnicos que realizaram levantamentos de campo para o processo de regularização fundiária para fins de moradia foram questionados a respeito do encaminhamento dado aos estabelecimentos comerciais, já que muitas famílias sobrevivem de seus rendimentos.

O levantamento realizado no Jardim Jaqueline questiona novamente o mito da marginalidade do favelado, que, assim como constatou a pesquisadora Janice Perlman em 1976, se encontra social e economicamente integrado à cidade e à economia urbana (BUENO, 2000: 170). Apesar de toda a base científica reunida a respeito do mundo do trabalho dos habitantes da favela, ainda é senso comum que os moradores das favelas trabalham menos ou passam grande parte do dia 


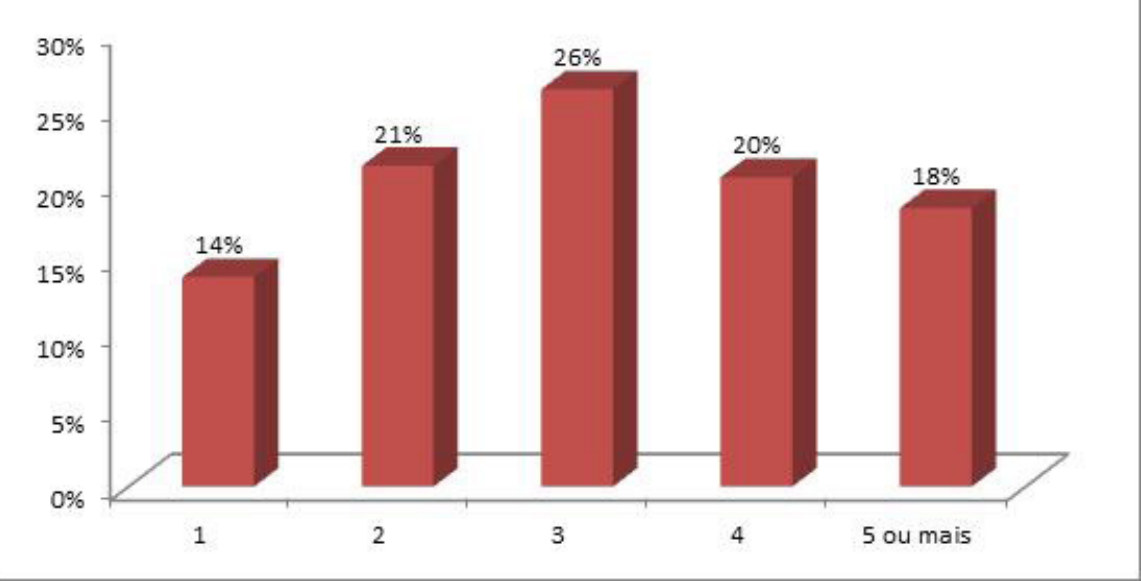

Gráfico 3: Domicílios segundo o número de pessoas residentes

Fonte: Pesquisa Censitária Socioeconômica/2012. DPESP/Extrema Construções Ltda.

nos bares. Falas genéricas nesse sentido são usuais, seguidas de complementos como "[...] mas também tem muita gente trabalhadora".

Foram identificados 2.867 domicílios de uso residencial, com 9.281 pessoas cadastradas. A média de moradores por domicílio é de 3,26, de acordo com a distribuição expressa pelo gráfico.

De acordo com a pesquisa do CEM para o município de São Paulo, a densidade domiciliar média nas favelas caiu de 4,59 moradores por domicílio em 1991 para 3,97 em 2000, seguindo a tendência de queda do conjunto do município, no qual as densidades foram de 3,80 e 3,46 habitantes por domicílio para as duas datas censitárias, respectivamente. 0 Censo de 2010 indica 3,15 habitantes por domicílio, mantendo-se a tendência de queda. Mesmo em relação a esse contexto, foram encontrados domicílios com até 12 habitantes, no setor 4 , conhecido como CIT, área de ocupação mais recente e precária. A diminuição da densidade por domicílio pode estar relacionada à diminuição do número de cômodos nas

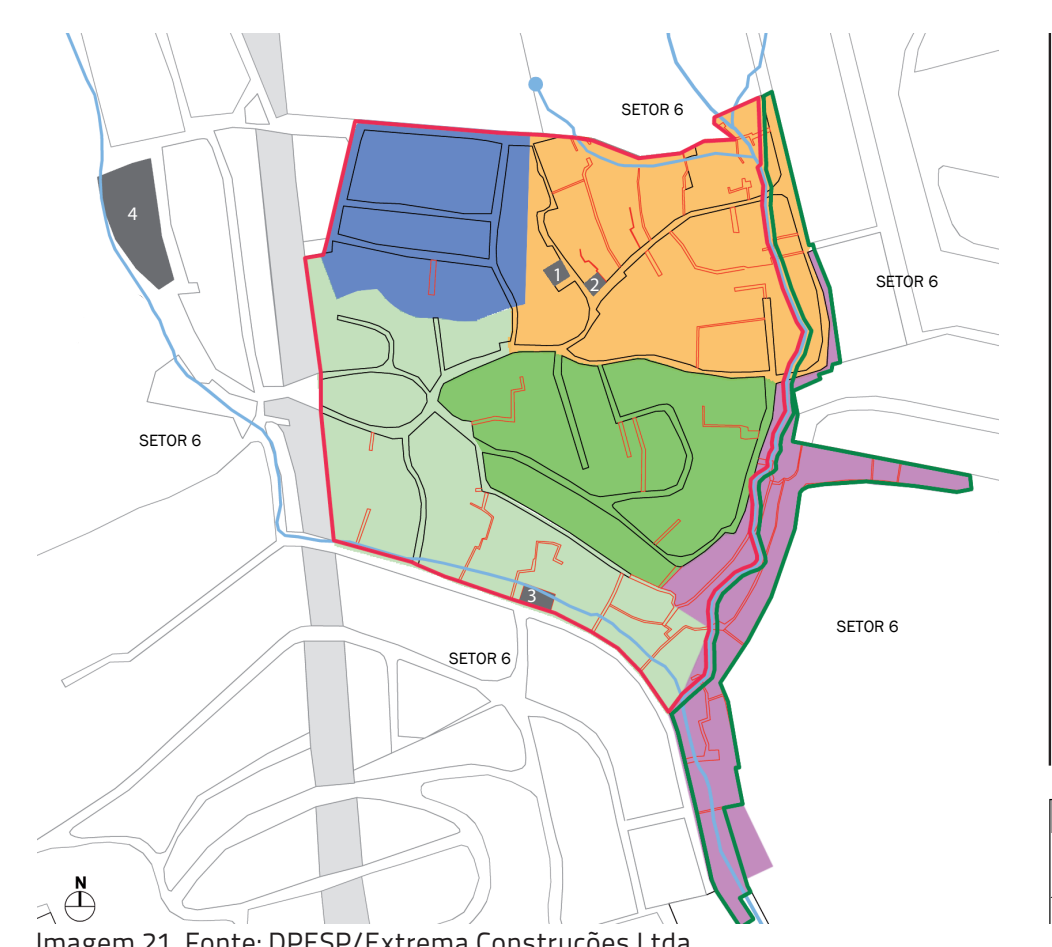

Imagem 21. Fonte: DPESP/Extrema Construções Ltda.

\section{legenda}

-Demarcaçōes

\begin{tabular}{|c|c|c|c|}
\hline & Matrícula 49.609 & & \\
\hline & Área de ZEIS fora do perímetro da & & \\
\hline - Sistem & $\begin{array}{l}\text { Matrícula } \\
\text { a viário }\end{array}$ & & \\
\hline & Ruas & - Macros & \\
\hline & Vielas e corredores & ouro & Setor 1 \\
\hline & cia locais & & Setor 2 \\
\hline & Córrego cadastrado & & Setor 3 \\
\hline & Rede de trasmição elétrica & & Setor 4 \\
\hline & $\begin{array}{l}\text { 1. Sede união dos moradores } \\
\text { 2. Palco da princesinha } \\
\text { 3. Igreja }\end{array}$ & & Set \\
\hline
\end{tabular}




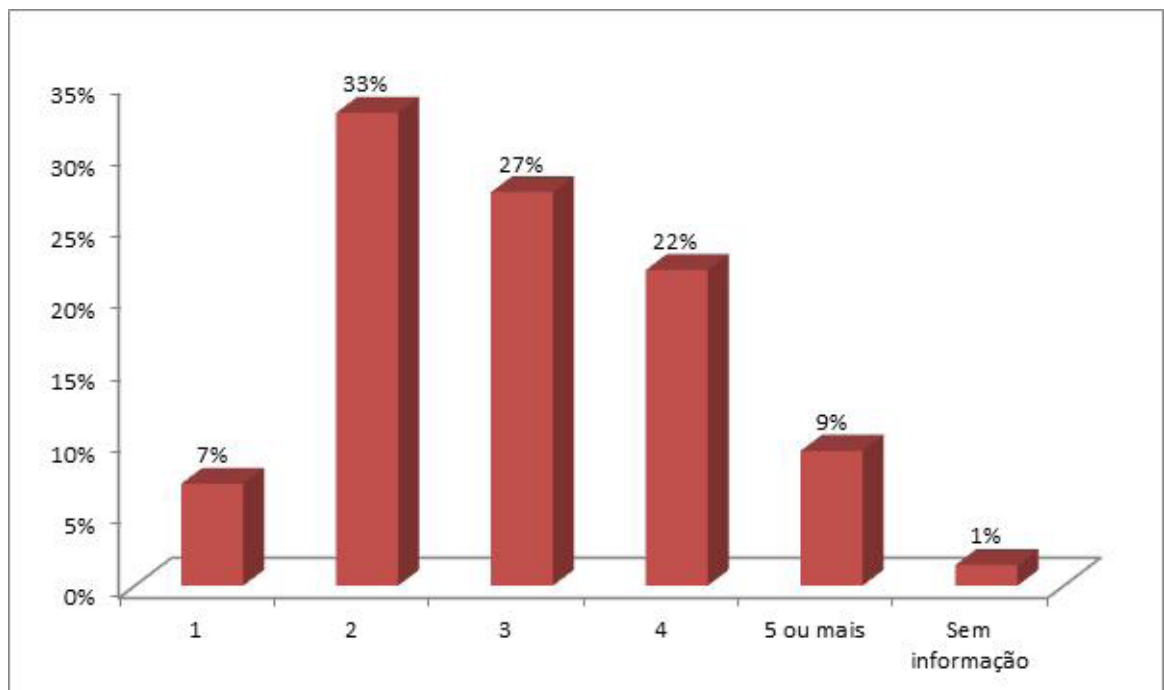

Gráfico 4: Domicílios segundo número de cômodos

Fonte: Pesquisa Censitária Socioeconômica/2012. DPESP/Extrema Construções Ltda.

residências, como pode ser visto no gráfico. 0 número de cômodos indica que as unidades habitacionais do Jardim Jaqueline são, em média, reduzidas, fato que pode estar associado a baixos padrões de habitabilidade oriundos de espaços reduzidos, associados à densidade construtiva.

Apesar de Pedro Abramo considerar o mercado de solo nas favelas "inelástico", já que o aumento da oferta não seria proporcional à demanda, por falta de espaço, o espaço no Jardim Jaqueline parece estar distante do esgotamento, principalmente em relação ao adensamento vertical. Além do crescimento familiar, que gera novos cômodos e novos pavimentos, chama atenção o crescimento para aluguel, que, segundo a pesquisa de Abramo, induz à queda dos padrões de habitabilidade, com a intensificação da precarização de um território já precário.
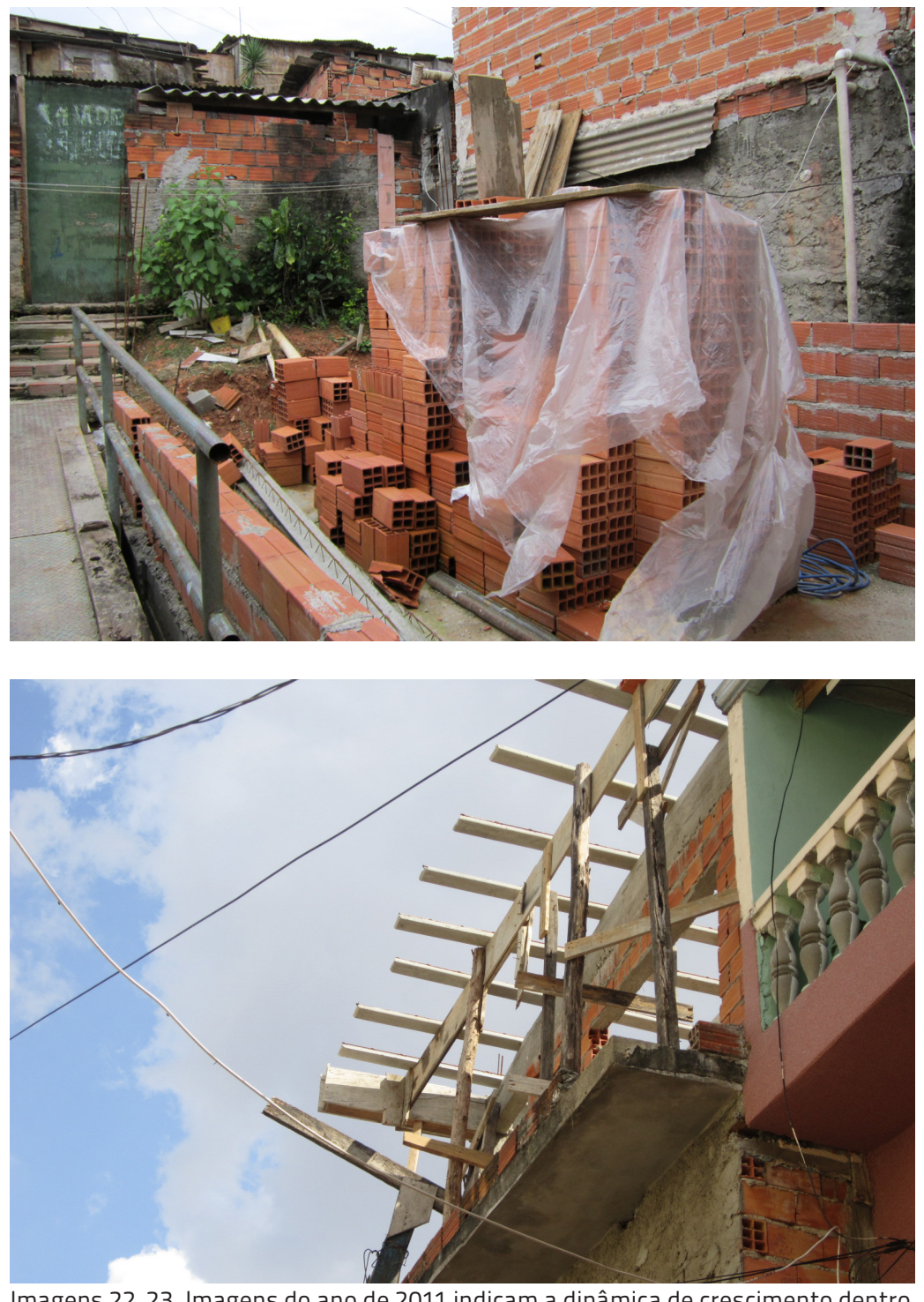

Imagens 22, 23. Imagens do ano de 2011 indicam a dinâmica de crescimento dentro da favela 
A diminuição da densidade por residência, comparada ao grande aumento do número de famílias, de 1.300 em 2000 para 2.867 em 2012, revela que área vem passando por processo de adensamento construtivo, que pode ser comprovado por meio da análise das imagens aéreas e fotos tiradas durante o último ano, que mostram a grande quantidade de novas construções no Jardim Jaqueline, principalmente sobre lajes, trazendo grandes alterações nos gabaritos e morfologia das construções.

Apesar da informalidade que engloba todo o assentamento, 70\% dos moradores cadastrados se intitulam proprietários de suas residências, $25 \%$ vivem de aluguel e outros $4 \%$ residem em local cedido pelo possuidor do imóvel. Dos moradores que se dizem proprietários, $68 \%$ não possuem qualquer documentação que comprove tal propriedade, como um contrato de gaveta, por exemplo. Em relação aos locatários, os valores pagos no aluguel de suas moradias variam de acordo com o gráfico, com média de $\mathrm{R} \$ 307,00$. A maioria, $85 \%$, não possui nenhum tipo de contrato de aluguel.

Em relação aos índices de aluguel, o Jardim Jaqueline, com 25\% de imóveis de aluguel, supera os índices da pesquisa de Pedro Abramo, que indica $17 \%$ de moradias de aluguel. Na mesma proporção, é inferior à porcentagem de moradores que consideram a moradia própria, 70\% no Jardim Jaqueline e $80 \%$ nas regiões metropolitanas pesquisadas pela FINEP. 0 aluguel dentro da favela, motor de especulação imobiliária em torno de um mercado informal, também é fonte ou complemento de renda para parte de seus moradores, que alugam moradias na própria favela, muitas vezes na mesma edificação.

Caminhando pelo Jardim Jaqueline, é possível constatar maior número de placas de "vende-se" nas áreas mais precárias, assim como o adensamento construtivo e o mercado de aluguel. Consideramos a hipótese de que as famílias que alcançam melhores rendimentos acabam se deslocando para pontos

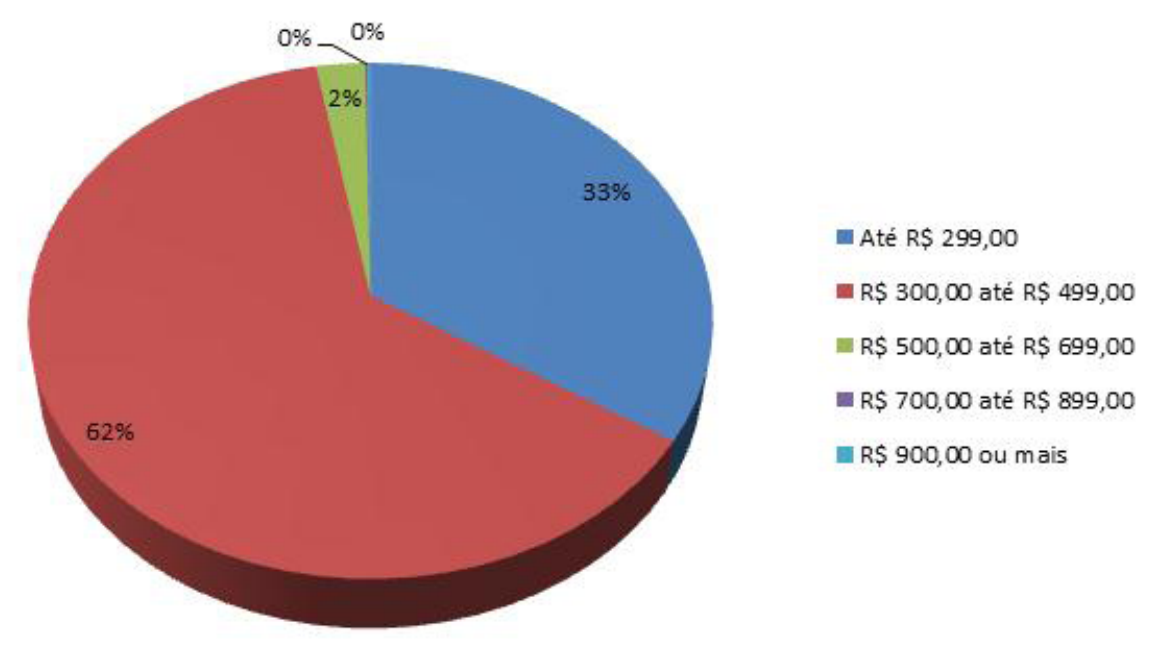

Gráfico 5: Domicílios segundo valor do aluguel

Fonte: Pesquisa Censitária Socioeconômica/2012. DPESP/Extrema Construções Ltda.

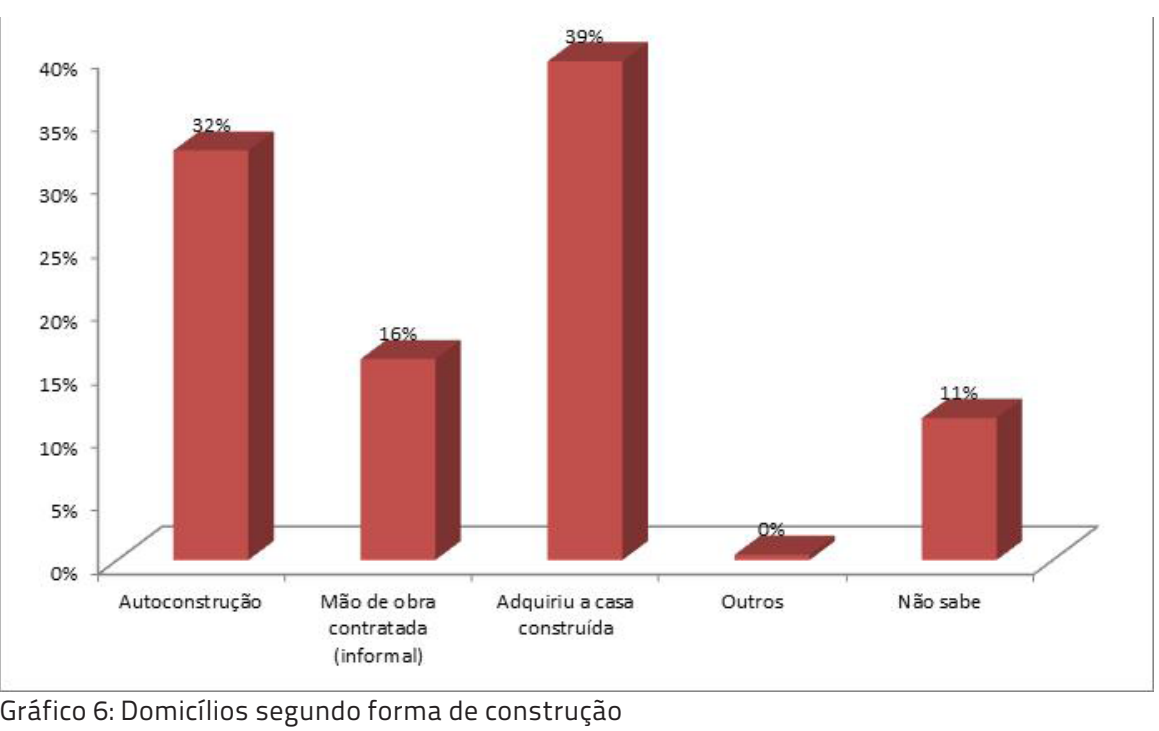

Fonte: Pesquisa Censitária Socioeconômica/2012. DPESP/Extrema Construções Ltda. 
melhores da favela ou para fora da favela, alugando as antigas moradias, ou utilizam-se de seus "espaços de solo" para adensar e gerar renda. A favela conta com lojas de materiais de construção, que facilitam a dinâmica de construção local.

Em relação à forma de construção das moradias, grande parte afirma ter adquirido sua residência construída, dado que corrobora para a constatação da grande taxa de mobilidade ocorrida no local desde sua consolidação. A constante mobilidade interna pode ser verificada pelo grande número de domicílios a venda, mesmo antes da efetivação do processo de regularização fundiária. Como se trata de assentamento antigo e consolidado, a maioria das construções é em alvenaria, 98\%, sendo que a maioria das edificações em madeira está localizada próximo do ou sobre o curso d'água.

Em relação ao tempo de moradia, pensando nos critérios para obtenção da usucapião urbana, $65 \%$ das famílias está há mais de cinco anos no local e 35\% há menos de cinco anos, sendo que grande parte dos novos moradores vive de aluguel. 0 tempo médio de permanência dos moradores no Jardim Jaqueline é de nove anos e seis meses.

Os padrões de mobilidade também se aproximam da pesquisa da FINEP, que aponta que metade das pessoas que moram em favelas moram há menos de dez anos, demonstrando que existe uma forte mobilidade residencial intrafavela, já que $60 \%$ se mudam para a própria favela.

Apesar da ausência desse dado de mobilidade para o Jardim Jaqueline, pode-se relacionar os altos índices de aluguel, com locadores morando no Jardim Jaqueline, à mobilidade desses locadores na mesma área, com a construção de novas residências e locação da antiga.

Apenas 3\% dos domicílios cadastrados são ocupados por herdeiros de antigos possuidores. A grande maioria (97\%) dos moradores afirma não possuir
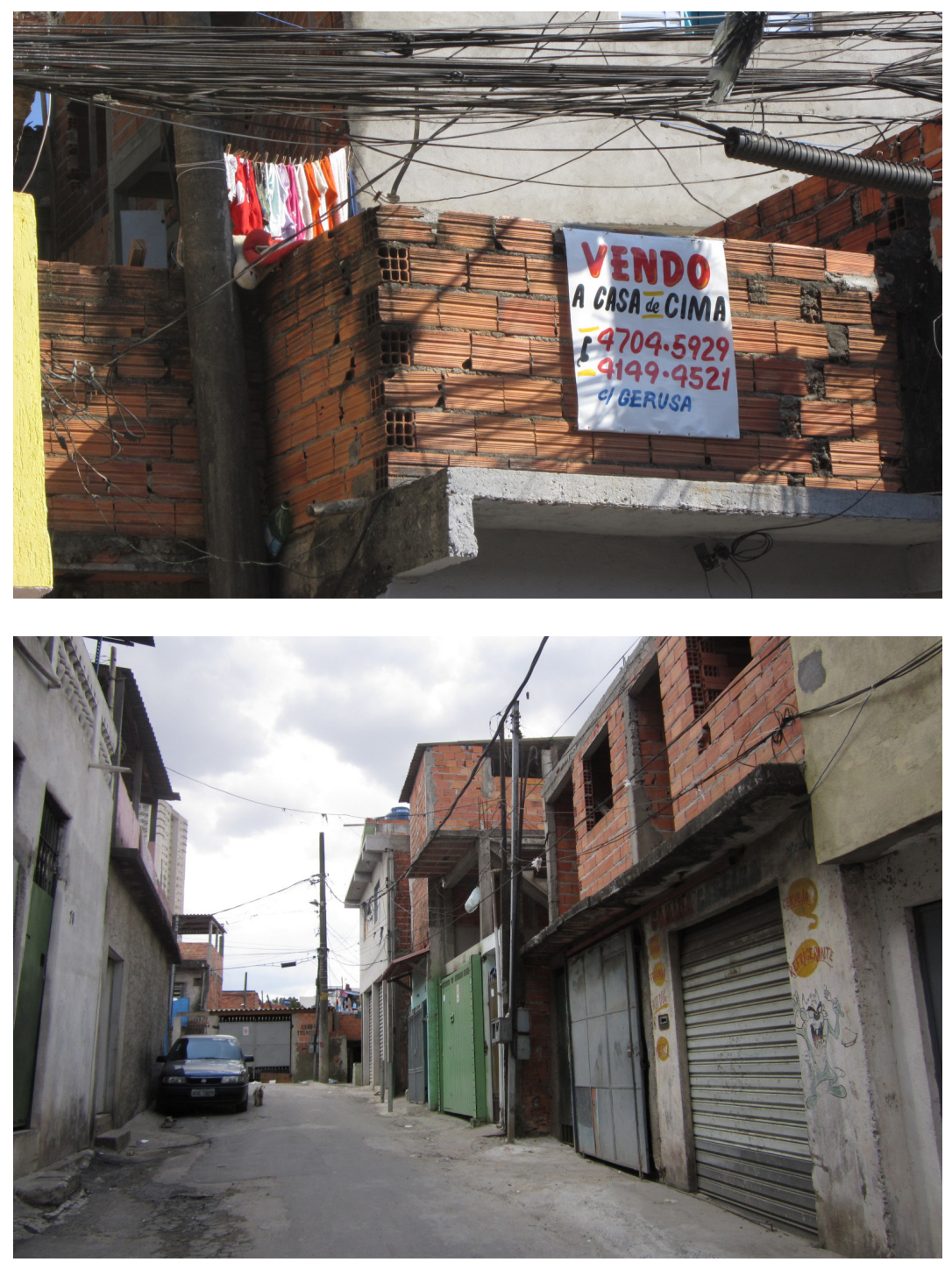

Imagens 24, 25. Comercialização de domicílios e novas construções para moradia própria ou aluguel indicam alta taxa de mobilidade interna 
outra propriedade, indicando que o Jardim Jaqueline é a única possibilidade de moradia para a maioria de seus ocupantes.

\begin{tabular}{cccc}
\hline Categoria & $\begin{array}{c}\text { Município de } \\
\text { São Paulo }\end{array}$ & Jardim Jaqueline & $\begin{array}{c}\text { Setor 4 } \\
\text { CIT }\end{array}$ \\
\hline Energia elétrica: & $86 \%$ & $53 \%$ & $28 \%$ \\
ligação exclusiva & $\mathbf{9 9 \%}$ & $\mathbf{8 0 \%}$ & \\
Abastecimento de água & $90 \%$ & $74 \%$ & $50 \%$ \\
Ligação à rede de esgoto & $\mathbf{9 9 \%}$ & $\mathbf{9 3 \%}$ & \\
Coleta de lixo & & &
\end{tabular}

Além da deficiência em relação à infraestrutura instalada, que revela a precariedade em relação às condiç̧̃es de moradia, principalmente em relação aos moradores do setor 4 (CIT), o padrão de uso dos serviços públicos disponíveis mostra a falta de inclusão de grande parte dos moradores do Jardim Jaqueline em relação a equipamentos culturais e de inclusão social, como o Centro de Cultura e o Centro de Referência de Assistência Social (CRAS), além dos serviços básicos de educação como escolas e creches. 0 baixo índice de utilização das creches públicas pode estar associado à falta de vagas ou distância, já que foram identificadas creches informais no Jardim Jaqueline.

Ao contrário dos equipamentos de educação e cultura, o sistema de saúde e transporte público é amplamente utilizado pela população local. 0 padrão de utilização dos serviços públicos demonstra que a educação e a cultura não são consideradas como prioridades para grande parte dos moradores do Jardim Jaqueline, por falta de interesse ou principalmente por não se tratar de um valor que faça parte de seu cotidiano. 0 fato de a cultura ser um valor distante pode ser associado ao papel central que o consumo exerce sobre todos os extratos sociais, que no local é representado pelo Shopping vizinho à favela, que não consta na pesquisa, mas é frequentado por grande parcela dos moradores. 0 distanciamento em relação às atividades culturais está diretamente relacionado

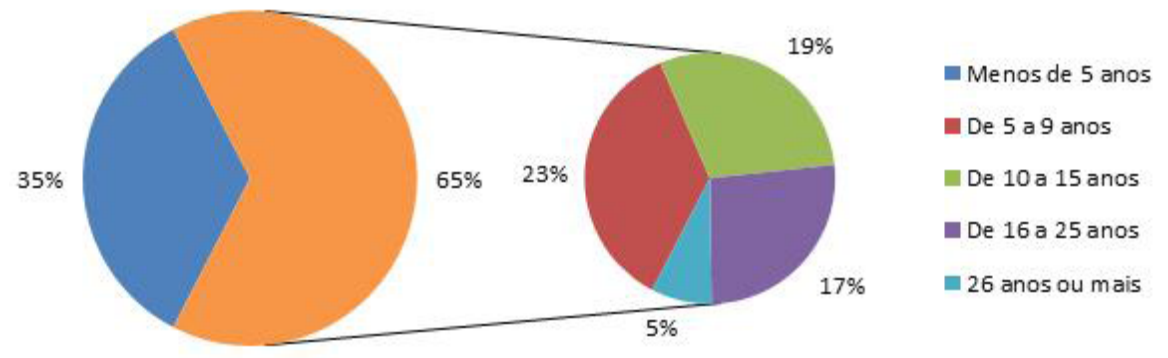

Gráfico 7: Detalhamento dos domicílios segundo tempo de residência Fonte: Pesquisa Censitária Socioeconômica/2012. DPESP/Extrema Construções Ltda. 
aos fracos vínculos estabelecidos com a escola. Outro dado importante, sobre inclusão digital e padrão de consumo associado a um tipo de apropriação cultural do espaço, diz respeito ao uso da internet. Dos $47 \%$ dos moradores que dizem ter acesso à internet, o acesso por lan houses (23\%) supera significativamente o uso do telecentro (1\%), localizado no vizinho Centro de Segurança Alimentar (CRSANS-BT). Os outros moradores $(65 \%)$ usam a rede em casa.

No outro extremo encontram-se os serviços socialmente considerados como imprescindíveis, como a saúde e o transporte público, cuja utilização generalizada revela o padrão de deslocamento dos moradores.

O baixo índice de utilização do Centro de Referência de Assistência Social (CRAS) e do Centro de Referência em Segurança Alimentar e Nutricional Sustentável (CRSANS-BT), é decorrente do desconhecimento dos moradores em relação aos equipamentos, mas principalmente devido ao papel que a Associação de Moradores exerce no cotidiano local, substituindo o papel da Assistência Social do Estado. A Associação distribui leite e eventualmente comida, organiza eventos para as crianças e sedia cursos de capacitação em parceria com prefeitura, instituições beneficentes e empresas privadas.

Fato curioso ocorreu em um dos eventos, realizado para o projeto de regularização fundiária, que deveria contar com a presença maciça dos moradores para a divulgação de uma cartilha de capacitação em relação ao processo em curso. Como a sede da associação de moradores não contava com grande espaço físico, as reuniões foram marcadas no CRSANS-BT, com melhor infraestrutura, que fica a poucos metros do local habitual de reuniões, em área com localização acessivel. Apesar de todas as facilidades, as reuniões não tiveram os mesmos índices de comparecimento verificados nas anteriores. 0 baixo comparecimento dos moradores não pode ser considerado fato isolado, já que, de acordo com o diagnóstico socioeconêmico, a Associação de Moradores é reconhecida por 76\% dos entrevistados, enquanto o CRSANS-BT é conhecido somente por $20 \%$ dos moradores do Jardim Jaqueline. Considerando a conjuntura política local, pode-se presumir que a união ou eventual parceria entre a associação de moradores local e estruturas de assistência social das imediações seria inviável por diferenças político-partidárias.

O transporte público tem papel central no cotidiano dos moradores, como indica a pesquisa. Além do indicador, a importância do transporte coletivo pode ser mensurada nas discussões travadas nos encontros de representantes dos moradores, promovidos no âmbito do projeto de regularização fundiária. Uma das questões mais debatidas nas reuniões foi a alteração de itinerários de ônibus que passam nas proximidades, que afetam grande parte dos moradores que precisam se deslocar até o centro ou outros pontos de interesse, como o Hospital das Clínicas. O novo sistema propõe como pontos finais a nova estação de metrô, que levaria à utilização de duas passagens, dificultando os deslocamentos até as áreas 
centrais. Hoje, a facilidade em relação aos deslocamentos é apontada como uma das vantagens locacionais do Jardim Jaqueline.

Em relação aos indicadores apontados entre 1991 e 2000, de acordo com metodologia do CEM, não podemos fazer a comparação em relação aos indicadores para o Jardim Jaqueline de 2012, mas podem-se estabelecer relações com os índices do HABISP (base de dados do município) de $2001^{6}$. As informações dessa base de dados indicam que a favela possui baixos índices de infraestrutura urbana em todos os quesitos analisados; porém, os dados levantados pela Defensoria Pública em 2012 mostram que os indicadores do HABISP não refletem a realidade local, que estaria mais próxima dos resultados encontrados pela pesquisa de Marques e Saraiva (2004), que traz estimativas para o município de São Paulo.

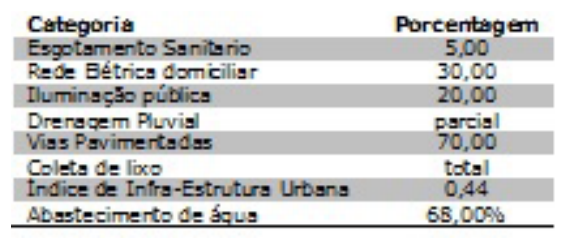

Tabela 2: Estimativa de infraestrutura urbana no Jardim Jaqueline Fonte: HABISP

\begin{tabular}{|c|c|c|c|c|}
\hline \multirow{2}{*}{ Indicsd ores } & \multicolumn{2}{|c|}{ Números relativos } & \multicolumn{2}{|c|}{ Números relativos } \\
\hline & Favelas 1991 & MSP 1991 & Favelas 2000 & MSP 2000 \\
\hline $\begin{array}{l}\text { Domiólios com } \\
\text { aggua }\end{array}$ & 89,7 & 98,3 & 96,0 & 97,6 \\
\hline $\begin{array}{l}\text { Domicílios com } \\
\text { coleta de lixo }\end{array}$ & 63,3 & 95,2 & 82,0 & 96,5 \\
\hline $\begin{array}{l}\text { Domicílios com } \\
\text { esgotamentomto }\end{array}$ & 25,1 & 81,2 & 49,2 & 87,2 \\
\hline
\end{tabular}

Tabela 3: Estimativas de infraestrutura em favelas de São Paulo, segundo o CEM Fonte: Marques e Saraiva (2011)

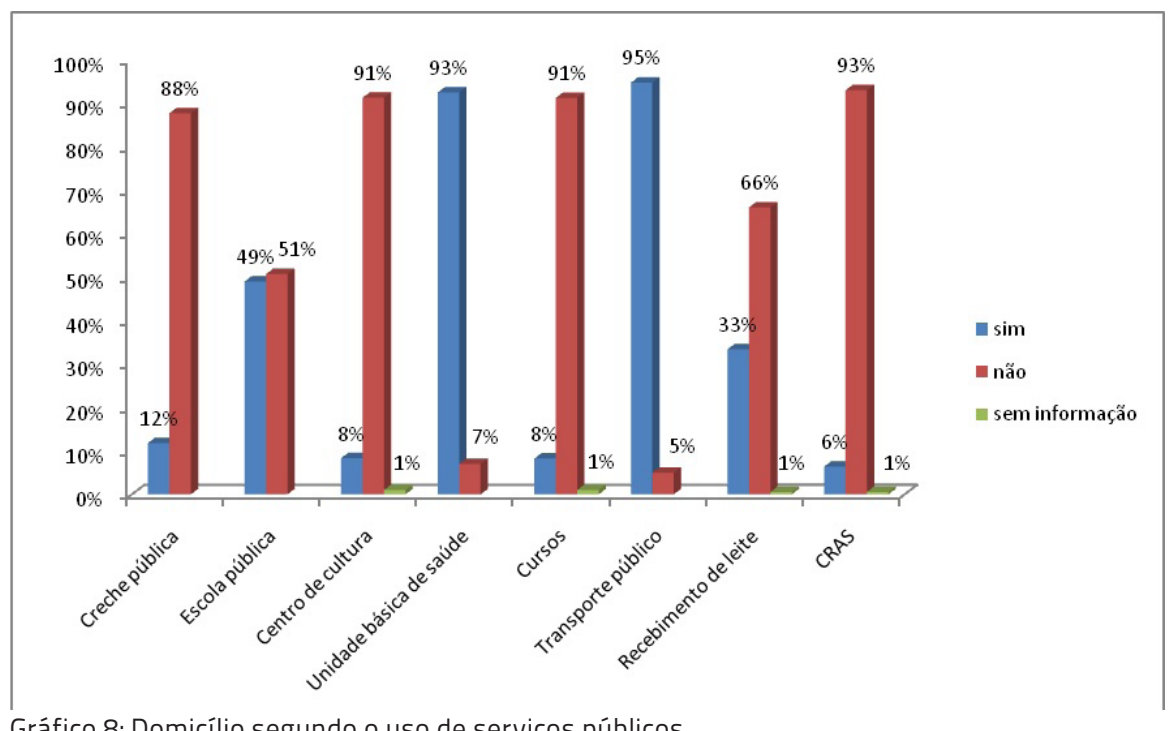

Fonte: Pesquisa Censitária Socioeconômica/2012. DPESP/Extrema Construções Ltda.

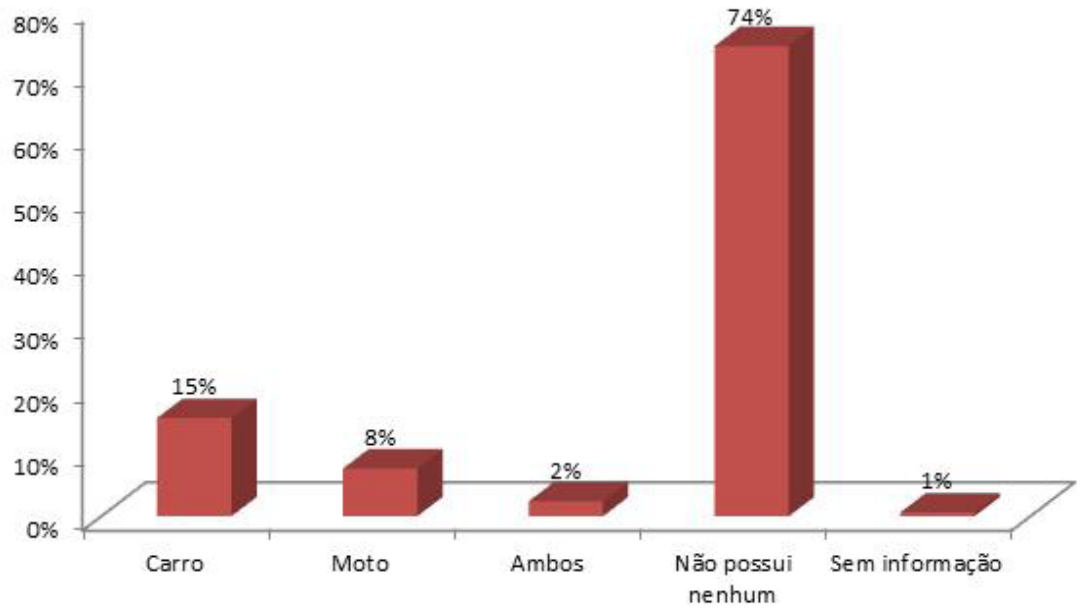

Gráfico 9: Domicilios segundo a posse de carro ou moto

Fonte: Pesquisa Censitária Socioeconômica/2012. DPESP/Extrema Construções Ltda. 


\section{EVOLUÇÃO URBANA: O JARDIM JAQUELINE E O CRESCIMENTO DAS FAVELAS EM SÃO PAULO}

Considerando o trabalho de Eduardo Marques e Camila Saraiva sobre a evolução das favelas no município de São Paulo, notamos que até a década de 1980 a dimensão da questão era muito pouco relevante, como visto no levantamento da prefeitura de São Paulo realizado em 1973, que indicou cerca de 70 mil habitantes ou 1\% da população do município. A questão das favelas ganhou visibilidade quando uma pesquisa também realizada pela prefeitura, em 1987, indicou que a população favelada havia alcançado 812.000 habitantes, ou 9 \% da população do Município. 0 Censo de 1991 confirmou esse crescimento, indicando cerca de 650.000 habitantes em setores subnormais, contra 375 mil habitantes em 1980. Em 1993, pesquisa da Fipe-USP trouxe grande alarde, com uma estimativa de 1,9 milhões de favelados.

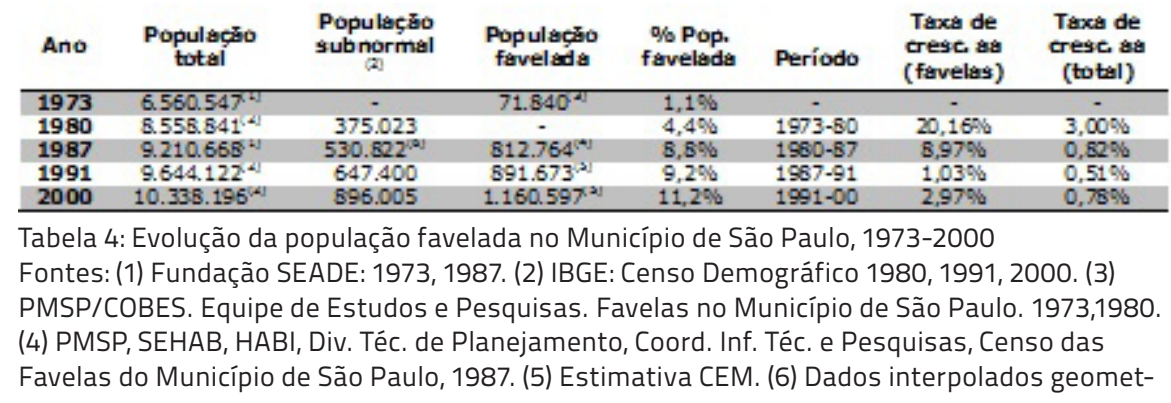

Apesar das diferenças nas estimativas dos diversos órgãos de pesquisa, decorrentes de métodos diversos de análise, o que interessa no âmbito desta dissertação, é o grande aumento da população favelada entre 1973 e 1980, que cresceu a uma taxa de $20,16 \%$ ao ano, contra $3 \%$ de crescimento populacional no município.

A pesquisa de Marques e Saraiva (2004) constata que, apesar de novas estimativas do CEM demonstrarem que o número de favelados não cresceu como divulgado pela Fipe, após o grande crescimento verificado até 1980, o Município continuou experimentando um considerável processo de favelização, com a população favelada crescendo mais de três vezes a taxa do conjunto da cidade. Tal crescimento da habitação informal é explicado em diversos trabalhos acadêmicos que tratam do processo de urbanização de São Paulo e da redução do custo da mão de obra decorrente da invasão de terras e autoconstrução?.

Esses dados vão ao encontro das análises de evolução urbana do Jardim Jaqueline, efetuadas por meio de imagens aéreas de 1958, 1973, 1987, 2002 e 2011 e confirmadas com entrevistas pontuais realizadas com os moradores, no âmbito
6 Disponivel em: <http://www.habisp.inf. br>. Acesso em: 29 Jul. 2013.

7 Cito os importantes trabalhos de Francisco de Oliveira, O Estado e o Urbano no Brasil, de 1982, e Ermínia Maricato, Metrópole na Periferia do Capitalismo: ilegalidade, desigualdade e violência, de 1996. 
do projeto de regularização fundiária. Entre as imagens de 1973 e 1987, nota-se intenso processo de ocupação da área, que se estabilizou em 2002, incluindo-se as APPs, como pode ser visto no item sobre sua evolução urbana.

\subsection{HISTÓRICO DE OCUPAÇÃO DO JARDIM JAQUELINE}

O imóvel original que deu origem ao assentamento aparece nas matrículas oficiais com as seguintes características:

[...] com cerca de 10 alqueires, situado na altura do Km. 14,5 da Estrada de Cotia, no lugar denominado Cercado do Alto ou Água Podre, situado do lado esquerdo da referida estrada de quem de São Paulo se dirige à Cotia, tendo como proprietários 06 (seis) pessoas, com distintas frações ideais [...] constituída de terras incultas, sem benfeitorias de valia.

A matrícula que deu origem à maior fração de terras do Jardim Jaqueline pode ser resumida de acordo com a seguinte tabela:

\begin{tabular}{|c|c|c|c|}
\hline Matrícula 49.604 & \multicolumn{3}{|c|}{ Área total: $205.900,00 \mathrm{~m}^{2}$} \\
\hline Proprietários & Fragcōes & Alienaçōes & \multirow{6}{*}{ 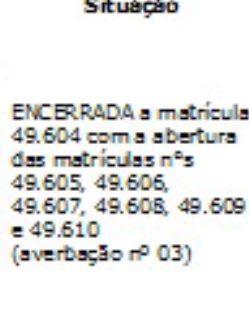 } \\
\hline $\begin{array}{l}\text { VICENTE MONTE RO = s/mer. LUCIND,A CANTE RO } \\
\text { MONTEIRO }\end{array}$ & $1 / 12$ & $\begin{array}{l}\text { Quinhso } 1 \\
\text { Matr. } n^{\circ} 49.605 \\
\end{array}$ & \\
\hline FORTUNATA MONTEIRO & $1 / 12$ & $\begin{array}{l}\text { Quinh3o } 2 \\
\text { Matr. } n^{\circ} 49.606\end{array}$ & \\
\hline JOAO SINHO CALIENTE IVO & $1 / 12$ & $\begin{array}{l}\text { Quinhso } 3 \\
\text { Matr. } \pi^{\circ} 49.607\end{array}$ & \\
\hline DEOBRA S/A EMPREENDIMENTOS IMOBTLLÁRTOS & $1 / 12$ & $\begin{array}{l}\text { Quinhso } 5 \\
\text { Matr. } .^{\circ} 49.608\end{array}$ & \\
\hline $\begin{array}{l}\text { ROBERTO KALED MALUF }=\mathrm{s} / \mathrm{m} \text { r. SILVANA } \\
\text { CARRARO MALUF } \\
\text { EDMUNDO MALUF } \mathrm{e} / \mathrm{s} \text { mer. VERA RACY MALUF }\end{array}$ & $8 / 12$ & $\begin{array}{l}\text { Matr. } \text { no }^{\circ} 49.609 \\
\text { verdido a } \\
\text { DEOBRA } S / A \\
\left.\text { (regietro } \text { nO }^{\circ} 02\right)\end{array}$ & \\
\hline
\end{tabular}

Fonte: Diagnóstico Jurídico Jardim Jaqueline/2012. DPESP/Extrema Construções Ltda.

Mais do que o natural interesse pelos nomes envolvidos no jogo de propriedades e trâmites registrários, importantes em larga escala para identificação dos grandes proprietários de terras urbanas de São Paulo, essa pequena amostra indica como os trâmites cartorários seguem apartados dos reais destinos desses locais. Quando a matrícula principal foi encerrada, em 1982, com a venda do maior quinhão, a área estava em processo de ocupação e, na mesma década, Eliseu Chagas Branco e sua mulher, Rosilene Mendes Branco, venderam lotes do que seria o loteamento Vila Albano, localizado na mesma matrícula do Jardim Jaqueline. Como o loteamento contou com desenho de lotes e traçado viário, foi regularizado perante

8 Matrícula $n^{\circ} 49.604$ registrada junto ao $18^{\circ} \mathrm{CRI}$ da Capital. 


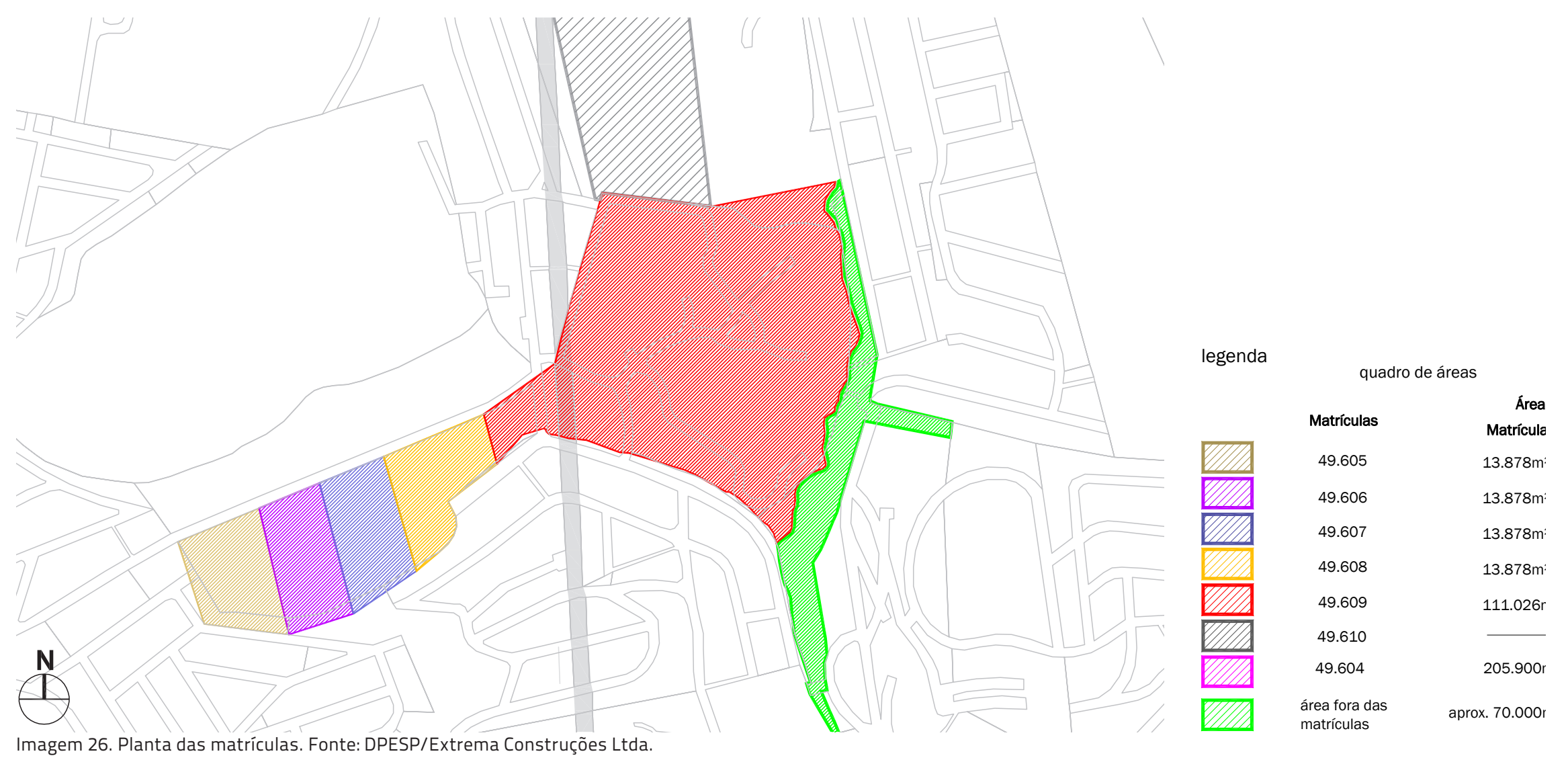


o município, sem averbação em matrícula ou regularização fundiária dos lotes ${ }^{9}$. Dado muito importante para o entendimento dos meandros da lei diz respeito à atual situação legal da referida matrícula (49.609), penhorada em favor da municipalidade de São Paulo desde $2002^{10}$.

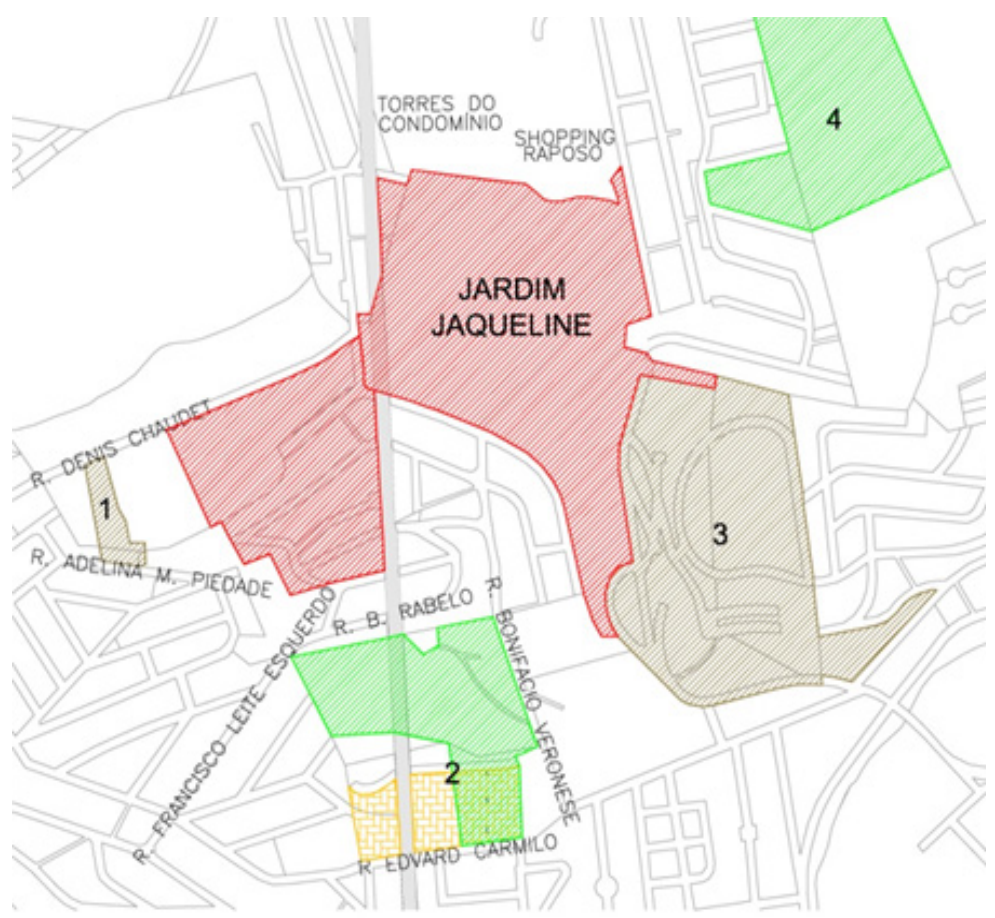

ZEIS1 - Zona Especial de Interesse Social - 1

ZEIS2 - Zona Especial de Interesse Social - 2

$\stackrel{N}{(1)}$

ZEPAM - Zona Especial de Proteçåo Ambiental

SEM ESCALA

ZM-p (apenas áreas ainda não ocupadas) - Zona Mista de Proteção Ambiental

\section{Faixa da Rede de Transmissão de Energie Elétrica}

Fonte: Secretaria de Planejamento - Prefeitura de São Paulo, disponível em: http://www.habisp.inf.br/; Plano Diretor Estratégico, Lei n¹3.430/2002; e Plano Regional Específico do Butantã, Lei n¹3.855/2004.

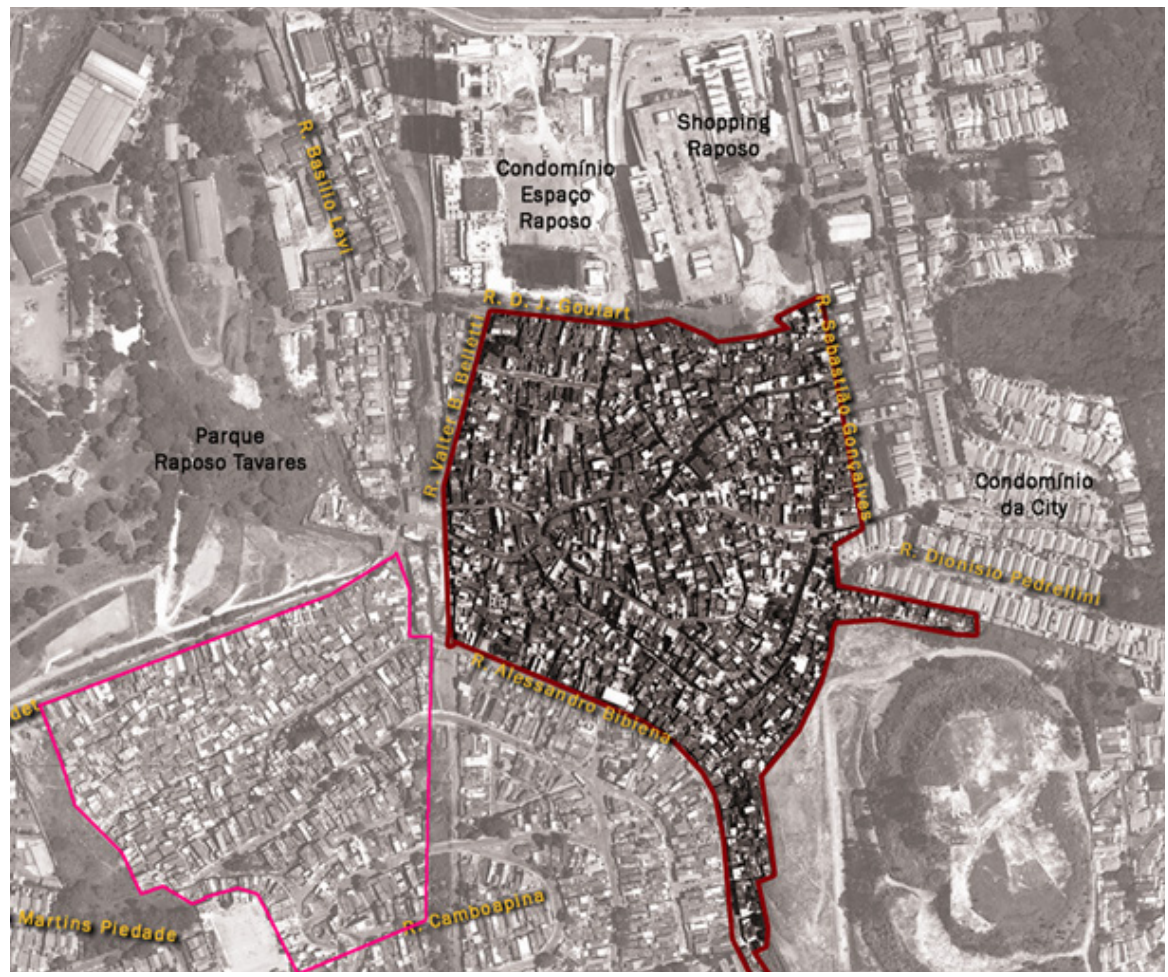

Imagens 27, 28. Fonte: Google Earth (acessado em março de 2012).

9 Planta AU 6472 disponivel no departamento de regularizações da prefeitura - RESOLO. A ausência de averbação foi justificada pela falta de título de domínio por parte do loteador.

10 A matrícula $n^{\circ} 49.609$ indica a existência de um registro de penhora com data de primeiro de abril 2002, em favor da prefeitura do município de São Paulo para quitação da divida ativa de número 538275-0/86, mas o imóvel ainda não foi adjudicado pela municipalidade. 


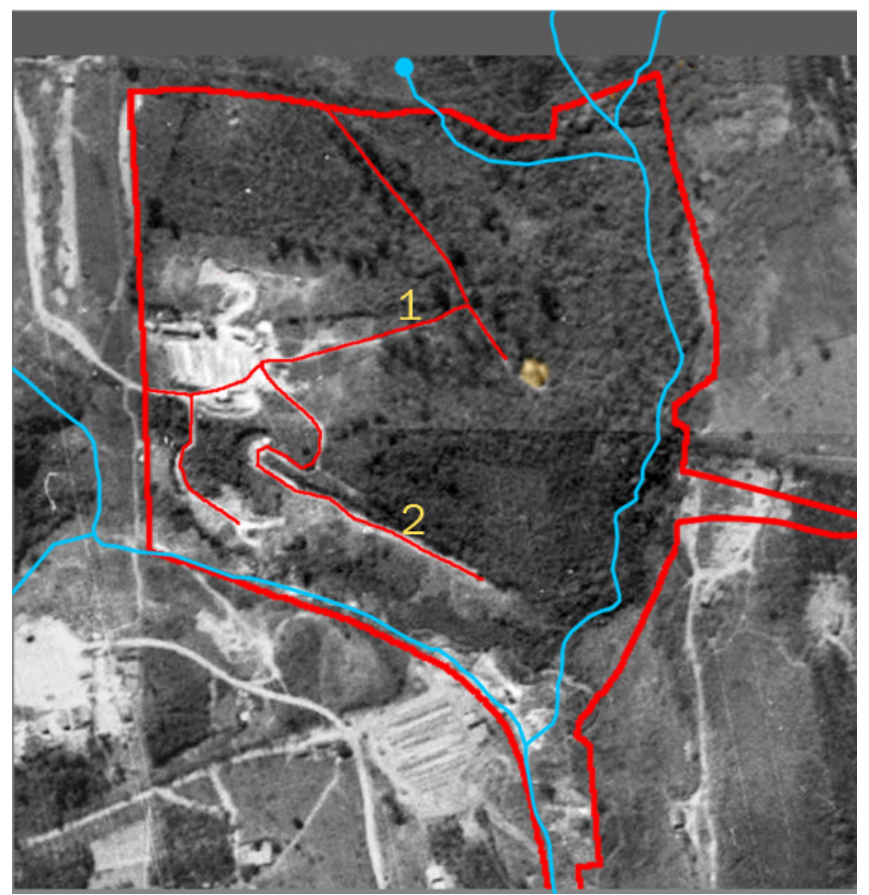

Imagem 29. 1958

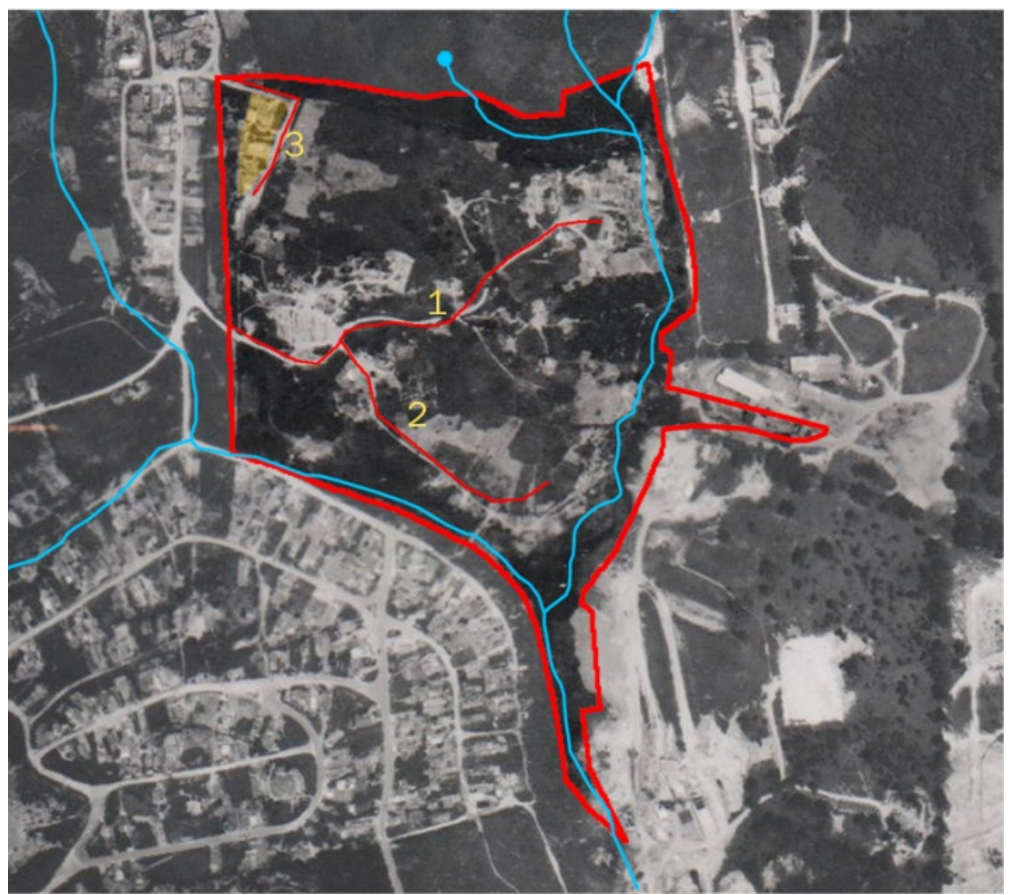

Imagem 30. 1973

Na matricula $n^{\circ}$ 49.605, foi implantado o Condomínio Bosque do Butantã, e na matrícula n 49.608, o Condomínio Residencial Espaço Raposo, em terreno grafado como ZEIS 2 pela municipalidade em 2002. A faixa de transmissão da concessionária de energia elétrica, que coincide com a faixa de dutos da Petrobrás, divide as favelas Jardim Jaqueline e Vale da Esperança/Morro da Fumaça, mas não possui qualquer registro de instituição de servidão ou transferência de domínio.

A análise de imagens aéreas mostra que, em 1958, a área onde se encontra a favela e seu entorno ainda estavam vazios, ocasião em que o processo de expansão urbana do município ainda não havia atingido as imediações. A mesma imagem indica a atividade das olarias existentes na área e de criação de porcos, relatadas pelos moradores mais antigos, de acordo com entrevistas realizadas para o processo de regularização fundiária ${ }^{11}$. Deduz-se pela imagem que os primeiros moradores foram os funcionários das olarias que operavam na área, cuja atividade deu nome à principal via de acesso ao assentamento.

11 Foram realizadas entrevistas com moradores do Jardim Jaqueline, por parte da empresa contratada pela Defensoria Pública, que trazem informações a respeito do processo de ocupação do território. No capítulo seguinte, traremos novos dados sobre o histórico de ocupação da favela por meio da pesquisa qualitativa desenvolvida para a pesquisa. 
De acordo com o relato de moradores e a base de dados oficial do município, as primeiras construções datam da década de 1960. A imagem de 1973 já mostra o prolongamento das vias de acesso associado às grandes áreas desmatadas pela atividade das olarias. Também se pode notar a abertura de arruamentos de loteamentos vizinhos. Em 1987, nota-se que grande parte da área estava ocupada e que os cursos d'água ainda estavam em seu leito natural, com poucas ocupações nas APPs. As entrevistas indicam que a primeira fase de ocupações é caracterizada por uma população originária de outros estados, principalmente da Bahia. No mesmo ano, já havia loteamentos regulares localizados no entorno imediato, como é o caso do Jardim Olympia e do Jardim Divina Providência, cujas reservas de áreas verdes do loteamento foram ocupadas pelo Jardim Jaqueline.
Legenda

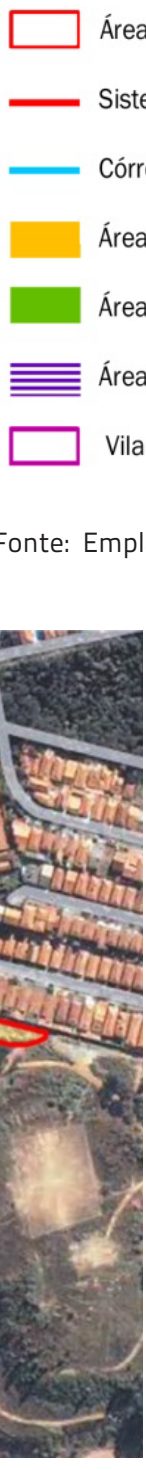

Área da ZEIS 1 - $141.742 \mathrm{~m}^{2}$

1. avenida das Olarias

2. rua da Cerámica

3. rua Walter Brito Belleti

4. rua Joaquim Alves

5. rua Pedro Bezerra

6. rua $F$

7. rua Gomes

8. rua Julio Batista

9. rua Brasil

10. rua Vitão

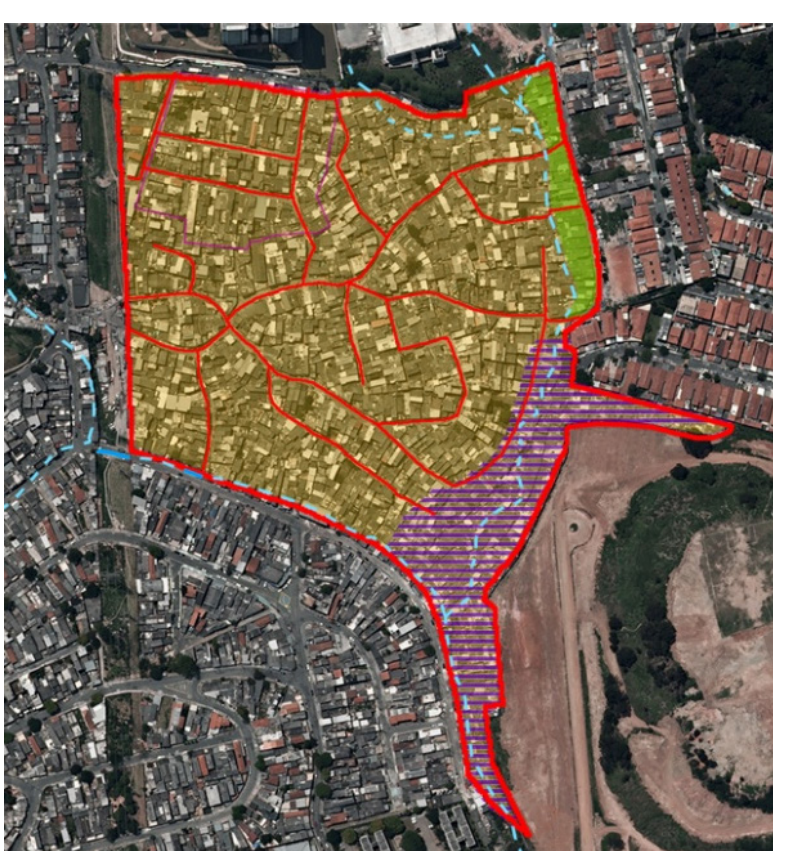

Imagem 33. 2011

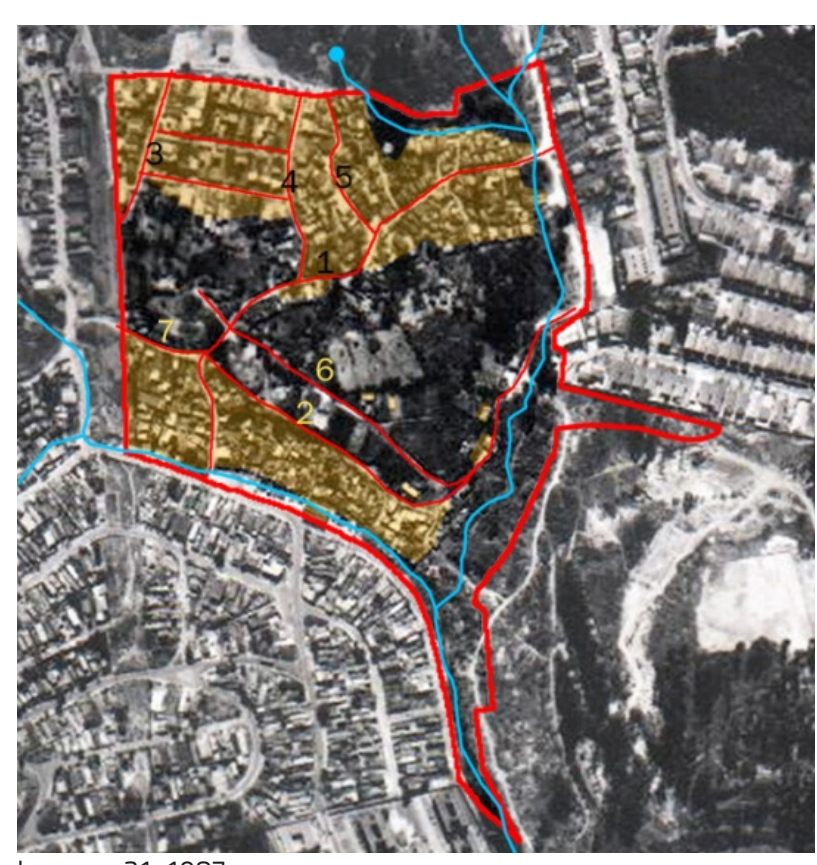

Imagem 31. 1987

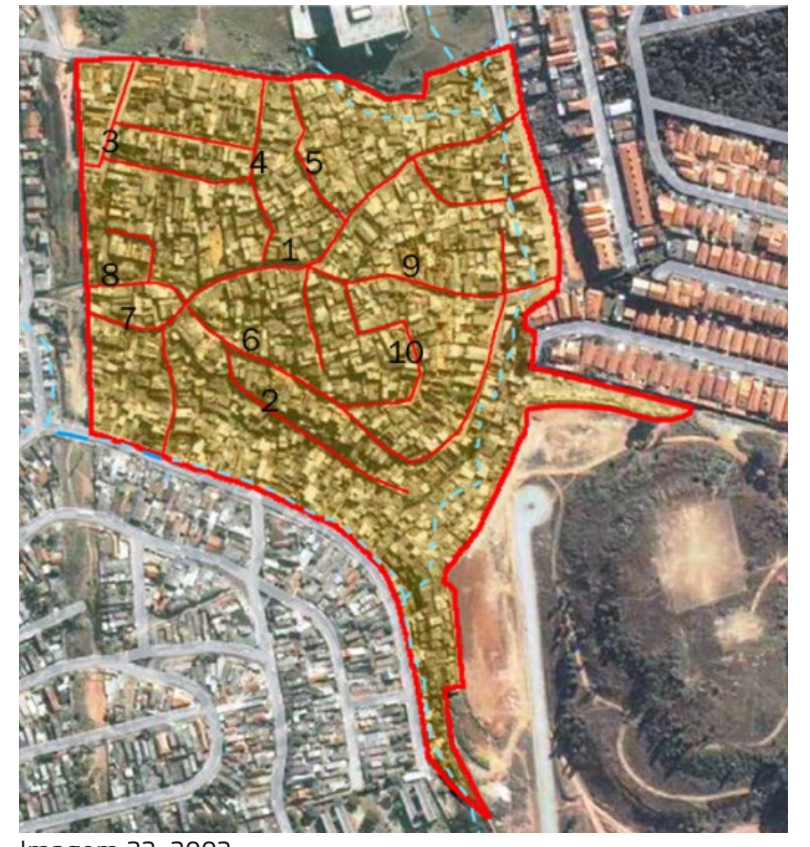

Imagem 32. 2002 
O processo de ocupação, entre 1973 e 1987, segue o fenômeno de crescimento das favelas no município de São Paulo (MARQUES; SARAIVA, 2011) derivado do particular processo de industrialização da região metropolitana. Até 1987, verificamos dois focos de ocupação, um próximo à rodovia Raposo Tavares e outro ao sul, nas proximidades do loteamento Jardim Jaqueline. O adensamento da área ocorreu na década de 1990 e, em 2002, podemos ver a favela praticamente em sua atual conformação, com exceção de algumas áreas da chamada CIT, nome do proprietário da gleba (CIT Engenharia e Comércio), cujo processo de ocupação se intensifica entre 2002 e 2011.

A partir do processo de ocupação horizontal analisado por meio das imagens aéreas, intensifica-se o processo de crescimento vertical da favela, com a construção de novas lajes, em um processo contínuo, dando indícios de que a favela ainda possui grande potencial de crescimento.

Apesar do tempo de ocupação, a luz elétrica chegou apenas no final da década de 1980, e o processo de urbanização, ou simplesmente de "melhorias" na área, começou em 2002, quando foram implantadas redes coletoras de esgoto, ligações domiciliares de água e esgoto, construção de galerias pluviais e de guias e sarjetas. Hoje, a maioria das construções é de alvenaria, organizada de forma adensada e em processo de verticalização. Nas áreas de ocupação mais recente, as construções são extremamente precárias, algumas em madeira.

O que restou do processo oficial de instalação de infraestrutura foi realizado pelos próprios moradores, que, com o adensamento da área, promoveram pavimentações de vielas, ligações clandestinas de água, esgoto e energia elétrica. As redes de energia elétrica e de água das principais ruas são oficiais, com exceção das áreas de ocupação recente, mais precárias. 0 processo de manutenção da pavimentação das vielas e instalação de pequenos equipamentos, como lixeiras e lombadas, é constante no Jardim Jaqueline, principalmente em anos de eleições municipais.

Como podemos ver pela análise evolutiva da área, o assentamento extrapolou os limites da matrícula original, envolvendo novos proprietários e novas histórias no processo de investigação para regularização fundiária. A nova composição de propriedades pode ser resumida pela tabela vista na página seguinte ${ }^{12}$.

Podemos ver que o processo de ocupação mais recente do Jardim Jaqueline problematizou a situação fundiária da ocupação, introduzindo áreas públicas e novas áreas particulares, de diversos proprietários. Juridicamente, esse tipo de situação causa grandes dificuldades para a propositura de ações de usucapião, para áreas particulares, e de Concessão de Uso Especial para Fins de Moradia, para as áreas públicas, com envolvimento de diversos atores que deverão ser citados nas ações.
12 Os números das matrículas relacionadas às frações citadas e todas as fontes de pesquisa fazem parte dos relatórios de execução de atividades apresentados pela empresa Extrema Construções Ltda. para o processo de regularização fundiária promovido pela Defensoria Pública do Estado. Os dados da pesquisa estão disponíveis para consulta no Núcleo de Habitação e Urbanismo da Defensoria Pública. 
Do ponto de vista urbanístico, a evolução urbana dessa área aponta outros problemas. Como podemos ver em diversas ocupações de baixa renda na cidade, a ocupação de áreas públicas é realizada nas reservas de áreas verdes de loteamentos regulares, que, sem projetos ou destinações pré-estabelecidas, tornam-se espaços preferenciais de ocupações informais. 0 grande agravante nesse processo é que a cidade perde seus espaços livres e o potencial de criação de espaços coletivos de qualidade, como pode ser visto no entorno próximo ao Jardim Jaqueline, sem espaços de convivência e recreação. Chama atenção, nesse caso, o fato de que não foi somente a favela que avançou sobre os espaços livres públicos e as APPs, mas também o Shopping Raposo, instalado na área na década de 1990, como pode ser visto na imagem aérea e no chamado "Mapa de Confrontantes". Os moradores antigos lembram das nascentes que existiam no lugar, ou bicas d'água, como são chamadas, utilizadas para banho e recreação antes de serem tamponadas pelo Shopping. Dessa forma, podemos dizer que a favela ocupou os espaços livres de recreio dos loteamentos Jardim Independência, Jardim Divina Providência e Jardim Jaqueline, e a favela e o Shopping ocuparam a área de lazer do loteamento Jardim Olympia.

\begin{tabular}{|c|c|c|c|}
\hline Origem & $\begin{array}{l}\text { Designaģăo segundo } \\
\text { Registro de Imóveis }\end{array}$ & Título & Proprietário \\
\hline \multirow{3}{*}{$\begin{array}{l}\text { Áres } \\
\text { particular }\end{array}$} & Quinháo no 5 & $\begin{array}{l}\text { Matrícula } 49.609 \text {, do } 15^{\circ} \\
\text { Cartório de Registro de Imbveis }\end{array}$ & $\begin{array}{l}\text { DEOBRA S/A } \\
\text { BMRREENDIMENTOS E } \\
\text { PARTICI PACOES }\end{array}$ \\
\hline & $\begin{array}{l}\text { Ares A } \\
\text { Ares B } \\
\text { Ares C }\end{array}$ & 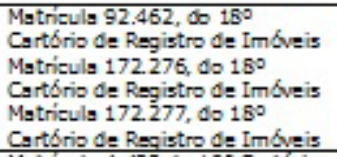 & $\begin{array}{l}\text { ARCOBRAS COMERCIAL E } \\
\text { INCORPORADORA LTDA. }\end{array}$ \\
\hline & $\begin{array}{l}\text { Ares D } \\
\text { Ares F }\end{array}$ & 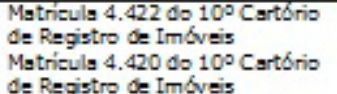 & $\begin{array}{l}\text { CTI ENGENHARIA E } \\
\text { COMÉRCIO } S / A^{2}\end{array}$ \\
\hline & $\begin{array}{l}\text { Espago livre } 1 \text { do ja. Diving } \\
\text { Provididncis } \\
\text { Ares de larer no } 1 \text { do } \\
\text { "Jardim Olympig" }\end{array}$ & 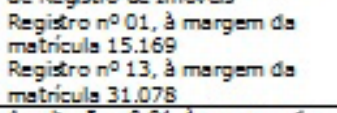 & $\begin{array}{l}\text { Muricipalidade de Sao Paula } \\
\text { Muricipalidade de Sao Paula }\end{array}$ \\
\hline públies & 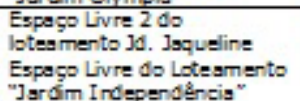 & 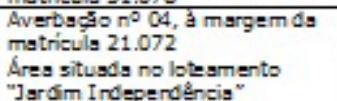 & $\begin{array}{l}\text { Muricipalidade de SIo Paula } \\
\text { Munisipalidade de Sso Paula }\end{array}$ \\
\hline
\end{tabular}

Fonte: Diagnóstico jurídico/2012. DPESP/Extrema Construções Ltda.

\subsection{O PROCESSO DE OCUPAÇÃO DAS APPS}

O assentamento se consolidou sobre dois cursos d'água, cujas nascentes estão localizadas na área onde hoje está implantado o Shopping Raposo Tavares. Os córregos se juntam ao sul, na área mais precária da comunidade, e deságuam no
13 A empresa DEOBRA S/A, constituída em 30 de julho de 1966, encontra-se regularmente registrada na Junta Comercial do Estado de São Paulo, com sede à Rua José Bonifácio n² 24, salas 81 e 82.

14 De acordo com a Junta Comercia do Estado de São Paulo, a empresa encontra-se regularmente inscrita no Cadastro Nacional da Pessoa Jurídica (CNPJ), mantendo sua sede à Rua São Bento $n^{\circ} 545,10^{\circ}$ andar, Centro, Capital (SP). Fazem parte da empresa os seguintes sócios-administradores: Enrique Michaan Chalam, Jaime Michaan Chalam, Raph Michaan Chalam e Selim Michaan Chalam.

15 De acordo com a Junta Comercial do Estado de São Paulo, possui sede na Praça da República $n^{\circ} 128,3^{\circ}$ andar, Centro, Capital (SP). A atual representação da empresa é exercida por Pedro Motta de Oliveira Castro e Maria Cecília Huet de Oliveira Castro. 


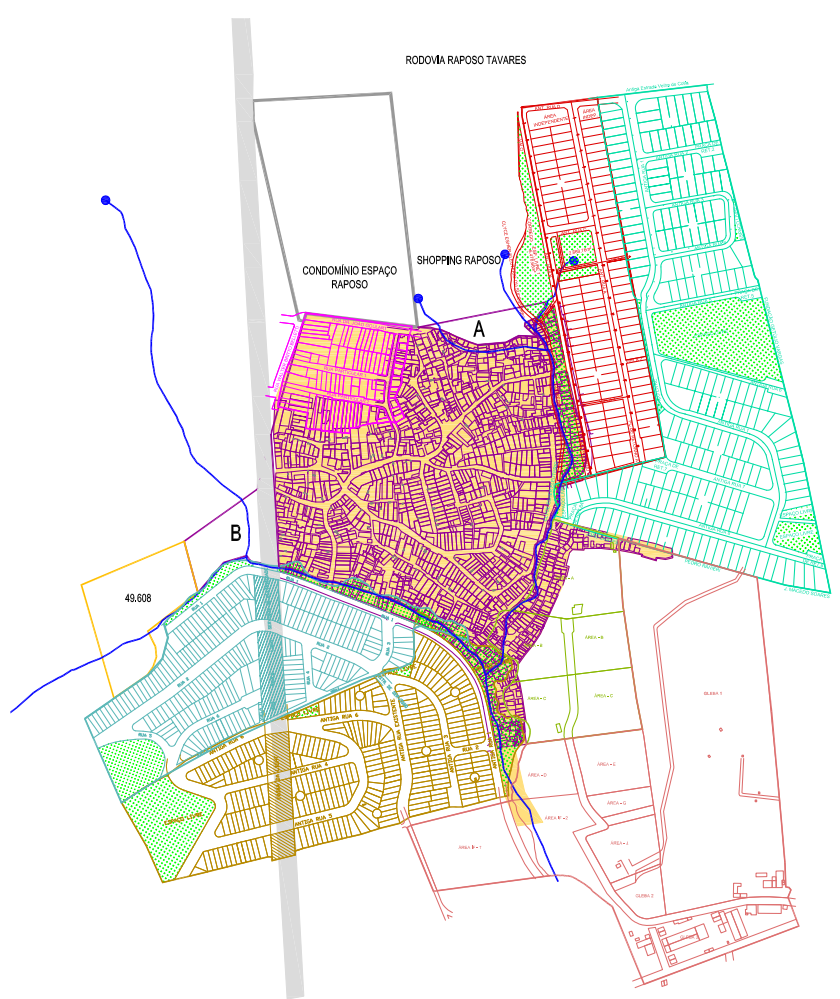

MAPA DE CONFRONTANES

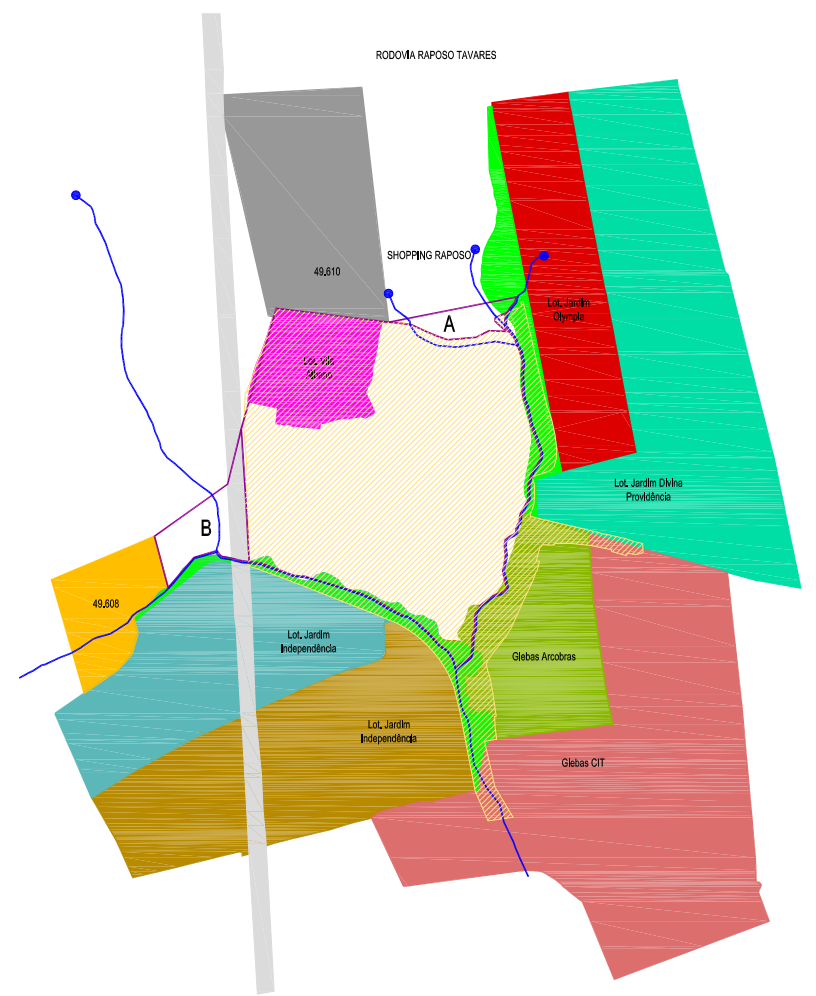

MAPA DE TTULARES DE DOMINIO

Imagem 34. 0 mapa de enquadramentos jurídicos do local e entorno mostra a disparidade entre conceituações relacionadas ao espaço. Os enquadramentos ambiental, social, urbanístico e jurídico não se relacionam. Famílias residentes em um mesmo lote, que é uma representação do universo urbanístico, poderão ter enquadramentos jurídicos diversos, pelo tempo de permanência na área, pela atividade exercida diversa da residencial e pela situação fundiária do lote, de propriedade pública ou privada. Trata-se de um promissor campo de investigação para a área jurídica, mas, em nosso caso, esses enquadramentos legais somente possuem interesse caso representem diferentes relações dos moradores com o espaço que habitam, o que não parece acontecer

\section{Legenda}

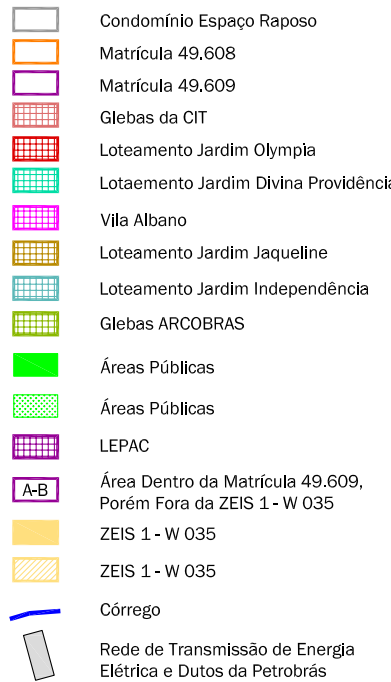

As plantas de parcelamento do Jardim Divina Providência e Jardim Olympia foram levantadas no CASE da Prefeitura Municipal de São Paulo. A planta de parcelamento da Vila Abano foi levantada no RESOLO da Prefeitura Municipal de São Paulo. Já a planta de Desmembramento de Glebas, de propriedade da CIT Engenharia e Comércio S.A., foi levantada no PARSOLO da Prefeitura Municipal de São Paulo 
Rio Pirajussara. Nas áreas mais consolidadas, foram tamponados pelos moradores e, nas áreas precárias, permanecem a céu aberto. Além das ocupações em APPs, com seus danos ambientais intrínsecos, parte da área ocupada de forma precária é caracterizada como área de risco R2 (médio), com risco de escorregamento e solapamento ${ }^{16}$.

A imagem de 2002 já indica uma ocupação consolidada e adensada, com os córregos das áreas consolidadas tamponados e o início das ocupações nas duas APPs restantes. Em 2011, as ocupações sobre APPs se intensificam, com o crescimento de construções precárias, em grande parte edificadas sobre o córrego.

Como já relatado, o shopping utiliza a água das "bicas d'água" localizadas em seu terreno para consumo, por meio de um poço de coleta instalado nas nascentes. As nascentes do curso d'água que passam sob a Rua Alessandro Bibiena aparecem em outras áreas ocupadas de forma irregular. Nota-se que a ordem das ocupações em área consolidada não segue o curso d'água, sendo comuns construções em alvenaria sobre o córrego canalizado, tornando difícil a visualização de seu percurso. O processo de canalização promovido pelos moradores transfere o problema da drenagem, configurada pelos alagamentos, para jusante, onde hoje está localizada a população mais carente do Jardim Jaqueline. Grande parte das ocupações das áreas de risco é precária, principalmente as localizadas nas APPs do trecho do córrego que permanece aberto e sobre os cursos d'água, onde o lixo e o esgoto se juntam à precariedade construtiva.

\section{A OPERAÇÃo URBANA CONSORCIADA VILA SÔNIA: MODELO DE DESENVOLVIMENTO PROPOSTO PARA A REGIÃo}

Dada a contextualização geral da área e do objeto de pesquisa, passaremos à análise do modelo de desenvolvimento indicado pela administração municipal, com suas principais propostas e possíveis desdobramentos em relação à resolução das questões habitacionais e ambientais colocadas no caso específico.

A Operação Urbana Consorciada, instrumento urbanístico previsto no Estatuto da Cidade e no Plano Diretor Estratégico de São Paulo, foi utilizada no município em diferentes gestões e contextos políticos, sendo que as aplicações mais conhecidas e teorizadas foram as Operações Urbanas Faria Lima e Águas Espraiadas. Foram adotadas pela administração municipal de São Paulo como modelo de desenvolvimento urbano, sendo originárias de uma estratégia difundida internacionalmente de atuação em áreas degradadas, dentro de um discurso de valorização da escala local de governo e da ideia de promoção de cidades globais competitivas. Os exemplos que temos de utilização desse modelo em São Paulo comprovam que o instrumento serviu à promoção de uma flexibilidade oportuna à produção e reprodução do capital e apropriação da mais-valia urbana. Também presenciamos como o uso dessa flexibilidade atribuída ao poder local muitas 
vezes pode contrariar princípios legais, com alterações de normas e regulamentos de acordo com os interesses imediatos de promotores imobiliários, em um "permanente estado de exceção" (Oliveira; Rizek, 2007), em que a exceção torna-se a regra.

A ideia básica contida no instrumento Operação Urbana Consorciada é que a criação de espaços de exceção dentro das regras que regem o crescimento da cidade poderia gerar benesses tanto para o poder público quanto para o privado. 0 poder público, por meio da negociação de uma moeda de troca estratégica, que é o potencial construtivo da terra urbana, acumularia recursos suficientes para promoção de "transformações urbanísticas estruturais, melhorias sociais e valorização ambiental"17.

\subsection{A OPERAÇÃO URBANA CONSORCIADA VILA SÔNIA (OUCVS)}

O objetivo aqui colocado é a análise das possibilidades de compatibilização entre o ordenamento legal existente em relação à área onde se situa o Jardim Jaqueline, que reconhece a questão habitacional a ser equacionada, e a flexibilização e as propostas contidas na Operação Urbana. Entende-se que a Operação Urbana anda a reboque do processo de valorização imobiliária em curso na região ao mesmo tempo em que deve promover novos processos de valorização, decorrentes das propostas contidas no plano. Dentro da Operação Urbana, o Jardim Jaqueline assume posição privilegiada em relação à realidade das favelas de São Paulo, pela perspectiva de recursos disponiveis, ao mesmo tempo em que sua estrutura social torna-se fragilizada frente ao poder avassalador de um mercado imobiliário em expansão. Dentre as propostas anunciadas, a OUCVS prevê um programa de reurbanização das ZEIS, favelas Jardim Jaqueline e Vale da Esperança.

As diretrizes urbanísticas para a Operação Urbana Vila Sônia, contidas no Plano-Referência de Intervenção e Ordenação Urbanística (PRIOU), não contrariam os objetivos enunciados pelos idealizadores das novas Operações Urbanas. De acordo com uma série de textos publicados na internet ${ }^{18}$ pela equipe da administração municipal que concebeu as propostas urbanísticas das novas Operações Urbanas, foram realizados estudos críticos a respeito dos desdobramentos das Operações em curso, buscando-se o aprimoramento da prática e novas alternativas de aplicação de um instrumento que continua sendo prioritário na visão de muitos técnicos e gestores municipais, independentemente da gestão.

No PRIOU, que deve fazer parte do projeto de lei, está delimitado o perímetro de atuação da Operação Urbana, as áreas de intervenção, objetivos e estimativas de potenciais construtivos por setores. No caso da OUCVS, os custos das obras públicas estão estimados em R\$251 milhões e a obtenção de recursos pela emissão de CEPAC, em R\$340 milhões, que deverão ser obtidos por meio da venda de um estoque total de potencial adicional de construção de $1.356 .000 \mathrm{~m}^{2}$ em
17 "Considera-se operação urbana consorciada o conjunto de intervenções e medidas coordenadas pelo Poder Público municipal, com a participação dos proprietários, moradores, usuários permanentes e investidores privados, com o objetivo de alcançar em uma área transformações urbanísticas estruturais, melhorias sociais e valorização ambiental." Estatuto da Cidade, Lei n 10.257, art. 32, parágrafo $1^{\circ}$, de 10/07/2001.

18 Os artigos foram escritos por Pedro Sales, assessor técnico da Sempla, entre 2001 e 2004; José Magalhães Jr., diretor do Departamento de Projetos Urbanos da Sempla, na mesma época; José Geraldo de Oliveira; e Marcelo Barnardini. Disponivel em: <http://www.vitruvius.com.br/ revistas/read/arquitextos/05.059/476>. Acesso em: 17 Jan. 2012. 
uma área de 673 ha. O grande mote para a OUCVS é a construção da Linha Amarela do Metrô (Linha 4) que, a exemplo das outras linhas existentes, trará grande impacto para a região onde estão as estações, do ponto de vista estrutural e de valorização imobiliária. Além da possibilidade de integração urbanística a partir da rede de transporte coletivo, a Operação Urbana tomaria partido da valorização imobiliária decorrente da implantação da nova linha.

O principio geral que justifica as Operações Urbanas do ponto de vista urbanístico, que é o adensamento de áreas providas de infraestrutura e com boas condições de acessibilidade, é apoiado por grande parte dos urbanistas, que partem do princípio que o adensamento de uma cidade compacta significa: maior acesso a uma infraestrutura consolidada associada aos centros urbanos; economia na implantação de novas infraestruturas cada vez mais distantes, que fazem parte da realidade de cidades espraiadas como São Paulo; e melhores condições de mobilidade e acessibilidade, com a proximidade entre residência e locais de trabalho. A essas vantagens, soma-se a diversidade social e de usos, por meio de regulamentações e políticas públicas específicas. Ressaltamos que esse discurso sobre a "cidade compacta", se não estiver atrelado ao conceito de cidade democrática - que deve prever, entre outras coisas, a real dimensão dos espaços livres e públicos -, pode ser facilmente apropriado pelo rolo compressor do mercado imobiliário ${ }^{19}$

Além das intenções associadas ao plano ou ao aparato técnico que acompanha uma Operação Urbana, o que determina a efetividade e as consequências de uma Operação Urbana é a conjuntura política e econômica em que o instrumento está inserido. Assim como o adensamento é importante para a vida saudável nas grandes cidades, a incorporação das diversas classes sociais nessa cidade oficial e a promoção de uma real qualidade de vida - que leve em conta hábitos diversos de apropriação do espaço urbano, que não passam pelo uso do transporte individual ou de centros de compras e centros empresariais isolados do tecido urbano - são igualmente importantes.

Dentre as novidades anunciadas para a OUCVS, a mais difundida pelos técnicos do município, e que impacta diretamente o futuro do Jardim Jaqueline, diz respeito à alteração da porcentagem arrecadada a ser utilizada na produção de habitação de interesse social:

Prevê-se a inclusão na lei que instituirá a OUCVS de dispositivo legal (inédito em relação às demais leis de OUC) estabelecendo a separação dos 30\% (no mínimo) a cada ingresso de recursos pela venda de CEPAC, para o fundo específico a ser administrado pela $\mathrm{HAB}{ }^{20}$.
19 Entendemos que o adensamento deve promover a liberação de espaços livres sem edificação de qualidade, necessários à desejada qualidade de vida nas grandes cidades.

20 Audiência Pública de apresentação da OUCVS realizada no CEU Butantã, em novembro de 2011 [grifos nossos]. Disponivel em: <http://www.slideshare.net/ pelacidadeviva/oucvssmdu20110827>. Acesso em: 29 Jul. 2013. 


\section{OPERAÇÃO URBANA CONSORCIADA VILA SÔNIA}

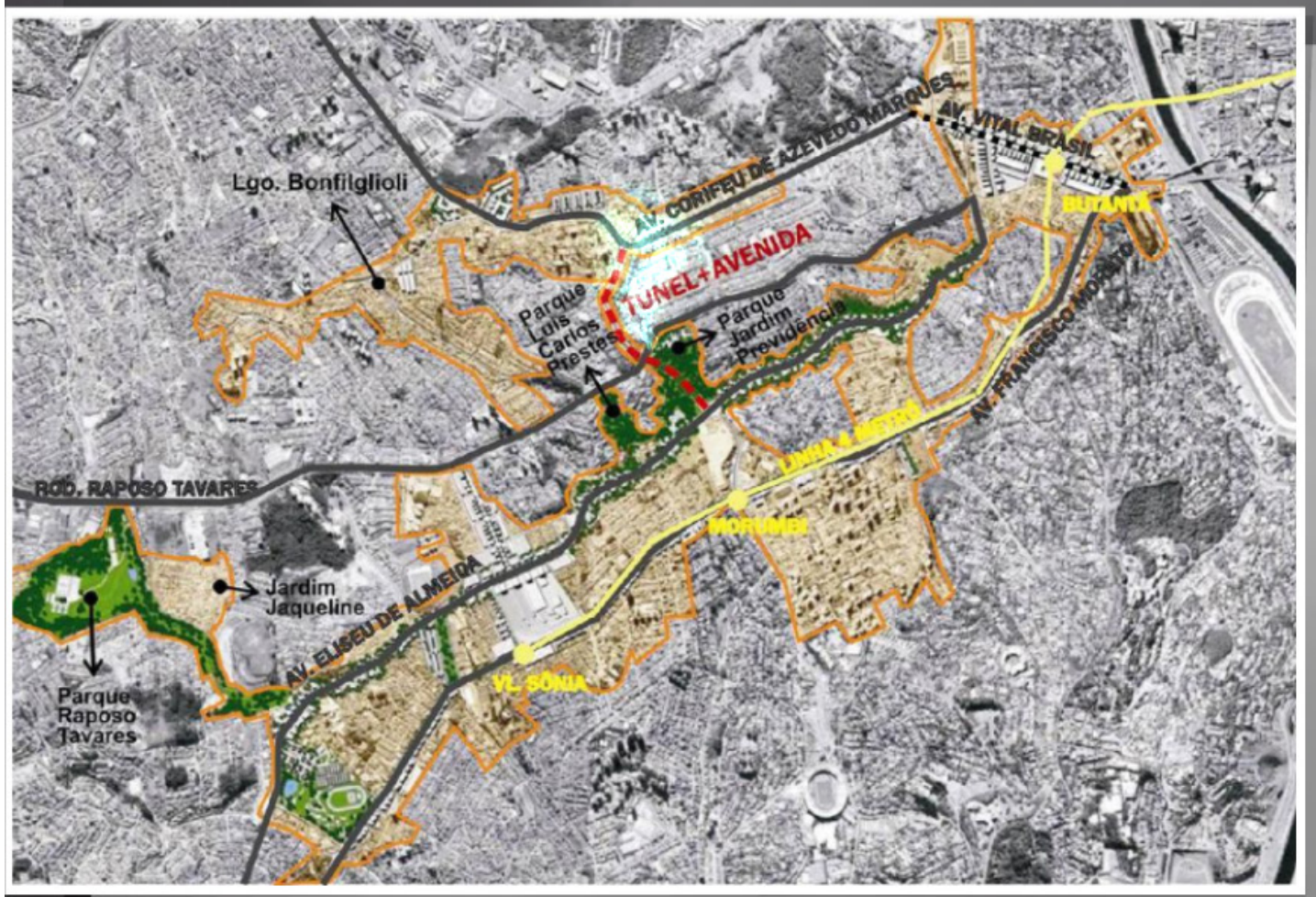

As Operações

Urbanas

Consorciadas

O

Contexto das

Áreas de

Intervenção

Urbana

O

TEORIA

PRÁTICA

O

Operação

Urbana

Vila Sônia

Butantã

O

PARTICIPE!

Imagem 35. Imagem da Operação Urbana

Vila Sônia, no folder distribuído na Audiência Pública de novembro de 2011 
Certamente essa conquista normativa vem da pressão política exercida pelos movimentos sociais e da repercussão negativa que as outras Operações Urbanas tiveram com as populações de baixa renda. Na audiência pública de apresentação da OUCVS, que contou com grande e importante presença dos moradores do Jardim Jaqueline, apesar do tema "habitação", seguido de "meio ambiente", aparecerem como prioritários na ordem de apresentação do projeto o tempo dedicado ao tema "mobilidade e sistema viário", em especial às intervenções viárias propostas, indicando maior desenvolvimento projetual reservado ao tema. As soluções apontadas para as demandas de mobilidade e acessibilidade, respaldadas por diagnósticos apresentados, priorizam as intervenções no sistema viário, onde já existe o projeto de uma ponte, uma passagem em desnível e um polêmico túnel que passaria sob o Parque da Previdência. Indagados sobre a prioridade dada ao transporte individual, os técnicos da prefeitura alegaram que tais estruturas viárias também serviriam ao transporte público. Apesar da afirmação, não foram apresentados projetos específicos em relação ao transporte público, além da interligação modal entre a nova estação de metrô e um novo terminal de ônibus. Tratando-se de prioridades, vale a pena traçar um comparativo entre gastos previstos para o sistema viário e promoção de habitação de interesse social, que, com a reserva de 30\%, atingirão somente os valores já previstos pelo Plano Municipal de Habitação da Subprefeitura do Butantã para a região21.

Vemos que a abordagem do plano de referência da Operação Urbana privilegia ações setoriais apartadas, em eixos temáticos ligados às áreas habitacional-social, paisagístico-ambiental, mobilidade e centralidade, além do adensamento, como se os eixos estruturadores previstos pelo PDE pudessem ser abordados isoladamente. De fato, o adensamento da área, que se relaciona diretamente aos interesses do setor privado na Operação Urbana, deverá subordinar os demais eixos temáticos, fazendo com que essa Operação, como as demais em andamento, corra o risco de desenvolver somente os temas de interesse do mercado imobiliário.

Será que uma avaliação crítica a respeito da aplicação das Operações Urbanas existentes seria capaz de reverter a lógica especulativa embutida em sua premissa básica, que é a venda de CEPACs? Seria possível utilizar tal instrumento para a real efetivação de melhorias sociais e valorização ambiental previstos em seu conceito, ou a ideologia do "bom para todos" continuaria perpetuando a lógica de exclusão territorial da população de baixa renda? Esse raciocínio pode ser transposto para o caso do Jardim Jaqueline que, se for beneficiado pelos recursos gerados pela Operação Urbana, pode ganhar um projeto urbanístico dito "sustentável", como diversos outros existentes, mas teria a garantia de um projeto socialmente sustentável? Vale lembrar que a OUCVS foi paralisada em 2012, em decorrência de decisão judicial que reconheceu a ausência de participação popular no processo de construção dos planos e projetos propostos ${ }^{22}$. A decisão
210 Plano Municipal de Habitação prevê a necessidade de $\mathrm{R} \$ 130$ milhões para atendimento da demanda habitacional da subprefeitura, a ser atendida no quarto quadriênio. Somente a conexão viária norte-sul (túnel) deverá custar R\$ 272 milhões, de acordo com informações da apresentação da OUCVS, em agosto de 2011.

22 "[...] 0 principio da participação popular na gestão democrática das cidades é imprescindivel porque consolida um Estado Democrático e Social de Direito Brasileiro. Portanto, defiro a liminar para sustar toda e qualquer tramitação administrativa e legislativa sem que se garanta a efetiva participação da população e de associações representativas dos vários segmentos da comunidade na formulação, execução e acompanhamento de planos, programas e projetos de desenvolvimento urbano relacionados à Operação Urbana Consorciada Vila Sonia [...]." Trecho da liminar concedida pelo Exmo. Dr. Marcos de Lima Porta, Juiz da $5^{a}$ Vara da Fazenda Pública da Capital. 
vem de demanda encaminhada pela Associação de Moradores do Butantã, onde os moradores do Jardim Jaqueline ou de outras favelas inseridas no perímetro da Operação Urbana não tiveram qualquer participação. A respeito da pulverização da esfera participativa, com o crescimento dos grupos e das formas de participação, podemos ver que a participação popular, no caso da OUCVS, se resume a interesses específicos, relacionados ao padrão de moradia de uma classe média avessa ao processo de verticalização decorrente da Operação Urbana e que conta com quadros técnicos especializados no apoio às suas reivindicações. Os moradores das favelas, sem o respaldo da "técnica competente" e o apoio de uma opinião pública sempre disposta a encampar as "causas das pessoas de bem" e rechaçar as demandas das baixas rendas, associadas à degradação do meio, dificilmente conquistam decisão similar no judiciário.

\subsection{PARQUES LINEARES PROPOSTOS}

Pensando em prováveis cenários para as APPs existentes no Jardim Jaqueline, a Operação Urbana traz planos de intervenção para APPs, que podem ser considerados como modelos a serem reproduzidos, dadas as aproximações entre os diversos projetos. Para o Jardim Jaqueline, existe um plano de parque linear que removeria todas as moradias ao longo da Rua Alessandro Bibiena.

Buscando um engajamento nas questões que envolvem qualidade de vida e meio ambiente, a OUCVS propõe a criação de parques lineares ao longo de alguns córregos tributários do Rio Pirajussara. Além da clara utilização da qualidade paisagística como potencial de valorização do meio, pode-se ver que os projetos existentes reproduzem a ideologia utilizada quando se fala em preservação ambiental dentro do discurso da sustentabilidade: remoção de habitações de baixa renda e legitimação de uma cidade legal igualmente construída sobre os rios urbanos.

O PRIOU da Operação Urbana indica a implantação de infraestrutura verde ligada aos espaços públicos, com caminhos verdes, que nada mais são do que a recuperação paisagística de avenidas, parques lineares ao longo dos córregos da Água Podre e Itararé e recuperação paisagística do Parque Raposo Tavares. O Plano Regional Estratégico (PRE) da Subprefeitura do Butantã prevê a delimitação de Áreas de Intervenção Urbanas (AIU) que possibilitam a aplicação de diversos instrumentos urbanísticos para a criação de parques lineares e ampliação de áreas permeáveis de fundo de vale, entre outros ${ }^{23}$.

O único parque linear que conta com projeto preliminar situa-se ao longo do córrego Itararé, onde serão adotadas as chamadas "vias-parque" que seriam variações das mesmas avenidas de fundo de vale, com a conciliação de estratégias que dizem respeito à preservação ambiental, como uso de pisos drenantes, arborização e aparatos de lazer - ciclovias, decks de
230 Laboratório de Habitação e Assentamentos Humanos da FAU-USP elaborou pesquisa e análise de aplicação de instrumentos em planejamento urbano ambiental no município de São Paulo, encomendada pela Secretaria do Verde e Meio Ambiente da prefeitura do município de São Paulo, em que elaborou estudo de viabilidade para a implementação de Áreas de Intervenção Urbana (AIUs) voltadas para a implantação de parques lineares. Disponivel em: <http://www. usp.br/fau/depprojeto/labhab/pesquisa/ pq0602.html>. Acesso em: 18 Jan. 2012. 


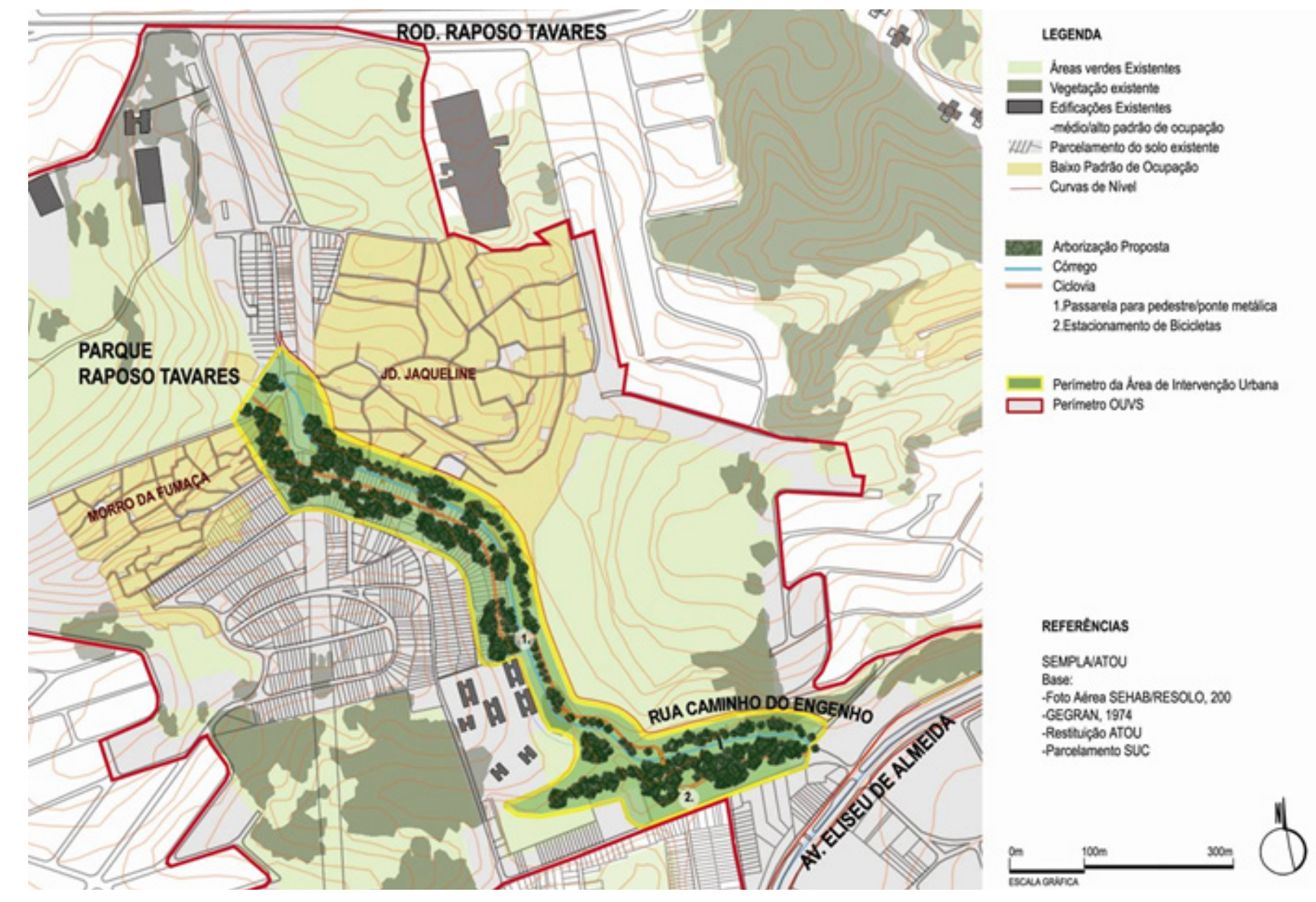

madeira, bancos e equipamentos de ginástica. A favela que ocupa as margens do córrego será removida e seus moradores realocados em conjuntos habitacionais a serem construídos nas proximidades.

Considerando a estratégia do ponto de vista físico, a implantação de parques lineares segue diretrizes do PDE, que institui como elementos estruturadores territoriais a rede hídrica, juntamente com a rede viária, a rede de transporte público coletivo e os polos de centralidades. Porém, deve-se ressaltar a importância da implantação não somente de parques
Imagem 36. Fonte: Apresentação da Operação Urbana Vila Sônia, Dezembro de 2007- PMSP. Disponivel em: http://www. slideshare.net/pelacidadeviva/operaourbana-vila-snia-sempla-2007 
lineares, mas de uma ação articulada de preservação e recuperação dos fundos de vale, que devem contar com educação ambiental, saneamento básico, reserva de áreas permeáveis e controle de drenagem em toda a bacia. Tal controle, que diz respeito à escala da microdrenagem, com rebatimentos da macrodrenagem, deve contar com rigorosa fiscalização para garantir, entre outras ações estratégicas, a necessária reserva de área verde por lote.

Vale lembrar que as margens dos córregos não foram ocupadas por falta de leis que regulem a ocupação de córregos em área urbana. Do Código Florestal, em sua alteração de 1989, à Lei Federal 6766/79, as margens dos cursos d'água contam com faixa de preservação de, pelo menos, 15 metros. Além das discussões sobre a pertinência da aplicação do Código Florestal em área urbana, é importante ressaltar as diferentes abordagens em relação às formas de ocupação das APPs urbanas. É notória a responsabilização das áreas de moradia precária como degradantes do meio ambiente, em detrimento de empreendimentos que fazem parte da cidade legal, que passam despercebidos pela opinião pública como elementos igualmente impactantes.

\section{LUTA POR DIREITOS}

\subsection{TRAJETÓRIA RUMO À REGULARIZAÇÃO FUNDIÁRIA}

O projeto de regularização fundiária do Jardim Jaqueline faz parte da luta de seus moradores, representados por sua Associação, pelo reconhecimento da posse da área. A luta por direitos, que teve início em 2000, passa por mais um capítulo, o da regularização fundiária, que deve garantir o direito de propriedade a seus ocupantes. A Associação de Moradores busca a regularização da área há pelo menos 12 anos, quando procurou o município e recebeu promessas de regularização que se perderam a cada mudança de gestão partidária. Com a paralisação do processo na prefeitura, as lideranças locais continuaram a pressionar o poder público, encaminhando o caso à Defensoria Pública do Estado de São Paulo.

A Defensoria Pública assumiu o processo de acordo com as premissas da Regularização Fundiária Plena, idealizada pelas equipes técnicas do Ministério das Cidades, em um contexto de retomada das políticas públicas voltadas à habitação de baixa renda. De acordo com essa premissa, o local receberá uma intervenção que tem como objetivos: a regularização fundiária; a apresentação de estudos que apontem caminhos para sua regularização urbanística; e o desenvolvimento de uma série de atividades sociais, com objetivo de fortalecimento do poder local, de conscientização dos moradores a respeito de seus direitos e deveres e de compartilhamento de ideias e debates que se identifiquem com questões relacionadas às intervenções urbanísticas. 
O contexto de conquistas dos moradores do Jardim Jaqueline somente pode ser entendido a partir da atuação e força de seus representantes, com destaque para a presidente da Associação, Elisabete Silva, presente diariamente, há mais de 12 anos, em todos os acontecimentos que dizem respeito ao lugar, de assembleias e reuniões com moradores aos eventos promovidos pela prefeitura municipal, como a apresentação do Plano Municipal de Habitação e da Operação Urbana Vila Sônia. Junto com Elisabete Silva, Nívea Maria da Silva dos Santos Miranda cumpre um importante papel de articulação política na Associação, com participação ativa em todos os encontros promovidos pela prefeitura, com pleno conhecimento de todas as questões que afetam direta ou indiretamente o Jardim Jaqueline. Nívea é uma importante referência local, hoje eleita como representante do Conselho Tutelar do Butantã. O reconhecimento dessas lideranças é importante para o entendimento do processo de conquistas, que podemos chamar de pontuais e paliativas, mas que são de extrema importância dentro do universo referencial dos moradores locais. Essas relações estabelecidas com o poder público, muitas vezes de natureza clientelista, também indicam o potencial de atuação para futuras transformações, que podem ser estruturais, principalmente em relação aos impactos da futura operação urbana na área. Ainda que essas lideranças não façam parte dos movimentos sociais tradicionais urbanos, reunidos em torno do ideal da reforma urbana, pode-se afirmar que possuem os referenciais e instrumentos de luta desses movimentos, como o engajamento político e a articulação em rede com outras lideranças locais.

A atuação dessas personalidades femininas na favela também traz à tona uma realidade existente em grande parte das favelas e comunidades de baixa renda nas grandes cidades: a do protagonismo feminino nas lutas por reconhecimento nas periferias urbanas. Como o diagnóstico social efetuado no projeto para regularização fundiária do Jardim Jaqueline encontrou um equilíbrio entre homens e mulheres residentes, chama atenção o protagonismo exercido pelas lideranças e a predominância feminina nas reuniões realizadas ao longo do processo.

A delimitação da área que passará pelo processo de regularização fundiária é fruto da articulação das lideranças locais. A favela vizinha, o Vale da Esperança, cuja liderança se afastou politicamente das lideranças do Jardim Jaqueline, não foi encaminhada como demanda à Defensoria Pública. As demandas de regularização das duas favelas caminhavam juntas, quando a liderança do Vale da Esperança alterou sua filiação partidária em uma das mudanças de gestão municipal. Desde então, essa liderança deixou de participar ativamente das demandas de seu local de influência, e a Associação de Moradores do Jardim Jaqueline vem conquistando espaço político junto aos moradores do Vale da Esperança, que pretendem passar pelo mesmo processo de regularização realizado no Jardim Jaqueline ${ }^{24}$.

Nos termos do Estatuto da Cidade ${ }^{25}$, o processo de regularização fundiária plena é entendido como um conjunto
24 Uma empresa especializada em regularização fundiária estaria trabaIhando no Vale da Esperança/Morro da Fumaça. Uma moradora confirmou que a associação de moradores local está em processo de negociação com a empresa Terra Nova.

25 Em 2001, o Estatuto da Cidade regulamentou os artigos 182 e 183 da Constituição Federal, estabelecendo os instrumentos de gestão democrática das cidades e de regularização fundiária que permitem efetivar o direito à cidade e à moradia urbana. 
de medidas jurídicas, urbanísticas, ambientais e sociais, promovidas pelo poder público por razões de interesse social. Essas medidas devem garantir a adequação dos assentamentos informais, de modo a assegurar o direito social à moradia e a função social da propriedade e da cidade. A Lei N 11.977, de 7 de julho de 2009, que institui o programa "Minha Casa Minha Vida", prevê a regularização fundiária de assentamentos irregulares ocupados, predominantemente, por população de baixa renda ${ }^{26}$. Na regularização de interesse social, os parâmetros urbanísticos e ambientais poderão ser flexibilizados, considerando-se a ocupação consolidada.

De acordo com essa lei, o projeto de regularização fundiária deve apresentar: (i) as áreas ou lotes a serem regularizados e, se houver necessidade, as edificações que serão realocadas; (ii) as vias de circulação existentes ou projetadas e, se possível, as outras áreas destinadas a uso público; (iii) as medidas necessárias para a promoção da sustentabilidade urbanística, social e ambiental da área ocupada, incluindo as compensações urbanísticas e ambientais previstas em lei; (iv) as condições para promover a segurança da população em situações de risco considerado o disposto no parágrafo único do art. $3^{\circ}$ da Lei $n^{\circ}$ 6.766/197927; e (v) as medidas previstas para adequação da infraestrutura básica.

Em relação à regularização urbanística, o plano de urbanização de cada ZEIS será estabelecido por decreto do Poder Executivo Municipal e, de acordo com o Art. 175 da Lei n 13.430/2002, deverá prever:

(i) parâmetros urbanísticos para o parcelamento, uso e ocupação do solo e instalação de infra-estrutura [sic] urbana respeitadas as normas pertinentes; (ii) diagnóstico da ZEIS que contenha no mínimo: análise físico-ambiental, análise urbanística e fundiária e caracterização socioeconômica da população residente; (iii) os projetos e as intervenções urbanísticas necessárias à recuperação física da área, incluindo, de acordo com as características locais, sistema de abastecimento de água e coleta de esgotos, drenagem de águas pluviais, coleta regular de resíduos sólidos, iluminação pública, adequação dos sistemas de circulação de veículos e pedestres, eliminação de situações de risco, estabilização de taludes e de margens de córregos, tratamento adequado das áreas verdes públicas, instalação de equipamentos sociais e os usos complementares ao habitacional; (iv) instrumentos aplicáveis para a regularização fundiária; (v) forma de participação da população na implementação e gestão das intervenções previstas; (vi) fontes de recursos para a implementação das intervenções; e (vii) plano de ação social28.

De acordo com a Lei n 11.977/09, a regularização fundiária pode ser realizada em etapas e os municípios passam a ter competência para a aprovação do projeto de regularização urbanística e ambiental, se contarem com conselho próprio
26 "Art. 47. Para efeitos da regularização fundiária de assentamentos urbanos, consideram-se:

VII - regularização fundiária de interesse social: regularização fundiária de assentamentos irregulares ocupados, predominantemente, por população de baixa renda, nos casos:

a) em que a área esteja ocupada, de forma mansa e pacífica, há, pelo menos, 5 (cinco) anos; b) de imóveis situados em ZEIS; ou c) de áreas da União, dos Estados, do Distrito Federal e dos

Municípios declaradas de interesse para implantação de projetos de regularização fundiária de interesse social [...]."

27 "Não será permitido o parcelamento do solo: I - em terrenos alagadiços e sujeitos a inundações, antes de tomadas as providências para assegurar o escoamento das águas; II - em terrenos que tenham sido aterrados com materia nocivo à saúde pública, sem que sejam previamente saneados; III - em terreno com declividade igual ou superior a $30 \%$ (trinta por cento), salvo se atendidas exigências específicas das autoridades competentes; IV - em terrenos onde as condições geológicas não aconselham a edificação; V - em áreas de preservação ecológica ou naquelas onde a poluição impeça condições sanitárias suportáveis, até a sua correção." Parágrafo único do Art. $3^{\circ}$ da Lei $n^{\circ} 6.766 / 79$

28 "No caso de ZEIS cujos limites estejam compreendidos dentro dos perímetros de Operações Urbanas Consorciadas fica 
e órgão ambiental capacitado. Ainda de acordo com a Lei, as ocupações em áreas de preservação permanentes poderão ser regularizadas, de acordo com o disposto no Art. 54:

Art. 54. 0 projeto de regularização fundiária de interesse social deverá considerar as características da ocupação e da área ocupada para definir parâmetros urbanísticos e ambientais específicos, além de identificar os lotes, as vias de circulação e as áreas destinadas a uso público.

§1 O Município poderá, por decisão motivada, admitir a regularização fundiária de interesse social em Áreas de Preservação Permanente, ocupadas até 31 de dezembro de 2007 e inseridas em área urbana consolidada, desde que estudo técnico comprove que esta intervenção implica a melhoria das condições ambientais em relação à situação de ocupação irregular anterior ${ }^{29}$.

A grande questão colocada a respeito de um processo de regularização fundiária promovida por um ente federativo diferente da municipalidade diz respeito à sua desvinculação em relação à regularização urbanística, que seria uma atribuição do município. De acordo com posição do Ministério das Cidades, assumida em publicação sobre regularização fundiária sustentável, "a regularização fundiária plena é uma meta a ser alcançada, mas não deve ser um obstáculo à regularização fundiária jurídica, na qual são reconhecidos os direitos reais"30.

Ao contrário das dificuldades dos municípios com os cartórios de registro de imóveis e com a irregularidade jurídica de grande parcela do território urbano, um ente jurídico trabalhando com a irregularidade da terra urbana pode ser um facilitador na resolução de questões legais em torno da propriedade fundiária, porém não é capaz de afetar a estrutura física de um parcelamento irregular, que se adensa a cada dia e com áreas que necessitam de obras urgentes, seja pelas condições precárias de moradia ou pelo risco a que estão submetidas.

Partindo desse princípio, podemos indicar a grande diferença entre os termos "segurança na posse" e "moradia digna", termos comumente citados em processos judiciais que envolvem regularização fundiária ou reintegração de posse. A garantia jurídica dada em relação à segurança na posse não se relaciona ao conceito de moradia digna, que passa necessariamente por alterações na estrutura física da habitação e de seu contexto urbano. No caso do Jardim Jaqueline, apesar do processo de regularização fundiária estar em andamento, não existe sinalização por parte do município de que serão realizadas obras no local, além da previsão de implantação do parque linear, vinculado à OUCVS, ainda sem projeto oficial. definido: I- a aplicação dos instrumentos, diretrizes e elementos previstos e estabelecidos nesta seção, serão implementados por meio de leis específicas que regem as Operações Urbanas Consorciadas; II - o percentual de HIS a ser produzido, fixado na lei específica de Operação Urbana, poderá ser parcialmente atendido nas ZEIS com recursos provenientes da Operação Urbana; III - o coeficiente de aproveitamento máximo é o definido para a Operação Urbana na qual a ZEIS está inserida, aplicando-se os demais indices, parâmetros e disposições estabelecidos para as ZEIS; IV - a concessão do direito de construir acima do coeficiente de aproveitamento básico, até o coeficiente máximo definido, será gratuita para a produção de HIS e para HMP com até $50 \mathrm{~m}^{2}$ de área útil total, por unidade habitacional." Art. 173 da Lei ${ }^{\circ}$ $13.430 / 2002$.

29 Art. 173 da Lei n 13.430/2002.

30 Lei Federal n 11.977/2009 (BRASIL, 2010) 
Muito se discute no meio jurídico e entre urbanistas sobre as vantagens e desvantagens de um processo de regularização fundiária que atribui direitos plenos de propriedade aos moradores de assentamentos irregulares. Peter Marcuse defende que o direito pleno de propriedade não é a melhor maneira de se garantir a segurança da posse para os despossuídos. Para o autor, além de fortalecer relações de poder estabelecidas, baseadas na propriedade, tal modelo introduz no setor habitacional relações plenas de mercado, em conformidade com a matriz econômica estabelecida, além de contribuir para a desagregação social, por meio da individualização dos interesses de cada membro da comunidade. Além disso, cita as obrigações adquiridas em um processo de regularização, como taxas e subordinação às leis urbanísticas, que os pobres não poderiam assumir.

Citando a legislação brasileira, que considera única na vinculação da propriedade à sua função social, o autor propõe o atrelamento direto das disposições legais que garantem a função social da propriedade ao Plano Diretor do município, destinando as terras urbanas àqueles que a ocupam e estabelecendo critérios para sua posse. Nesse sentido, o autor previne que a simples aplicação de uma "clausula de função social" que limitaria os direitos de propriedade, aliado ao reconhecimento pleno dos futuros proprietários do valor de troca de mercado de suas propriedades, inviabilizaria a proposta de segurança da posse aos despossuídos dos centros urbanos. De acordo com a experiência existente em relação à normativa brasileira, pode-se afirmar que a simples criação de instrumentos que limitam o direito de propriedade da terra não garante a função social da propriedade.

Para Marcuse, um sistema alternativo de direito deveria focar no direito de uso em detrimento do direito de propriedade, o que já está presente em certas determinações, como a da Constituição Brasileira, que considera a habitação como direito fundamental. Apesar do aparato jurídico existente, o autor constata que o reconhecimento da questão social a ser enfrentada a partir das disposições legais não resolve a questão, na medida em que os principais problemas a serem enfrentados são de ordem política e de política pública. Nesse sentido, lança a provocação:

Se as leis não ajudam a prover a segurança da posse para os despossuídos, é melhor que elas sejam mal implementadas e confusas do que claras e bem implementadas. 0 resultado será, então, deixar o problema da segurança da posse a cargo das forças políticas; e levantar a questão da segurança da posse como uma questão política e não como uma questão técnica-legal (MARCUSE, 2008: 18) 
Apesar da constatação de que as leis não vêm contribuindo para a garantia da segurança da posse para os habitantes de baixa renda das áreas metropolitanas, pelo menos não na escala esperada, dado o tempo de vigência do aparato legal brasileiro, que trouxe importantes garantias legais, afirmar que as leis não ajudam é um equivoco frente ao histórico de pequenas grandes conquistas alcançadas a reboque das conquistas normativas.

Deixar o problema a cargo das forças políticas pode se mostrar inovador, de acordo com contextos políticos específicos, ou avassalador, como podemos ver nos exemplos de remoções forçadas de populações de baixa renda, promovidas pelo município de São Paulo, que por vezes, raras vezes, encontra a resistência do judiciário. O que se coloca é que as leis fazem parte do jogo de poder em torno do ambiente construído e, se a indefinição pender para o lado dos mais fracos, não existe força política, principalmente a relacionada aos movimentos sociais, capaz de conter o avanço das forças hegemônicas que dominam o cenário político das grandes cidades, como o mercado imobiliário, em um cenário sem garantias legais.

Mike Davis também critica a regularização fundiária de assentamentos de baixa renda, colocando como pontos negativos o aumento de despesas com as tributações assumidas e a quebra de solidariedade entre os moradores, divididos entre proprietários e não proprietários. Ermínia Maricato, no Posfácio do livro de Davis, Planeta Favela (2006), contraria a visão do autor a respeito dos processos de regularização fundiária, lembrando que muitas de suas críticas carecem de contextualizações históricas e geográficas. No Brasil, a urbanista lembra-se da luta de movimentos sociais pela regularização fundiária de assentamentos informais, que culminou com a aprovação do Estatuto da Cidade e da Medida Provisória 220, que abriram espaço para propostas de regularização fundiárias no Brasil. Apesar da regulamentação, existem poucos casos efetivados, devido à resistência da sociedade brasileira a novas restrições normativas à propriedade privada, onde se destaca o conservadorismo do judiciário. Para Maricato, somente o preconceito arraigado em nossa formação social pode explicar esse fato.

Dado o contexto do Jardim Jaqueline, admite-se que a principal consequência da iniciativa não está em seu resultado final, que será a regularização das famílias que residem no local, mas no processo de articulação da população local em torno de questões que dizem respeito aos seus interesses imediatos, que serão afetados caso a Operação Urbana Vila Sônia seja aprovada. É significativo dentro de um processo de regularização fundiária o entendimento de que o processo somente estará finalizado quando o município realizar obras de urbanização no local e a clareza de que tais obras são um direito dos moradores e não um favor político de uma gestão específica. A pesquisa de Laura Bueno sobre exemplos existentes de regularização fundiária indica que, mais do que os investimentos públicos em obras de urbanização, a simples perspectiva 
de regularização fundiária induz o aquecimento do mercado imobiliário das favelas urbanizadas. Porém essa perspectiva de valorização, que pode levar ao processo de substituição de moradores, pode ser relativizada pelo processo de urbanização, que pode fortalecer a rede de solidariedade local, por meio da melhoria de qualidade de vida e inserção socioeconômica.

De acordo com a pesquisadora ${ }^{31}$, o objetivo de um processo de regularização deve ser a permanência da população na área, com investimentos em urbanização, que comprovadamente "têm conseguido atingir diretamente os segmentos mais facilmente excluídos do processo do crescimento econômico" (BUENO, 2000: 249). É notório, após processos de urbanização, a melhoria das moradias pelos próprios moradores, com ampliação de áreas e inclusão de novos acabamentos. No Jardim Jaqueline, o simples recapeamento das vielas levou os moradores a deslocar as caçambas de lixo para outros locais da favela ${ }^{32}$. De acordo com Ermínia Maricato,

essas experiências, urgentes e inadiáveis, ampliam a cidadania, mas não atingem as raízes do processo de urbanização excludente, verdadeiro motor de produção contínua de favelas. Ele exige medidas mais amplas. 0 primeiro passo é criar consciência social sobre a dimensão e a importância do problema trazendo para a luz do dia uma realidade que é oculta pelo desconhecimento ${ }^{33}$.

A realidade apontada por Maricato diz respeito a esse contexto que procuramos exemplificar, em que o interesse social está subordinado aos interesses privados, expressos pelo capital imobiliário no caso das Operações Urbanas em geral, e que podem se concretizar na Operação Urbana onde está inserido o Jardim Jaqueline.

\subsection{A LUTA CONTINUA: CAMINHOS PARA A REGULARIZAÇÃO URBANÍSTICA}

Um processo de regularização fundiária pode tramitar durante anos no judiciário e, enquanto isso, a dinâmica urbana e social do Jardim Jaqueline não conhecerá qualquer espécie de restrição urbanística ou acompanhamento social por parte do município. A permanência de uma configuração morfológica compatível com o trabalho técnico que foi realizado entre 2011 e 2012 depende somente do reconhecimento por parte dos moradores de que a conformação de suas propriedades, aceita juridicamente, deverá coincidir com as medições efetuadas no local e que a permanência da configuração atual dos lotes é uma das garantias de propriedade para eles. Sem um projeto de urbanização concomitante aos trabalhos de regularização fundiária, parece complicado acreditar em um congelamento da área no decurso do processo de regularização
31 A autora utilizou análise dos dados de pesquisa em oito favelas, tabulados no trabalho de Helena Menna Barreto. SILVA, Helena Menna Barreto. Programas de Urbanização e desenvolvimento do mercado em favelas brasileiras. LINCOLN INSTITUTE OF LAND PO-

LICY, 2000. Disponivel: < http://www. lincolninst.edu/pubs/701_Programas-de-urbaniza\%C3\%A7\%C3\%A30-e-desenvolvimento-do-mercado-em-favelas-brasileiras>. Acesso em: 20 Ago. 2013.

32 Tal iniciativa criou outros problemas, como o acúmulo de lixo nas ruas principais, que passaram a suportar todo o lixo gerado pelas vielas.

33 MARICATO, Ermínia. Favelas: um universo gigantesco e desconhecido. Disponivel em: <http://www.usp.br/fau/ depprojeto/labhab/biblioteca/textos/ maricato_favelas.pdf $>$. Acesso em: 29 Jul. 2013. 
fundiária. Pensando nessas dificuldades e em outras questões de ordem técnica que surgiram ao longo do processo, a Defensoria Pública estuda, junto à Secretaria de Habitação do município, a regularização da área por meio do instrumento de Demarcação Urbanística ${ }^{34}$.

Por tratar-se de ZEIS 1, é obrigação do poder público construir um Plano de Urbanização para a área, que deverá ser efetivado mediante a formação de um Conselho Gestor ${ }^{35}$ formado por representantes dos moradores e pelo Poder Público, que deverá formular propostas e decidir a respeito de eventuais mudanças normativas em relação à ZEIS.

Para o futuro projeto de regularização urbanística, o poder público contará com levantamento planialtimétrico e planta de parcelamento do solo já executados, além de uma proposta urbanística para a área, executada pela empresa contratada pela Defensoria Pública, que foram encaminhados à Secretaria Municipal de Habitação. Mesmo que a proposta apresentada não configure nenhuma responsabilidade do município na sua execução, representa um esforço de incorporação dos moradores do Jardim Jaqueline no processo de elaboração do diagnóstico que deu origem à proposta, fato que a torna uma tentativa de se pensar os problemas locais a partir de levantamentos técnicos associados aos desejos dos próprios moradores. Ignorar tal trajetória seria ignorar um processo de mobilização dos moradores, importante para a efetivação de um futuro Conselho Gestor, fruto dessa articulação, a ser consolidado na área da ZEIS do Jardim Jaqueline.

A mobilização dos moradores e de suas lideranças também será importante para a disputa por áreas livres do entorno, próprias para as realocações necessárias em relação às áreas precárias e cursos d'água. Como sabemos, das cinco áreas demarcadas como ZEIS 2 dentro do perímetro de administração da Subprefeitura do Butantã, duas delas foram ocupadas por moradias de classe média e os vazios urbanos próximos, dentro de uma Operação Urbana, serão disputados pelo mercado residencial de médio e alto padrão. Nesse contexto, se a população interessada não for atuante no processo de reivindicações de seus direitos, os terrenos restantes serão ocupados exclusivamente pelas faixas de renda que interessam ao setor imobiliário em expansão.

O que uma intervenção na área deve considerar? Não se trata somente de melhoria das condições ambientais, mas principalmente do reconhecimento da relação dos moradores com a paisagem, estilos de vida e percepções do meio, entendido como uma melhoria da qualidade de vida, que se confunde com a chamada melhoria ambiental, por meio do reconhecimento das identidades e práticas locais. O contato com o local leva à constatação de que o Jardim Jaqueline não é somente um dado estatístico. Apesar da importância que as estatísticas e as análises estruturais possuem para a delimitação de políticas públicas e escolha de prioridades, o entendimento das dinâmicas locais, próprias de um conjunto
34 "A demarcação urbanística é a delimitação de uma área ocupada para fins habitacionais, de domínio público ou privado, por meio da identificação de seus limites, confrontantes, área de superfície e localização, para a realização de procedimentos de regularização fundiária de interesse social" (BRASIL, 2010).

35 Composto por representantes dos atuais ou futuros moradores e do Executivo, que deverão participar de todas as etapas de elaboração do Plano de Urbanização e de sua implementação. Parágrafo $1^{\circ}$ do Art. 175 da Lei n ${ }^{\circ}$ $13.430 / 2002$. 
específico de moradores é fundamental para o reconhecimento das relações de pertencimento que esses moradores estabelecerão com o projeto a ser desenvolvido no local.

Nesse sentido, uma remoção ou a criação de um parque linear não pode ser considerada como impactante somente em relação às famílias removidas, mas em relação a todo um conjunto de futuros usuários do local, ou de futuros "invasores", de acordo com o projeto de inclusão a ser realizado.

\section{O PROJETO E O RECONHECIMENTO DE UMA IDENTIDADE}

Ainda sem propostas por parte da prefeitura e sem a possibilidade de vislumbrar um projeto participativo para a favela, os moradores foram surpreendidos com trabalhos desenvolvidos em uma disciplina de graduação da Faculdade de Arquitetura e Urbanismo da Universidade de São Paulo (FAU-USP). Uma das arquitetas ${ }^{36}$ que fez parte da equipe que desenvolveu os trabalhos técnicos para regularização fundiária para a Defensoria Pública levou o caso Jardim Jaqueline até as pranchetas de uma disciplina de Planejamento Urbano da Universidade, abrindo nova possibilidade de reflexão às lideranças e aos moradores do bairro.

Uma das propostas de intervenção para a favela, derivada da disciplina, trouxe entusiasmo e esperança às lideranças que foram consultadas a respeito da pertinência do desenho apresentado. Mesmo entendendo a inviabilidade de aplicação integral do desenho que foi colocado em sua frente, uma das lideranças, de forma madura e consciente, lamentou o fato da municipalidade nunca ter pensado em nada para eles (moradores) em tantos anos de lutas e reivindicações. Apesar de saber que não se tratava de uma proposta facilmente executável, ela ponderou que tal iniciativa representava uma possibilidade, uma esperança de futuro, e que o esforço dos alunos havia trazido algo muito valioso à comunidade, que era a "possibilidade de futuro".

Tal fato também abriu a possibilidade de se discutir a respeito do preconceito em relação ao desenho da favela e da diferença entre o traçado espontâneo característico das favelas e a ausência de infraestrutura básica.

Apesar do processo de estudos sobre intervenções em favelas indicar que a reestruturação radical do espaço não é a melhor solução na maioria dos casos analisados, os moradores da cidade formal e parte dos gestores públicos ainda consideram o desenho da favela como um contraponto à modernidade dos conjuntos habitacionais, que seria a solução mais adequada, do ponto de vista da salubridade dos espaços e da "paisagem" (considerada como imagem). A favela urbanizada que segue um desenho formal, ortogonal e com os devidos distanciamentos de vias de circulação são comparadas aos
36 Heloisa Diniz de Rezende foi monitora PAE da disciplina "Desenho Urbano e projeto dos espaços da Cidade (AUP 274)". A disciplina contou com uma visita dos alunos ao Jardim Jaqueline, que fez parte das opções disponiveis para elaboração de uma proposta de intervenção. 

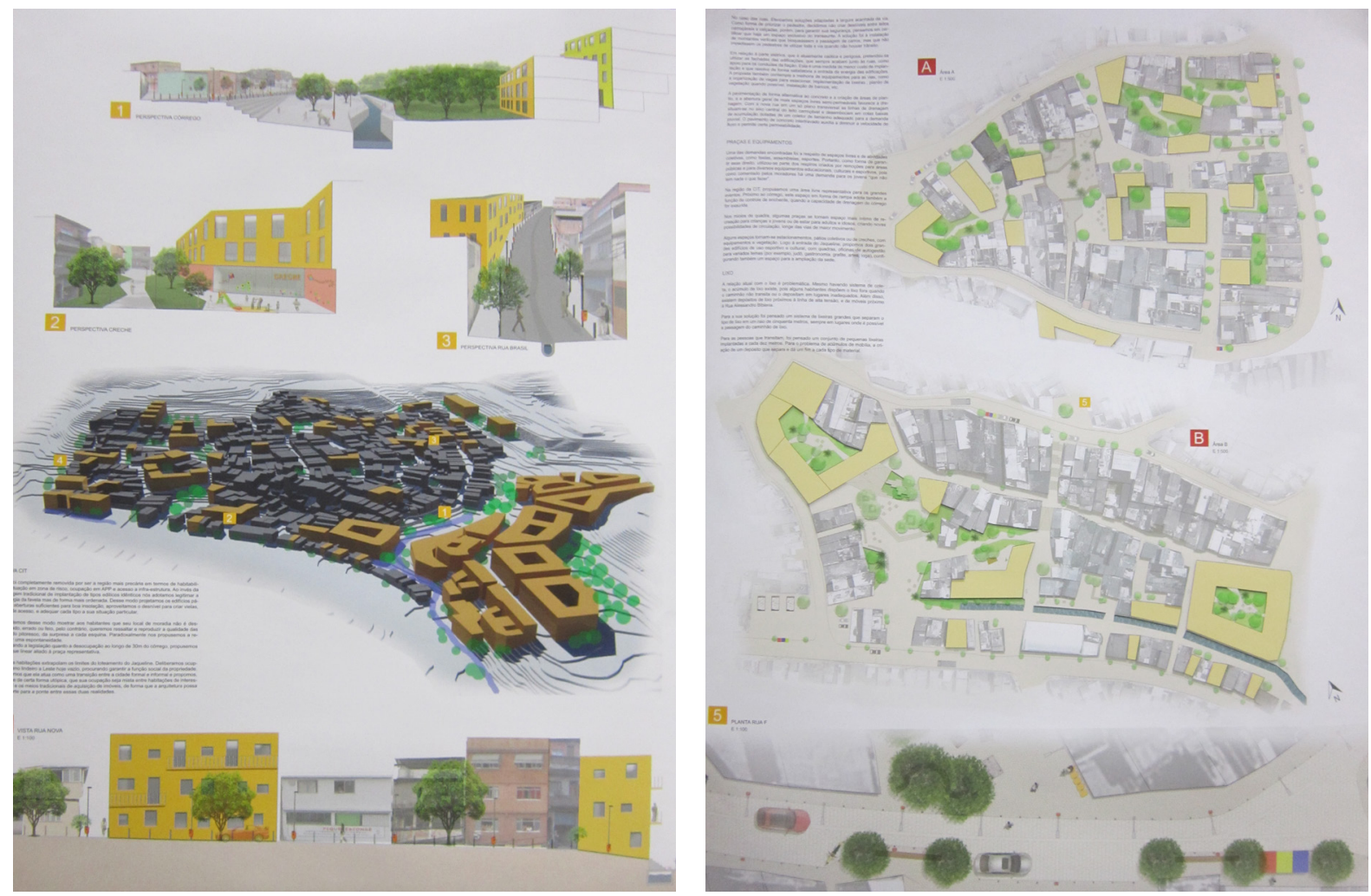

Imagem 37. Trabalho desenvolvido pelos alunos: Annkristin Meyhoff, Daniel Colaço, Larissa Candro, Luiza Gancho, Rodolfo Macedo, Yeni Li . Fonte: trabalho de alunos, disciplina "Desenho Urbano e projeto dos espaços da Cidade (AUP

bairros da classe média, como se o morador da ocupação de desenho espontâneo estivesse fatalmente associado a pobreza e precariedade, associados ao desenho tortuoso. É importante separar as questões ideológicas envolvidas no traçado espontâneo das favelas das questões estruturais ligadas a infraestrutura e situação de risco. Condições topográficas geológicas podem indicar a necessidade de remoção total das moradias, ou simplesmente a remoção temporária para implantação de infraestrutura e obras de contenção, com posterior reconstrução das casas.

Com referências ao vernacular europeu, empregado para legitimar uma estrutura urbana espontânea que não precisaria estar associada à pobreza e à precariedade, os alunos trouxeram um modelo de urbanização que consolida a estrutura existente, abrindo 'respiros" nos miolos de quadras e entre conjuntos edificados, para previsão de espaços 
públicos coletivos e condições de salubridade para núcleos extremamente adensados que perderam a possibilidade de insolação adequada. As novas unidades propostas seguem o mesmo princípio, de conjuntos de "condomínios" interligados por espaços livres públicos, com verticalização de baixo gabarito.

Podemos comparar a linguagem da favela às implantações vernaculares da Europa medieval, sem correr o risco de legitimar expressões derivadas da precariedade:

O reconhecimento do valor estético, arquitetônico e cultural dos assentamentos de favela é, certamente, um argumento favorável à política de consolidar as áreas ocupadas por favelas mediante obras de urbanização. Ao observar-se um núcleo habitacional, devemos procurar pelos sinais dos valores que a comunidade atribui ao ambiente construído (BUENO, 2000: 283).

Não faltam exemplos de cidades antigas em que desenhos não convencionais - como vielas, escadarias, edifícios sem recuos - são incorporados ao contexto urbano formal, proporcionando reações de surpresa e estranhamento, desejáveis em qualquer estrutura urbana que se pretenda que seja apropriada coletivamente. A incorporação de dados da natureza e da história é significativa nos exemplos bem sucedidos que conhecemos. Nas cidades históricas portuguesas e em nossas similares coloniais de Minas Gerais, a incorporação da topografia como partido é notória.

O cuidado necessário nesse tipo de comparação está relacionado à devida contextualização histórica e social de seu desenho: tecnologias existentes, meios de transporte, condição econômica dos moradores, condições materiais de produção. Laura Bueno chama atenção para o fato de que

quando a infra-estrutura [sic] urbana começou a ser desenvolvida, os moradores dessas cidades já tinham reconhecidos seus direitos como cidadãos proprietários ou usuários desse espaço, e que os investimentos foram feitos ao longo de séculos (BUENO, 2000: 289)

Esse dado poderia ser problematizado em relação às favelas brasileiras, que não possuem o grau de consolidação das cidades europeias e nem o longo desenvolvimento histórico que legitimou suas permanências no território, agregado ao valor histórico. Discute-se, no contexto das favelas, a necessidade de um processo de regularização global, que inclua a 
regularização urbanística e fundiária, e as dificuldades a serem enfrentadas em processos onde essas dimensões estejam apartadas. No caso das favelas brasileiras, a propriedade reconhecida, dentro de um universo de precariedade, pode comprometer a viabilidade financeira de obras de urbanização, já que as remoções necessárias seriam indenizadas de acordo com valores do mercado formal. A clareza em relação à diferença entre propriedade e segurança da posse é importante em contextos de precariedade, onde devemos garantir os direitos de moradores em relação à sua localização na cidade e permanência em seus contextos sociais. 0 título de propriedade pode ter papel contrário em relação ao reconhecimento desses direitos, quando servem de moeda de troca para famílias socialmente vulneráveis inseridas em um contexto social imediatista e extremamente consumista.

Se a "linguagem da favela é a linguagem da sobrevivência e da urgência, fatores de sua unidade e variedade", o entendimento da situação de aprisionamento em relação a uma dada realidade e a busca de processos de libertação e novas formas de apropriação dessa realidade são os primeiros passos em direção à invenção de novas paisagens. De acordo com a fala de uma das lideranças dos moradores do Jardim Jaqueline, discutir um projeto para a área é mais do que apresentar uma solução definitiva para a favela: é a apresentação de alternativas, da existência de possibilidades e, em um nível mais elevado, a colocação de uma nova perspectiva, de uma promessa de futuro. 


\section{CAPÍTULO 2. A CONTRIBUIÇÃO DA PESQUISA QUALITATIVA NO PROCESSO DE RECO- NHECIMENTO DAS DINÂMICAS LOCAIS}

\section{O CAMINHO DA PESQUISA QUALITATIVA: DESAFIOS E POTENCIALIDADES}

Com o entendimento de que os trabalhos técnicos realizados no Jardim Jaqueline para o processo de regularização fundiária fazem parte de métodos quantitativos de levantamentos e análise de resultados, que conformam procedimentos consensuais de planos de intervenção em favelas, nossa investigação utilizou como complemento ao processo de estudo do objeto métodos de trabalho provenientes da pesquisa qualitativa.

A abordagem qualitativa aqui empregada não possui a formatação existente nas áreas de atuação que se utilizam desse método, como a sociologia e a psicologia, visto que a abordagem qualitativa de investigação na paisagem está em processo de desenvolvimento por parte de estudiosos do tema, que entendem que os métodos quantitativos, considerados de forma isolada, não abarcam o dinamismo inerente ao que entendemos como paisagem. Estamos falando em um método consolidado em determinadas áreas de atuação, mas que necessita de adequações em pesquisas relacionadas ao contexto urbano, onde nos interessa as manifestações humanas na paisagem. Como a teorização a respeito do conceito de paisagem ainda se mostra pouco operativa em contextos extremamente formatados pelo pragmatismo como no caso das favelas, sentimos a necessidade de abordar a paisagem indiretamente, por meio de oficinas com grupos de moradores e entrevistas individuais com atores do entorno, com a finalidade de traçar um universo referencial e significativo, de acordo com diferentes percepções. A opção metodológica pela pesquisa qualitativa não significa o abandono do conceito de paisagem, que permeia todo nosso entendimento em relação ao objeto, mas uma abordagem capaz de incorporar as vozes dos atores envolvidos sem filtros conceituais que poderiam desviar o objetivo da pesquisa.

A leitura de referenciais teóricos sobre a pesquisa qualitativa nos mostra um importante aliado metodológico em nosso objetivo de captar as dimensões sensíveis do conhecimento, tão necessárias quando se trata do conceito de paisagem.

Diferentemente da pesquisa quantitativa, a qualitativa busca uma compreensão particular daquilo que estuda. Uma ideia mais geral sobre tal pesquisa é que ela não procura generalizações, princípios e leis. A generalização é abandonada e o foco de sua atenção é centralizado no específico, no peculiar, no individual, almejando sempre a compreensão e não a explicação dos fenômenos estudados (MARTINS, 2005: 23). 
E tal compreensão, de acordo com o autor citado, pode ser alcançada por meio da utilização de recursos e técnicas específicos, que tem como objetivo a busca das qualidades essenciais do fenômeno estudado. Buscamos em nossa pesquisa a dimensão sensível presente na paisagem e, para tanto, abandonamos o termo paisagem para tentar resgatá-lo no final do processo de compreensão de nosso universo de estudo. Acreditamos que, quando conseguimos aprofundar as dimensões sensiveis do conhecimento, caminhamos além do discurso e das representações vigentes, dando forma a subjetividades latentes, que podem vir a compor o imaginário coletivo local.

Trabalhar com o universo conceitual da paisagem com os moradores, dentro de nosso contexto cultural, equivaleria a condenar qualquer forma de paisagem expressa no local: se indagássemos a respeito da paisagem do Jardim Jaqueline, provavelmente teríamos a percepção socialmente aceita de que a paisagem não existe dentro de um contexto precário e que o ideal de paisagem somente seria possível com a destruição do existente, caindo no senso comum que norteia a construção da cidade formal.

Nesse sentido, a pesquisa qualitativa possibilita uma abertura em relação à abordagem do tema, onde o pesquisador pode alcançar seus objetivos a partir da inserção de temas correlatos, sendo que o conceito a ser investigado não precisa estar expresso em questionários fechados. As oficinas com grupos de moradores possibilitaram a exploração de temas de interesse do pesquisador por meio de dinâmicas, onde foram levantadas questões a respeito de suas memórias afetivas e demandas em relação ao lugar, que revelam a paisagem construída e as paisagens possíveis, de acordo com suas vivências e desejos.

A essa abordagem qualitativa, possível pelo contato direto com os moradores, foram incorporadas entrevistas individuais com atores do entorno, como forma de trazer contribuições de percepções externas à favela, com seus pontos de convergência e conflitos. Conversamos com uma moradora do condomínio de alto padrão vizinho à favela, um segurança do Shopping vizinho e uma moradora de um bairro horizontal do entorno.

Para a formatação das oficinas realizadas na favela, baseamo-nos nas leituras a respeito do processo de pesquisa-ação, de Michel Thiollent, e da pesquisa qualitativa em psicologia, de Joel Martins. Os trabalhos citados foram fundamentais para o delineamento da forma de abordagem em relação à pesquisa qualitativa, procurando o distanciamento em relação a abordagens clássicas de pesquisa em que questionários fechados são formatados de acordo com bases estatísticas, com resultados pouco abertos ao debate e questionamentos. Evitamos questões fechadas e perguntas longas ou complexas, abrindo a possibilidade de construção coletiva do processo de investigação. 
Apesar do partido adotado, não foi possível atender plenamente aos métodos propostos pela pesquisa-ação ou pela abordagem fenomenológica, pelos seguintes motivos: a pesquisa não foi desenvolvida por uma equipe, mas por uma única pesquisadora, que, apesar de contar com a colaboração preciosa de sua orientadora e de colegas de pesquisa, não conseguiria atingir o nível de desenvolvimento necessário à abordagem fenomenológica ou à proposta transformadora da pesquisa-ação; e a limitação de pesquisadores leva a outra necessidade dos métodos estudados, a interdisciplinaridade, necessária ao desenvolvimento de pesquisas de maior pretensão.

Apesar das limitações existentes, reconhecemos que a pesquisa qualitativa, principalmente quando se trata do fenômeno situado, é um meio preferencial de investigação de uma "natureza subordinada à maneira humana de pôr o problema", ou seja, a pesquisa de caráter fenomenológico tem o potencial de entender a realidade além das determinações objetivas que fazem parte de nossas representações formais, reconhecendo as transitividades e inter-relações subjetivas entre pesquisador e objeto. "O pesquisador só pode tomar como objeto de análise a experiência que tem dos acontecimentos que deseja estudar" (MARTINS, 2005: 75)

A forma de abordagem proposta remete a exemplos emblemáticos de pesquisas em territórios urbanos formatados por contextos sociais específicos, como os trabalhos de Carlos Nelson Ferreira dos Santos no Catumbi, em que esse abandona uma visão pragmática e determinista em relação ao estudo das relações sociais expressas no urbano, apostando nas contribuições da antropologia e da etnografia, questionando a visão dominante a respeito da construção da cidade voltada às médias e baixas rendas. O Arquiteto Antropólogo demonstrou de forma precisa as consequências, para os habitantes, de um projeto de remoção total de um bairro, comparando as redes de sociabilidade travadas no bairro em relação ao cotidiano de um conjunto habitacional construído nos moldes do "bom urbanismo moderno" da época.

Com as inúmeras referências disponiveis, ficamos com o desafio de imprimir a complexidade que o tema da pesquisa demanda, sabendo que não possuímos a formação necessária em relação às diversas áreas de conhecimento que compõem tal diversidade. Apesar do arquiteto não poder responder, sozinho, às questões levantadas pela antropologia, etnografia, ou psicologia, somos obrigados a pensar nessas interlocuções sempre que tratamos da vida de pessoas que habitam a paisagem e dela fazem parte, sem a pretensão de "orquestrar" tais relações, mas de forma a evitar intervenções equivocadas e, por vezes, irresponsáveis, tão comuns ao universo da arquitetura e do urbanismo. Nesse sentido, a pesquisa-ação nos ensina que: 
Para o entendimento dessa complexidade, as manifestações analisadas sempre serão consideradas dentro de seu contexto, ou seja, em relação ao "fenômeno situado". Apesar de não desenvolver a abordagem fenomenológica propriamente dita, o entendimento do fenômeno situado - em que o universo significativo estudado se relaciona aos objetos de estudo e ao universo referencial do pesquisador - estruturou o desenvolvimento das oficinas junto aos moradores. A escuta qualificada, dentro dos limites de formação da pesquisadora, buscou os significados de expressões e hábitos do cotidiano, colocados pelos moradores como naturais e definitivos, mas que podem indicar medos, necessidades, desejos e potencialidades dessa "realidade situada".

\section{PRIMEIRA OFICINA COM MORADORES DO JARDIM JAQUELINE - OFICINA DE APROXIMAÇÃO}

Iniciamos as oficinas programadas para a delimitação de nosso estudo empírico após um oportuno distanciamento temporal em relação aos trabalhos técnicos para regularização fundiária da área. Acreditávamos que o tempo decorrido facilitaria a inserção de novos temas de debate com os moradores, principalmente relativos ao estudo da paisagem. A adoção de questões abertas, buscando as memórias afetivas dos moradores em relação aos seus locais de moradia e a descoberta das potencialidades locais, passando pela investigação dos prováveis pontos positivos em meio às adversidades, procurou tirar partido das dinâmicas locais existentes.

Foram chamados os moradores constantes na lista voluntária de representantes, tirada do processo de regularização fundiária, pela facilidade de abordagem de uma amostragem que teoricamente estaria mais interessada nos assuntos relativos ao Jardim Jaqueline. Apesar de parcelar, o trabalho qualitativo com uma fração de moradores da comunidade previamente selecionada não foi aleatório, já que contou com a colaboração de moradores dispostos a participar das decisões relativas ao lugar. Podemos considerar que tal recorte configura-se como uma parcela significativa frente ao universo de moradores, mas não podemos chamar a amostra de grupo focal' ${ }^{1}$, devido à sua heterogeneidade, com moradores de ambos os sexos e diversas faixas etárias. Apesar da heterogeneidade, podemos caracterizar o grupo como predominantemente feminino, acima de 30 anos.

1 Os grupos focais utilizados na Pesquisa Qualitativa devem ser estrategicamente formatados para garantir os objetivos propostos em cada pesquisa. Se o objetivo, por exemplo, é vender um produto para o público feminino, o grupo focal será composto por mulheres de uma específica faixa etária e grupo social. Vale frisar aqui a dificuldade de se obter um grupo focal sem uma moeda de troca. No caso do Jardim Jaqueline, tentou-se realizar uma oficina com as crianças, por se tratar de um público com relações com os espaços livres que nos interessava, mas a baixa adesão inviabilizou a proposta. 


\subsection{A APRESENTAÇÃO DA PESQUISA E CONTRIBUIÇÕES INICIAIS DOS MORADORES}

Nessa aproximação inicial em relação ao tema e objetivos da pesquisa, compareceram 24 moradores e a pesquisadora, além de um colaborador que auxiliou na filmagem do evento. Na primeira oficina, a grande dificuldade foi a separação entre os personagens exercidos pela pesquisadora no local. Os moradores tiveram grande dificuldade em separar o trabalho da pesquisadora enquanto representante de uma universidade pública que realiza pesquisa com a comunidade e a arquiteta da instituição que promove os trabalhos de regularização fundiária.

Discorremos com muita calma sobre os objetivos da pesquisa, ressaltando suas implicações para os participantes e os ganhos em relação ao cotidiano dos moradores, que não estão expressos em um produto final ou em um ponto de chegada, mas na ativação de um processo participativo que tem como premissa o desenvolvimento progressivo das capacidades dos atores envolvidos. Tal processo inclui a capacidade dos moradores de participar ativamente das decisões que os afetam. A capacidade de participação também depende da assimilação de um universo referencial técnico, político e econômico, necessário ao desenvolvimento de propostas que possam melhorar a qualidade de vida dos moradores da favela.

A pesquisa foi colocada, em relação aos moradores, como um processo de troca de informações, no qual eles contribuiriam com dados empíricos fundamentais para o andamento da pesquisa e a pesquisadora contribuiria com o conhecimento técnico necessário para o processo de informação e formação dos moradores envolvidos no projeto de regularização da favela. Deve-se considerar que nesse momento os representantes presentes já tinham uma base de informações a respeito de seus locais de moradia, dada pelo trabalho realizado pela empresa que executou os trabalhos técnicos de regularização fundiária. Dentre os produtos previstos no edital de contratação da empresa estava incluso o trabalho social com a comunidade, com o objetivo de informá-los sobre seus direitos em relação à posse da área e instrumentalizá-los a respeito do processo de regularização fundiária e dos papéis dos diversos entes administrativos na resolução de seus problemas.

Durante grande parte da oficina, os moradores falaram sobre questões do processo de regularização fundiária do Jardim Jaqueline e questões pontuais, como locação de caçambas e asfalto. Após todas as contingências colocadas, conseguimos uma aproximação gradual em relação aos objetivos da pesquisa, sempre retomando o fato de que a pesquisadora não estava, naquele momento, representando a instituição que promovia o processo de regularização fundiária e sim uma universidade, com o objetivo de aproximação a um objeto de pesquisa diverso.

O peso das questões emergenciais, relacionadas às contingências cotidianas, se sobrepõe a qualquer tema relacionado à qualidade de vida, lazer ou urbanidade. Isso gerou muitas falas negativas em relação ao lugar, sugerindo que não 
tínhamos abertura para tratar daquela paisagem. Era inconcebível para aquelas pessoas falar em melhorias para seus locais de residência sem a garantia de que não seriam expulsas daquele lugar. Mais do que isso, mesmo tendo uma segurança relativa de que o Jardim Jaqueline dificilmente será "varrido do mapa", devido ao grau de consolidação alcançado e ao cadastro de moradores realizados para o processo de regularização fundiária, seus moradores buscam a garantia mais valiosa no mundo em que vivem, relacionada ao valor de troca de suas moradias. Mesmo quem não quer ficar no local espera a garantia de uma "escritura" como forma de inserção em um contexto social em que a propriedade proporciona a maior garantia de inserção urbana. Essa forte relação dos moradores com um universo de consumo que reúne diferentes classes sociais em torno dos mesmos ideais será discutida no próximo capítulo.

Dentro desse contexto, os moradores foram questionados sobre os pontos positivos de se morar no Jardim Jaqueline e as demandas locais, relativas às potencialidades existentes. Foi solicitado que relacionassem os pontos positivos a locais específicos, dentro ou fora do Jardim Jaqueline. Quando falamos em potencialidades, não estamos falando somente de hábitos positivos dos moradores em relação ao local, mas também de possibilidades que se revelam em meio às contingências. Uma potencialidade não é vista aqui como uma virtude, no sentido mais simples de uma característica positiva, mas como uma promessa de futuro.

Foram levantados como pontos positivos: a tranquilidade do lugar e as condições de acessibilidade; a proximidade a locais de consumo e facilidade de acessos e deslocamentos; a existência do Shopping e de muitos pontos comerciais de bairro; o posto de saúde; o acesso ao transporte público; a proximidade ao metrô. Como ponto positivo foi lembrado, por grande parte dos moradores, que a favela está localizada em área valorizada. Em relação a locais específicos, foi citado o Parque Raposo Tavares. Quando surgiu a referência do Parque, a oficina revelou o primeiro conflito relativo à memória afetiva dos moradores. Existe uma relação afetiva contraditória em relação ao Parque, principalmente por parte dos moradores mais velhos, que reconhecem o reconhecem como referencial de lazer, mas que possuem histórias de vida relacionadas ao local quando ele era um depósito de lixo. Foi lembrado que o Parque já foi eleito como o pior da cidade e que hoje, após reforma, se tornou uma referência de lazer, principalmente para as crianças². A referência de lazer divide espaço com a referência do lixo e da extrema necessidade, que faz parte do imaginário dos moradores mais velhos, que se lembram da época em que o Parque era um lixão, o lugar onde catavam restos de lixo para o seu sustento e de sua família ${ }^{3}$.

As imagens da necessidade material e da contingência marcam profundamente o imaginário dos moradores, que fazem questão de lembrar que vivem no Jardim Jaqueline porque não possuem condições de adquirir uma moradia em áreas
2 Estudo aponta Raposo Tavares como pior parque da cidade. Disponível em <http://www.piniweb.com.br/ construcao/carreira-exercicio-profissional-entidades/estudo-do-sinaenco-avalia-conservacao-dos-parques-paulistanos-e-aponta-123833-1.asp>. Acesso em: 24 Jul. 2013.

30 filme experimental "Restos", de João Batista de Andrade, mostra um pouco da realidade desses moradores na época, captando "em imagens aterrorizantes, 0 cotidiano de um grupo de miseráveis que vive da cata do lixo num aterro sanitário da Rodovia Raposo Tavares. Mulheres, crianças, velhos, desempregados etc., que disputam latas, papéis e restos de comida despejados no local. Censurado pelas autoridades, não pode ser exibido na Jornada Brasileira de Curta-Metragem de 1975". Disponivel em: <http://www. videotecas.armazemmemoria.com.br/ Video. aspx?videoteca $=\mathrm{NQ}==\& \mathrm{v}=\mathrm{Nz}=>$. Acesso em: 29 Jul. 2013.

A existência dessa referência nos permite associar o processo de ocupação da favela ao lixão vizinho. Os primeiros moradores estariam associados à atividade produtiva das olarias do entorno à criação de porcos e ao lixão vizinho. Disponivel em: <http://www.curtadoc.tv/ curta/index. . hp??id=462>. Acesso em: 24 Jul. 2013. 
regulares e que a questão que mais os aflige é a insegurança a respeito da permanência no local. O principal objetivo a ser alcançado no momento é a conquista da segurança de suas posses. Apesar do histórico de necessidades apresentadas, grande parte dos moradores aponta como prioridade a regularização fundiária da favela. Essa prioridade apresentada pode estar relacionada ao papel da pesquisadora junto à Defensoria Pública, fato que pode explicar a prioridade da regularização em detrimento da solução da precariedade encontrada na favela no que diz respeito à rede de esgoto, às áreas nas margens dos córregos e às áreas que necessitam de intervenção urgente do poder público.

Sobre o tema da participação, lembramos que o local necessita de um projeto de urbanização, que inevitavelmente será promovido pelo município, e que deverá contar com a disposição dos presentes para participar do Plano de Urbanização da ZEIS do Jardim Jaqueline. A pesquisadora lembra que um projeto urbanístico tem como objetivo unir todas as questões pontuais comumente citadas - como esgoto, luz, asfalto e lixo - em torno de uma proposta, que deve contar com a participação dos moradores, não somente de forma fragmentada, mas em relação a um projeto de cidade, onde se inserem suas futuras moradias. Como eles visualizam esse projeto? E se o poder público colocar a questão das remoções necessárias, quem estaria disposto a sair do Jardim Jaqueline para outro local? Como negociar a permanência?

Acreditávamos que a questão colocada, que trouxe a perspectiva da saída dos moradores de seus locais de residência, poderia trazer à tona as relações socialmente construídas em relação ao lugar. Em um primeiro momento, os moradores retomaram as questões práticas que justificariam a vontade de permanência dos moradores, como acessibilidade e vantagens locacionais, mas as falas subsequentes apontaram as relações de afetividade localmente sedimentadas. 0 fato de terem construído suas casas é colocado como fator de defesa da permanência. A fala "Temos casa, família, tudo aqui" demostra uma relação de pertencimento que extrapola a simples relação prática de serviços e acessibilidade inicialmente colocada. As relações mais estreitas com o lugar são mais facilmente percebidas nos moradores mais velhos, que, apesar das histórias de sofrimentos relatadas, valorizam as conquistas alcançadas e sentem-se orgulhosos de pertencer a uma história de lutas. Os moradores mais novos expressam uma relação mais prática com a paisagem local. A natureza dessa relação será melhor problematizada no próximo capítulo.

Nessa primeira oficina devemos ressaltar a presença de uma das lideranças locais, que permaneceu calada na maior parte do tempo, apesar de sua eloquência e capacidade de convencimento frente aos moradores da favela. Quando foi questionada individualmente a respeito das questões discutidas coletivamente, discorreu sobre uma representação do processo de ocupação da favela que costuma relatar em conversas informais, que é o processo de substituição dos barra-
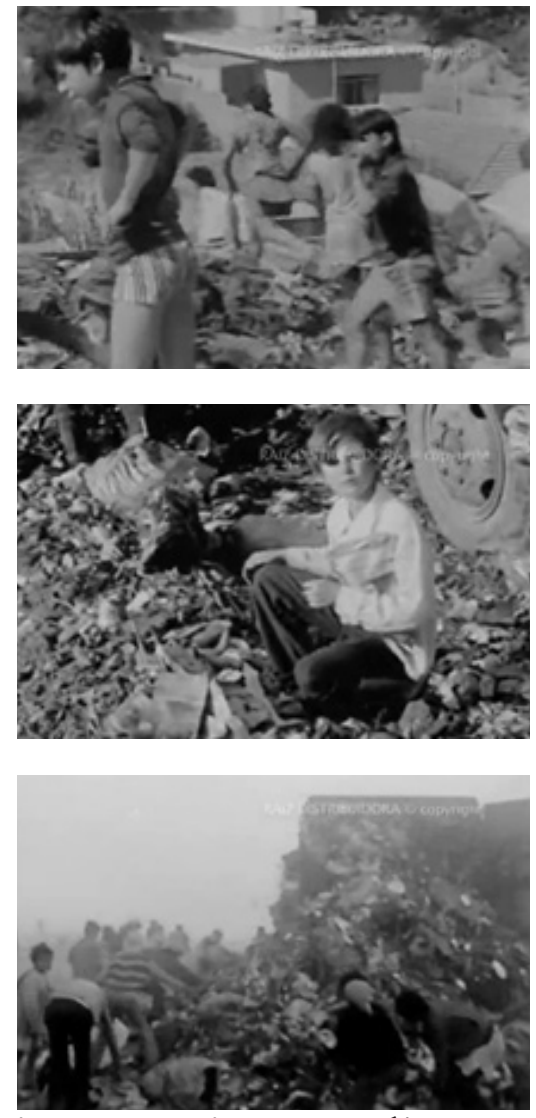

Imagens 1, 2, 3. Imagens extraídas do filme "Restos", de João Batista de Andrade. Cf. nota de rodapé $n^{\circ} 3$ deste capítulo. 
cos de madeira por alvenaria. A liderança chegou no Jardim Jaqueline em 1990, proveniente da favela do Jaguaré, quando ainda existiam muitos "barracos" e a população começava a substituir as estruturas de madeira por alvenaria, utilizando uma técnica em que a alvenaria era levantada por dentro da moradia, e quando a madeira era retirada, "a casa estava pronta". A liderança acredita que, desde a substituição dos barracos de madeira, o Jardim Jaqueline passou a assumir um caráter de bairro, com a predominância das construções em alvenaria. Ela se diverte lembrando-se do processo de construção de sua casa, utilizando-se do "tradicional" método de substituição da madeira pela alvenaria, ocasião em que os moradores vizinhos diziam: "Vai cair, vai cair". E a cada novo tijolo colocado, o mesmo comentário.

E assim foi com a maioria das casas, até a atual configuração, considerada, pelos moradores, semelhante à de um bairro. Esse relato foi presenciado pela pesquisadora em outras ocasiões, inclusive com a explicação da técnica empregada para edificar sobre o córrego. Nesse relato, a liderança lembra que morava "para dentro da rua" quando adquiriu um carro e necessitou de uma vaga para estacioná-lo. De acordo com a nova necessidade, a família se mudou para a beira do córrego, onde, com o tempo construiu uma laje sobre ele e conquistou uma frente de rua. A pesquisadora aprendeu na ocasião, com os relatos da liderança, qual era a estrutura de concreto necessária para se "vencer" o córrego 4 .

O relato da liderança desperta as lembranças sobre o processo de ocupação da favela, que surpreende os moradores pela velocidade das mudanças e conquistas alcançadas, de acordo com a visão dos presentes. Surgem lembranças relacionadas a antigas estruturas existentes: um chiqueiro, que existia logo na entrada da favela; poços existentes nos quintais para abastecimento de água; e a nascente do córrego localizada na área onde hoje está implantado o Shopping. A mina d'água é lembrada, não como representante de uma natureza degradada ou cenário idílico, mas como meio de subsistência, empregada para abastecimento e necessidades básicas. Todas as lembranças relatadas vieram relacionadas à ideia de progresso atual em relação a uma situação anterior já superada. A lembrança da nascente e curso do córrego está atrelada a uma realidade de extrema necessidade, que foi superada e sobre a qual não paira nenhuma memória positiva.

Na mesma linha de valores associados ao local, a maioria dos moradores presentes vê no tamponamento da nascente um símbolo positivo, como se a época em que ela existia estivesse associada a um contexto de restrições ao qual os moradores não querem retornar. Os símbolos do progresso, tais como redes de infraestrutura e tamponamentos, considerados dentro de uma relação de necessidade e meio, são bem-vindos. O antigo estado dos cursos d'água e suas nascentes são associados à precariedade e ao atraso.

Essa relação extremamente negativa com os córregos, proveniente do contexto referencial dos moradores, se choca
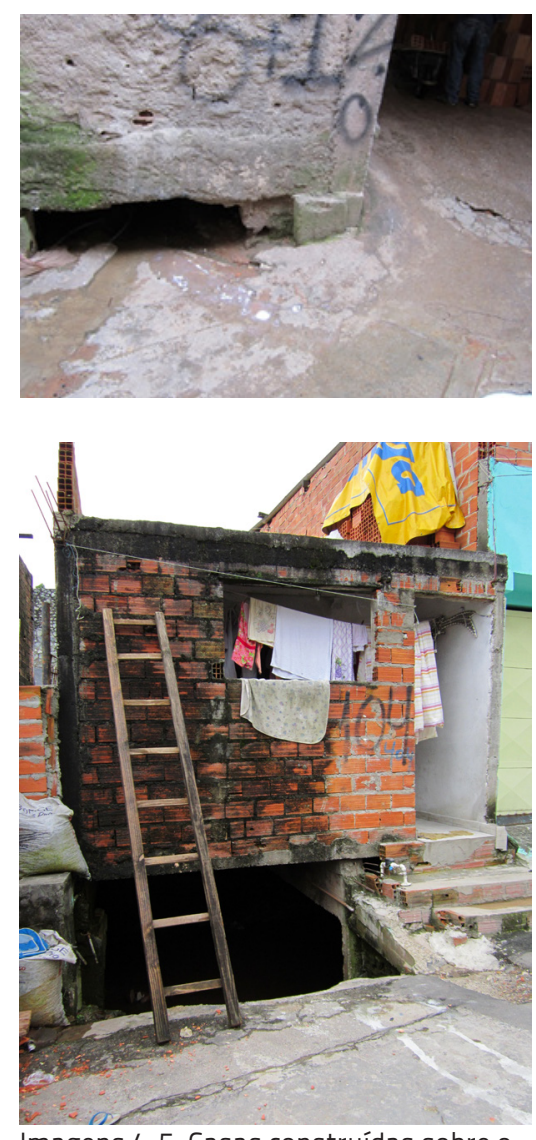
Imagens 4, 5. Casas construídas sobre o córrego

4 Tais agenciamentos da vida prática são comuns aos moradores de favela, que compram, trocam e reformam suas moradias de acordo com a conveniência de cada momento. A liderança em questão trocou seu barraco da favela do Jaguaré por um 
radicalmente com o senso comum proveniente do contexto referencial da pesquisadora, que tenta evocar referências sensíveis em relação aos cursos d'água, no momento em que os moradores situam o tema em seu devido lugar dentro daquela discussão: a frase "Tinha que tomar banho ali, não tinha banheiro!" coloca um ponto final no debate.

Uma voz divergente destoou em relação ao consenso criado quando, dizendo que achava que a nascente não deveria ter sido tamponada, lembrou que "A mina é a história desse pedaço [...]. Aquela mina deveria permanecer, para que todos soubessem como era quando a gente chegou aqui". Apesar da fala não procurar pontos positivos no fato, demonstra uma preocupação com sua memória e dos moradores, como forma de valorização de uma trajetória que deve ser lembrada, em uma época em que "Os moradores precisavam subir a Rua Sebastião Gonçalves descalços, levando o sapato na mão [...]", já que era tudo enlameado. É recorrente entre os moradores mais velhos o relato das dificuldades passadas como forma de reconhecimento da trajetória e das vitórias alcançadas, seja por parte dos moradores mais novos ou do poder público. Apesar das frutíferas discussões sobre as nascentes e cursos d'água, a maioria dos moradores presentes não se recordava das nascentes existentes onde hoje se localiza o estacionamento do Shopping.

Sobre a questão da tranquilidade e segurança, apontadas como pontos positivos, chama atenção o comentário de que "mesmo sendo comunidade", os moradores se consideram muito seguros em seus locais de residência, mesmo considerando questões relativas ao poder interno vigente, que permeiam suas vidas. Mesmo em relação a essa realidade, os moradores se consideram respeitados dentro da favela. Essa visão é partilhada por todos os presentes. Interessante notar que, apesar do uso da terminologia "comunidade" apontar para uma necessidade de distanciamento simbólico dos moradores em relação a uma

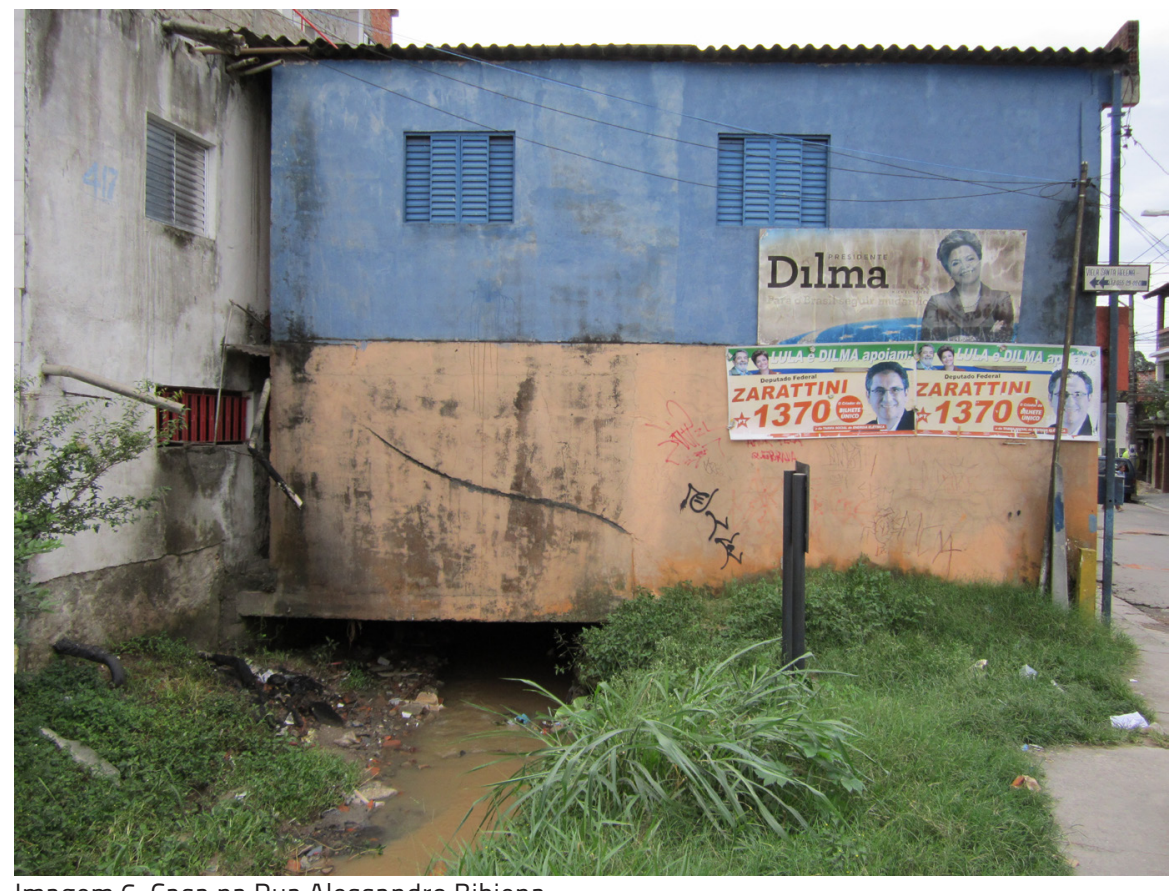

Imagem 6. Casa na Rua Alessandro Bibiena

equivalente no Jardim Jaqueline, devido a desentendimentos ocorridos no antigo local de moradia. No Jardim Jaqueline, a primeira moradia, localizada 'mais para dentro" da favela, também foi permutada, e a liderança se instalou em um 'terreno" sobre o córrego, para adquirir uma 'frente de rua" e conseguir estacionar seu carro. Da mesma forma, alguns moradores presentes nas oficinas relataram seus deslocamentos pela favela. 
condição estigmatizada de inserção social, o termo acaba se tornando sinônimo de favela no senso comum dos próprios moradores. Nesse ponto e em outras colocações dos moradores, podemos reconhecer a existência de "muros imaginários", que separam a favela do entorno imediato.

Adentrando no universo das carências e potencialidades, as mães presentes lembram que existem poucos locais de "lazer para as crianças" no entorno próximo, já que os locais de lazer existentes, como o Parque, seriam distantes para as crianças pequenas. Relatos de mães indicam que, pela falta de locais de lazer próximos, seus filhos ficam o dia todo vendo televisão. Espaços existentes, como o balneário, não teriam vagas suficientes. Os moradores lembram da existência de um terreno vazio na Rua Sebastião Gonçalves, que é apropriado como campo de futebol e que poderia ser reabilitado para o lazer das crianças. A Associação de Moradores tinha intenção de comprar o terreno, com ajuda da Liga das Senhoras Católicas 5 , para fazer uma creche, mas o proprietário não quis vender porque pretendia construir um posto de combustível no local. O mesmo local também já foi utilizado como velório de moradores do Jardim Jaqueline.

Questões de acessibilidade foram lembradas por moradores com parentes com dificuldade de locomoção, que apontaram a total ausência de acessibilidade no Jardim Jaqueline e em relação aos equipamentos do entorno. A piscina do balneário, por exemplo, não pode ser frequentada por deficientes físicos.

Quando questionados a respeito dos "espaços livres", os moradores associaram ao lixo, desorganização e desrespeito dos próprios moradores em relação à utilização dos espaços coletivos. Aos poucos essa visão comportamental foi contraposta às carências físicas, como ausência de calçadas, de limites entre o que seria o espaço público e os espaços apropriados pelas construções, e até à ausência de grades, revelando o imaginário de enclausuramento importado de modelos empregados pelas classes médias. A pesquisadora relatou aos presentes na oficina dados a respeito de uma área verde recentemente disponibilizada ao lado do Shopping.

A pesquisa fundiária realizada no local e no entorno revelou a existência de reservas de áreas verdes resultantes dos loteamentos regulares vizinhos que nunca foram utilizados efetivamente pelo poder público e foram, em grande parte, ocupadas pela favela. Parte de uma dessas áreas foi ocupada pelo Shopping. Recentemente a administração do Shopping deslocou sua cerca de divisão, revelando a existência de uma área verde pública, onde foram plantadas árvores, sem qualquer equipamento de lazer. Os moradores se mostraram pouco informados a respeito da área: "Não seria da prefeitura?". Apesar de acharem que o local poderia ser utilizado para suprir demandas da comunidade, em um primeiro momento não souberam dizer o que fazer.
5 A Liga das Senhoras Católicas, ou Liga Solidária, é uma organização beneficente que realiza projetos sociais em comunidades de baixa renda. Disponivel em: $<w w w$.ligasolidaria.org.br . Acesso em: 30 Jul. 2013. 

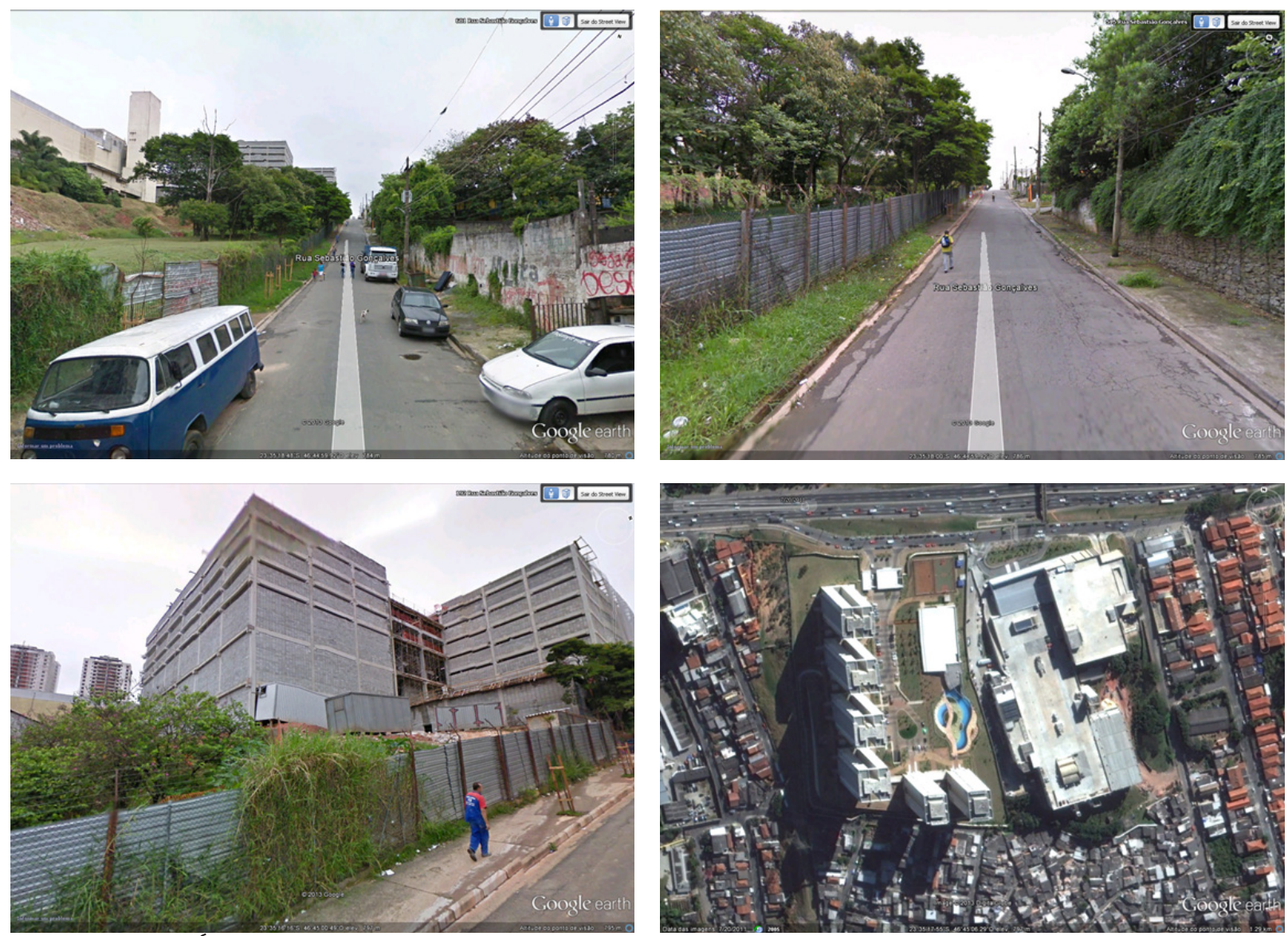

magens 7, 8, 9, 10. Área verde ocupada pelo Shopping, em vistas da Rua Sebastião Gonçalves. Fonte: Google Earth, 2010

Os presentes na oficina foram questionados a respeito da necessidade de participação no processo de criação daquela área verde, onde parte das demandas que eles estavam expondo naquele momento poderiam ter sido atendidas. Em um contexto em que os moradores questionam a ausência de espaços de recreação para as crianças, ausência de calçadas e de qualquer acessibilidade para portadores de necessidades especiais, uma área verde vizinha à favela não deveria pensar nas demandas existentes? E não seriam os potenciais usuários do local os consultores mais adequados para expor tais demandas? 
Os moradores mal sabiam que se tratava de área pública anteriormente ocupada pelo Shopping, muito menos o contexto de ocupação das reservas de áreas verdes do entorno. Sabemos que o Shopping ocupa, além da reserva de área verde, uma pequena fração da matrícula onde se encontra o Jardim Jaqueline. Na época em que o Shopping ampliou seu estacionamento sobre as nascentes, em 2011, o muro que se encontrava no alinhamento da calçada foi deslocado para dentro do terreno, devolvendo um espaço público que estava sendo indevidamente apropriado pelo centro de compras. 0 muro que separa o Shopping do Jardim Jaqueline não foi deslocado, ocupando ainda parte da matrícula onde se situa a favela.

A pesquisadora lembrou que, assim como ocorreu com a área verde citada, um projeto para a favela pode ser construído à revelia dos interesses dos moradores, que poderão ser reduzidos a meros expectadores de suas vidas. Foi colocado que, com esse exercício que estava sendo realizado, de identificação de memórias afetivas, deficiências e potencialidades em relação ao local e identificação de demandas do Jardim Jaqueline, os moradores estavam adquirindo instrumentos para o futuro debate sobre as transformações necessárias: a experiência dos moradores deve se aliar ao conhecimento técnico e não ser subjugado por ele.

\subsection{INFORMES INTERNOS}

Após cerca de uma hora de debates sobre a pesquisa em andamento, os moradores aproveitaram o tempo restante para discussão de questões relativas ao cotidiano da favela. Essa parte da reunião foi conduzida pela liderança presente, que iniciou os informes anunciando o projeto da Eletropaulo para a favela e alertando: "Nós, que somos comunidade, temos que ficar 'muito ligeiro'" se referindo à entrada da Eletropaulo na comunidade, por meio de um projeto de regularização da energia elétrica, que inclui doação de geladeiras e lâmpadas econômicas ${ }^{6}$

Chama atenção a avaliação da liderança a respeito da regularização do fornecimento de energia elétrica na favela:

Eles vão colocar um 'reloginho' em cada casa, nem que seja um barraco. E esses postinhos de rua, esses postinhos que ficam na casa de vocês, não vai ter mais. Gato, quem tiver um gatinho, não vai ter mais gatinho. E depois que eles entrarem, não tem mais gatinho não. Tem isso aqui, ó [apontando para o bolso], no seu bolso, entendeu? E depois você vai pagar o que você gastar. E se você não pagar, o seu nome vai para o SPC. Você vai ficar com nome sujo, não pode mais comprar nada. Seu nome fica bloqueado, se você não pagar sua conta. Vocês vão ser reféns da Eletropaulo.
60 Programa da AES Eletropaulo, "Programa Transformação de Consumidores em Clientes", tem como objetivo a regularização de 75 mil ligações em comunidades espalhadas por 24 municípios em 2013 e 175 mil ligações até 2016. Disponivel em: <www.aeseletropaulo. com.br>. Acesso em: 29 Jul. 2013. 
A liderança ressaltou que iria consultar o "seu Deputado" para saber se a comunidade iria aceitar os termos do projeto da Eletropaulo. Antes de implementar qualquer projeto na favela, representantes da Eletropaulo consultaram a Associação de Moradores e aguardaram a posição da liderança, que autorizou o projeto um mês após a realização da oficina. Os informes dados pela liderança vieram acompanhados de um clima de otimismo, decorrente da eleição de um novo prefeito e vereadores, apoiados pela comunidade. No momento, os moradores presentes acreditam que a solução para os seus problemas está mais próxima. A liderança se recorda da diferença de tratamento recebida nas gestões anteriores, de prefeita do partido aliado e outro da oposição, onde as moradias removidas eram substituídas por outro local de moradia, no primeiro caso, ou pelo chamado "cheque despejo", no segundo?.

Outra questão relatada pelos presentes está relacionada ao "equilíbrio instável" mantido pelas lideranças e população da favela com o poder interno vigente. Houve um encontro entre os comerciantes, associação de moradores e responsáveis pelo chamado "poder paralelo" dentro da favela para tratar da onda de roubos que ocorreram no período, que coincidiu com a época em que a Polícia Militar ocupou favelas de São Paulo ${ }^{8}$. A articulação foi necessária após episódios de assaltos ao caminhão das Casas Bahia e carteiros dos Correios, que desestabilizaram as relações de confiança de uma comunidade caracterizada pela tranquilidade interna à favela, fato sempre exaltado por seus moradores.

Depois da tal reunião, o "poder paralelo" recuperou a "ordem" dentro da comunidade, visto que a instabilidade interna não é conveniente para as atividades exercidas no local. Chama atenção, nos relatos sobre o tráfico, as denominações dadas pelos moradores à sua hierarquia interna, onde os subordinados, ou a "molecada", não se confundem com os dirigentes, ou a "disciplina". Apesar do poder público, representado pela polícia, ter estado mais presente na época, sua

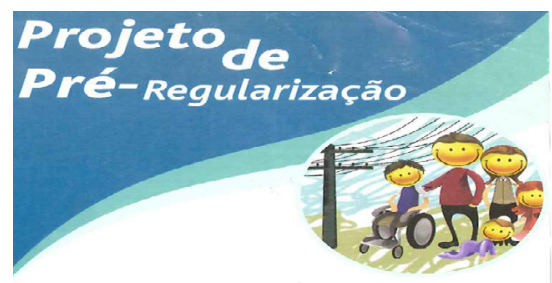

INFORMAMOS QUE A AES ELETROPAULO, REPRESENTADA PELA EMPRESA
MGD ENGENHARIA INICARA O PROJETO

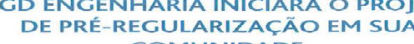
PARA MAIORES INFORMAÇŌES COMPAREÇA NA "PALESTRA" QUE ACONTECERÁ DIA 27/04/2013 HORARIO: 11 HORAS LOCAL: RUA PEDRO BEZERRA, 1244 (SEDE COMUNITARIA) CONTAMOS COM SUA PRESENCCA

屯. AES Eletropaulo PEE $\quad \Leftrightarrow \Rightarrow$ ANEEI

COMA REGULARIZAČÃO, A COMUNIDAD CLIENTE EXERCER SEU PAPEL DE

BENEFÍCIOS DA REGULARIZAÇÃo: (E) Valorizaçăo da Comunidade

Comprovante de Endereso (abertura de crediaribs) Minimizar Riscos de Incendio Evitar queimaduras ou morte por Choque Elétrico (i) Ser ressarcido (indenizado) por produtos queim (-) Ser informado sobre a interrupção programada do (1) serinso A AES ELETROPAULO TRANSFORMANDO CONSUMIDORES EM CLIENTES

AES Eletropaulo
Na Comunidade

Imagem 11. Folder do Projeto de Pré-Regularização da Eletropaulo

7 Em 2012, a equipe do grupo de pesquisa "Observatório de Remoções", proveniente de laboratórios de pesquisa da FAU-USP, elaborou importante mapeamento das dinâmicas de deslocamento da população de baixa renda em São Paulo. Seus dados iniciais, levantados em 2012,

evidenciam a dimensão da questão das remoções causadas por projetos urbanos e processo de valorização imobiliária. Disponivel em: <www.observatorioderemocoes.blogspot.com.br>. Acesso em: 29 Jul. 2013.

8 A chamada "Operação Saturação", ocorrida entre outubro e novembro de 2012 fez parte da atuação da Polícia Militar em favelas de São Paulo, com objetivo de capturar criminosos e sufocar o tráfico de drogas. 
presença pouco alterava a sensação de insegurança dos moradores. De acordo com avaliação conjunta, em situações de conflito relacionadas à segurança, a população deve articular suas reivindicações direcionados não ao poder público, mas ao poder interno, que teria maior interesse em relação à estabilidade e segurança da comunidade.

Apesar de percebermos o extremo controle exercido pelo "poder paralelo" junto à favela, fica claro o papel conciliador das lideranças comunitárias como dado estratégico para manutenção da estabilidade interna do local. Em detrimento da rotatividade da estrutura do poder interno vigente, as personalidades que representam a associação de moradores exercem seu papel de liderança há, pelo menos, 12 anos, fato que contribui para a consolidação de uma relação de confiança com os moradores e para a manutenção do diálogo com os órgãos públicos. As relações existentes entre o irregular, o ilegal e o ilícito na configuração das relações sociais expressas no espaço são importantes para o entendimento das dinâmicas da paisagem local, merecendo maior desenvolvimento.

\subsection{PRINCIPAIS PONTOS DE REFLEXÃO}

O principal ponto a ser questionado em relação ao formato proposto de oficinas para o desenvolvimento do processo de investigação qualitativa diz respeito à relação da pesquisadora com os moradores. 0 papel desempenhado pela pesquisadora na instituição promotora do processo de regularização fundiária na favela não pôde ser separado do papel exercido como pesquisadora na ocasião da oficina.

Os moradores não deixaram de ver na pesquisadora a figura da arquiteta da Defensoria Pública. Esse fato pode ter gerado condicionantes nas falas dos moradores, como no caso do apontamento de prioridades, que constantemente vieram acompanhadas do processo de regularização fundiária da área.

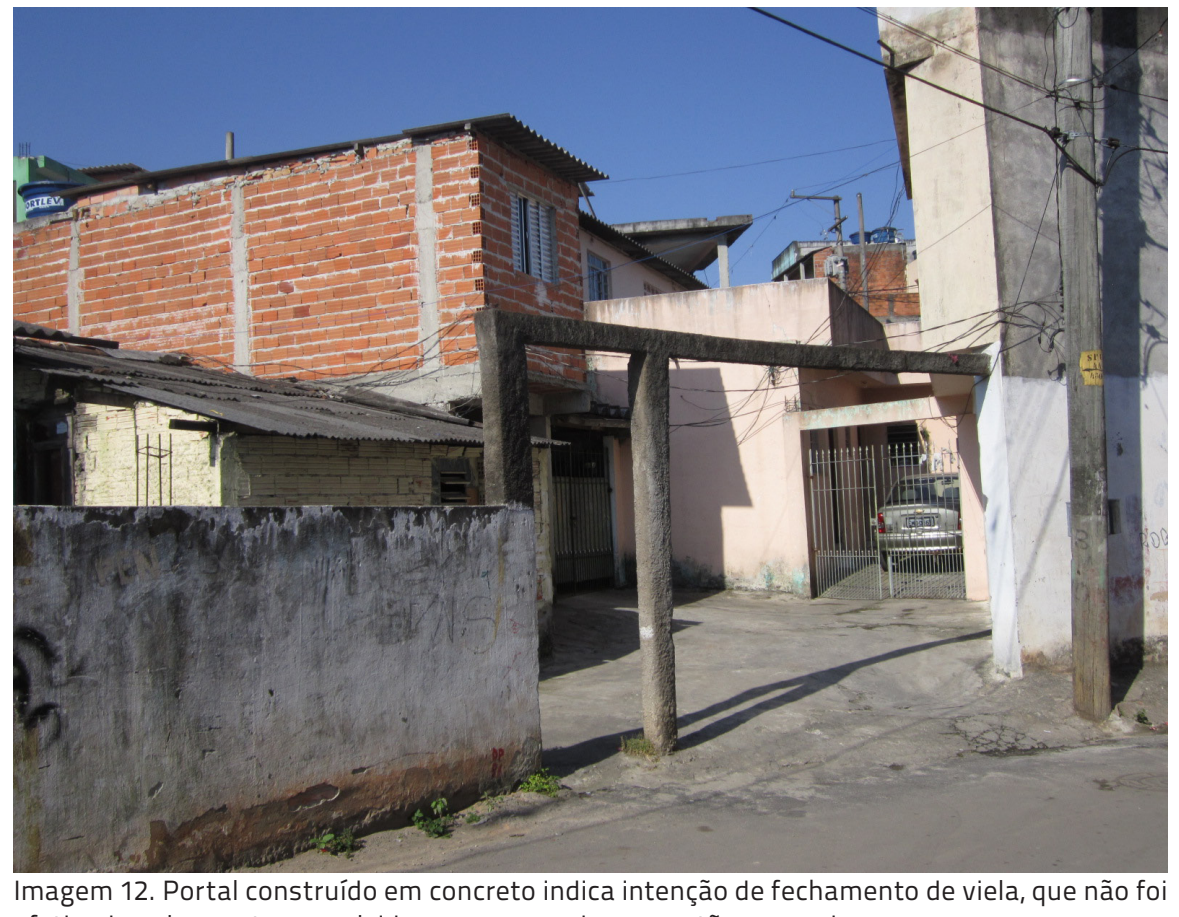
Imagem 12. Portal construído em concreto indica intenção de fecham
efetivada pelos custos envolvidos na compra de um portão ou grade 
Podemos relativizar o peso referencial exercido pelo papel da pesquisadora se considerarmos que o ideal de regularização fundiária está fortemente arraigado no imaginário dos moradores a partir dos trabalhos técnicos executados na comunidade durante o período de um ano. De acordo com essa avaliação, um pesquisador com referencial "neutro" em relação à comunidade também chegaria às mesmas conclusões em relação às prioridades elencadas. Além da parcialidade apontada, dos moradores em relação à pesquisadora, o inverso também deve ser ressaltado.

A pesquisadora realizou a oficina após contato de cerca de dois anos com a comunidade, o que trouxe um universo referencial substancial ao ambiente de pesquisa. Se o personagem assumido pela "arquiteta da Defensoria" se sobrepôs ao da pesquisadora, esse fato deve ser considerado como um facilitador em relação à inserção na favela. Não seria possível afirmar se o personagem "pesquisadora" teria a mesma inserção em meio a moradores e lideranças.

A questão da imparcialidade e neutralidade aparece bem resolvida no universo da pesquisa qualitativa:

[...] não existirá neutralidade do pesquisador em relação à pesquisa - forma de descortinar o mundo -, pois ele atribui significados, seleciona o que do mundo quer conhecer, interage com o conhecido e se dispõe a comunicá-lo. Também não haverá 'conclusões', mas uma 'construção de resultados', posto que compreensões, não sendo encarceráveis, nunca serão definitivas (GARNICA, 1997: 2).

Está claro que não se espera neutralidade em um ambiente repleto de referenciais, subjetividades e conflitos entre grupo e pesquisador e entre integrantes do grupo. Considerando-se que o grupo não é homogêneo, não se constituindo em um grupo focal, como demanda a pesquisa qualitativa, outro conjunto de condicionantes se coloca no universo da pesquisa. A construção de significados esperada deve considerar que a comunicação entre moradores e pesquisador não revela as reais subjetividades em relação ao universo investigado, mas intermediações entre os diálogos processados dos moradores, dentro de um recorte dos significados que eles desejam transmitir, e o universo referencial do pesquisador, contaminado por hipóteses de pesquisa e premissas conceituais.

Essa contaminação por parte do pesquisador é nítida quando a formulação das questões vem carregada de hipóteses que não são confirmadas. Como no exemplo da percepção em relação aos cursos d'água, que, na visão do pesquisador, poderia fazer parte das memórias afetivas dos moradores mais velhos, mas se revelou como uma lembrança negativa, associada a um contexto de extremas necessidades. Podemos considerar que o universo subjetivo dos moradores não foi 
suficientemente revelado no contexto da oficina ou que as representações que surgiram, carregadas de contingências e necessidades revelam um cotidiano embrutecedor, capaz de eliminar os referenciais pertencentes ao universo do sensível e do subjetivo.

Os resultados obtidos não podem ser considerados como conclusões definitivas a respeito do universo referencial dos moradores, mas como um processo de intermediação entre as informações que o pesquisador espera obter e as informações que os moradores desejam transmitir. Como exemplo, podemos citar a postura da liderança presente na oficina, personagem extremamente comunicativo que preferiu adotar uma atitude de reserva e observação. Na avaliação da pesquisadora, a liderança se reservou ao seu papel enquanto liderança, eloquente no momento dos informes, já previamente processados, e reservada no momento dos debates, que envolviam confrontos onde não havia uma posição assumida da Associação, como na questão da área verde apropriada pelo Shopping. A pesquisadora sabia que todas as questões associadas ao Shopping eram de total domínio da Associação, que estabelece costuras "diplomáticas" em relação ao centro de compras vizinho, mas adota postura de reserva em relação a essas costuras, que são de ordem política interna.

Caminhando em direção ao "descortinamento" das estruturas postas, previamente colocadas como definitivas, podemos problematizar algumas questões vocalizadas pelos moradores. Inicialmente as falas revelam que os moradores querem colocar todas as questões que convencionaram serem prioritárias em relação aos seus cotidianos: desde infraestruturas de água, esgoto, luz, coleta de lixo e asfaltamento de ruas até a grande demanda da regularização fundiária.

Questionados sobre outras dimensões de suas necessidades, não incluídas em um primeiro momento, lembram que: a grande questão não é a qualidade do asfalto, mas a ausência de uma calçada, que inviabiliza a circulação de pedestres; que o problema do lixo também está associado à precariedade dos espaços livres; e que o universo de carências apontadas também está relacionado a um entorno imediato pouco explorado pelos moradores, como a área verde do Shopping.

Os discursos também revelam valores profundamente arraigados no imaginário de todas as classes sociais, como o ideal do fechamento dos espaços, tanto públicos como privados, quando os moradores citam a ausência de grades como fator de acúmulo de lixo. Podemos notar, em toda a favela, grande número de espaços fechados, configurando verdadeiros "condomínios fechados", com muros e grades que delimitam espaços que podem ser acessados somente por moradores de determinado conjunto de casas.

Esse processo de questionamento das camadas de referenciais e entendimentos da realidade implícitos nas falas dos moradores também pode ser aplicado à pesquisadora, que pode descobrir diversos graus de "limites de classe" quando 
se surpreende com questões colocadas pela pesquisa que não fazem parte do universo referencial dos moradores.

Em relação à primeira oficina podemos afirmar que as mulheres trazem, predominantemente, preocupações relativas ao bem-estar de seus filhos e questões de deslocamento, como segurança e possibilidade de deslocamento das crianças mais novas. Tal preocupação se justifica quando presenciamos crianças de cinco, seis ou sete anos frequentando o Parque sozinhas, fato que causou estranhamento por parte da pesquisadora, que se enquadra em um universo social onde as crianças não frequentam parques desacompanhadas de adultos. Faz parte da realidade local crianças se deslocarem de forma independente para lugares distantes de suas residências, geralmente em turmas de diversas idades, em que o responsável é a criança mais velha, que comumente não passa dos dez anos de idade. Esse fato geralmente não se relaciona à negligência das mães das classes menos favorecidas, mas à necessidade de trabalhar, de gerir a casa, e à falta de alternativas de lazer próximas às suas moradias. As falas das oficinas comprovam a preocupação dos moradores com as crianças, aliada à consciência de que a oferta de educação, lazer e recreação são determinantes para a formação dos futuros adolescentes e adultos da favela.

Os homens possuem maior preocupação com infraestrutura - como asfalto, luz, calçadas - e com a valorização de suas casas, pensadas como moeda de troca, seguindo a determinação de uma estrutura familiar tradicional em que Ihes cabem as preocupações relativas à estrutura material da família. Embora os homens presentes na oficina demonstrem uma visão conservadora, relativa às necessidades diárias e perspectivas de futuro, devemos lembrar que grande parte das famílias de baixa renda são chefiadas por mulheres. As personalidades mais emblemáticas do Jardim Jaqueline também são mulheres. Essas constatações parciais estão ligadas a uma questão de gênero relacionada à atuação das

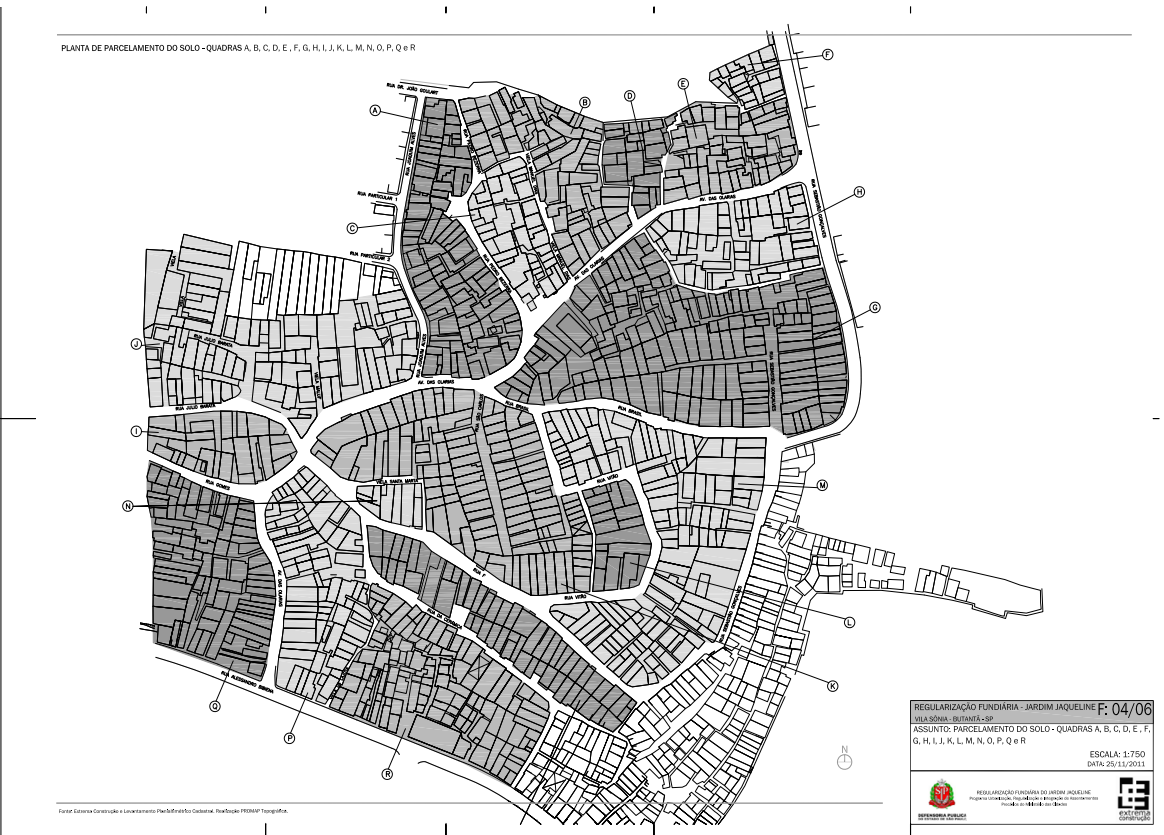

magem 13. Planta parcial do parcelamento do solo proposto para o processo de regularização fundiária. Fonte: DPESP/Extrema Construções Ltda. 
mulheres em organizações comunitárias nas periferias, que merece maior desenvolvimento fora do âmbito desta pesquisa.

As preocupações apontadas também estão relacionadas ao fator que une os elementos do grupo, que é a vontade de falar sobre a comunidade e de participar das decisões que os afetam. Se a paisagem parece um conceito estranho ao universo pesquisado, as falas revelam não somente a ausência de uma paisagem do ponto de vista do consenso fabricado sobre o termo, mas também a ausência de uma vontade radical de mudança em relação à realidade local. Enquanto as necessidades girarem em torno de pequenos ganhos sobre uma estrutura precária, não podemos vislumbrar a paisagem em seu sentido ampliado. Isso não representa a ausência da paisagem, já que as relações no lugar estão estabelecidas, mas a impossibilidade de se criar novas paisagens.

\section{SEGUNDA OFICINA - CONFLITOS E POTENCIALIDADES}

A segunda oficina com os moradores do Jardim Jaqueline foi realizada no dia primeiro de dezembro de 2012, uma semana após a primeira, e contou com a presença de 22 moradores, sem contabilizar as 7 crianças e 3 bebês, convidados na oficina anterior ou chamados informalmente pelas lideranças, por meio de contatos de encontros cotidianos com os moradores e cartaz afixado na entrada da Associação de Moradores. Um dos objetivos era agregar a percepção das crianças do Jardim Jaqueline, que conformam parcela expressiva da população da favela e que poderiam trazer uma visão "desarmada" da realidade local, com demandas que passariam despercebidas pelo público adulto.

A segunda oficina contou com público mais heterogêneo, se comparada à primeira, com moradores que nunca haviam participado de outras reuniões de representantes e algumas crianças, convidadas pelas lideranças. 0 evento contou com a presença de uma liderança que não havia participado da primeira oficina, personalidade que se destaca pelas elaboradas reflexões a respeito da atuação política da comunidade, representada pela associação de moradores.

A reunião teve início com uma espécie de inversão de papéis, onde os supostos facilitadores do evento foram surpreendidos pelos moradores, que prontamente se apropriaram da condução do debate. Uma das lideranças explicou aos moradores o significado de uma planta - planta de parcelamento, vista na página anterior - afixada na sede da Associação de Moradores, com suas ruas, vielas e divisões em lotes, com os cadastros correspondentes.

Pela explicação da liderança, ficou claro que o significado de rua e viela é compreendido pelos moradores, mas a imagem do lote ainda não faz parte do imaginário coletivo do lugar, seja porque os lotes de fato não existem de acordo com a conformação urbana da cidade formal, seja pela dificuldade de assimilação dos conjuntos artificialmente criados para efeitos de regularização fundiária. 
A liderança fez a apresentação da pesquisa e dos objetivos das pesquisadoras presentes, sem deixar de falar do processo de regularização fundiária em curso e das supostas demandas dos moradores por equipamentos públicos institucionais como creche, escola e centro esportivo para os jovens. Ela estimou a existência 20.000 moradores no Jardim Jaqueline (o cadastro indica 9.000 moradores):

[...] filha, tem muita gente, deve ter umas 20.000 famílias. É uma cidade. A gente vê, pelo mapa, o tamanho do Jaqueline. A gente que fica dentro do nosso barraco não vê, agora com o mapa dá para ver o tamanho do Jaqueline. Agora você vê pelo tamanho do mapa onde nós estamos.

\subsection{A CONSTRUÇÃO DA PROPOSTA}

Após o relato da liderança, que em nada indicava os resultados alcançados pela oficina anterior, a pesquisadora do Jardim Jaqueline se apresentou e lembrou novamente que estava representando a universidade naquele momento, e não a instituição promotora do processo de regularização, e que o objetivo daquele encontro era trabalhar com o tema da pesquisa acadêmica.

A fala da orientadora da pesquisa trouxe a leveza e aproximação pessoal necessárias à fluidez dos debates. Quando a professora justificou seu sotaque com sua origem potiguar e chamou os moradores presentes a retomarem suas origens/ histórias, os moradores, mesmo os mais calados, se manifestaram prontamente, resgatando cada um sua origem - predominantemente baiana.

Outra pesquisadora presente disse que esteve na favela no início de seu processo de adensamento, na década de 1980, na ocasião em que trabalhou na prefeitura municipal, e afirma que se surpreendeu com a mudança do lugar. Lembrou que no momento não está lá para prestar um serviço, mas para participar do processo de reflexão sobre o local e contribuir com a troca de conhecimentos entre comunidade e universidade. A retrospectiva histórica sugerida pela pesquisadora ativou um processo de lembranças dos antigos moradores, que relataram a situação encontrada quando chegaram à favela, quando o local não contava com qualquer infraestrutura. A energia elétrica teria chegado em 1982, e a água em 1986. Antes disso, os moradores mais antigos utilizavam a água da mina (nascente) ou de poços escavados nos quintais. Entre os moradores presentes existiam antigos criadores de porcos e sobreviventes do lixão existente no local onde hoje está localizado o Parque Raposo Tavares. Lembram que a primeira moradora teria sido a proprietária da olaria que operava no local. 
Sobre as dimensões físicas do Jardim Jaqueline, as lideranças se mostram informadas a respeito da posição de segunda maior favela dentro da subprefeitura do Butantã, perdendo somente para Paraisópolis. As lideranças possuem um elevado grau de informação a respeito de dados oficiais e papel das instituições na conformação local, conhecendo os cadastros da Sabesp e da Prefeitura e a cobertura da Eletropaulo. Destacam que a quantidade de estabelecimentos comerciais quadruplicou em dez anos e o perfil econômico dos moradores também. Lembram que existiam poucos carros na favela e que "Agora parece que tem mais carro que morador"9. Até certo momento, o andamento da oficina foi uma expressão da urgência das lideranças em expor a realidade local e se relacionou basicamente ao nivel de conhecimento e apreensão em relação aos dados oficiais disponiveis.

Para retomar os objetivos da oficina, podemos destacar a construção proposta pela orientadora da pesquisa, que lembrou os presentes de que a cidade em que vivemos possui uma relação fundamental com o que somos: que não habitamos somente da porta para dentro, mas também da porta para fora, onde se encontram as atividades coletivas e os encontros. Fora da casa as pessoas circulam, andam pelas ruas, se divertem, realizam festas, exercem os espaços de lazer.

Podemos afirmar que o acesso ao espaço público também é uma medida de nossa cidadania, e que a universidade possui papel significativo na construção dessa ampliação da cidadania por meio do acesso à cidade. A participação da universidade pode abrir a perspectiva do sonho de um lugar melhor - ou o que podemos chamar de utopia. Mesmo frente a todas as limitações, oriundas da dura realidade local, cerceamentos à livre circulação e opinião das pessoas, a perspectiva de futuro que um plano de intervenção participativo é capaz de descortinar supera a simples resolução de contingências ou necessidades básicas.

Foi citado o projeto desenvolvido em Pirituba, com escolas públicas, na ocasião do processo de elaboração do projeto participativo para o Parque Pinheirinho D'Água, em que foram trabalhados os espaços coletivos em suas dimensões de idealização e apropriação:

[...] as percepções, desejos e necessidades manifestos pela população e comunidade escolar ao longo do processo foram trabalhadas na perspectiva da construção de um conhecimento que tem a força da vontade popular, mas que brota da comunicação entre as partes envolvidas, no que cruza o técnico e o vernacular, o objetivo e o sensível. A troca de repertório foi crucial para os desígnios do território e pode-se considerar resultante dessa síntese. 0 desafio era justamente o de criar um processo participativo de caráter dialógico (e não apenas consultivo, muito menos assistencialista) que 
A sensação de urgência das comunidades em relação à ideia de um projeto é recorrente, porém o que se busca com projetos como o sugerido é a apropriação do conhecimento da universidade por parte da comunidade, no sentido de "empoderamento" das forças sociais para atuação dentro de um cenário de forças desiguais. Significa que as comunidades contribuem para a construção teórico/prática da universidade e ao mesmo tempo adquirem o conhecimento necessário à luta pela ampliação de um universo de direitos (direitos existentes, direito legitimados e direitos em processo de legitimação).

Saber ler mapas e plantas e discutir questões técnicas com agentes públicos. Os discursos técnicos, escondidos em representações gráficas que não são compreendidas por todos, podem levar à aceitação de algo não pactuado pela comunidade. Quem melhor entende o lugar são seus moradores e esse conhecimento é valioso para o projeto, que deve abranger o conhecimento de suas vivências cotidianas, de como as pessoas vivem de acordo com estruturas não convencionais de moradia, de ocupação urbana e de estruturação dos espaços coletivos.

Essa é a troca proposta pela pesquisa: os moradores do Jardim Jaqueline contribuem com o conhecimento a respeito de seus modos de vida e perspectivas em relação ao lugar e a universidade entra com o conhecimento técnico necessário à qualificação de uma luta e articulação já existentes. Sabemos que, por vezes, tal troca se mostra desigual, principalmente em relação a uma universidade que pouco se aproxima das realidades sociais reais da cidade, resolvendo as demandas urbanas como uma simples questão projetiva. A "construção coletiva" do conhecimento pressupõe um salto de instrução por parte da comunidade, mas principalmente por parte da universidade, que tem a oportunidade de inserção em contextos cuja complexidade não reside somente nas dificuldades de ordem físico ambiental e estrutural a serem enfrentadas, mas principalmente em relação à complexidade social envolvida. Por parte da pesquisadora, em relação à pesquisa específica, fica claro que a relação de troca foi desigual: as complexidades humanas, as costuras políticas necessárias aos avanços locais e as relações cotidianas de poder, interesses e solidariedade apreendidos no decorrer da pesquisa ainda não são passíveis de inventários ou sistematizações. Certos aprendizados ficam armazenados na experiência de pesquisadores dispostos a enfrentar realidades diversas de seus cotidianos em seus processos de pesquisa. 


\subsection{AS DEMANDAS DE SEMPRE E NOVAS POSSIBILIDADES}

Mesmo após exaustiva explanação a respeito dos objetivos e possibilidades dadas pela pesquisa em curso, os moradores questionaram quais projetos nós, pesquisadores, poderíamos oferecer em relação às carências por eles apontadas, como a ausência de locais de recreação para crianças e jovens, como um parque, onde poderia haver equipamentos. Os moradores acreditam que as crianças precisam estar ocupadas para não se envolverem com as determinações do "poder paralelo".

O trabalho com crianças realizado por uma das lideranças locais, hoje eleita como representante do Conselho Tutelar, é citado como exemplo muito significativo para muitas crianças da favela. Os moradores reconhecem a importância do espaço da Associação de Moradores como importante referencial para os moradores, mas alertam para a necessidade de projetos para afastar os jovens das drogas. Citam o clube escola (Balneário), que, pela distância, demandaria um serviço de transporte para levar as crianças.

A respeito dos "espaços coletivos", uma das lideranças chama atenção para o processo de adensamento da área, que levou à ocupação das ruas e calçadas, em áreas que seriam os espaços coletivos. O único espaço livre disponível, o campo da Rua Sebastião Gonçalves, já teria sido utilizado para finalidades de lazer e entretenimento, além do atual uso como campo de futebol. A liderança se lembra da época em que chegou ao Jardim Jaqueline e teve a oportunidade de ver parques infantis e circos no terreno. Hoje parte do espaço está tomada por barracos de madeira, utilizados como estacionamentos e pequenos comércios. Lembra que, independentemente do que está construído, o terreno não é deles. Trata-se de um terreno particular, que "não pertence à comunidade". A Associação, em parceria com a Liga das Senhoras Católicas, tentou negociar a área com o proprietário para implantação de quadras e construção de sua nova sede. Os

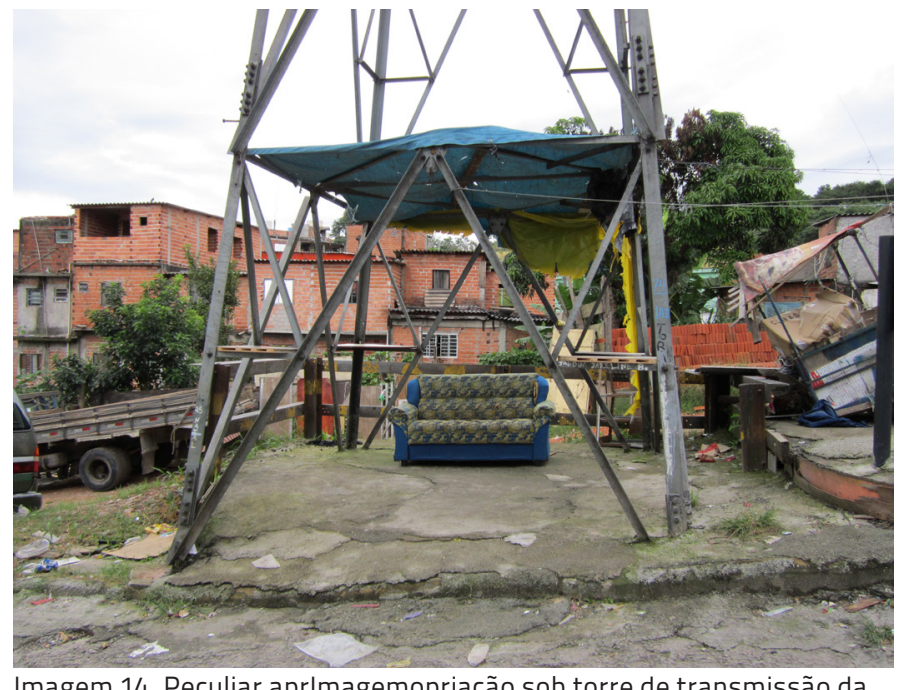

Imagem 14. Peculiar aprımagemopriação sob torre de transmissão da Eletropaulo evidencia a ausência de espaços de convivência na favela

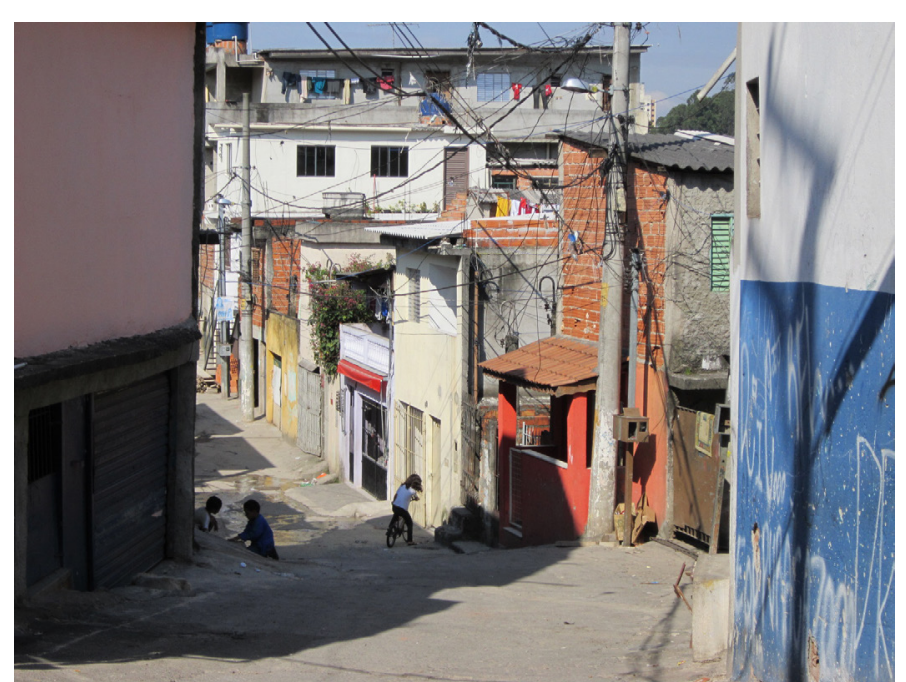

Imagem 15. Crianças brincam nas ruas estreitas sem calçadas 
moradores acreditam que, a cada dia que passa, essa "utopia" da Associação se mostra mais distante, pelo crescimento da área ocupada e pelos interesses diversos em relação ao uso do terreno.

Até a década de 1990, existiam três campos de futebol no entorno próximo da favela, restando somente o da Rua Sebastião Gonçalves. Além desse espaço, alvo de muitas disputas e esperanças, existe um campo de futebol oficial no Jardim Jaqueline, o Viana Moog, ao lado da escola de mesmo nome, cuja reforma foi promovida pela Associação de Moradores, que conseguiu verba de $\mathrm{R} \$$ 150.000, da Secretaria de Esportes, para realizar drenagem, alambrados e demais ajustes necessários para tornar o campo oficial. O campo não fica propriamente no Jardim Jaqueline, sendo distante para as crianças pequenas. 0 campo mais próximo seria o da Rua Sebastião Gonçalves. Os moradores associam os espaços de recreação para as crianças como importante ferramenta para "tirar a comunidade da droga".

Todos concordam a respeito da importância dos espaços livres e ambientes de recreação, mas teria espaço na favela para efetivação destes locais? Sobre a localização do campo, que seria mais próximo para as crianças, já existe o histórico de lutas dos moradores pela sua utilização por equipamentos comunitários. Também é citado o grande terreno particular vizinho, que com o adensamento e espraiamento da ocupação, foi separado da favela por um grande muro, "como se fosse um Muro de Berlim". Quando não existia o muro, a comunidade utilizava o grande terreno vazio como espaço de recreação, para piqueniques e futebol. Outro uso associado fala sobre o nome atribuído pela comunidade, de "campo da macumba". Quando o muro foi construído, muitos hábitos em relação ao local deixaram de existir. A "grande utopia" dos moradores seria a utilização desse espaço para recreação. Os moradores estão cientes de que a conquista desse terreno seria muito importante para um futuro projeto de urbanização da área,

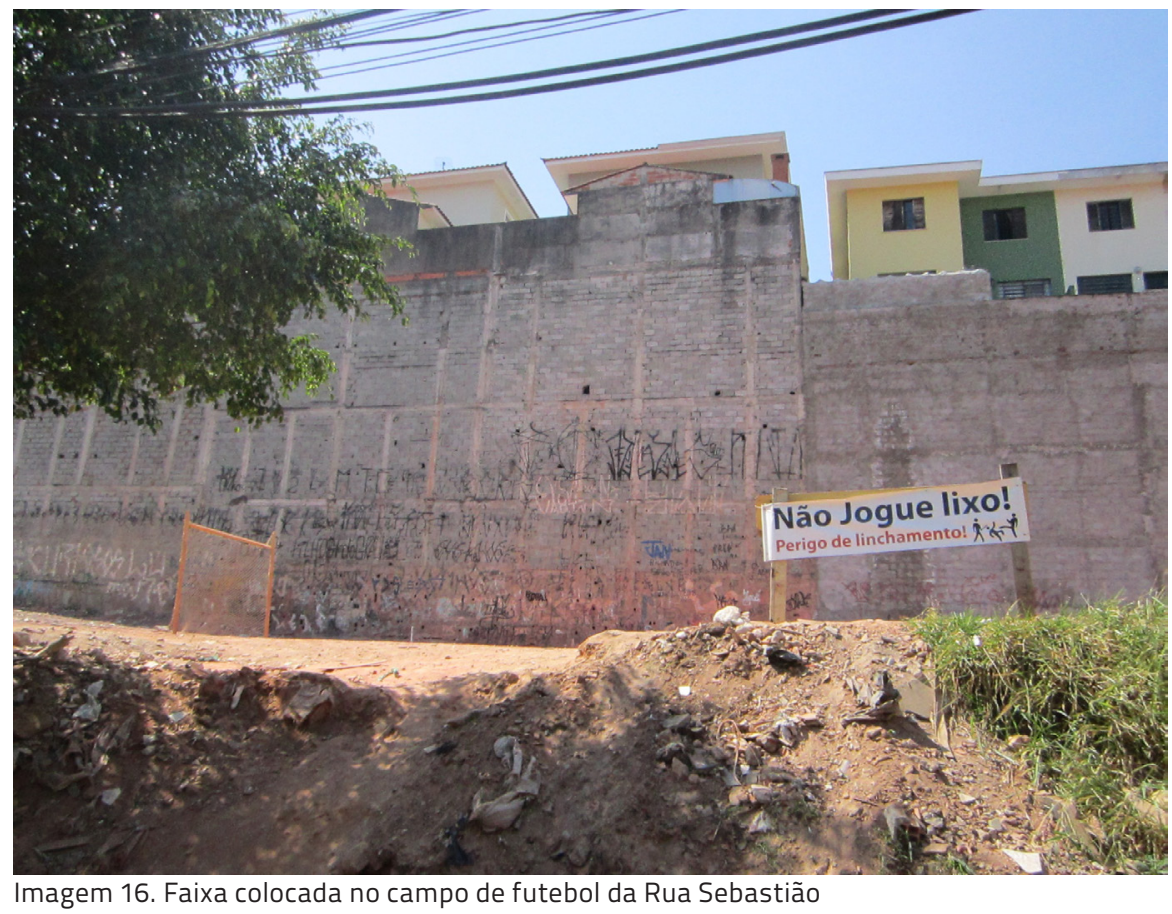
Imagem 16. Faixa colocada no campo de fute
Gonçalves indica conflitos no uso do espaço
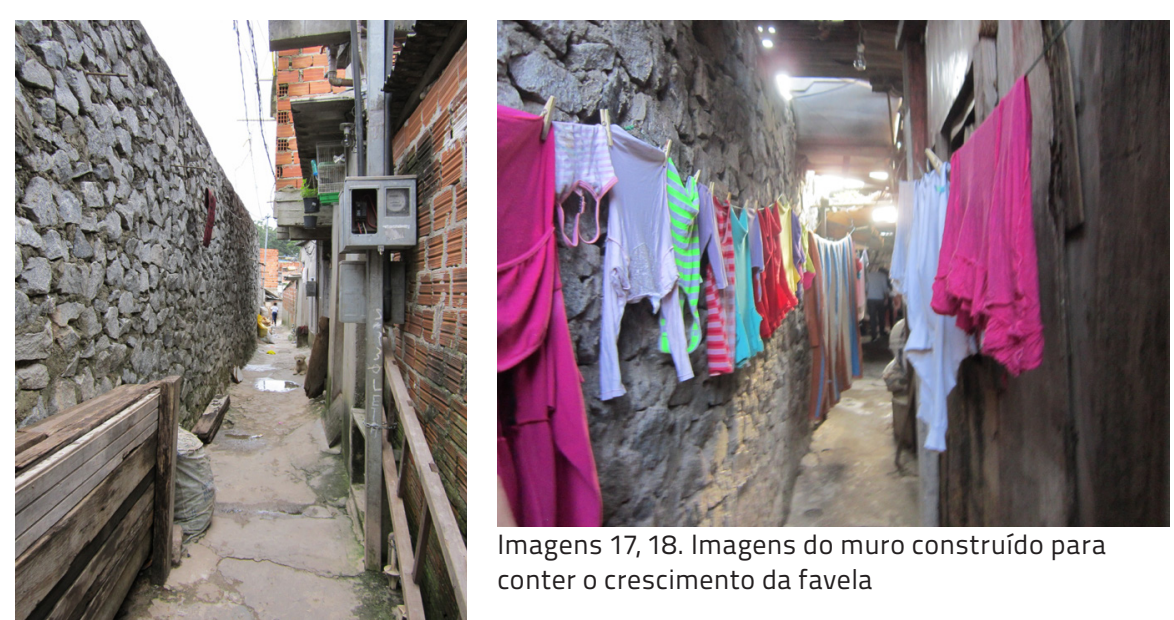

magens 17, 18. Imagens do muro construído para conter o crescimento da favela 


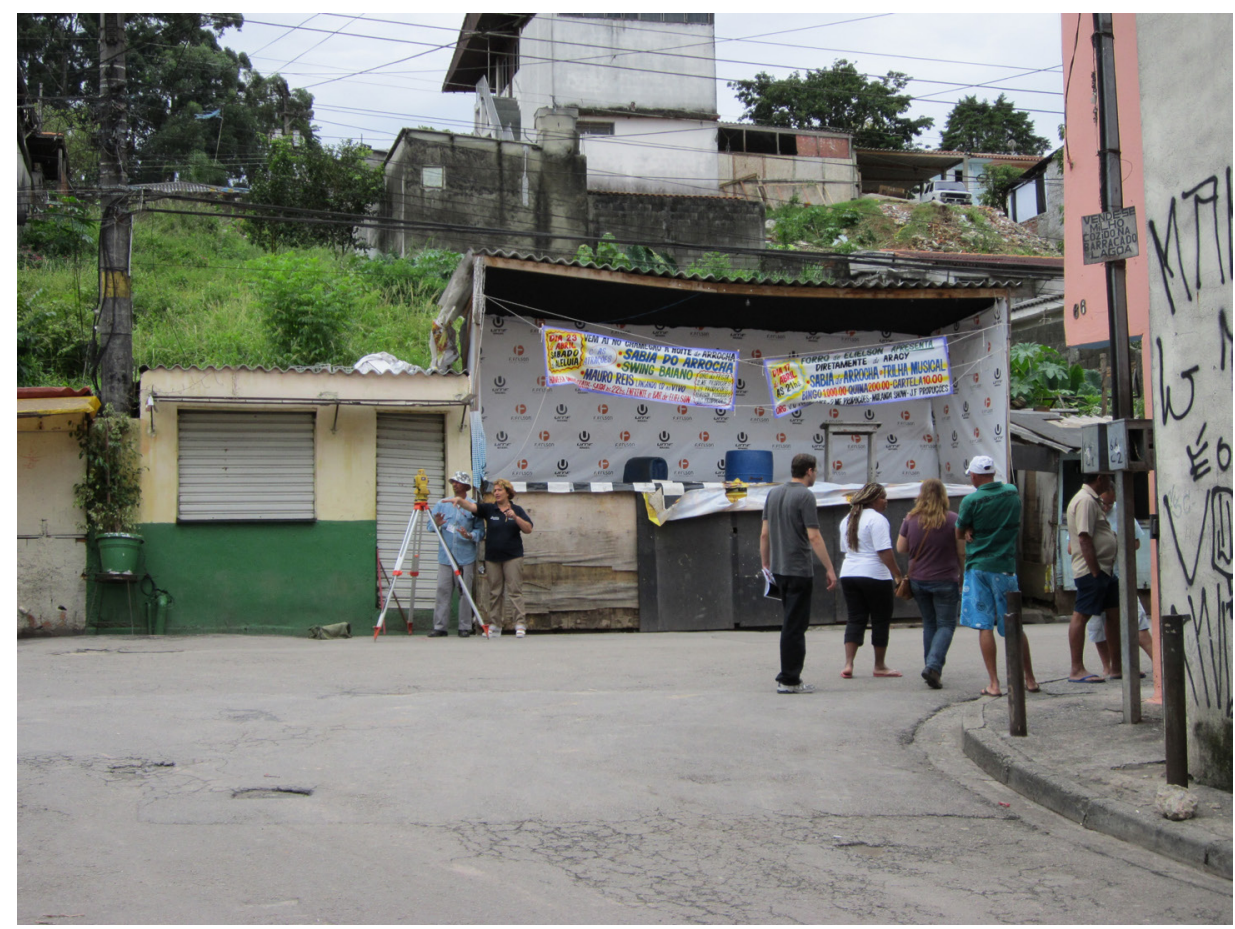

Imagem 19. Palco localizado na Rua Sebastião Gonçalves

não somente para a concretização de seus sonhos, mas também para acomodação das remoções necessárias.

As lideranças lembram que a viabilidade de um projeto urbanístico, com abertura de ruas e alargamento de vielas, dependerá de um processo muito bem trabalhado com a comunidade, já que, enquanto se fala na esfera coletiva, de forma geral, a aceitação de um projeto de intervenção é natural, mas quando se fala em "tirar a tinta da unha de alguém aqui dentro, aí vem a confusão", ou seja, o diálogo se torna difícil, pela dificuldade de se trabalhar o universo privado dentro de um trabalho coletivo. Como exemplo dessa dificuldade, cita a ausência de qualquer praça no perímetro da favela. 0 único lugar que poderia ser conside-
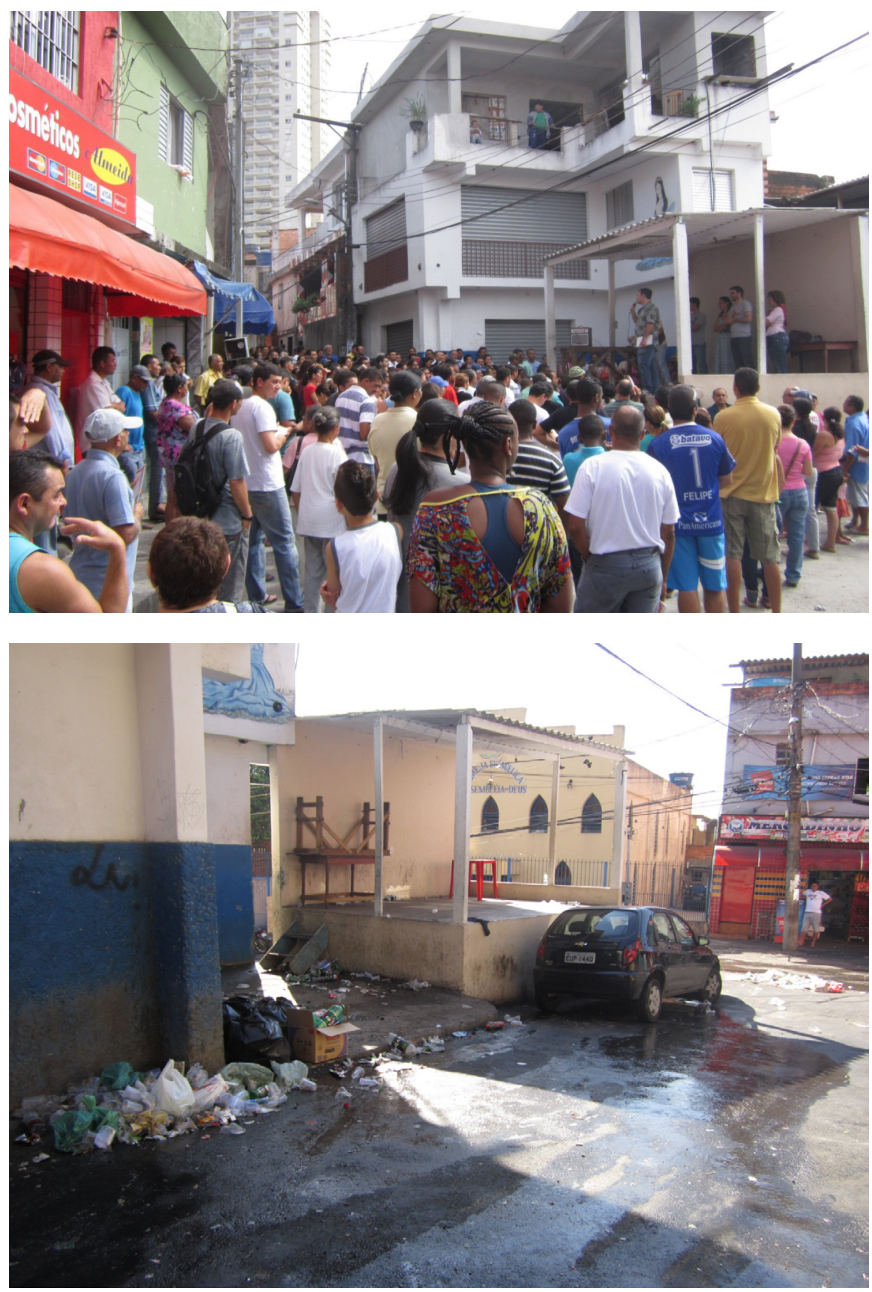

Imagens 20,21. imagens mostram diversos usos dados ao palco da princesinha, localizado em um pequeno largo e importante referência na favela 
rado uma praça, e que um dia já foi, seria o Largo da Princesinha, onde hoje está implantado um palco de madeira, utilizado para festividades, assembleias e outras manifestações políticas. Os moradores lembram que o local de fato era uma praça, marcada pela presença de um grande eucalipto, com bancos ao redor, e que, com o tempo, o espaço foi "invadido" por novas moradias. Sobrou somente o palco, que é partilhado pela comunidade, Associação de Moradores, palanque político e diversos eventos, desejáveis ou não à maioria dos moradores.

\subsection{AS DETERMINAÇÕES LOCAIS - SOBRE A "NOSSA CULTURA"}

Questionados sobre as festas, os moradores disseram que são realizadas festas com música todas as sextas e em alguns domingos, no palco da Rua Sebastião Gonçalves. Para explicar melhor a "questão cultural" local, uma das lideranças lembra que as primeiras festas do Jardim Jaqueline eram quermesses, realizadas no Largo da Princesinha e nas ruas Sebastião Gonçalves e Alessandro Bibiena. Com o tempo, comerciantes começaram a se unir para organizar forrós em torno de seus estabelecimentos comerciais, até que, com a consolidação da estrutura do poder vigente local, tiveram início os "pancadões", muito frequentados pelos adolescentes moradores da favela e do entorno. Os "pancadões", além de atender aos interesses da estrutura de poder instituída, movimentam o comércio local: "Essa é a nossa festa". Existe uma simbiose entre "poder paralelo" e comércio local, que se beneficia do público interno e externo, que frequenta os eventos promovidos pela chamada "atividade". Quando as festas são realizadas por iniciativa dos donos dos bares, são frequentadas pela população local. Mas os "pancadões" atraem público de todos os lugares. Enquanto esses eventos giram a economia local, também tiram o sono dos moradores, que lamentam as noites mal dormidas e as cenas presenciadas quando precisam se deslocar na favela nesses momentos.

Na ocasião da oficina, o "pancadão" estava suspenso devido à intervenção da polícia, no Jaqueline e em outras comunidades. Na visão das lideranças, o que mais incomodava os moradores não era o "pancadão" em si, mas o ambiente de tumulto e brigas relacionado ao evento. Mais do que o "pancadão", o que incomoda na favela é a atuação da polícia, com imposição de toques de recolher, desrespeito aos moradores, sem distinção de gênero ou faixa etária, com agressão física e psicológica, e marginalização. Os moradores se sentem reféns dentro de suas casas, pela restrição de locomoção. Consideram que a polícia utiliza-se de determinados comportamentos para se promover, já que eles (a polícia), juntamente com o poder instituído, sabem "quem é quem" dentro da comunidade ${ }^{10}$.
100 fato de todos os atores envolvidos nas dinâmicas cotidianas da favela saberem "quem é quem" é muito difundido nas falas dos moradores das periferias e em trabalhos acadêmicos que procuram discutir o universo de pertencimento do chamado "sujeito periférico". Cf. D'ANDREA, 2013. 


\subsection{EQUIPAMENTOS PÚBLICOS E PARTICIPAÇÃO SOCIAL}

Questionados a respeito dos diversos equipamentos públicos localizados no entorno, como o CEU, e se esses equipamentos eram utilizados, os moradores reconheceram a existência dos equipamentos, mas afirmaram que são insuficientes para atender uma comunidade em constante crescimento e que conta com parcela expressiva de crianças e jovens. A creche mais próxima é o CEI Jardim Jaqueline, mas existem outras creches no entorno, como: a Fernando Pessoa, na Rua Denis Chaubet; a João Negrão, uma EMEl; e a Sagrado Coração de Jesus.

Mas, apesar da quantidade de equipamentos, a demanda para crianças de zero a seis anos cresceu muito no Jardim Jaqueline, e hoje a oferta não atende a essa demanda, que também se aplica ao ensino fundamental. Existem mais crianças no Jardim Jaqueline do que o número de vagas nas unidades próximas. A oferta de equipamentos do entorno nos últimos anos não acompanhou o crescimento do Jardim Jaqueline, que sofre processo de "superlotação", de acordo com a visão das lideranças. Elas citam o comprometimento necessário da gestão municipal no atendimento a essa demanda e exemplificam o caso do CEI Jardim Jaqueline, que, com um bom projeto físico e pedagógico, poderia aumentar sua oferta de vagas.

Sobre a atuação da Associação de Moradores com crianças e jovens, foi citada sua parceria com a Liga das Senhoras Católicas no projeto educacional, social e cultural "Só Alegria", que ofereceu aulas de inglês, espanhol, reforço escolar e teatro, como parte de um processo de formação cultural abrangente. Uma das lideranças presentes frequentou o curso do Senac de Agente de Desenvolvimento Local, que trouxe subsídios para o trabalho com as crianças. Foi relatada maior fragilidade social em relação ao público infantil da favela, que não possui qualquer opção de entretenimento, enquanto os jovens "vão para o forró, enchem a cara" e os adolescentes vão para o Shopping ou frequentam o "pancadão".

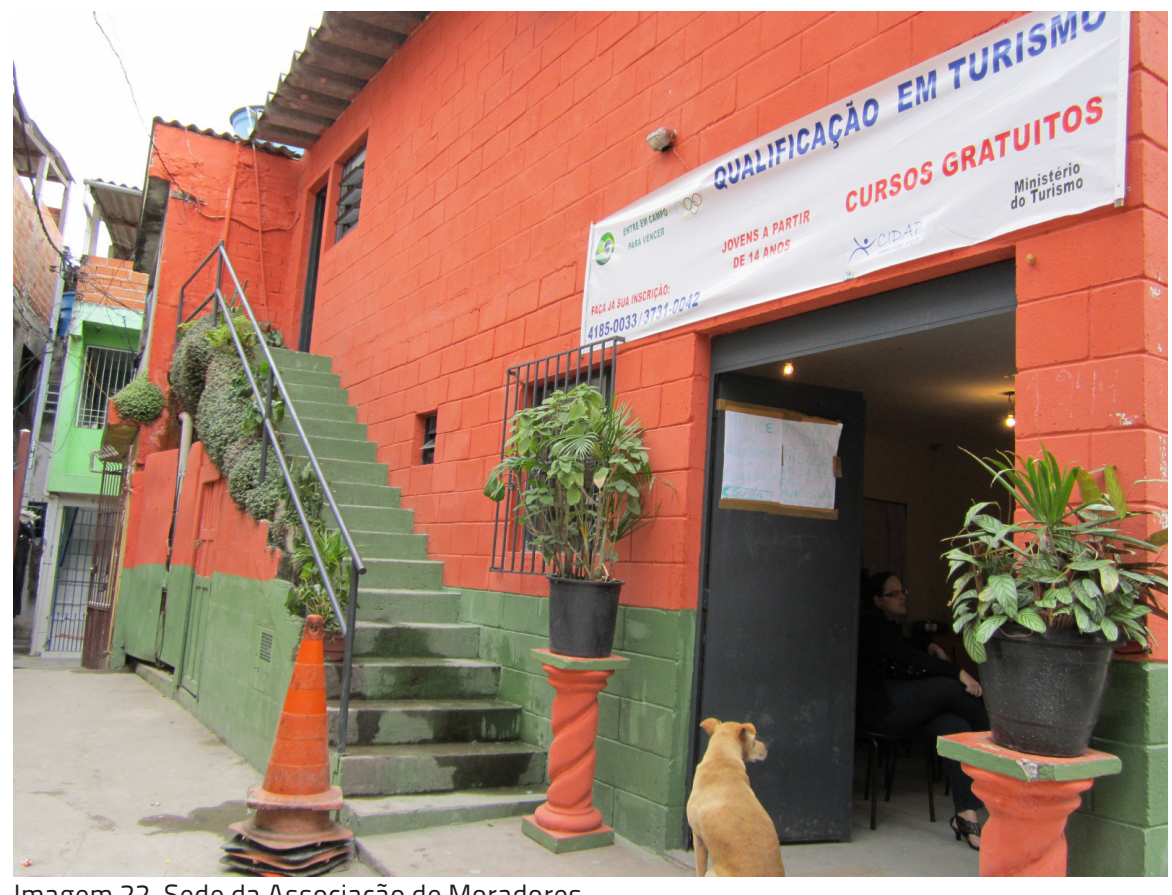

Imagem 22. Sede da Associação de Moradores 
Como opção de lazer para a família foram citados o Shopping e o Parque Raposo Tavares, nessa ordem. Apesar da proximidade, o Shopping foi considerado como uma opção economicamente inviável para famílias com duas, três e quatro crianças, já que os pais não teriam dinheiro para custear os desejos das crianças imersas em um centro de compras. A população não frequentaria o Parque Raposo Tavares devido à falta de atrativos no local. Na visão das lideranças, não existiu um projeto que incluísse as necessidades dos moradores. Em relação ao Centro de Referência em Segurança Alimentar e Nutricional, apesar da proximidade, os moradores não se identificam com o lugar. O Telecentro, que fica nas dependências do Centro de Referência, foi conquistado pelos moradores após muitas reivindicações, mas não é utilizado. A resistência encontrada em relação à utilização desses espaços estaria relacionada à gestão dos equipamentos, feita sem a participação local. A comunidade não teria se apropriado dos equipamentos. A falta de utilização do espaço se contrapõe à intensa presença dos moradores no espaço da sede da Associação de Moradores, mesmo na época em que o espaço era um barraco de madeira. A utilização do espaço estaria associada à atuação das lideranças na mobilização da população e ao sentimento de pertencimento dos moradores em relação ao local.

Foi citado o fato de que o Centro de Referência, inaugurado há seis anos, com estrutura adequada para receber os moradores do Jardim Jaqueline, foi apropriado pela população dos bairros vizinhos, como o Jardim Previdência. A demanda do Jardim Jaqueline era de construção de uma creche, mas devido ao histórico de aterro sanitário na área do Parque, a prefeitura alegou que o local onde hoje se encontra o Centro de Referência não poderia receber uma creche. Os moradores esperavam um espaço que pudesse ser utilizado pelas crianças, mas, de acordo com eles, a programação do local não é voltada para o público infantil. Muitos moradores fazem atividades físicas fora da favela, em equipamentos localizados em praças do entorno. Foi sugerida a incorporação de equipamentos de ginástica no entorno do Centro de Referência, como parte de um possivel projeto voltado para os idosos e as crianças. Existiriam projetos sociais voltados às crianças nas proximidades, mas eles não seriam frequentados pela dificuldade de deslocamento11.

\subsection{A NECESSIDADE DE UM PROJETO E A POSSIBILIDADE DE DESLOCAMENTOS}

Os moradores foram questionados a respeito de suas percepções quanto à possibilidade de remoções dada por um projeto de urbanização da área. Foi colocado que, mesmo realizado da melhor forma, um projeto acaba indicando a necessidade de deslocamento de moradias. Analisando a experiência encontrada no Jardim Jaqueline em relação à utilização dos espaços coletivos, onde os pedestres, as crianças brincando e os carros disputam o mesmo espaço, alertamos para a
11 Vemos novamente como o dentro e o fora estão fortemente delimitados no imaginário dos moradores locais. Espaços que podem ser considerados próximos à favela não são considerados como equipamentos da favela. Apesar da intensa circulação pedonal verificada dentro da favela, com muitas crianças brincando nas ruas, dividindo perigosamente o espaço com os carros, a apropriação dos espaços externos é muito limitada. No Capítulo 3, procuramos

entender essa lógica, que se relaciona à realidade local de ausência de espaços de lazer intrafavela, mas que também se relacionam a referenciais de enclausuramento do espaço urbano, partilhados por diversas classes sociais. 

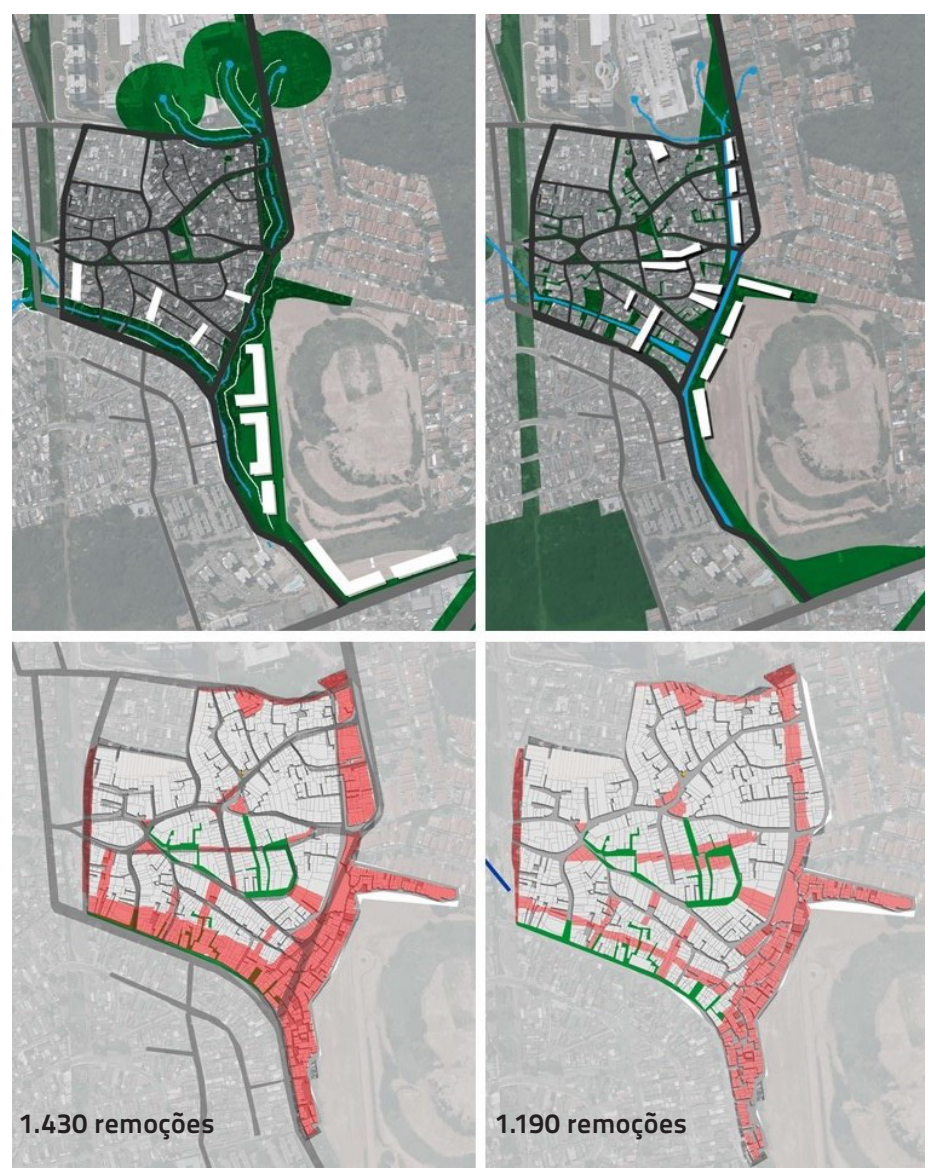

Imagem 23. Propostas de intervenção realizadas no âmbito do processo de

regularização fundiária indicam cenários possiveis, com remoções totais nas APPs e remoções parciais, considerando áreas mais precárias e manutenção de mora-

necessidade de qualificação dos espaços públicos e não somente de abertura de vias e de enfrentamento das áreas de risco. dias em áreas consolidadas

Os moradores relataram que ocorriam muitos desabamentos na favela, mas, com a substituição da madeira pela alvenaria, os desabamentos se tornaram raros. Quanto ao rio, a partir do momento em que foram construídas casas sobre seu curso, ele passou a ser invisível. Nesse momento, percebemos o significado positivo atribuído ao processo de ocultamento do córrego, visto como fator de insegurança e precariedade pelos moradores. A relação simbólica estabelecida com os cursos d'água é um importante dado a ser problematizado em nossa pesquisa. Foi questionado se a comunidade estaria disposta a participar ativamente do processo de elaboração de um projeto no qual famílias teriam de sair. Instruímos os 
moradores no sentido de que existem projetos executados pelo poder público em que os moradores são retirados sem garantias de uma moradia definitiva, recebendo indenizações insuficientes para a conquista de uma moradia digna ou sendo deslocados para locais muito distantes em relação aos seus antigos locais de moradia. Chamamos atenção para a relatividade das distâncias. 0 próximo, para o carro, pode ser muito distante, para o pedestre.

As lideranças acreditam que a questão das remoções será muito complicada, já que, no nível das idealizações, todos concordam com o que é apresentado, mas quando se fala de questões individuais, ninguém está disposto a abrir mão de nada. Exemplificam com a questão de uma lixeira, retirada de uma região com muitos pontos comerciais (barracos de madeira utilizados como pontos comerciais que estão ocupando terreno na Rua Sebastião Gonçalves) e colocada próxima a uma creche. Acreditam que "não se faz um omelete sem quebrar os ovos", mas sabem que não será fácil e que alguns enfrentamentos serão necessários. No momento da discussão de um projeto oficial "todo mundo vai deixar de pensar o coletivo e cada um vai defender os seus interesses". Os moradores possuem a consciência do peso dos valores individuais nas determinações locais.

Nesse momento, cada morador começa a enumerar as questões que condicionariam a aceitação de uma provável remoção: quem está na área há muito tempo ("Quem mora aqui há 40 anos não vai querer ceder o seu espaço"); quem possui estabelecimentos comerciais ("Quem tem sua renda aqui vai fazer o quê?"); e quem possui moradias amplas e bem estruturadas. O tema desperta a atenção dos moradores, que falam ao mesmo tempo. Reconhecem que a simples ausência de calçadas denuncia a necessidade de abertura das vias.

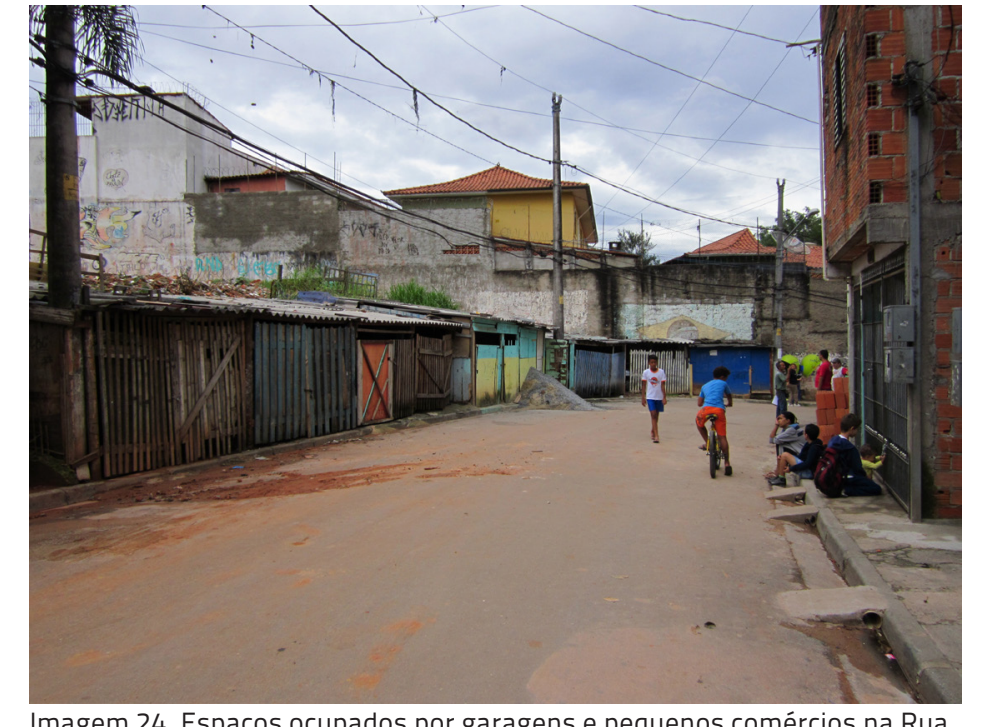

Imagem 24. Espaços ocupados por garagens e pequenos comércios na Rua Sebastião Gonçalves

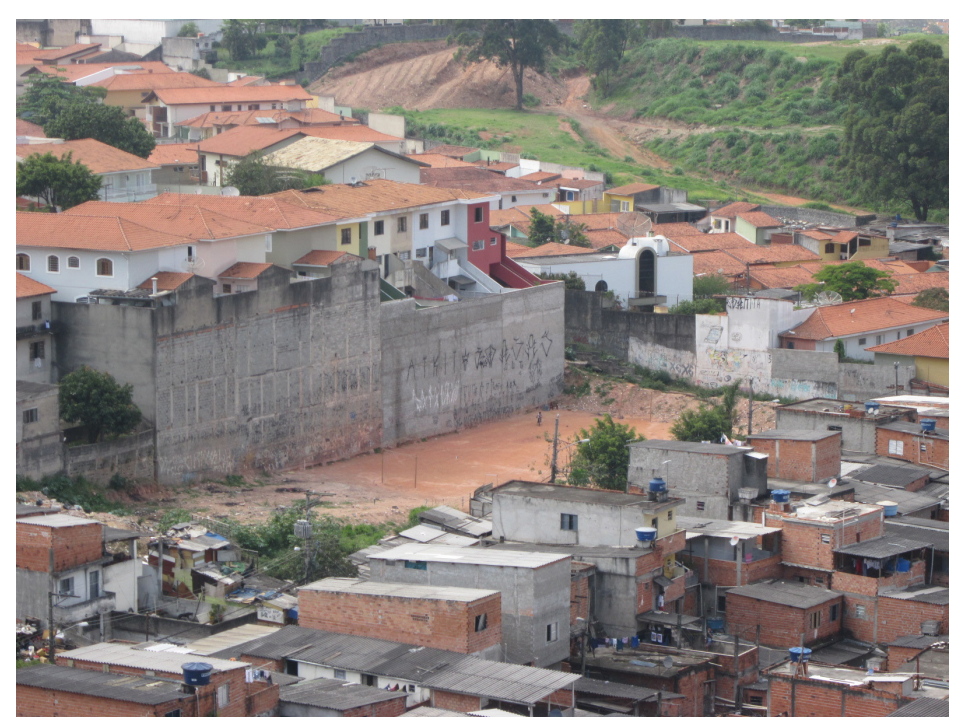

Imagem 25. Vista do único espaço vazio dentro da favela, utilizado como campo de futebol, na Rua Sebastião Gonçalves 


\subsection{OS INTERESSES INDIVIDUAIS E O SACRIFÍCIO DO ESPAÇO COLETIVO}

Como exemplo dos constantes conflitos de interesse existentes, citam o processo de ocupação dos espaços livres restantes, feito de acordo com interesses individuais dos comerciantes, que abrem novos pontos a cada dia, e dos proprietários de carros, que querem abrigar seus meios individuais de deslocamento. Reconhecem que, apesar da perda de qualidade dos espaços, a comunidade necessita dos estabelecimentos comerciais: "A gente não é contra nada disso, porque é a maneira que a gente tem de se virar, de girar o capital". Tal fala resume as tensões locais entre interesses coletivos, representados pelos interesses legítimos de uma coletividade enclausurada, como a necessidade de espaços livres e determinações de ordem social e econômica impostas dentro de suas realidades. A questão da caçamba de lixo é somente um dos exemplos de como os conflitos se resolvem na comunidade. Os comerciantes incomodados conversam entre eles, decidem retirar a caçamba da frente de seus estabelecimentos, conversam com o mandante de plantão e não consultam os moradores do local sobre para onde querem levar a caçamba. A liderança chama atenção ao fato de que a nova localização da caçamba não é estratégica para a os moradores locais, que precisam andar mais para jogar o seu lixo.

No ano passado, a Associação de Moradores conseguiu o recapeamento de todas as ruas do Jardim Jaqueline, fato que deixou os moradores muito satisfeitos. Com o entusiasmo, resolveram aproveitar que a rua estava cuidada para retirar os pontos de lixo das vielas, fato que acabou sobrecarregando ainda mais a caçamba da Rua Sebastião Gonçalves, que hoje fica em frente a uma creche. Apesar da existência de moradores que vivem da reciclagem do lixo, o Jardim Jaqueline não pode ser considerado como exemplo de reciclagem. Podemos ver, por meio da composição das caçambas, que todo o lixo é destinado da mesma forma ou que a preocupação de poucos em relação à reciclagem se dilui frente ao comportamento da maioria ${ }^{12}$. Essa não é uma constatação de um comportamento presente somente na favela, como querem transmitir diversos setores da nossa sociedade. A diferença é que, na cidade formal, muitas famílias ainda dispõem de "subordinados" que transportam e destinam seu lixo. Precisamos refletir que, na cidade formal, existe uma logística de deslocamento do lixo produzido que impede seu acúmulo na porta da casa das pessoas, mas nem por isso representa menores volumes produzidos.

Um projeto para a área dependeria de muito diálogo. "Deve ser uma coisa muito clara e muito certa." A pesquisadora lembra que, pelo que já presenciou nas reuniões com os moradores, o Jardim Jaqueline está longe de ter um consenso a respeito da melhor forma de promover a urbanização da área. Muitos moradores escolheriam o modelo de "terra arrasada" com a construção de edifícios. A pesquisadora lembra-se de uma das apresentações da empresa que realizou os trabalhos
120 Jardim Jaqueline possui um Ecoponto e a maior cooperativa de lixo da cidade - a Cooperativa Vira Lata. Em maio de 2013, a favela recebeu o projeto São Paulo + Limpa, um evento promovido pela Rede Globo, em parceria com ONGs, escolas e prefeitura. Na ocasião, os moradores puderam participar da "transformação do seu bairro", por meio de oficinas educacionais e atividades sobre sustentabilidade, coleta seletiva e reciclagem do lixo. 0 marco do evento foi a construção de uma floreira em uma calçada reconhecida como ponto de grande acúmulo de lixo. 
técnicos para o processo de regularização fundiária, onde foram apresentados diversos modelos de urbanização, com exemplos já realizados.

As lideranças acreditam que os moradores, ou a maioria deles, já chegaram ao entendimento de que a melhor maneira de se urbanizar a área seria a manutenção das áreas mais consolidadas, com melhorias de infraestrutura, e retirada parcial de moradias na área da CIT, área mais recente e pouco consolidada, que conta com a existência de muitas moradias de madeira. Acreditam que, para as famílias que ocupam locais inadequados, os prédios se aplicariam. A liderança lembra que existem áreas consolidadas sobre o córrego e que, nessas áreas, o processo de convencimento pode ser mais difícil, já que, pelo tempo de moradia, muitas famílias se habituaram a morar ali. Os conflitos também podem surgir pelas diferentes metragens entre as moradias. A maioria acredita que a manutenção do maior número de moradias possível minimizaria os conflitos gerados por uma proposta de intervenção.

\subsection{PRINCIPAIS PONTOS DE REFLEXÃO}

O primeiro ponto que devemos ressaltar em relação à segunda oficina com os moradores diz respeito à presença de uma das lideranças, que não estava presente na primeira oficina. Como ela mesma relatou, preferia ser a última a falar, já que suas intervenções seriam demasiado longas e que ela poderia não dar oportunidade aos outros presentes de exporem suas questões. Ocorreu claramente o anunciado. Apesar de suas valiosíssimas intervenções - beneficiadas pela complexidade de suas análises a respeito do Jardim Jaqueline - serem fundamentais ao processo de apreensão do lugar por parte das pesquisadoras, ficou claro que parte dos moradores se sentiu intimidada pela eloquência da liderança.

Em qualquer contato com moradores de favelas, sabemos que as lideranças exercem papel de destaque, e acabam determinando ações, comportamentos e opiniões dos moradores, sem falar nos casos em que existem conflitos entre diversas lideranças em uma mesma favela, ou comunidade, como preferem seus moradores. No caso do Jardim Jaqueline, as lideranças que representam a associação de moradores são amplamente reconhecidas dentro da comunidade e fora dela, se considerarmos a favela vizinha. Mesmo com o reconhecimento e ausência de conflitos anunciados entre moradores e lideranças, pudemos notar, na oficina, divergências entre falas, além da participação predominante da liderança.

Antes de enumerar as diferenças, temos que ressaltar as convergências de opiniões, que se deram em torno do apontamento das demandas concretas em relação à favela, principalmente em relação às vagas em equipamentos públicos, como creches, escolas e espaços de recreação. Fica claro que a comunidade se une em torno de objetivos comuns bem claros 
e mensuráveis. As diferenças se dão nas questões que resvalam no equilíbrio instável encontrado na favela, que passa pelas costuras estabelecidas entre lideranças, comerciantes e poder local instituído. Não se tratam de associações entre as instâncias citadas, mas o diálogo necessário para a garantia do equilíbrio interno da comunidade. É notório dentro de comunidades controladas pelo "poder paralelo" que qualquer intervenção externa, seja de visitantes desconhecidos, pesquisadores ou intervenções do poder público deve ser previamente autorizada. Em um ambiente em que todos se conhecem, chama atenção a colocação de que a população não precisa ser criminalizada de forma indiscriminada, considerando a atuação da polícia na favela, já que todos sabem "quem é quem" dentro da comunidade.

A realização dos "pancadões" expõe um ponto nevrálgico dentro da favela. Podemos afirmar que grande parte dos moradores não pactua com esse tipo de entretenimento, se sentindo lesados em relação aos seus direitos individuais. Inúmeros inconvenientes foram relatados, como excesso de barulho, violência e inconformismo em ver o público jovem local em situações degradantes decorrentes do consumo de drogas. Essa tensão verificada entre os moradores é relativizada pela liderança, que lembra que os arranjos existentes dentro da favela, incluindo festas do "poder paralelo" e crescente processo de ocupação dos espaços restantes por pontos comerciais, fazem parte de uma dinâmica de sobrevivência: "É a maneira que a gente tem de se virar, de girar o capital". Cabe aqui uma colocação feita em outra circunstância, em que a liderança deixa claro, com uma fala muito segura e incisiva, "que não se trata do certo ou do errado. Trata-se da nossa realidade".

Para além das costuras sociais existentes, que devem ser respeitadas pelo simples fato de se tratar de uma realidade dificilmente apreendida por quem olha de fora, podemos constatar que os moradores se sentem nitidamente sufocados pelo contexto de intenso adensamento verificado e pelos conflitos entre interesses diversos, entre eles, o do poder local instituído.

As discussões em torno do espaço do campo de futebol adaptado no terreno da Rua Sebastião Gonçalves também suscitam diferentes opiniões, entre a apropriação do terreno para a construção oficial de um campo, de um equipamento de lazer, de uma creche ou de uma nova sede para a Associação de Moradores. O ponto de convergência é de que o terreno deve ser apropriado pela comunidade. Esse exemplo de disputas por demandas dá o tom das dificuldades a serem enfrentadas em um projeto de urbanização. Essa questão da escolha de uns equipamentos em detrimento de outros, que aparentemente está internalizado nas falas quando os moradores interrompem uns aos outros para colocar as melhores opções entre as demandas existentes, será questionada adiante. Avalia-se que não faltou clareza na exposição dos objetivos da pesquisa e intenção dos pesquisadores, e que, se em alguns momentos os moradores se afastavam deliberadamente dos objetivos 
propostos, era para expor suas aflições em relação à insegurança de suas posses, em um primeiro momento, e a respeito das questões de ordem social e econômica que se sobrepõem a qualquer aspiração por novas subjetividades. Apesar de suas preocupações imediatas serem legítimas, avalia-se que a importância dada às tais questões pode manter a comunidade investigada apartada de um processo mais significativo de ampliação de seus direitos, relacionados não somente a moradia e equipamentos, mas à apropriação de novos modos de vida e de direitos em relação à cidade.

A relação entre lideranças comunitárias, poder local e polícia se mostra muito complexa e fugidia no que toca a análises parciais. A polícia não se mostra uma aliada em relação às questões políticas que norteiam a atuação das lideranças, ao contrário do poder local instituído, que mesmo não sendo um aliado quando se trata de interesses dos moradores, necessita da manutenção de uma posição de equilíbrio dentro das relações sociais internas à favela. Nesse sentido, existe o diálogo com "os chefões" do poder local, para viabilizar a atuação das lideranças de fora para dentro, em relação às parcerias com universidade e poder público, que contam com o aval das estruturas de controle interno para sua atuação.

Esse equilíbrio interno, que chamamos de equilíbrio instável, se mostra mais conflituoso em relação à realização dos "pancadões", que não são aceitos pela maioria da população, mas que não são questionados pelas lideranças, em nome desse equilíbrio. Os moradores, de forma geral, gostariam que as festas da favela tivessem maior controle, inclusive em relação à entrada de crianças e adolescentes, que são as maiores vítimas do consumo de drogas. A atuação da polícia é muito questionada pelos moradores, que relatam casos de pagamento de "dízimos" por parte dos traficantes para a polícia e episódios de violência policial indiscriminada contra moradores.

\section{A CIDADE LEGAL OLHA A FAVELA}

Considerando que a favela estudada conta com um forte sentido de "comunidade", onde podemos perceber "muros" imaginários, que delimitam o Jardim Jaqueline e produzem limites exatos entre o dentro e o fora, alguns atores do "Iado de fora" foram consultados a fim de formar uma rede de referenciais em relação à paisagem local, onde o conjunto Jardim Jaqueline, Morro da Fumaça, condomínio Espaço Raposo e Shopping Raposo perfazem uma unidade perceptível em relação à escala local. Para a investigação do entorno imediato da favela, consultamos um segurança do Shopping Raposo Tavares, uma moradora do condomínio Espaço Raposo e uma moradora da favela vizinha, o Morro da Fumaça, além de um morador de um bairro regular horizontal vizinho. As opiniões em relação ao Jardim Jaqueline, de forma geral, giram em torno do imaginário comum a respeito dos moradores de favelas, relacionadas à violência, insegurança e desvalorização do lugar. Mas, 
em um segundo momento, as qualidades da maioria dos moradores da favela são reconhecidas. O segurança do Shopping alertou a pesquisadora sobre o perigo de tirar fotos da favela, que "estaria repleta de 'olheiros' e gente perigosa".

Questionado sobre a possibilidade de conhecer pessoalmente os moradores da favela, o segurança reconhece que a maioria dos moradores trabalha para sobreviver, muitos deles no próprio Shopping, e que a "parte ruim" seria uma minoria. Os moradores residentes de bairros regulares do entorno, representados por moradores do Jardim Celeste e Jardim das Vertentes, associam a favela à violência, não adentrando seus limites. Relatam episódios de violência associados a moradores da favela e dizem que sua proximidade gera sensação de insegurança, que pode ser comprovada pelos altos muros e sistemas de segurança individuais existentes nas casas.

A entrevista mais significativa foi realizada com a moradora do condomínio Espaço Raposo, condomínio fechado que comporta moradias de classe média alta. Além de sua relação com a favela vizinha, a moradora expôs sua relação com a cidade, expressando uma forma particular de percepção e apropriação, recorrente em diversas classes sociais desde a perpetuação do modelo de condomínios fechados em São Paulo. Moradora do condomínio há cerca de um ano, ela veio da Pompeia, bairro localizado na Zona Oeste de São Paulo, em uma área central, com diversidade de comércios e serviços de rua, onde os deslocamentos eram realizados a pé em grande parte de seu tempo. Com o crescimento da família e a necessidade de um espaço maior, a possibilidade de morar no condomínio, mesmo considerando a distância em relação ao seu antigo contexto social, se mostrou vantajosa no momento, considerando o alto valor do metro quadrado para um apartamento equivalente, de $150 \mathrm{~m}^{2}$ com quatro quartos, na Pompeia. O diálogo com a entrevistada mostrou, além de indícios a respeito da relação dos moradores do condomínio com a favela, um universo referencial em transformação em relação à cidade.

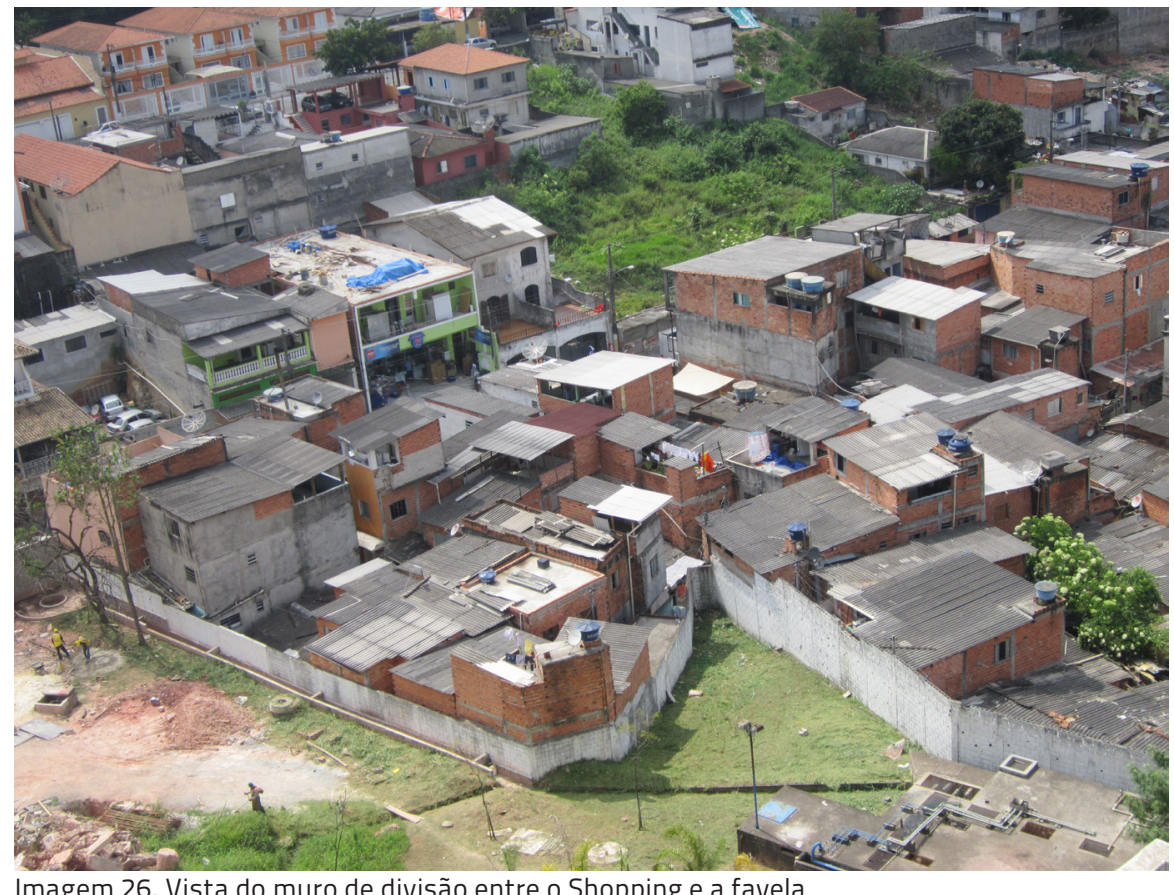

Imagem 26. Vista do muro de divisão entre o Shopping e a favela 


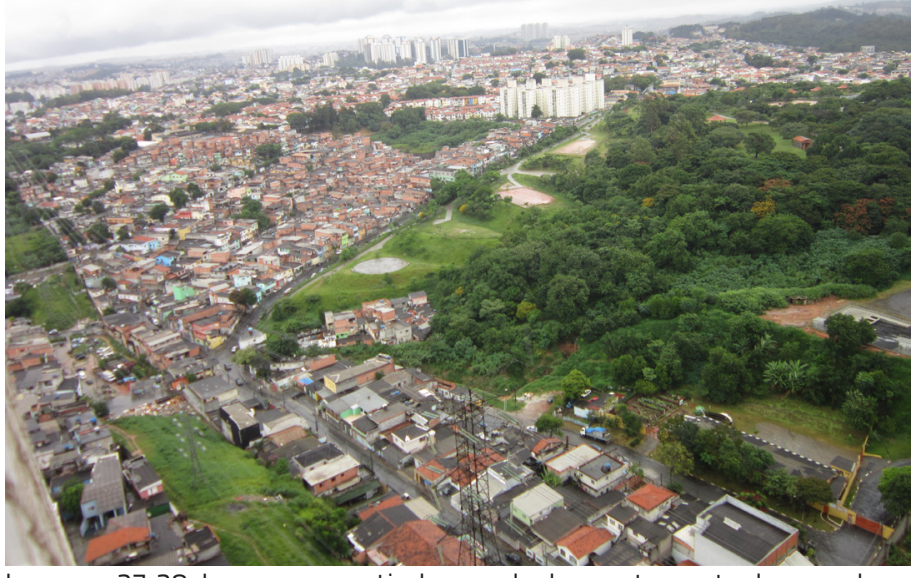

Imagens 27, 28. Imagens a partir da sacada do apartamento da moradora do conjunto Espaço Raposo

Quando a moradora abandona uma rede de relações e formas de apropriação da cidade, para se estabelecer em um local em que tais relações são drasticamente cortadas, dando lugar a relações estabelecidas dentro de um condomínio, não é somente a localização dentro da cidade que muda, mas principalmente o estilo de vida. As filhas, que frequentavam clubes, academias e espaços de lazer diversos passam a fazer todas suas atividades no condomínio (judô, dança, musculação, hidroginástica, pilates, disponíveis das 7h à meia-noite, além de aulas de inglês). O Shopping ao lado se coloca como extensão do condomínio, com a presença de um segurança na transição entre ambos. A moradora afirma que não sente necessidade de sair de casa e acredita que perdeu em termos de localização, mas ganhou em qualidade de vida ${ }^{13}$. Afirma que está completamente adaptada à nova localização e não gostaria de voltar para o antigo local de moradia. O ideal da família é se mudar para Cotia, para uma casa, quando os filhos crescerem.

O condomínio conta com muitas famílias com filhos pequenos, que interagem nos espaços dedicados às crianças do condomínio. A moradora consultada diz se sentir satisfeita com a possibilidade de seus filhos levarem amigos para casa nas refeições, como ela fazia em sua infância. Essa liberdade de encontrar amigos e transitar pelos espaços do condomínio deixa a mãe tranquila em relação à segurança e sociabilidade dos filhos. A moradora cita a presença significativa de famílias
130 Capítulo 3 traz uma investigação a respeito do estilo de vida adotado pelas diversas classes sociais em São Paulo, com seu processo de enclausuramento e apartamento social, além da criação de novas representações paisagísticas, chamadas de paisagens urbanas pós-modernas, nos termos de Sharon Zukin. 
do interior, que não possuem parentes em São Paulo e sentem a necessidade de interagir com os vizinhos. Os moradores do condomínio, apesar do contato visual com a favela, estão fisicamente blindados a ponto de não sentirem insegurança dentro de suas casas. Uma visita ao condomínio é suficiente para perceber a dificuldade de acesso, com diversos seguranças na entrada e a necessidade de apresentação de documentos, além da autorização do morador. A moradora cita, como primeiro contato traumático com a favela, o atropelamento de uma criança por um ônibus, ocorrido em 2012, que saiu nos noticiários da tevê e gerou revolta por parte da população da favela, que depredou um ponto de ônibus local.

Ela diz que utiliza a passarela de pedestres que atravessa a Rodovia Raposo Tavares, com ressalvas, mas sem alarmar seus filhos a ponto de deixá-los com medo de sair de casa. Existe um segurança do condomínio, contratado pelos pais, que, em seus horários de folga, acompanha os jovens do condomínio na saída da escola, que fica do outro lado da passarela. A relação custo/benefício encontrada na hora de comprar o apartamento se relativiza no momento do pagamento pelos serviços, muito mais caros em relação ao antigo bairro. Os alugueis caros das lojas dos Shoppings torna os serviços caros.

Em relação ao barulho das festas que ocorrem na favela, principalmente do "pancadão", a moradora relata que a favela é muito silenciosa e que sofria com o barulho de seu antigo local de residência, localizado em área ocupada por bares noturnos. Em relação ao "pancadão", diz que os condôminos sempre evitaram reclamar do barulho, para não causar conflitos entre favela e condomínio, mas ouviu relatos de que os moradores da favela estão cansados dos transtornos causados pelo evento, desde a logística de montagem e retirada do palco até o intenso barulho por toda a noite.

A moradora do condomínio chegou a se arrepender da compra do apartamento quando se deparou com os "pancadões" aos sábados, quando precisava dormir com tampões de ouvidos, mas hoje está adaptada e acredita que o barulho dos bares da Pompeia era pior. Ela acredita que possui uma postura tranquila em relação à favela vizinha, que procura passar para os filhos, ao contrário de alguns de seus vizinhos de condomínio, que trancam seus filhos dentro de casa com receio da violência.

O maior receio da moradora em relação à presença da favela é a possibilidade de invasões na área do Parque e o que mais incomoda em relação aos hábitos dos moradores da favela são as notícias que recebe sobre consumo de drogas por crianças. Como possui contato com moradores da favela, que prestam serviços ao condomínio, ouve relatos de vitimização de crianças e adolescentes pelo consumo de drogas, mas também de uma relação de respeito às famílias que circulam pelos espaços dominados pelo tráfico, por parte dos traficantes. Olhando da janela de seu apartamento, localizado no $28^{\circ}$ andar, diz que a imagem da linha de transmissão da Eletropaulo incomoda mais do que a presença de uma morfologia de favela. 
A moradora se surpreende com a informação de que existiria um córrego na favela. Ela também se surpreende com a baixa utilização dos espaços do Parque pelos moradores da favela, principalmente pelas crianças. Também se surpreende comparando o lazer das crianças do condomínio, que utilizam pipas nos finais de semana, em relação à ausência de visibilidade desse mecanismo de recreação por parte das crianças da favela. Chama atenção que o portão de acesso ao Parque é utilizado como varal de roupas pelos moradores. Diz que o campo de futebol do Parque seria o local mais utilizado, mas por moradores mais velhos. Considera que os moradores da favela são privilegiados pela proximidade de um parque e não entende por que não se apropriam desse equipamento.

Apesar da postura conciliadora da entrevistada indicar uma visão complacente de um morador do condomínio em relação à favela, sabemos que não podemos aplicar essa visão ao restante do condomínio. Relatos de moradores da favela indicam conflitos em relação aos "dois lados", com indicativos de que os moradores do condomínio teriam recebido "garantias" dos vendedores do empreendimento de que a favela seria removida ${ }^{14}$. A própria entrevistada reconhece que grande parte dos moradores do condomínio gostaria que a favela fosse removida e que existem moradores que relatam fatos ocorridos na favela, presenciados de suas sacadas, como consumo de drogas e estupros, nas reuniões de condomínio.

Uma consulta à página de relacionamentos do condomínio na internet, que conta com as programações do cinema e equipamentos de recreação, mostra que os condôminos possuem preocupações práticas em relação ao funcionamento do condomínio, como: falta de vagas no estacionamento (duas por apartamento); reformas gerais, como a substituição da grama do campo de futebol por grama sintética e os pedriscos do jardim por blocos intertravados; além de discussões acaloradas a respeito do número de câmeras de segurança necessárias. 0 atual síndico possui um projeto de instalação de 80 câmeras de segurança e parte dos moradores rebatem a estimativa, dizendo que o condomínio necessitaria apenas de 18 câmeras, além das já existentes. O condomínio conta com uma Comissão de Segurança para tratar dos assuntos correlatos.

\subsection{INTER-RELAÇÕES ENTRE O DENTRO E O FORA}

Importante notar que tanto os moradores do condomínio quanto os da favela têm medo de atravessar a passarela de pedestres da Rodovia. Comparando a relação de segurança e insegurança encontradas dentro e fora, em relação à favela e ao condomínio, para ambas as "comunidades", notamos que a passarela é considerada como local perigoso. Para os moradores do Jardim Jaqueline, a Rua Sebastião Gonçalves, no trecho localizado ao lado do Shopping, também é considerada perigosa, por estar "fora" dos domínios da favela.

14 A moradora que relatou o fato de que seu "patrão", morador do condomínio, teria um contrato em que constava a saída da favela, quando contatada, disse que não trabalhava mais no condomínio e que não teria o contato de seu antigo empregador. 
Dentro das vantagens comparativas apontadas pelos moradores da favela e pela moradora do condomínio, a facilidade de acesso e proximidade de uma rede de serviços é considerada como a maior vantagem para os moradores da favela, enquanto a moradora do condomínio acredita que a localização não é uma vantagem, comparando seu antigo local de moradia, e as maiores vantagens estariam relacionadas à qualidade de vida entre os muros do condomínio e à proporção de áreas verdes e qualidade do ar encontrados no novo endereço. Diferenças de referencial em relação ao mesmo contexto urbano são esperadas para realidades sociais tão divergentes. Enquanto os moradores do Jardim Jaqueline se contentam com as pequenas conquistas alcançadas ao longo nos anos, relativas à infraestrutura instalada, e comparam suas realidades atuais a uma realidade consideravelmente pior, a antiga moradora da Pompeia possui referenciais ligados a seus critérios de qualidade de vida, que incluem qualidade do ar, poluição sonora e espaços verdes. 0 principal ponto que une as preocupações de ambos os lados do muro diz respeito às crianças. É muito significativa a preocupação das mães com à qualidade de vida de seus filhos, em todos os contextos pesquisados. Enquanto as mães da favela estão preocupadas com a creche e o lazer de seus filhos e com os mecanismos de controle social necessários para mantê-los longe das drogas, a mãe do condomínio se preocupa com a sociabilidade e segurança de seus filhos, possivvel dentro de um espaço ideal criado entre muros.

5. CONSIDERAÇõES A RESPEITO DA PESQUISA QUALITATIVA COMO FERRAMENTA DE ESTUDO NA PAISAGEM

Dentre todos os objetivos propostos pela pesquisa qualitativa ou pesquisa-ação, nos moldes da ação proposta por Michel Thiollent, no caso estudado:
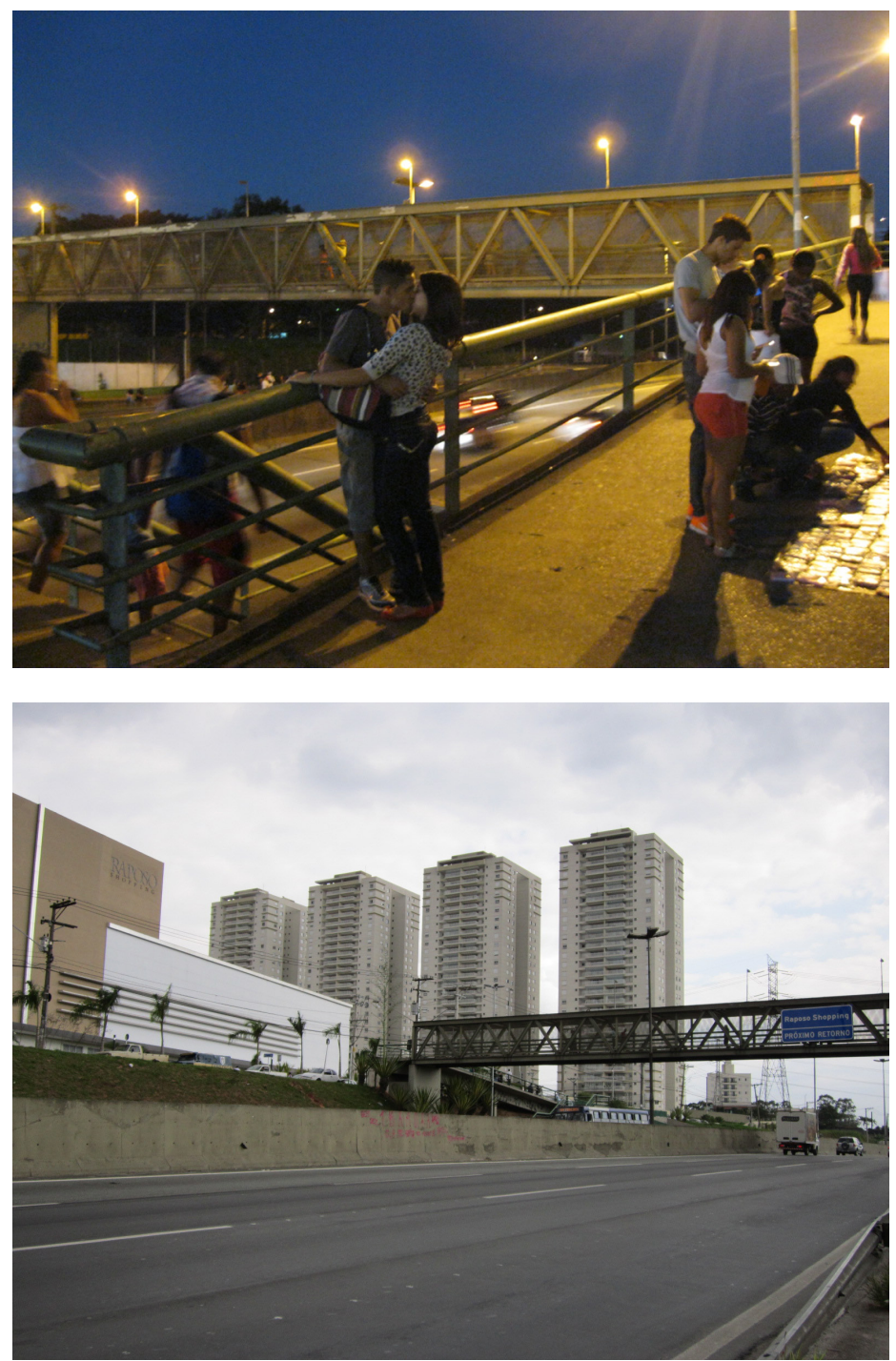

Imagens 29, 30. Fotos da passarela de pedestres que atravessa a Rodovia Raposo Tavares 
[...] os objetivos são voltados para a tomada de consciência dos agentes implicados na atividade investigada. Nesse caso, não se trata apenas de resolver um problema imediato e sim desenvolver a consciência da coletividade nos planos político ou cultural a respeito dos problemas importantes que enfrenta, mesmo quando não se veem soluções a curto prazo [...]. 0 objetivo é tornar mais evidente aos olhos dos interessados a natureza e a complexidade dos problemas considerados (THIOLLENT, 2011: 24).

Ao desejável processo de tomada de consciência, no âmbito do grupo local, deve-se somar o processo de produção de conhecimento, no âmbito acadêmico. Não podemos nos esquecer de que o método proposto foi aplicado em uma situação real, onde variáveis como sexo, faixa etária e profissão não foram isoladas e onde os participantes desempenham papel ativo, inseridos em seus locais de residência. Para efeitos metodológicos, vale a distinção entre "grupo focal", base da pesquisa qualitativa, e "grupo intencional", onde o grupo de participantes não está enquadrado pelas variáveis citadas, mas pelo interesse no processo de participação.

Apesar da maior flexibilidade em relação às propostas de uma pesquisa convencional, a pesquisa qualitativa adotou parâmetros que poderiam ser aplicados por qualquer pesquisador. Foram apresentados questionamentos a respeito da percepção, experiência e desejos dos moradores em relação aos seus locais de moradia. Podemos afirmar que os conceitos trabalhados nas oficinas, relativos à percepção, à experiência e aos desejos que permeiam o imaginário dos moradores delimitam suas relações com a favela, dentro dos seguintes parâmetros de análise: a forma como os moradores comunicam dados a respeito do local, em uma relação permeada de preconceitos e generalidades; como eles vivenciam o local, em relações permeadas pelas contingências, mas que também sugerem

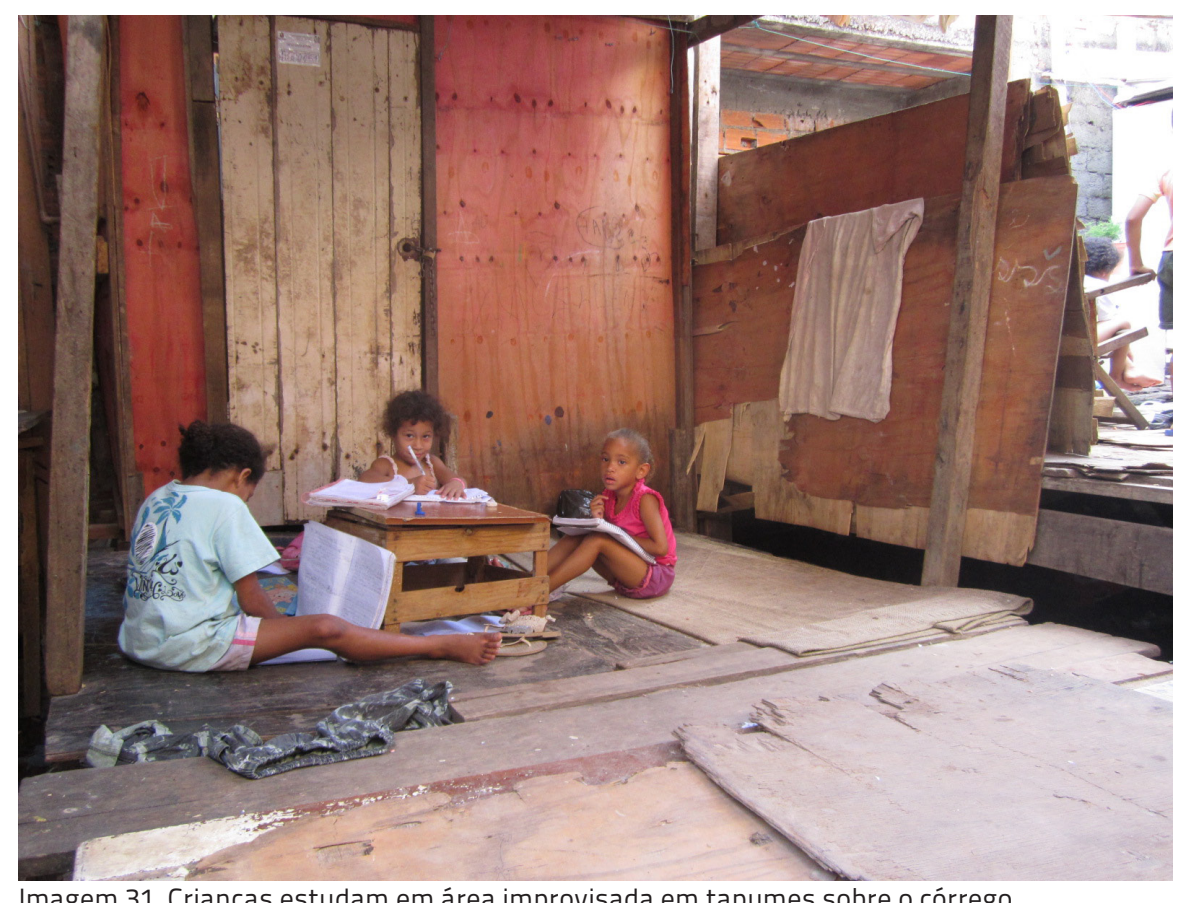

Imagem 31. Crianças estudam em área improvisada em tapumes sobre o córrego 
potencialidades; e seus desejos de cidade, marcados pelas relações utilitárias e mercantilizadas, mas também pela necessidade de ampliações de direitos sobre cidade, que passam pelos espaços coletivos.

Entendemos que os significados que as pessoas dão às suas ações não estão expressos nas primeiras comunicações a respeito do lugar, que podem ser resumidas como um conjunto de representações comuns ao imaginário coletivo a respeito da favela, de forma específica, e sobre a cidade, de forma geral. As formas de vivenciar o lugar e os desejos revelados para além das necessidades básicas são indicativos confiáveis dos significados da paisagem estudada. Se os desejos revelados estão limitados à ordem vigente de consumo na cidade e da cidade, esse fato é um indicativo que deve ser considerado no processo de entendimento do conjunto.

Temos a consciência de que o alcance das intervenções na comunidade é limitado. A principal questão de interesse da comunidade, a regularização fundiária, foi facilmente apreendida pela população, diferentemente das questões intangíveis levantadas pela pesquisa, como apropriação e necessidade de ampliação dos espaços coletivos, que seria equivalente à desejável ação sobre a paisagem. Acreditamos que o desenvolvimento de outros referenciais está associado a mecanismos sociais e culturais que podem ser ativados por meio de expressões artísticas, por exemplo, ou pela atuação de segmentos sociais capazes de estabelecer parcerias com a população local, como a universidade.

Acreditamos que as pequenas contribuições dadas pela pesquisa à população, dentro do intercâmbio de conhecimentos colocado, são extremamente limitadas, mas de grande importância para os participantes que se envolveram no processo de ampliação de referenciais em relação aos seus locais de moradia. Encontramos moradores capazes não somente de assimilar novos conhecimentos, mas de processá-los de acordo com suas necessidades e devolvê-los à pesquisa, não como hipótese comprovada, mas como questões contaminadas de realidade, que devem ser amadurecidas pela universidade.

As limitações inerentes ao processo proposto pela pesquisa qualitativa são claramente colocadas por Michel Thiollent, quando se refere ao seu método de pesquisa-ação:

Devemos deixar bem claro que quando se consegue mudar algo dentro das delimitações de um campo de atuação de algumas dezenas ou centenas de pessoas, tais mudanças são necessariamente limitadas pela permanência do sistema social como um todo, ou da situação geral. 0 sistema social nunca é alterado duravelmente por pequenas modificações ocorrendo na consciência de algumas dezenas ou centenas de pessoas (THIOLLENT, 2011: 51). 
Não temos a pretensão de alterar as estruturas de significação dos habitantes do Jardim Jaqueline, mas acreditamos que, conhecendo as questões a serem enfrentadas e os caminhos possíveis para a melhoria da qualidade de vida na favela, que deve passar necessariamente pela alteração do universo referencial dos moradores, a universidade tem muito a oferecer em relação a esse percurso. Não restam dúvidas de que as "contaminações externas"15 recebidas pelos moradores do Jardim Jaqueline têm contribuído para novas aspirações em relação ao lugar, não mais restritas ao processo de regularização fundiária, e novas ferramentas políticas para negociação junto aos órgãos competentes.

A respeito das ferramentas políticas adquiridas, uma das lideranças relata o processo histórico de "barganhas" eleitorais, que favoreceram pontualmente a favela ao longo do tempo. Ela lembra que o primeiro político que pediu apoio na favela ofereceu o asfaltamento, e os moradores se deram por satisfeitos, dada a situação precária em que se encontravam. O segundo político, de outro partido, disse que não daria para fazer o asfaltamento sem antes implantar o esgoto, o que foi parcialmente realizado. A liderança reconhece: "Antes não sabíamos trabalhar [politicamente], aceitávamos cada oferta sem saber que tínhamos direito a mais". Hoje a liderança se diz mais experiente e preparada para representar os interesses do Jardim Jaqueline e reconhece que, apesar das grandes vitórias alcançadas, dada a situação anterior de extrema precariedade, a solução para a favela passa pela incorporação de todos os direitos que os moradores da cidade formal possuem.

Quando a intervenção está dentro da esfera do subjetivo, Thiollent aponta vários graus de tomada de consciência, que podem variar de uma aproximação do tema tratado sem um caráter crítico a um processo real de conscientização, que, na acepção de Paulo Freire, seria o desenvolvimento crítico da tomada de consciência, que "permite desvelar a realidade, incide ao nível do conhecimento numa postura epistemológica definida e contém até elementos de utopia" (THIOLLENT, 2011: 51).

Acreditamos que exista, em nosso contexto de pesquisa, considerável grau de consciência política, principalmente por parte das lideranças locais. Em diversas falas, uma das lideranças do Jardim Jaqueline se refere à "nossa utopia". Quando usa esses termos como expressão dos espaços, físicos e subjetivos, a serem conquistados para o pleno desenvolvimento de suas demandas sociais, a liderança coloca claramente quais são os ideais que norteiam aquela "comunidade", mas também revela que tais ideais carecem de utopia. Quando a liderança situa reinvindicações que estão contidas dentro de conceitos fabricados pelas classes mais favorecidas, não coloca um ideal de real mudança de paradigmas, a ser construído coletivamente, e apropriado pela dimensão do imaginário, mas ideais de conquistas de igualdade de meios em relação a um contexto social e urbano precário, que deveria ser questionado em sua totalidade. Não se trata de uma crítica em relação à liderança,
15 Cito como contribuições externas à presente pesquisa o processo de regularização fundiária, que contribuiu com importantes subsídios técnicos e jurídicos para o universo referencial dos moradores, e o trabalho desenvolvido pelos alunos de graduação da FAU-USP, dentro da disciplina "Desenho Urbano e projeto dos espaços da Cidade (AUP 274)", que aventaram propostas de urbanização para a favela. Pode-se dizer que o trabaIho desenvolvido pelos alunos de graduação da FAU foi um dos desdobramentos do projeto de regularização fundiária, já que a disciplina contou com monitoria de uma das arquitetas que compôs a equipe da empresa que executou os trabalhos técnicos para o projeto. 
mas principalmente em relação ao seu contexto referencial, que não proporciona aberturas à conquista de novas subjetividades. Como ela mesma diz: é a sua realidade.

Quanto à expressiva participação das lideranças comunitárias no universo da pesquisa, é importante, dentro da pesquisa qualitativa, considerar o peso das opiniões de representantes expressivos dos grupos pesquisados, que é dado pela relevância política dada em determinada conjuntura:

[...] levar em conta a representatividade sociopolítica de grupos ou de opiniões que são minoritários em termos numéricos, mas expressivos de uma situação em termos ideológicos e políticos. Representatividade expressiva pressupõe critérios de avaliação política no seio da conjuntura. A importância social de grupos 'mais avançados' é maior do que seu peso numérico no conjunto da população [...]. Os critérios numéricos podem fazer desaparecer as minorias (THIOLLENT, 2011: 72-73).

Nesse sentido, as contribuições trazidas pelas lideranças não dizem respeito somente às demandas das maiorias em relação a equipamentos e necessidades básicas diárias, mas às estratégias adotadas para as conquistas desses ganhos e para a sobrevivência de uma comunidade instalada em um local em processo de valorização imobiliária. As relações políticas estabelecidas dentro e fora da favela não são perceptíveis por meio da opinião das maiorias, que não percebem as articulações necessárias que viabilizaram o asfalto da sua rua, a linha de ônibus que passa perto dela ou as pequenas melhorias diárias que podem parecer simples iniciativas do poder público.

Quanto ao compromisso do pesquisador e responsabilidades em relação a um contexto social existente, a proposta da pesquisa-ação nos dá pistas a respeito dos limites relacionados ao contexto específico pesquisado:

[...] as propostas de pesquisa-ação sempre apresentam algum aspecto político quanto ao tipo de comprometimento dos pesquisadores com a ação de grupos sociais, dentro de uma situação em transformação. [...] A ação ocorre somente se for do interesse dos grupos e concretamente elaborada e praticada por eles. 0 papel dos pesquisadores é modesto: apenas acompanhar, estimular, catalisar certos aspectos da mudança decidida pelos grupos interessados (THIOLLENT, 2011: 126). 
Quanto às intenções do pesquisador, os objetivos da pesquisa foram claramente colocados, principalmente em relação à socialização ou construção coletiva do conhecimento, com suas dimensões técnicas e sensíveis implícitas, como forma de ampliação de um repertório em permanente desenvolvimento. Felizmente, o processo de transformações junto aos moradores do Jardim Jaqueline está ativado, aguardando novas contribuições que possam manter a dinâmica em curso. 


\section{CAPÍTULO 3. CONTRUÇÕES POSSIVEIS DE UMA PAISAGEM EM MEIO AO URBA- NO PRECÁRIO}

Podemos afirmar que os conceitos trabalhados nas oficinas, relativos à percepção, à experiência e aos desejos que permeiam o imaginário dos moradores, delimitam suas relações com a favela, revelando: as formas com que são colocadas suas representações sobre a paisagem, em uma relação carregada de preconceitos e generalidades pertencentes a uma dimensão prática da vida; como a paisagem é vivenciada, em relações permeadas pelas contingências cotidianas; e principalmente como tais vivências sugerem potencialidades.

Se os seus desejos de cidade se revelaram marcados pelas relações utilitárias e mercantilizadas, temos como objetivo da pesquisa buscar matrizes explicativas que situem tais demandas em um contexto social ampliado, no qual os moradores locais não devem ser colocados como únicos responsáveis por sua tragédia, assim como os moradores dos condomínios fechados de alto padrão não são responsáveis, com seus íntimos desejos de distinção social, pelo processo de enclausuramento e apartamento social verificado nas grandes cidades.

Ao mesmo tempo em que a pesquisa deve explicar o fenômeno encontrado nos trabalhos de campo, também pode sugerir caminhos possíveis para a efetivação de outras relações com a paisagem, buscando - assim como os moradores o fazem em seus cotidianos precários - ações possíveis dentro em meio a adversidade.

As limitações encontradas nas oficinas em relação ao universo referencial dos moradores revelam certas particularidades relacionadas à história de precariedade e pequenas conquistas locais, muito significativas para os moradores. 0 cenário precário deu lugar às sucessivas conquistas alcançadas em períodos eleitorais, derivadas do poder investido periodicamente nestes cidadãos por meio do voto.

Com o universo empírico em mente, podemos entender essa paisagem - e paisagens correlatas de seu entorno imediato - de acordo com importantes representações desenvolvidas nas áreas de ciências sociais, e dentro dela, da Antropologia, com a utilização dos seguintes conceitos: os enclaves fortificados, ou processos de enclausuramento e de apartamento social, propostos pela socióloga Teresa Caldeira; e a identificação de características de uma paisagem urbana pós-moderna, de acordo com modelo proposto pela socióloga Sharon Zukin. Em se tratando de projetos existentes no entorno imediato e possíveis projetos de intervenção para a favela, devemos trabalhar os conceitos de valorização, enobrecimento e espaços liminares, propostos pela autora. 
Em relação aos "agenciamentos da vida cotidiana" constatados nas oficinas, devemos fazer uma breve incursão em relação às aproximações entre o ilegal, o irregular e o ilícito, expressas no urbano, de acordo com trabalhos desenvolvidos por Vera da Silva Telles e Daniel Hirata. Entendendo o extenso campo de investigação que o tema suscita, ficaremos somente no campo dos agenciamentos cotidianos do "mundo da irregularidade", para não perder o foco da pesquisa.

A partir dos referenciais teóricos apresentados, procuraremos entender porque a real mudança dessa paisagem deve passar por mudanças anteriores não somente em relação às percepções da população local, mas também em relação à percepção de gestores públicos, grande parte da academia e de um estigma que perdura até nossos dias em relação aos habitantes da favela.

Colocar um problema de acordo com um viés específico implica na sugestão de possíveis saídas para o nosso impasse. Não pretendemos terminar a investigação em meio ao impasse colocado, mas dentro de um caminho possível de redefinição em relação a um campo de forças a princípio insolúvel, onde o nosso papel, enquanto arquitetos e urbanistas, é entender onde se encontra nossa atuação em meio às disputas colocadas. Caminhando em direção às possibilidades de emancipação em relação a um cenário redutor da dimensão humana e coletiva da vida, vamos tatear o campo de investigação proposto por Boaventura Sousa Santos, dentro da relação entre subjetividade, cidadania e emancipação, passando pela contribuição sempre fundamental de nossa filósofa Marilena Chauí.

Acreditamos que as particularidades locais, ou representações colocadas pelos moradores, ao mesmo tempo em que fazem parte de representações dominantes em nossa sociedade, que revelam um contexto com poucas perspectivas e restringem nosso campo de atuação, devem ser constantemente colocados e problematizados como forma de se avançar no campo das disputas pela cidade, por meio de ampliações de direitos sociais sobre a cidade, que passam necessariamente pelos espaços coletivos.

O estudo de uma favela específica, inserida em um eixo de desenvolvimento imobiliário, se mostra relevante em meio às paisagens existentes e possiveis, como forma de se contrapor a uma concepção ideológica corrente de que as favelas somente ganhariam uma paisagem quando submetidas a projetos de urbanização, pré-formatados e aplicáveis em série, como grande parte dos projetos habitacionais conhecidos. O estudo de uma suposta "não paisagem" - desprovida de áreas livres ou locais onde seus moradores possam se exprimir e cujas histórias supostamente poderiam ser resumidas nas estatísticas de pobreza e exclusão social que acompanham o crescimento das grandes metrópoles - revela um universo desconhecido a ser explorado. Ao longo de nosso percurso pudemos perceber que os dados oficiais disponiveis a respeito do 
Jardim Jaqueline, mesmo em relação ao recente levantamento técnico executado para o processo de regularização fundiária, não expressam a real dimensão da vida envolvida no cotidiano de seus moradores, que surgiu, ainda que timidamente, nas oficinas realizadas no âmbito de nossa pesquisa.

Partindo de um contexto situado que levantou questões a serem investigadas e não de teorias prévias do conhecimento sobre o urbano ou sobre a paisagem, que foram esboçadas no primeiro capítulo, nossa linha de desenvolvimento teórico seguirá temas pertinentes às questões colocadas pelas oficinas. Sendo a paisagem nossa categoria principal de investigação, traremos uma breve conceituação sobre o tema, com objetivo de afastar nosso objeto de um lugar comum, que associa paisagem a uma representação paisagística'. Importante frisar que nossa paisagem faz parte de um universo referencial situado socialmente e culturalmente. As vertentes explicativas utilizadas, carregadas com o peso da cultura, indicam as possibilidades de desvelamento de novas paisagens, não relacionadas à "valorização" derivada da criação de novos espaços, mas ao reconhecimento de seu substrato social.

\section{O SURGIMENTO DA IDEIA DE PAISAGEM E SEUS SIGNIFICADOS}

Do universo delimitado pela visão ao universo que a experiência sensivel alcança, a ideia de paisagem possui um percurso histórico que a insere em um conjunto de valores culturalmente construídos. Da acepção comum ligada às belezas naturais, derivada de uma construção do século XVIII, ao entendimento contemporâneo de que a paisagem é história, contexto e ação de sujeitos nela situados, temos um longo processo de entendimento a respeito de sua natureza polissêmica e da formação de um referencial de paisagem que atenda às necessidades de nossa época. Temos como desafio aqui colocado o desenvolvimento de um conceito, hoje reconhecido pela forma com que é empregado no campo do paisagismo, como ferramenta de entendimento de outro cenário, caracterizado pela exclusão socioterritorial, onde a paisagem é tida como preocupação menor, frente às contingências cotidianas ligadas à ordem econômica vigente.

Pode-se considerar que a construção da ideia de paisagem começa a se delinear com o surgimento da cidade moderna europeia, que marca a transição entre uma concepção de mundo em que homem e natureza faziam parte de uma unidade em harmonia, e a modernidade, com seu embate insolúvel em relação a uma natureza que se contrapõe à ação humana sobre o meio e que deve ser dominada. Por meio de mediações estéticas, a ideia de paisagem passa a contar com representações artísticas que configuraram a moderna ideia de paisagem, ou seja, o interesse da natureza enquanto paisagem surge da construção estética de uma natureza separada da objetivação científica das ciências naturais. "O céu e a terra da
1 Não estamos aqui desvalorizando a dimensão referencial e simbólica das expressões paisagísticas. Pelo contrário, acreditamos que o paisagismo seria a expressão última de um processo de ativação local, onde as relações de reconhecimento e pertencimento em relação à paisagem podem despertar as representações paisagísticas na paisagem. 
existência humana, não mais acedendo ao saber e à expressão na ciência como acediam outrora no conceito filosófico antigo, serão traduzidos esteticamente pela literatura e pela arte sob a forma de paisagens" (RITTER, 1997: 19).

Essa separação entre natureza e paisagem trouxe consequências ainda incontornáveis em relação ao viver nas cidades. A paisagem inscrita em nosso imaginário social, local de refúgio, localizada preferencialmente fora das grandes cidades, traz a imagem da tragédia de nossos tempos. A tragédia de buscar a tal paisagem em locais cada vez mais distantes de nossas existências, como se o ambiente da vida não comportasse o ambiente do bem viver. "[A] figura da megalópole, a metrópole gigante da cidade industrial que absorve com seus tentáculos a cidade histórica e a paisagem cultural, alerta-nos para o empobrecimento da dimensão temporal da existência e, no limite, para a extinção total da vida" (SERRÃO, 2012: 25).

Uma necessidade dos tempos modernos interpretou a natureza em sua totalidade, como paisagem, 'não mais por meio do conceito e sim no sentimento estético, não mais pela ciência e sim pela literatura e pela arte, não mais na transcendência do conceito e sim no transcender de uma fruição que se transporta na natureza" (RITTER: 1997: 11). Tal paisagem só se expressa para o homem que se volta a ela para fruir livremente do seu espetáculo e para estar ele próprio no seio da natureza, sem visar finalidades práticas. Dessa forma, tudo que chamamos genericamente de paisagem, como as montanhas, vales, rios "só se tornam paisagem para o homem que se volta e eles para fruir livremente do seu espetáculo e para estar ele próprio no seio da natureza, sem visar finalidades práticas" (RITTER, 1997: 12). Ou, nas palavras de Georg Simmel (1988), para que haja paisagem, a consciência deve apreender, além dos elementos, um novo conjunto, uma nova unidade, não ligados aos significados particulares de cada elemento, nem compostos mecanicamente de sua soma. A consciência da paisagem pressupõe que esse conjunto singular apreendido pelo campo de visão cative nosso espírito. Tal movimento proposto por Simmel apresenta a dialética inerente ao conceito de paisagem, que não se confunde com a natureza, mas a utiliza em sua totalidade para extrair o "conjunto singular apreendido pelo campo de visão".

Após essa traumática separação entre natureza e paisagem, representações artísticas operaram mediações estéticas que firmaram uma ideia de paisagem que passou a fazer parte de nosso imaginário paisagístico. Se "a noção de paisagem e sua realidade percebida são justamente uma invenção, um objeto cultural patenteado, cuja função própria é reassegurar permanentemente os quadros da percepção do tempo e do espaço" (CAUQUELIN, 2007: 12), como se dão essas tensões a ideia de paisagem e suas representações no universo contemporâneo?

Se a relação entre paisagem e representações ditadas por um determinado período histórico se mostra naturalizada dentro de uma concepção estigmatizada da paisagem, que se perpetua até nossos dias, nosso tempo histórico mostra 
novos significados atribuídos ao tema, uma ampliação significativa dos meios de representação e a necessidade de novos entendimentos em relação a um campo conceitual ampliado.

\subsection{CARACTERIZAÇÃO DAS PAISAGENS CONTEMPORÂNEAS}

Em um contexto contemporâneo, no qual o mundo é apreendido por fragmentos, a paisagem é expressão dessa fragmentação, dada por imagens idealizadas e desvinculadas do corpo social ao qual deveria estar relacionada. Além das imagens de paisagens fossilizadas por meio das políticas de preservação patrimoniais no urbano, que fazem parte de um passado sem memória, idealizado como imagem, grande parte do pensamento contemporâneo sobre a paisagem é rapidamente associado a uma natureza preferencialmente intocável. A paisagem assim idealizada, desvinculada das interações sociais que a ativam e considerada como tema pouco relevante dentro das questões que conduzem nossa existência prática, como a política e a economia, fica restrita ao universo ideológico da sustentabilidade. Dessa forma, as reflexões e intervenções urbanas consideram as necessidades sociais de forma fragmentada, como as demandas por infraestrutura, habitação, transportes e serviços, relegando a paisagem à condição de verniz dispensável perante as grandes questões a serem enfrentadas em um contexto de segregação socioespacial, em que a paisagem visual é, ironicamente, utilizada como instrumento desse processo de segregação.

Mesmo quando a paisagem se descola da ideologia ambiental em voga, ela é associada a símbolos do progresso contemporâneo, como pontes, conjuntos empresariais, grandes avenidas e outras tantas imagens que sugerem que os símbolos eleitos do progresso econômicos seriam as novas paisagens "eleitas" de nosso tempo.

Diante de um campo conceitual tão complexo, de difícil assimilação mesmo por parte de pesquisadores da universidade, como inserir tal tema em nosso contexto de investigação sem cair na armadilha de inserir um conceito que possui unidade, de acordo com imagens ou fragmentos compreensíveis, mas que não dariam a dimensão real do conceito - somente visões parcelares que cairiam no mesmo senso comum, da representação paisagística?

Para manter a coerência em relação a um conceito de investigação que revela grande complexidade, principalmente em relação a um senso comum vinculado ao termo paisagem, optamos por investigar o conceito sem nomeá-lo, ou seja, buscar referenciais locais a respeito da percepção e relações com a paisagem sem se referir nominalmente a ela. Sem muitas certezas em relação ao partido tomado, fomos às oficinas - com uma postura mais receptiva do que assertiva - e recebemos as contribuições que possibilitaram o nosso caminho conceitual, dentro de um campo semântico tão vasto que é o da paisagem. 
Quando os moradores se referiram: "ao meu pedaço"; aos espaços coletivos perdidos pelas disputas individuais por espaço; às fronteiras simbólicas que dividem o dentro e o fora; às relações de vivência coletivas que são perdidas pelo poder econômico, que se expressa localmente e se expande em suas relações com a cidade; aos ideais em relação à cidade, que revelam particularidades, mas que indicam fortes relações com referenciais partilhados por todas as classes sociais; ou às tímidas necessidades, que não conseguem referenciais expandidos em relação aos reais direitos que possuem; estão revelando qual a dimensão da paisagem que deve ser problematizada em nossa investigação.

\section{MAPEANDO CULTURA E PODER ${ }^{2}$}

Para mapear os símbolos de nossa cultura contemporânea associados à paisagem, precisamos entender como e com qual finalidade se dão as construções contemporâneas em torno da ideia de paisagem.

Sharon Zukin relaciona o processo social de construção das paisagens pós-modernas à fragmentação econômica das antigas solidariedades urbanas e posterior reintegração, matizada pelas novas formas de apropriação cultural. Os investidores imobiliários, nesse contexto, invertem a narrativa da cidade moderna, tornando-a um nexo fictício, uma imagem que uma larga faixa da população pode comprar, um panorama onírico de consumo visual (ZUKIN, 2000: 81). Neste contexto, a apropriação cultural é utilizada como estratégia de aumento do valor econômico.

O conceito de espaços liminares está ligado aos espaços de transição criados nas cidades nesse contexto, que caracterizam a sua paisagem. Fazem parte do esforço pós-moderno em falsear e fazer a mediação entre natureza e artefato, uso público e valor privado, mercado global e lugar específico, "misturando funções e histórias, um espaço liminar situa o usuário 'a meio caminho' entre instituições". O espaço liminar não é permeável à construção de identidades espaciais, pelo contrário, "as mesmas características que tornam os espaços liminares tão atraentes, tão competitivos em uma economia de mercado, representam também o desgaste da diferenciação local" (ZUKIN, 2000: 82). Apesar de a autora estar se referindo a ícones ligados ao consumo e entretenimento, como no caso da Disney World, também podemos associar a ideia de espaços liminares às chamadas "âncoras" de requalificação urbana, presentes nos diversos projetos de requalificação urbana de centros históricos, ou aos diversos shoppings centers espalhados pelas periferias, que se configuram como referenciais urbanos.

Podemos identificar alguns desses espaços ao longo da Rodovia Raposo Tavares, em locais antes caracterizados pela existência de indústrias, olarias e loteamentos residenciais horizontais de média e baixa renda. Quando a antiga distância se transforma em proximidade, em relação a uma cidade que depende cada vez mais do transporte individual e que

2 Subtítulo do artigo de Sharon Zukin (2000). 
transforma suas antigas rodovias em avenidas urbanas, a paisagem é tomada por padrões de ocupação indiferentes em relação ao lugar e reprodutiveis por toda a cidade, que são os condomínios fechados e os Shoppings Centers. Em relação à nossa favela, temos os dois modelos, que - devidamente apartados do tecido circundante - tentam criar, dentro de seus domínios, o coletivo, a natureza e o exclusivo.

O desenvolvimento dos espaços liminares estaria estruturado sobre as seguintes bases: a crescente globalização do investimento e da produção; a abstração contínua do valor cultural em relação ao trabalho material; e o processo de significação social baseado no consumo. Nesses termos, alterando nossa experiência de vida e modelando nosso cotidiano, "[...] uma paisagem urbana pós-moderna não apenas mapeia cultura e poder, mapeia também a oposição entre mercado - as forças econômicas que desvinculam as pessoas de instituições sociais estabelecidas, e lugar - as formas espaciais que as ancoram no mundo social, proporcionando a base para uma identidade estável" (ZUKIN, 2000: 83).

A transformação da paisagem expressa a apropriação cultural de nosso tempo, sendo que o processo de mapeamento da paisagem se mostra importante para entendermos as mudanças como processo estrutural, que tem ressonância tanto no ambiente construído como em sua representação coletiva, relacionando a maneira como o capital se inscreve nas formas espaciais. Não precisamos de um exemplo limite, como o da Disney World, para chegar aos mesmos referenciais da autora. Nosso referencial urbano em São Paulo, de cenários resultantes do deslocamento das elites para além do centro expendido, nos dá importantes características dessa expressão do poder econômico no território. Nossos exemplos específicos, o condomínio fechado, com seu rol de atividades privativas dotadas de toda a segurança e privacidade, e o centro de compras, abastecido de todas as facilidades, mercadorias e lazer que os moradores do entorno necessitam, delimitam uma unidade de paisagem característica das novas frentes de apropriação do mercado imobiliário.

Tal paisagem, aparentemente artificial aos olhos de quem ainda vive uma relação mais próxima com a cidade, dentro de sua diversidade social, é naturalizada por seus usuários, a ponto de acreditarem que essa nova realidade urbana é a melhor alternativa de vida nas grandes cidades. De fato, frente às crescentes necessidades da vida contemporânea, viver em espaços fechados que reúnem todos, ou quase todos, os serviços necessários ao dia a dia - como aulas de hidroginástica, yoga, recreação infantil, salão de beleza e aulas de línguas para as crianças - parece a solução ideal para uma classe média urbana que sofre com os problemas de mobilidade e violência nos grandes centros urbanos. O desenvolvimento do capital cria primeiramente as necessidades e os valores de pertencimento em relação a determinada classe, como todas as atividades possíveis após o expediente de trabalho, ou que se confundem com o trabalho, como a preocupação com a
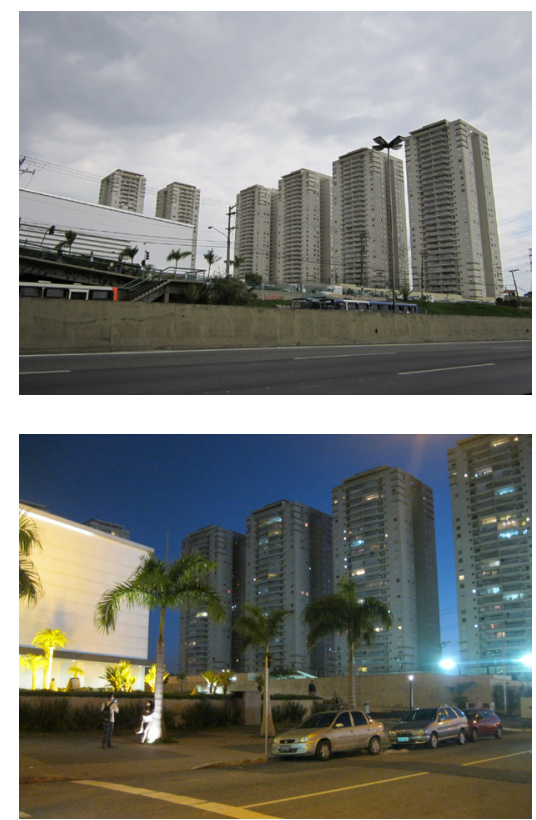

Imagens 1, 2. Espaços liminares 
aparência física ou o capital cultural necessário ao relacionamento dentro do ambiente de trabalho. Concomitantemente, o capital imobiliário cria a solução capaz de suprir todas as necessidades cotidianas, fabricando cenários urbanos facilmente reconhecíveis como os novos enclaves da classe média.

Considerando o paradoxo expresso visualmente nas paisagens urbanas, que põe lado a lado os referenciais simbólicos das classes dominantes e as formas de habitação da população excluída desse "ideal de cidade", questionamos se seriam, de fato, essas criações contemporâneas a expressão da paisagem de nosso tempo. Esses enclaves construídos que moldam o cotidiano de futuros moradores podem ser mais facilmente reconhecidos como expressão da paisagem contemporânea das grandes cidades, mas não seriam as favelas, ocupações espontâneas decorrentes da precariedade que caracteriza os modos de vida da maioria da população, a expressão definitiva de nossa paisagem contemporânea? Não se trata somente de uma disputa por espaço, mas de uma disputa simbólica.

Sharon Zukin reconhece na transformação atual da paisagem, cooptada pelo poder econômico, o maior exemplo de apropriação cultural de nosso tempo. Relacionando formas espaciais e práticas culturais (paisagem) estamos falando em processos estruturais que afetam não somente o ambiente construído, mas também as representações coletivas, dentro de um conjunto de paisagens urbanas arquetípicas (ZUKIN, 2000: 83).

Assim como diz Marilena Chauí, a respeito das construções ideológicas que são ditadas pelas classes dominantes, as representações coletivas em torno da paisagem urbana são ditadas pelo 'gosto" das classes dominantes. As ideias das classes dominantes são ideias dominantes para a sociedade como um todo, de modo que a classe que domina no plano material (econômico, social e político) também domina no plano espiritual, das ideias (CHAUí, 2006: 85). Dessa forma, não é difícil embutir no imaginário das classes dominadas que o modelo de cidade imposto pelo capital imobiliário é o modelo desejado para todos. Vale a pena citar uma passagem emblemática do livro de Mariana Fix, Parceiros da Exclusão, onde ex-moradora do Jardim Edith relata: "Eu saí em novembro. O povo falava: 'Ah, que vergonha, o luxo encostado no lixo'. Mas era mesmo, isso aí eu não vou tirar a razão de ninguém não. Ali estava precisando tirar mesmo [...]. Está bonito. Se você passa lá você vai ver que coisa mais linda está lá, limpinho" (FIX, 2011). Trata-se de exemplo cabal de como as ideologias se infiltram no imaginário e nos discursos das classes oprimidas, que mal acreditam que possuem o direito a um local "bonito". Como se eles fossem a causa da "feiura" de determinados espaços, como acreditam muitos segmentos de nossas classes dominantes. Fica claro que a captura dos valores simbólicos de uma sociedade é a conquista máxima do poder das "instituições históricas dominantes".
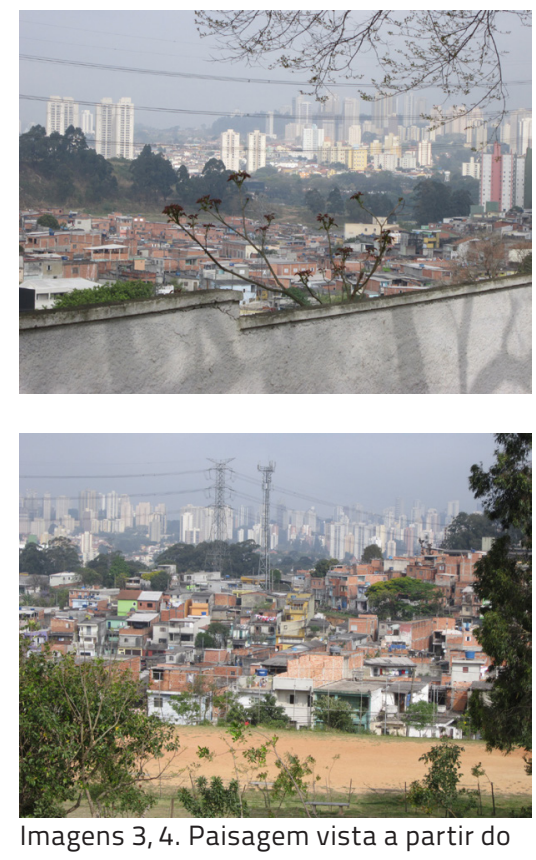
Parque 
Sharon Zukin coloca a paisagem como socialmente construída e ordenada em torno de uma paisagem política, edificada em volta das instituições históricas dominantes - a igreja, o latifúndio, a fábrica etc. - e de paisagens habitadas, espontâneas, autoconstruídas, decorrente das necessidades de pessoas comuns ao longo do tempo. "Mesmo que a paisagem política e a paisagem habitada ${ }^{3}$ desenvolvam-se lado a lado, os criadores da paisagem política desfrutam de um poder maior, seus recursos fornecem a estabilidade que a paisagem habitada requer" (ZUKIN, 2000: 84).

Nos espaços institucionais, a constatação da autora é crucial para o nosso entendimento de paisagem, na medida em que vincula diretamente paisagem a uma relação de poder. A paisagem política e a paisagem habitada - que podemos reconhecer em nosso contexto como a paisagem da cidade formal, em contraponto à paisagem da cidade real - nos dão referenciais importantes a respeito do jogo de poder em torno do ambiente construído. No caso do entorno do Jardim Jaqueline, apesar da paisagem habitada - ou informal - fazer parte da estrutura cotidiana do entorno, com suas relações empregatícias e de consumo, a ausência de "estabilidade" dada pela informalidade, torna evidente o poder de seus vizinhos ricos, que não contam com uma conjuntura jurídica adequada, já que violam diversos dispositivos de controle urbano, mas são vistos como parte de uma paisagem formal, legitimada como tal. Essa desigualdade evidencia relações de opressão, como a construção de muralhas por parte do Shopping em locais que não fazem parte de seus domínios, lançamento de esgoto sobre a favela, tamponamento das nascentes antes utilizadas pelos moradores da favela. Além da opressão consentida em relação à favela - possível pela relação de desigualdades legal e econômica estabelecidas -, a lista de irregularidades cometidas pelos ocupantes da paisagem política inclui construções irregulares sobre Áreas de Preservação Permanentes, ocupação de áreas verdes públicas, construção de muros em terreno alheio e outros conjuntos de irregularidades relatadas em notícias veiculadas pela imprensa, que tratam da investigação do Ministério Público de São Paulo sobre processo de aprovação de obras e alvarás de funcionamento de centros de compras em São Paulo ${ }^{4}$. Classes sociais que detêm o poder econômico também detêm o poder político e jurídico, conseguindo concessões e privilégios, enquanto a população mais fragilizada socialmente, detentora de direitos presumidos, não consegue efetivá-los.

A paisagem dá forma material a uma assimetria entre o poder econômico e o cultural. Essa assimetria de poder modela o sentido dual da paisagem. [...] [0] termo 'paisagem' diz respeito à chancela especial de instituições dominantes na topografia natural e no terreno social, bem como a todo o conjunto do ambiente construído, gerenciado ou reformulado de algum modo (ZUKIN, 1996: 84).
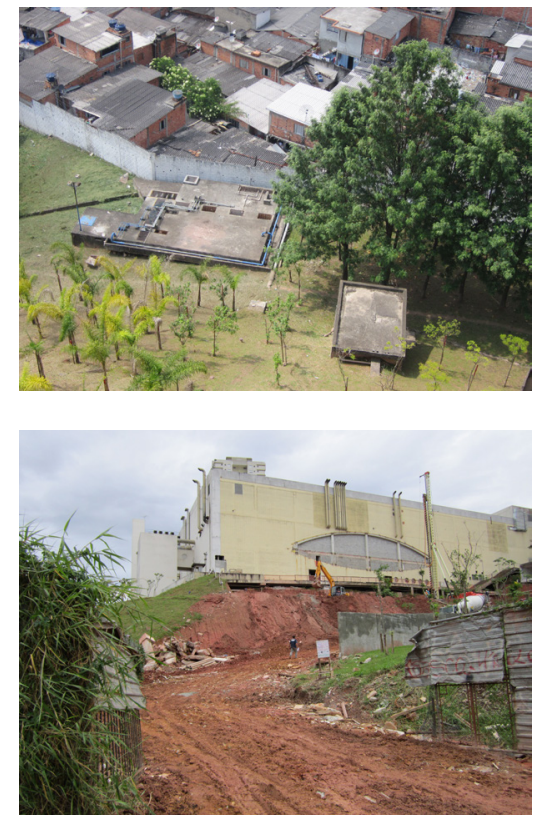

Imagens 5, 6. Nascentes tamponadas

3 Divisão proposta pelo geógrafo da paisagem J.B. Jackson (1984).

4 Segundo matéria do jornal O Estado de S. Paulo, Shopping, controlado pela multinacional Brookfield, juntamente com outros centros de compras de São Paulo, é investigado por indícios de pagamento de propina a Hussain Aref Saab, ex-diretor da Secretaria Municipal de Habitação, com o objetivo de aprovar obras irregulares. BRANCATELLI; ZANCHETTA, 2012. 
Desse modo, podemos enquadrar grande parte dos projetos de construção e reconstrução do espaço urbano em projetos de paisagem, que consideram tantos outros fatores antes de considerar como partido a própria paisagem existente. As soluções adotadas são justificadas por meio de planilhas de custo, facilidades de execução decorrentes de um know how consolidado, criado e perpetuado pela indústria da construção civil, tudo isso legitimado pelo "hábito" em relação a tais partidos e modus operandi. Esse "hábito" diz respeito ao projeto de paisagem idealizado pelos setores dominantes da sociedade e reproduzido por todas as classes sociais, seja nos grandes projetos urbanos ou nos pequenos detalhes construtivos das ocupações espontâneas.

Essa assimetria apontada pela autora modela o sentido dual da paisagem, em que podemos entender tanto uma relação de oposição entre realidades distintas quanto uma relação simbiótica, na qual as duas realidades fazem parte de um conjunto dinâmico e coerente. Apesar de todas as diferenças que podemos apontar, em um primeiro momento, entre a realidade da favela e dos espaços formais, uma análise mais atenta do cotidiano do entorno denuncia uma relação muito próxima entre esses universos, dada pelos vínculos empregatícios e pelas dinâmicas de consumo. Os moradores da favela trabalham no centro de compras e no condomínio fechado e frequentam os mesmos espaços de consumo que os habitantes da cidade formal.

\subsection{A CAPACIDADE DE DESLOCAMENTO COMO INSTRUMENTO DE PODER}

A percepção que os habitantes têm da própria paisagem e das paisagens possíveis derivadas de suas ações é um importante ingrediente para a formação do quadro da paisagem contemporânea. "O ato de tomar uma perspectiva tem consequências para a percepção cognitiva e para a apropriação material" (ZUKIN, 1996: 84). Desse modo, as múltiplas perspectivas do capital, vinculadas a uma classe dominante com poder de mobilidade, com repertório imagético ampliado em relação às classes que permanecem restritas aos seus locais de moradia, dominam nosso imaginário em relação ao que a autora chama de "paisagens contemporâneas".

Nesse sentido, podemos identificar uma contradição em relação ao repertório ampliado das classes dirigentes, dado pela capacidade de mobilidade e acesso a um universo referencial expandido: a ausência de repertório das classes menos favorecidas, presas ao lugar pela impossibilidade da mobilidade geográfica, pode ser considerada uma desvantagem no jogo de poder pelos referenciais imagéticos dominantes, mas pode ser vista como possibilidade de vínculo e valorização do lugar específico. Lembrando que, mesmo essa restrição de experiências cognitivas dada pela limitação geográfica é 
relativizada pela ampliação do consumo visual de "lugares", dado pelos meios de comunicação de massa. Os consumidores de novelas e propagandas de destinos turísticos, por exemplo, são convencidos de que conhecem tais locais, por meio das imagens consumidas.

A defesa de um olhar mais situado, desaparelhado das ideologias das classes dominantes, que trazem o seu ideal de moradia, não representa a aceitação de uma condição desigual de mobilidade entre classes no urbano. Pelo contrário, o entendimento de que a possibilidade de grande mobilidade por parte das classes de alta renda gerou um modelo não desejável de apropriação do território deve ser questionado. Esse modelo se relaciona à proximidade dada pelo transporte individual, com seus tempos e trajetos, e deve ser combatido, em nome da qualidade de vida nas grandes cidades.

Outra contradição encontrada a partir da matriz da mobilidade desigual entre as classes é o fato de que, mesmo tendo oportunidades de deslocamento e de apropriações culturais diversas, as classes dominantes nacionais incorporam pastiches de culturas consideradas superiores e criam universos referenciais próprios, diretamente ligados a interesses imobiliários. Dessa forma, estilos de vida invejados pelas elites nacionais - como a apropriação das ruas nas cidades europeias - não são incorporados à realidade nacional. Ao contrário, criam um estilo de vida médio próprio de nossas grandes cidades, onde a paisagem é resultante não de repertórios apropriados por uma elite "viajada", mas pela formatação de um mercado imobiliário ávido por grandes lucros, onde interessa o aproveitamento máximo do terreno, a localização privilegiada e os acessórios de "sociabilidade" que cabem dentro de um mesmo empreendimento. 0 saldo final fica barato para o empreendedor, que necessita somente de salas, sem projetos específicos, vinculadas a qualquer função que possa garantir valorização ao empreendimento. Se paga mais ao profissional de marketing que venderá tais "necessidades" do que ao profissional de arquitetura, a quem cabe idealizar "somente" os espaços físicos.

O que se critica aqui é a espécie de poder simbólico que nossas elites econômicas estão imprimindo na paisagem, imposto por forças de um mercado que não possui qualquer compromisso com a cidade, tampouco com a qualidade de vida ligada aos espaços coletivos. Vale citar um comentário de uma compradora de um desses novos empreendimentos urbanos de São Paulo, que afirma: "O acabamento é ótimo e a localização também. Mas prefiro continuar no meu apartamento de 89 metros quadrados", diz a investidora, que comprou dois apartamentos "compactos de alto padrão", que considera pequenos demais para morar, mas bons para investir ${ }^{5}$. David Harvey nos deu os referenciais teóricos necessários para afirmar que a cidade se tornou uma das mercadorias mais lucrativas de nosso tempo, mas constatar a escala de naturalização que essa dimensão do mercado alcançou torna o fato mais alarmante. E como a ideologia opera transmitindo os valores das classes

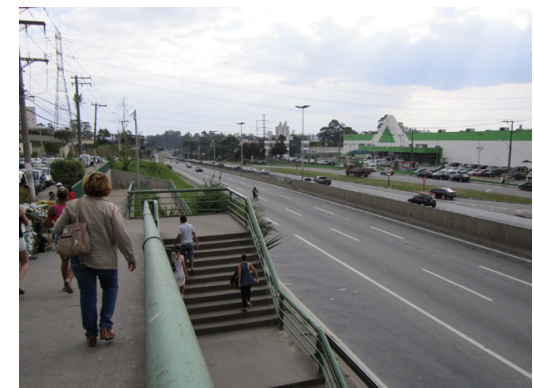

Imagem 7. Rodovia Raposo Tavares 
dirigentes para as classes dominadas, também temos inúmeros exemplos de especulação imobiliária na favela, como no caso de um dos moradores com os quais a pesquisadora teve oportunidade de conversar, habitante da área mais precária da favela, analfabeto, que pretende construir outros andares sobre sua residência para viver de aluguel. Quando questionado sobre a possibilidade de remoção de sua casa, o morador respondeu tranquilamente: "A prefeitura demora para fazer qualquer coisa por aqui. Se eu conseguir o aluguel por cinco anos já estou lucrando". Se o solo urbano se tornou uma mercadoria tão lucrativa, o que será dos espaços coletivos e dos espaços de utilidade ambiental dos grandes centros urbanos, que, a principio, não serviriam ao processo especulativo?

\subsection{FORMAS DE APROPRIAÇÃO DA PAISAGEM: A ESTRATÉGIA DA CULTURA}

Para agregar valor a essa mercadoria (a cidade), o empreendedor imobiliário processa sua paisagem para consumo visual, sendo capaz de transformar antigos referenciais ligados à cultura popular em símbolos culturais, como antigos centros urbanos e bairros populares. Sharon Zukin chama atenção, em relação ao contexto americano, para o processo de incorporação do vernacular, ligado às ocupações populares espontâneas e à paisagem, por meio de um processo de apropriação cultural, no qual "o vernacular é incorporado à paisagem e projetado de volta como uma imagem investida de poder cultural". Com as devidas ressalvas ao nosso contexto particular, podemos identificar tal percurso nos centros históricos das cidades europeias e em muitos projetos de reconversão de centros históricos no Brasil, mas devemos analisar a crítica em relação a esse tipo de apropriação com certo cuidado, já que a preservação do tecido urbano é desejável em contextos históricos e sociais específicos e ações devem ser feitas, principalmente em relação a situações precárias. Vemos que, ao mesmo tempo em que a apropriação cultural/financeira de referências históricas deve ser problematizada, alternativas que visem a melhoria da qualidade de vida da população residente não devem ser abandonadas.

Mesmo com a consciência de estarmos constantemente em posição frágil, pelas estratégias de apropriação urbana do capital via valorização, a ação sobre a paisagem é necessária e a questão colocada por Sharon Zukin em relação ao vernacular americano, comparado ao nosso contexto de ocupação espontânea do espaço, deve ser entendida de acordo com um duplo viés: de possiblidade de apropriação financeira via poder cultural investido e de possibilidade de respeito a tecidos sociais e memórias existentes.

A resposta para a questão do destino dos espaços coletivos e dos espaços de utilidade ambiental caminha nesse sentido: de apropriação financeira via valoração cultural. Os locais ambientalmente protegidos efetivamente preservados
5 Depoimento extraído de matéria sobre o tema. VASQUES, 2013. 
de nossas cidades comumente estão associados à estratégia de localização. A proximidade de um parque valoriza um empreendimento, assim como o "verde" enobrece o local de moradia, mesmo que apartado dos serviços ambientais correlatos. O enobrecimento atribuído ao patrimônio cultural e ambiental faz parte de uma das inovações atribuídas pela sociedade contemporânea à ideia de patrimônio:

[...] reservam-se edifícios e logradouros, parques e rios, lagos e bosques aos quais se atribui a qualidade de semióforos ${ }^{6}$, de maneira a garantir, de um lado, que todo restante possa ser devastado pela especulação imobiliária e, de outro, que a preservação cultural e ambiental produza o 'retorno positivo da imagem' aos governantes, além de isenções fiscais para empresas privadas que se dispõe à preservação. Em outras palavras, o patrimônio cultural e ambiental, que era fonte de poder para o Estado-nação, torna-se simplesmente uma questão econômica e política de marketing (CHAUI, 2006: 120).

Dessa forma, grandes empreendimentos habitacionais são vendidos com o verniz ambiental, ou sustentável, como formatado pelos profissionais de marketing, quando áreas verdes privadas e selos verdes que medem a eficiência energética do empreendimento agregam valor econômico e status aos futuros moradores. Em áreas mais adensadas, como a região central de São Paulo, onde não há espaço para implantação de grandes empreendimentos fechados com seus espaços verdes privativos, a proximidade de um parque ou praça supre tal deficiência. Até para futuros moradores que não possuem o hábito de frequentar espaços públicos, a proximidade de uma área verde proporciona o valor agregado pela localização e a vista panorâmica de um entorno livre de edifícios. O trabalho de valorização de especificidade de sítios, lugares ou de cidades vem sendo substituída pela fetichização em torno dessa especificidade, com a criação de cenários turísticos e lugares atrativos para o capital ou por ideias prontas de intervenções urbanas para revitalizações de grandes cidades, que estão sendo vendidas em diversas partes do mundo.

Mesmo em relação aos grandes projetos urbanos, como os projetos de urbanização, a exemplo de Barcelona, que poderiam ser aplicados em qualquer lugar e são vendidos no circuito globalizado com o aval de consultores urbanísticos, historiadores e críticos de arquitetura contemporânea, a tônica é o processo de valorização imobiliária desencadeada pela iniciativa. Nossa linha de raciocínio coloca algumas questões em relação aos tentáculos do mercado, que tudo é capaz de processar em forma de valor de troca. Qual seria o papel da paisagem na definição do valor cultural presente? E como fazer a crítica das paisagens contemporâneas, propondo alternativas, sem que elas sejam apropriadas como produto cultural?

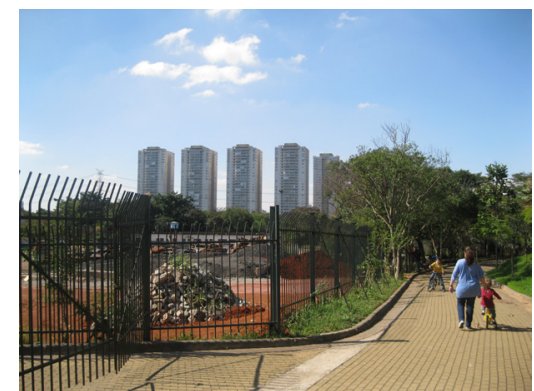

Imagem 8. Parque Raposo Tavares, nas proximidades do Jardim Jaqueline
6 Objetos ligados à ideia de patrimônio. Algo único e com significação simbólica dotada de sentido por uma coletividade. Objetos que deram início à necessidade de coleções e de seus espaços, os museus. Instituídos para afirmar uma história determinada, a dos poderosos e vencedores, concebida como una e única, linear, continua e progressiva. Cf.: CHAUÍ, 2006. 
No processo de apropriação cultural pela via do enobrecimento, que se aplica a bairros urbanos históricos, mas que pode ser considerado em intervenções nos "tecidos espontâneos" característicos das favelas,

a apropriação cultural é um processo que se dá em duas etapas. Primeiramente, um grupo social não relacionado de modo nativo à paisagem ou ao vernacular assume uma perspectiva de ambos. Em segundo lugar, a imposição de sua visão - convertendo o vernacular em paisagem - conduz a um processo material de apropriação espacial.

Esse processo, ao mesmo tempo em que provoca incentivos para reversão de estados de precariedade ou estagnação econômica, provoca processos de ressignificação e valorização capazes de afastar antigos modos de vida. Em um cenário de mercado, difícil conter tal processo de dinamização do lugar, que acaba tornando-se cenário de valorização imobiliária?.

Dentro do processo de homogeneização das paisagens pelo poder econômico, terão as classes de menor poder a oportunidade de expressar paisagens que os identifiquem? $\mathrm{E}$, caso as identidades locais se mantenham, poderão se expressar como "paisagens de resistência" ou correm o risco de se tornar imagens culturais apropriadas para consumo, ou como diz Sharon Sukin, "relíquias orwelianas"?

\section{ENCLAUSURAMENTO E APARTAMENTO SOCIAL COMO CONDICIONANTES DA} CONFIGURAÇÃO DAS PAISAGENS URBANAS

Um dos dados que chama atenção em relação à aparente dicotomia entre favela e cidade formal, no caso do Jardim Jaqueline, é a nítida fronteira existente entre as distintas paisagens locais: a favela, o condomínio, o Shopping e o lotea-

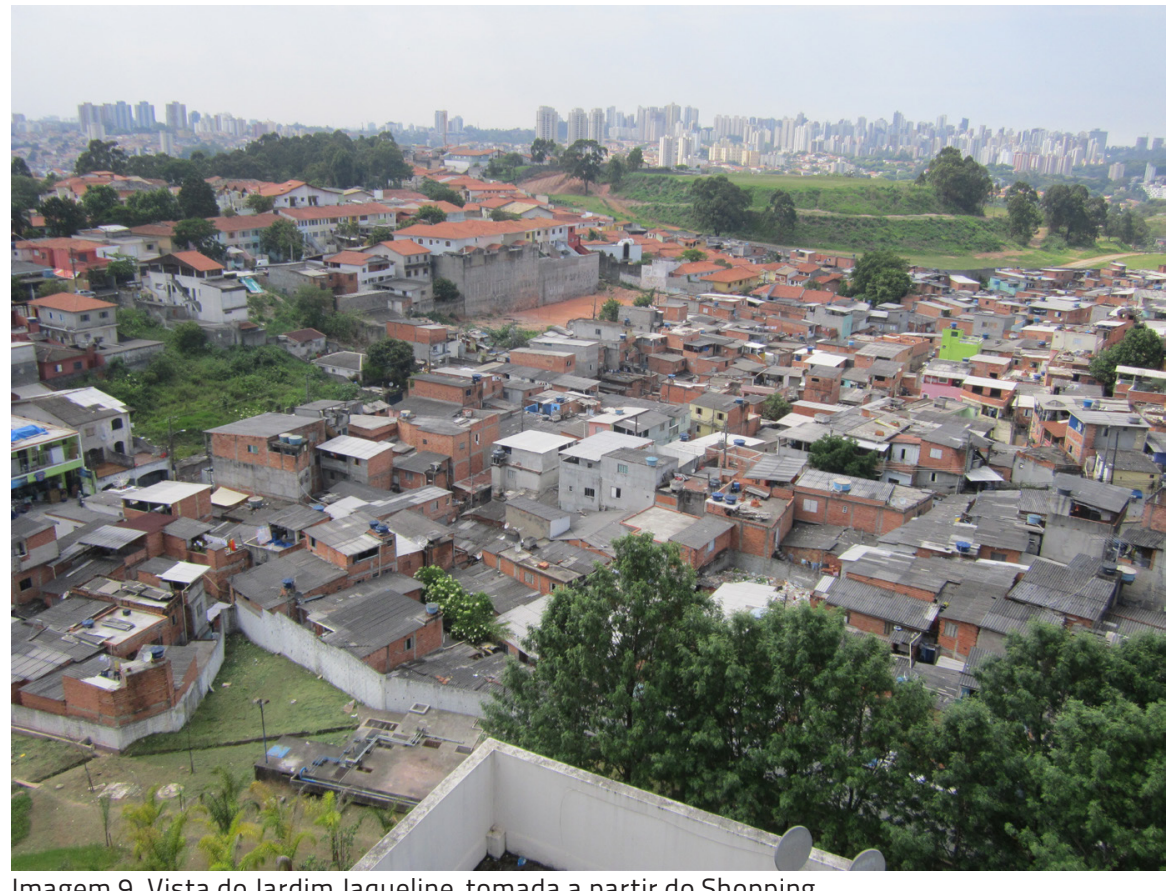

Imagem 9. Vista do Jardim Jaqueline, tomada a partir do Shopping 
mento formal. Cada unidade morfológica pode ser caracterizada de acordo com o que convencionamos chamar de paisagem; unidades de significações diversas que comportam a vida de parcelas de moradores com universos referenciais diversos. As mesmas características de isolamento encontradas no condomínio fechado, representadas por mecanismos específicos, como muros, grades e guaritas, podem ser encontrados na favela, por meio de fronteiras simbólicas que dividem a cidade informal da cidade formal. Os moradores dos bairros do entorno não adentram o espaço do condomínio fechado, da mesma forma que não adentram o espaço da favela. No lugar da guarita do condomínio, olhares dispersos na multidão controlam a entrada de "forasteiros" dentro da favela. Esses muros, reais ou simbólicos, representam os padrões de segregação que estruturam nossas cidades e que são reproduzidos no cotidiano de todas as classes sociais.

O contato com o universo cotidiano dos moradores da favela e uma entrevista realizada com uma das moradoras do condomínio fechado revelam que ambos são afetados por códigos e padrões de conduta, derivados do processo de enclausuramento urbano e segregação espacial. Apesar da nítida diferenciação social entre os moradores do entorno, todos revelam medos semelhantes em relação à violência e aos locais que não fazem parte de seus espaços "intramuros". Os moradores citam alguns locais em torno da favela como mais perigosos em relação aos espaços internos, que consideram muito seguros e tranquilos. A moradora do condomínio considera a passarela que atravessa as pistas da Rodovia Raposo Tavares como o local mais perigoso do entorno, assim como os moradores da favela, que dizem ter receio de atravessá-la durante a noite. A passarela, dentro de nosso contexto urbano, representa um local externo em relação aos domínios da favela, do condomínio fechado e do Shopping, onde não existe o controle encontrado dentro dos locais citados, seja dos seguranças contratados pelo condomínio e pelo Shopping, seja pelo poder do tráfico, que possui o controle social dentro da favela. Percebemos que, no entorno da favela, cada residência cria o seu "espaço interno", por meio de altos muros e grades. Mesmo dentro da favela podemos verificar uma divisão de territórios, marcada pela diferenciação social entre seus moradores. Quem mora na área mais consolidada não adentra o espaço conhecido como CIT, de ocupação mais precária, e simbolicamente reconhece nessa área o limite a ser considerado em um futuro projeto de intervenção, para efeitos de remoção.

Esse processo de clara divisão entre classes sociais no território urbano segue a lógica apontada por Teresa Caldeira de complexização do processo de segregação social nas grandes cidades brasileiras. 0 que antes podia ser apontado como simples relação de exclusão das periferias em relação aos centros principais, ganha novos contornos. 0 uso do desenho urbano, aliado às novas estratégias de defesa de uma classe média acuada, contribui para o processo de segregação e fortificação verificado principalmente nos bairros nobres da cidade. À medida que as elites se retiram para seus enclaves e
70 termo gentrificação, proveniente do inglês gentrification, diz respeito ao processo de substituição social associado à transformação do espaço urbano, no qual a expulsão de populações de baixa renda está diretamente associada à valorização imobiliária de áreas atingidas por projetos urbanos. Tal processo foi primeiramente teorizado pelo geógrafo britânico Neil Smith (1996). 

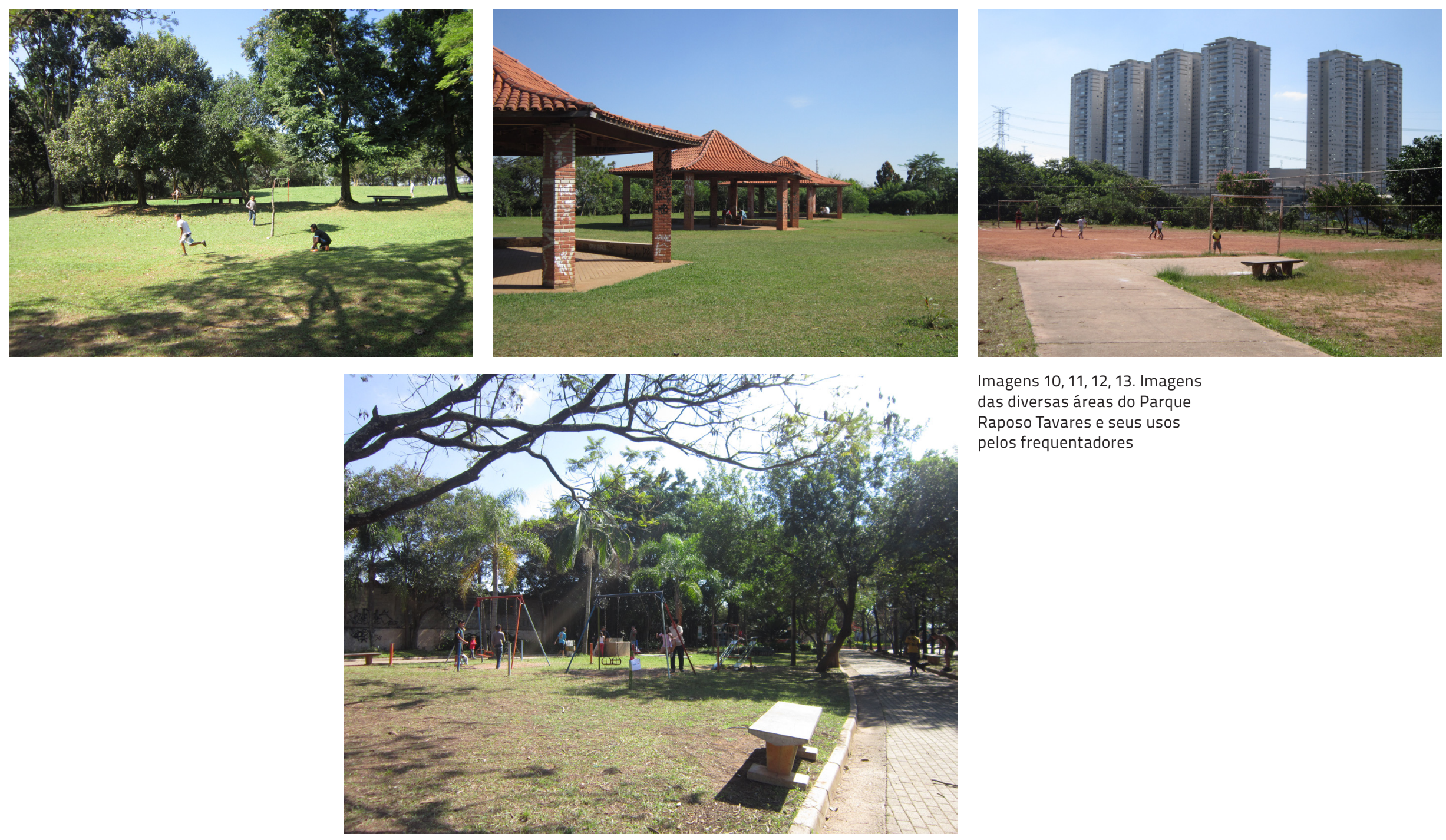

Imagens $10,11,12,13$. Imagens

das diversas áreas do Parque

Raposo Tavares e seus usos pelos frequentadores 
abandonam os espaços públicos para os sem-teto e os pobres, os espaços qualificados para encontros públicos de pessoas de diferentes grupos sociais diminui consideravelmente. "Ao transformar a paisagem urbana, as estratégias de segurança dos cidadãos também afetam os padrões de circulação, trajetos diários, hábitos e gestos relacionados ao uso de ruas, do transporte público, de parques e de todos os espaços públicos" (CALDEIRA, 2000: 301).

Os diferentes padrões de utilização dos espaços coletivos podem ser vistos no entorno do Jardim Jaqueline, no espaço público do Parque e no espaço privado de uso coletivo do centro de compras. Apesar da moradora do condomínio fechado questionar a baixa frequência dos moradores da favela no Parque, uma visita ao local em dois finais de semana distintos revelou que os moradores da favela possuíam expressiva representatividade nesses dias, o que leva à constatação de que existem diferentes padrões de frequência em dias de semana, aos quais se referiu a moradora, e nos finais de semana.

Nos finais de semana é possível ver, a partir do Parque, os espaços de lazer dos moradores do condomínio, com suas piscinas e quadras, repletas de crianças e adolescentes, ao mesmo tempo em que as quadras e campos de futebol do Parque são utilizados, predominantemente, por moradores das favelas e bairros residenciais do entorno ${ }^{8}$. Vale lembrar que, apesar da proximidade de um parque público, o condomínio fechado não possui qualquer acesso facilitado ao Parque.

Tal distinção também pode ser vista na utilização do Shopping, que recebe 8.000 visitantes, em média, durante a semana, e em um domingo recebeu cerca de 20.000 pessoas, sendo que, 11.000 pessoas adentraram o Shopping a pé ${ }^{\text {. Não }}$ podemos chegar a muitas conclusões sobre a composição dos visitantes do Shopping com tais dados, já que os moradores do condomínio fechado também frequentam o Shopping a pé, com o auxílio de segurança particular para monitorar o trajeto condomínio-Shopping, mas podemos reconhecer a predominância de acessos a pé como um fator a ser considerado diante da expressividade numérica dos moradores da favela em detrimento dos moradores do condomínio, 9.000 moradores em 3.800 domicílios residenciais da favela em relação a 672 apartamentos do condomínio.

O processo de segregação não se dá unicamente com o enclausuramento das elites receosas das novas conquistas das classes baixas, como se a população em geral tivesse adquirido novos direitos que de fato não se concretizaram. Antes, vem da necessidade dessas elites de recuperar a distinção perdida, que se não é mais exercida no mesmo espaço, passa a ser expressa pela diferente ocupação do território. Teresa Caldeira fala dessa necessidade de distinção, dando como exemplo a mistura social existente no centro de São Paulo até a década de 1960, quando pessoas de classes sociais diversas ocupavam o mesmo território, mas se diferenciavam através do porte, do vestuário e de símbolos de consumo ainda não acessíveis às classes baixas.

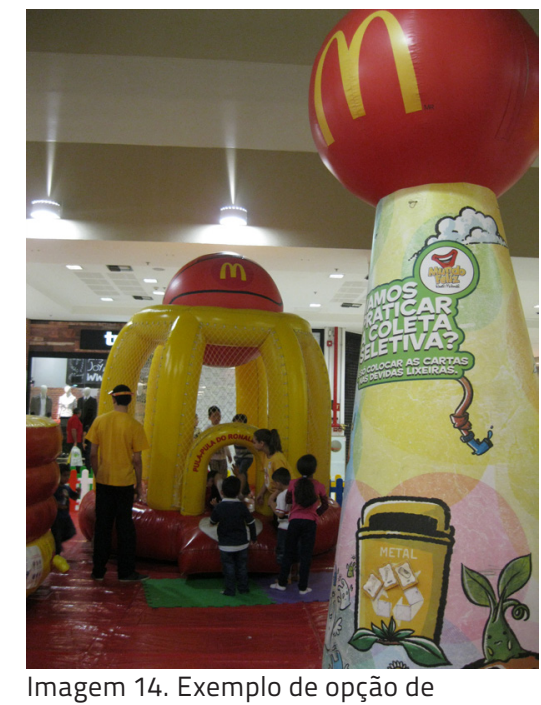

lazer dentro do Shopping

8 Constatação derivada de abordagens aos frequentadores do Parque - famílias com crianças, crianças sem acompanhantes e times que utilizavam as quadras. O Parque foi visitado em dois finais de semana, em maio e junho de 2013, e em um dia durante a semana, em novembro de 2012

9 Informações da central de segurança do Shopping, no dia 7 de julho de 2013. 
Com menos sinais óbvios de diferenciação à mão e com mais dificuldade em afirmar seus privilégios e códigos de comportamento no espaço público, as classes mais altas se voltam aos sistemas de identificação. Assim, os espaços de circulação controlada servem para assegurar que a distinção e a separação ainda são possíveis em público (CALDEIRA, 2000: 325).

Uma breve pesquisa a respeito dos novos empreendimentos comercializados em São Paulo evidencia a ideia do "privilégio" e da "distinção" associados a esses espaços. O Residencial "Smiley Home Resort", localizado na mesma região onde se situa o Jardim Jaqueline, anuncia "a oportunidade única de se morar em um residencial com jeito de resort" e o "privilégio de estar próximo ao Rodoanel", além da proximidade de ícones de consumo da classe média abastada, como escolas particulares de renome, shoppings, supermercado Pão de Açúcar, loja do McDonald's, Universidade de São Paulo (USP), além do Shopping Raposo Tavares e do Parque homônimo.

O "privilégio" em relação à proximidade com as favelas, conjuntos habitacionais de baixa renda e famosos presídios instalados nas imediações não são citados no anuncio do empreendimento. Os condomínios fechados são implantados em tecidos urbanos com diversidade social preexistentes, mas não estabelecem necessariamente relações diretas com o entorno imediato. Importante notar dentro da delimitação das redes urbanas de pertencimento divulgadas nos anúncios desses empreendimentos que a proximidade anunciada em relação a equipamentos vizinhos é relativa aos tempos gastos pelo automóvel.

Se os condomínios fechados criam o seu conceito de diferenciação social, acompanhado de comodidade e segurança, as favelas também possuem seus mecanismos de manutenção da ordem e segurança. O processo de apartamento social verificado não diz respeito somente às classes mais favorecidas, que elegeram seu modelo de habitar nas grandes cidades, mas também atinge as chamadas "comunidades", que vivem condições diversas de apropriação da paisagem, circulação e lazer. Esse processo de enclausuramento urbano entre classes favorece o apartamento social de moradores de baixa renda e a consolidação de um poder interno "intramuros", que não vem diretamente do Estado e que cria uma situação de insegurança constante por parte dos moradores.

Se considerado o contexto social mais amplo de pertencimento em relação à cidade, os moradores da favela necessitam constantemente da ação do Estado para garantia dos mecanismos de proteção social, mas não acreditam no Estado existente, principalmente na estrutura de seu sistema de segurança pública. A truculência da polícia não é bem-vinda para
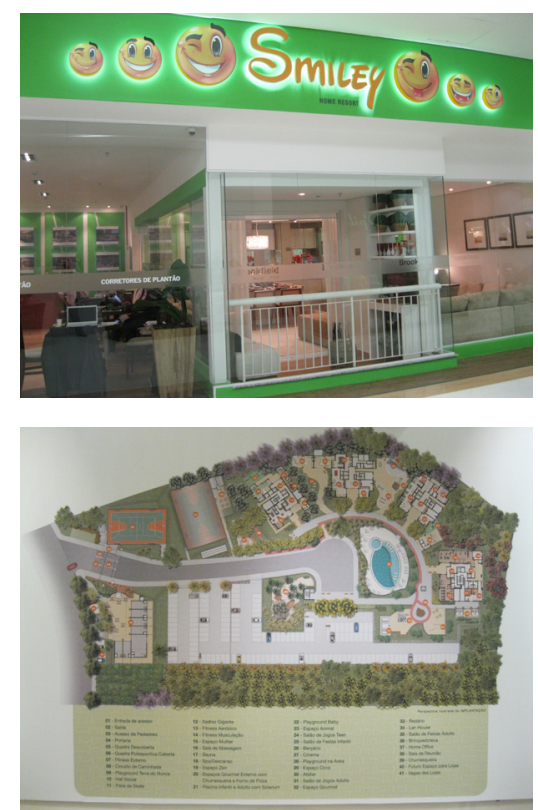

Imagens 15, 16. Imagens do empreendimento Smiley Home Resort, cujo folheto contém o texto abaixo transcrito.

"A região da Rodovia Raposo Tavares é uma ótima opção em comodidades e qualidade de vida. Viver aqui é contar

com o Raposo Shopping e estar a poucos minutos do Shopping Eldorado, além das conveniências de grandes supermercados. $O$ contato com a natureza também está garantido, com todo o verde do Parque Raposo Tavares. Aqui não vão faltar motivos para sua família sorrir.

"Brookfield Incorporações criou um verdadeiro sonho para sua família viver. Um lugar mágico, onde você pode ter conforto e muita diversão com mais de 30 itens de lazer. Venha já para o Smiley Home Resort! [...] 
resolver a violência do tráfico. Nas oficinas, presenciamos situações de indefinição em relação ao papel da segurança pública. Em situações de descontrole em relação à dinâmica interna mantida pelo "poder paralelo", não existe consenso por parte dos moradores a respeito de onde procurar ajuda. Se, para os moradores da cidade formal, parece natural chamar a polícia em uma situação de insegurança, para o morador da favela, muitas ponderações precisam ser feitas antes de um simples pedido de ajuda.

\section{OS SENTIDOS DA CULTURA DA INFORMALIDADE EXPRESSOS NAS PAISAGENS}

Adentrando a realidade social apresentada, na qual se estrutura o universo formal de um condomínio fechado, de um centro de compras e de bairros regulares, em relação ao mundo informal/ilegal da favela, buscaremos o entendimento dos universos culturais envolvidos e as relações existentes entre os chamados espaços formais e informais e os tênues limites que costuram tais divisões.

Apesar dos universos simbolicamente apartados, ora expostos, entendemos que existe uma relação direta e simbiótica entre a cidade formal e a chamada cidade real. 0 regular e o irregular se mesclam e influenciam as formas de sociabilidade locais e apropriação do espaço coletivo. As "fronteiras incertas entre o ilegal, o informal e o ilícito", configuram-se como frentes de entendimento a serem consideradas na determinação de nossa paisagem. Na medida em que reestruturação produtiva e flexibilização das relações de trabalho redefiniram as diferenças entre trabalho, desemprego e expedientes de sobrevivência, "as atividades ilícitas passam a interagir com as dinâmicas urbanas e compor o chamado bazar metropolitano" (TELLES, HIRATA, 2011: 376)10.

Apesar do transito entre o informal, o ilegal e o ilícito fazer parte de cidades marcadas por um mercado informal em expansão desde longa data, a atual matriz financeira de uma economia globalizada está ligada a uma recomposição do ilícito em suas interações com as dinâmicas urbanas (TELLES, HIRATA, 2011: 377). Nesse sentido, a escala urbana pode ser uma via preferencial para a descrição crítica do ilícito em suas relações e interações com os mercados informais, com os circuitos urbanos de circulação de riqueza e com as relações de poder inscritas em seus pontos de intersecção. A linha conceitual considerada vai ao encontro de temas desenvolvidos no capítulo que trata da pesquisa qualitativa, mas não pretende estabelecer relações diretas com o objeto de estudo, mas entre a cidade formal e cidade informal dentro do modelo de desenvolvimento urbano problematizado.

Não se trata de estabelecer relações diretas entre "poder paralelo" e configuração da paisagem, mas de procurar
[...]

"O Smiley Home Resort não se destaca só por sua exuberante área de lazer. Praticidade também é a marca do empreendimento. Logo na entrada, os moradores encontrarão um centro de conveniência com 7 lojas e um quiosque. São espaços que poderão contar com serviços como: padaria, revistaria, salão de beleza, lavanderia, locadora de vídeo, pet shop, sapataria e chaveiro 24h. Um importante diferencial que valoriza ainda mais seu patrimônio." 
meios de se problematizar ações sobre paisagens que possuem códigos de conduta diversos dos da cidade formal e "mapas subjetivos" que delimitam os espaços da favela de acordo com as regras do poder local instituído. Acreditamos que, apesar da intensa pesquisa realizada no local durante dois anos, não possuímos tais códigos internos. Como exemplo, podemos considerar o fato de que a empresa que realizou trabalhos técnicos na área durante um ano, adentrando todos os espaços físicos da favela, contou com a ajuda de um morador local, que acompanhou os passos de sua equipe diariamente, a fim de indicar as posturas que deveriam ser adotadas nos levantamentos de campo, como locais que não deveriam ser fotografados ou horários mais adequados para os levantamentos em determinados locais. Em nossa pesquisa, todas as nossas incursões pelos espaços da favela foram acompanhadas pelas lideranças locais, que nunca restringiram qualquer intenção da pesquisadora em relação aos locais visitados, como fotos ou conversas com moradores.

Para Telles e Hirata, o foco de suas pesquisas sobre a gestão dos ilegalismos inscritos na vida cotidiana não é o tráfico de drogas em si, mas a "crescente e ampliada zona de indiferenciação entre o legal e o ilegal, o lícito e o ilícito, que só podem ser compreendidos em 'constelações situadas', a partir de cenas descritivas de locais específicos" (TELLES; HIRATA, 2011: 379). No assentamento irregular investigado por Telles e Hirata podemos presenciar: as redes oficiais de infraestrutura, que chegam de forma fragmentada, dividindo espaço com os "gatos" ou ligações clandestinas; os empregados terceirizados das concessionárias de luz e telefone, com seus salários precários e sem estabilidade, que complementam suas rendas com os serviços clandestinos prestados aos moradores - que levam a questionarmos se seriam as atuais "terceirizações" no universo do trabalho "formal" uma porta de entrada para o mercado informal; o traficante local, respeitável pai de família, e ex-empregado do mercado formal; a dubiedade das relações com a polícia; as melhorias locais que seguem o calendário eleitoral; o assistencialismo operado, ora pelas relações legais, ora pelo tráfico; e a forte liderança que possui familiares em diversas situações, entre o legal, o ilegal e o ilícito. Tais fragmentos formam as "minúsculas histórias"11 que fazem parte do cotidiano local.

Os pesquisadores identificam como a gestão cotidiana do negócio da droga está ancorada nas redes de sociabilidade locais. O cotidiano deve ser controlado e cada fato que possa chamar atenção da polícia ou causar descontentamento dos moradores deve ser solucionado, como forma de se manter o "equilíbrio instável" local. Da mesma forma que o equilíbrio interno é mantido pelas tessituras sociais internamente estabelecidas, a gestão oficial por parte do poder público das populações "em situação de risco" estabelece uma forma de controle peculiar, por meio da "[...] gestão das populações, gestão das vidas e, nesses tempos em que a exceção se tornou a regra, a administração de suas urgências para tornar os 'indivíduos
10 Os autores utilizam-se do termo "bazar metropolitano", tirado do artigo "A Cidade como Bazar", de Ruggiero e South (1997). 
governáveis' sob a égide da racionalidade triunfante do mercado".

Apesar de fugir dos objetivos propostos para a pesquisa, não podemos deixar de falar do modelo de intervenção do Estado nas favelas cariocas, por meio da implantação das UPPs (Unidades de Polícia Pacificadora) ${ }^{12}$. Existem estudos a respeito da gestão militarizada da segurança pública e da vida social, refletidas no urbano, que apresentam preocupantes constatações a respeito da estrutura do tráfico em favelas ocupadas pelas UPPs: "A crise tornou os 'comandos' da droga mais fragmentados, irracionais e autodestrutivos. Eles deixam de representar uma alternativa econômica, ainda que perigosa e ilegal, e tendem a se tornar núcleos de pura violência"13. Perante a desestruturação social causada pelas UPPs em territórios que possuíam suas relações internas - onde a polícia militar não consegue se estabelecer socialmente, mas apenas por meio da violência -, o saldo é a permanência de um sentimento de insegurança por parte dos moradores locais e um processo de intensa valorização imobiliária, decorrente do interesse de novos moradores pela área supostamente livre da violência do tráfico.

Como vimos no capítulo que trata da pesquisa qualitativa, o ilegal e o ilícito, articulados à gestão das urgências "são a forma de fazer girar o capital" e de sobreviver às adversidades. Ao mesmo tempo que os moradores do Jardim Jaqueline se sentem seguros dentro de uma ordem interna constituída, reconhecem os incômodos causados por uma ordem econômica interna que cerceia os direitos dos moradores à livre circulação em determinadas horas, ao sono nos finais de semana, e aos espaços livres coletivos, ocupados pelos pequenos negócios responsáveis pelo "giro de capital". Mesmo reconhecendo as perdas sofridas, ponderam que as determinações do poder local são preferíveis ao poder militarizado da polícia. Além das ações apontadas de desrespeito à população, a polícia não é acatada, devido às relações dúbias estabelecidas com o tráfico.

A atuação do poder público na favela se resume à administração das urgências, associadas aos "riscos" socialmente legitimados pela cidade formal, como o risco geológico, o risco nutricional, o risco associado à saúde pública e educação. Mesmo as urgências são mal equacionadas, já que o crescimento da favela não veio acompanhado dos equipamentos básicos necessários. Em meio às necessidades básicas mal resolvidas, com esgoto correndo a céu aberto em diversos trechos da favela, seus moradores vivem em um universo simbólico unificado pelo consumo, onde o ilegal e o ilícito se configuram como "oportunidade econômica e participação no mundo simbólico dominante". Podemos afirmar que uma das principais representações na favela, que diz respeito à cultura local, é o poder unificador do consumo, que aproxima as diferentes estratificações sociais locais e os moradores locais em relação à cidade formal.

No Jardim Jaqueline, as lideranças locais colocam essa importante questão em suas falas, quando reconhecem que
11 Ou "existências destinadas a passar sem deixar rastro", de acordo com Michel Foucault ([19--]), citado pelos autores.

12 Dados do Instituto de Segurança Pública (ISP) mostram que houve aumento no número de desaparecimentos nas 18 primeiras comunidades que receberam UPPs (Unidades de Polícia Pacificadora), no período entre 2007 e 2012 (ANDRADE, 2013). Por outro lado, os imóveis em favelas onde foram instaladas as UPPs estão passando por forte processo de valorização (O GLOBO, 2010).

13 Apresentação do livro Até o último homem: Visões cariocas da administração armada da vida social(2013), de Felipe Brito (org.) e Pedro Rocha e Oliveira (org.). Disponivel em: <http://www.boitempoeditorial.com.br/livro_completo. php?isbn=978-85-7559-287-8>. Acesso em: 10 Ago. 2013. 
os moradores da favela possuem os mesmos objetos de consumo das classes mais favorecidas, como eletrodomésticos, computadores, celulares de última geração e carros, ressaltando que o último símbolo de consumo a ser conquistado é a propriedade de suas casas. Tal dado é relevante para o entendimento dos papéis diversos desempenhados pelos agenciamentos locais e pelo universo formal no atendimento das demandas dos moradores. Se as forças locais instituídas conseguem prover a favela de muitos bens de consumo necessários à vida moderna, como no caso dos mais diversos gatos, ligados à rede elétrica, telefonia e TV a cabo, existem limites que necessitam da intervenção do poder público, como equipamentos urbanos e o poder de regulação sobre a propriedade da terra ${ }^{14}$.

A habitação é a última trincheira do campo de consumo a ser conquistado pelas classes menos favorecidas. As ações do governo federal indicam o caminho para o atendimento dessa última demanda com o programa "Minha Casa Minha Vida", que tem como objetivo o atendimento habitacional em larga escala de acordo com padrões do mercado. Como a finalidade do trabalho não é a discussão sobre o programa, fica colocado somente seu papel como reprodutor de uma lógica de mercado (ideológica) que vem somar forças dentro de um contexto universal de reprodução do capital.

O que merece ser discutido em nossa pesquisa é a maneira como os padrões de reprodução das moradias da baixa renda estão comprometidos com um padrão de consumo ditado pelas classes hegemônicas, mas atrelados à capacidade de consumo de cada morador. Isso significa que, embora as diversas classes sociais possuam níveis diferentes de apropriação do território, ligados a capacidades materiais diversas, que levam a padrões diversos de fruição e deslocamentos, os ideais de consumo em relação ao território são os mesmos, ditados por poderosos mecanismos de comunicação das classes dominantes. A moradia pode ser distante dos grandes centros, mas vem acompanhada de um título de propriedade e de todos os símbolos necessários para a formação de uma "cidadania paramentada", com os eletrodomésticos e o automóvel.

A ação do Estado nesse cenário é clara: o atendimento habitacional de mercado, para quem tem poder de compra para tanto, e a gestão dos riscos associados a uma população que não possui renda suficiente para conquistar as ofertas do chamado mercado popular.

\section{O IDEAL DO HOMEM QUE HABITA}

Para o entendimento da conjuntura social em que se encontra essa classe sem renda suficiente para adentrar o universo de consumo estabelecido pelo mercado - que é local, mas que possui determinações globais -, tomaremos como partido o entendimento de Boaventura de Sousa Santos a respeito da evolução dos ideais de subjetividade, cidadania e
14 Lembramos novamente que a maior matrícula onde se insere o Jardim Jaqueline é, potencialmente, da prefeitura municipal, restando somente um ato cartorário para tornar a área, de fato, da municipalidade. Lembramos também que o poder público se esquivou de atuar sobre a área com o argumento de que se tratava de área particular. Fonte: Ata de reunião entre secretaria de habitação e moradores do Jardim Jaqueline em 2007. Acervo de documentos da União de Moradores do Jardim Jaqueline. 
emancipação em relação ao nosso contexto político liberal globalizado ${ }^{15}$.

O autor distinguiu quatro espaços políticos estruturais dentro de nossa formação política liberal: o espaço da cidadania (espaço político da teoria liberal); o espaço doméstico (espaço privilegiado de reprodução social e de suas formas de poder); o espaço da produção (espaço da exploração da mais-valia); e o espaço mundial. Existiriam diversas formas de tensionamento possíveis para a ampliação da politização das estruturas existentes dentro de cada espaço. Mas é em relação à politização do espaço mundial que o autor encontra entraves que dizem respeito ao nosso objeto de estudo, enraizado em um contexto específico: o processo de transnacionalização da produção e a ideologia do consumismo, que seria a "estratégia simbólica do capitalismo transnacional no sentido de integrar na lógica do consumo todas as classes sociais do sistema mundial e muito especialmente as classes populares dos países periféricos e semiperiféricos".

As empresas multinacionais são os grandes veículos da cultura-ideologia do consumismo e tem desempenhado um papel crucial em aumentar expectativas consumistas que não podem ser satisfeitas, num futuro previsivel, pela massa da população do chamado terceiro mundo (SANTOS, 2010: 275).

Essa constatação mostra-se crucial para o entendimento da vida nas favelas brasileiras. Seus moradores, assim como todos os moradores da cidade, encontram-se anestesiados por ideais de consumo que poucos "cidadãos" são capazes de satisfazer. Nossas reais necessidades estão muito aquém das apregoadas pelos meios de comunicação, que vinculam insistentemente personalidades a objetos de consumo. Podemos ver essa relação de personificação dos bens materiais nas propagandas de automóveis, que associam diretamente o modelo ou marca do produto às características físicas do usuário. Em São Paulo, chegamos ao ponto de ter em circulação nas ruas grande quantidade de veículos chamados de SUV ${ }^{16}$, com características incompatíveis em relação às nossas necessidades de circulação e áreas disponíveis para estacionamentos. Tal "necessidade" vem induzindo o aumento do tamanho das vagas de estacionamento, adaptadas às novas demandas dos consumidores contemporâneos. Sabemos que a lógica de consumo vigente em relação ao uso indiscriminado do transporte individual possui impacto ambiental direto nos grandes centros urbanos, seja pela poluição gerada pela crescente frota de veículos motorizados, seja pelo padrão de uso e ocupação do solo, que privilegia grandes áreas de estacionamentos em níveis de subsolo, que impermeabilizam totalmente o solo. Nesse ponto, estamos adentrando a real problemática em torno da questão da sustentabilidade nas grandes cidades, que as classes dirigentes não desejam inserir em seus discursos.
15 Apesar do posicionamento crítico em relação ao alinhamento marxista a que pertence grande parte dos autores aqui utilizados, não podemos negar que Boaventura utiliza Marx como importante referencial teórico. Interessa-nos em nosso desenvolvimento seu processo de conceituação a respeito da construção liberal da democracia representativa e do potencial de emancipação de grupos situados em contextos políticos e econômicos próprios. Entendemos que $o$ autor se destaca em relação ao seu ativismo político e à importância central dos trabalhos de campo em suas pesquisas. Encontramos análises do trabalho de Boaventura que questionam sua interpretação dos conceitos marxistas de totalidade, da centralidade do trabalho e da noção de progresso, que levariam às contradições encontradas em sua crítica ao Marxismo. Disponível em: <http://www.ifch.unicamp.br/formulario_cemarx/selecao/2009/trabalhos/ desdobramentos-da-concepcao-de-boaventura-de-sousa-santos-so.pdf>. Acesso em: 27 Jan. 2014.

16 Do inglês Sport Utility Vehicles, os SUVs são veículos com capacidade para andar fora das áreas urbanas, em terrenos acidentados, e são característicos por seu porte avantajado e por possuírem tração nas quatro rodas. 
A mesma lógica penaliza a vida nas favelas. Desenhos urbanos espontâneos consolidados, como o do Jardim Jaqueline, construído de acordo com a lógica do pedestre, com vias estreitas e ausência de separação entre tipos de circulação, carro e pedestre, não comportam o incrível crescimento da frota motorizada. Pedestres disputam espaço com a circulação de carros e áreas de lazer improvisadas dão lugar a vagas de estacionamento. Os moradores do Jardim Jaqueline relatam a dificuldade de implantação do campo de futebol oficial da favela pela disputa com os proprietários de veículos que não queriam perder suas "vagas" sobre a área do campo. Seguindo a lógica do restante da população da cidade formal, não se questiona na favela a necessidade do automóvel ou a vinculação direta com o sistema de transporte coletivo de qualidade.

Podemos constatar que essa construção ideológica que privilegia a utilização do automóvel individual permeia todas as classes sociais, mas penaliza principalmente as mais frágeis, que estão fora do ambiente de consumo construído e são obrigadas a depender exclusivamente do transporte público ${ }^{17}$. São duplamente penalizadas pelos espaços livres perdidos no universo de seus locais de residência e pelo espaço de circulação perdido em seus trajetos urbanos.

A importância assumida pelos ideais de consumo aniquila a dimensão pública dos espaços físicos e sociais, fazendo com que os espaços públicos restantes sejam aos poucos corroídos pelas necessidades privadas de pequenos "proprietários", muitas vezes ligados a circuitos econômicos mais amplos, que legitimam a perda do espaço coletivo, em detrimento de necessidades partilhadas de consumo e gestão das adversidades. 0 universo referencial coletivo amplamente tomado pelos ideais de consumo generalizados relativizam as necessidades humanas anteriores a esses ideais, ligadas à fruição dos espaços livres, à memória coletiva e a temporalidades relacionadas ao lazer.

As reivindicações de grupos excluídos, como o direito à propriedade e aos padrões de consumo das elites, passam pelos mesmos ideais de pertencimento em relação a esse conjunto ideologicamente homogêneo, enfraquecendo qualquer possibilidade de ruptura com a estrutura social que sustenta a concentração de renda. Para entender os resultados das oficinas realizadas na favela, com os ideais coletivos revelados e suas necessidades latentes, devemos entender um pouco o contexto global em que tais aspirações de assentam, com o devido cuidado de não ampliar a discussão a ponto de perder os objetivos da nossa investigação.

\subsection{SUBJETIVIDADE, CIDADANIA E EMANCIPAÇÃO: UMA EQUAÇÃO EM CONSTANTE (DES)EQUILÍBRIO}

Para inserir a lógica de reprodução das paisagens locais, especificamente da reprodução dos espaços de moradia dos excluídos do mercado formal, dentro de uma lógica ideológica-cultural hegemônica e propor caminhos para emancipa-
17 Mesmo o transporte público é muito oneroso para as faixas de renda inferiores a três salários mínimos. O valor cobrado pela passagem de ônibus em São Paulo, R\$3,00 (em agosto de 2013) representa $15,9 \%$ da renda de um trabalhador que ganha um salário mínimo (passagemida evolta, consideranc dias no mês, com salário mínimo paulista de $\mathrm{R} \$ 755,00)$. Se o trabalhador necessitar de uma integração intermodal entre ônibus e metrô, o comprometimento na renda será de $24,6 \%$. 
ção, vamos utilizar o desenvolvimento teórico de Boaventura de Sousa Santos (2010).

Apesar de concordar com Michel Foucault - que denuncia que o excesso de controle social produzido pelo poder disciplinar e pela normalização técnico científica reduz, ao mais baixo custo, o potencial político das populações, domesticando seus corpos e maximizando sua utilidade social -, Santos insere o projeto da modernidade dentro de uma relação de equilíbrio entre regulação e emancipação. O pilar da regulação seria constituído por três princípios: o princípio do Estado, o princípio do mercado e o princípio da comunidade. O pilar da emancipação estaria estruturado em torno de três dimensões de racionalidade: a racionalidade moral prática, do direito moderno; a racionalidade cognitivo-experimental, da ciência e da técnica modernas; e a racionalidade estético-expressiva, das artes e da literatura modernas (SANTOS, 2010: 236).

À medida que a trajetória da modernidade se identificou com a trajetória do capitalismo, o pilar da regulação veio a fortalecer-se à custa do pilar da emancipação, e dentro desse, a racionalidade cognitivo-instrumental da ciência e da técnica desenvolveu-se em detrimento das demais, com a progressiva hegemonia das epistemologias positivistas. Essa hegemonia das ciências tecnicistas é muito clara em nossa vida prática, principalmente quando analisamos as opções adotadas nas gestões públicas e dentro do ambiente acadêmico nas universidades. A "técnica competente", acompanhada de seus índices de produtividade, facilmente mensuráveis por gráficos e tabelas, vem ganhando espaço de destaque em nosso cotidiano.

De acordo com esse particular equilíbrio, legitimado pela teoria política liberal, o princípio do mercado se destaca em relação ao princípio do Estado e ambos se sobrepõem ao princípio da comunidade. Dentro dessa lógica, o Estado cumpre o papel de garantir a segurança da vida e da propriedade, de acordo com as regras naturais da propriedade e do mercado (SANTOS, 2010: 237). Nada mais natural, dentro dessa lógica, do que incluir a população excluída do princípio do mercado, que demandaria a atuação direta do Estado, segundo a regra vigente, dando títulos de propriedade ou auxílios financeiros provisórios que acabam aquecendo o mercado de vendas ou o mercado de aluguéis. Os tais princípios fundamentais, que garantiriam a moradia adequada e todos os outros direitos derivados da boa localização na cidade - como acesso a transporte, saúde e educação -, são tão intangíveis e pouco inseridos dentro dessa lógica tecnocrática mensurável, que continuam negligenciados, com a chancela do Estado.

A negligência do direito à paisagem caminha na mesma chancela, mas com o agravante de sequer ser reconhecido como um direito fundamental, mas como um valor subsidiário dentro das questões que envolvem patrimônio histórico e cultural. Como discutir questões de fruição e qualidade de vida dentro do ambiente construído (paisagem) em um cenário de precariedade extrema? Voltamos à nossa questão de origem, que diz respeito à totalidade dessa paisagem.
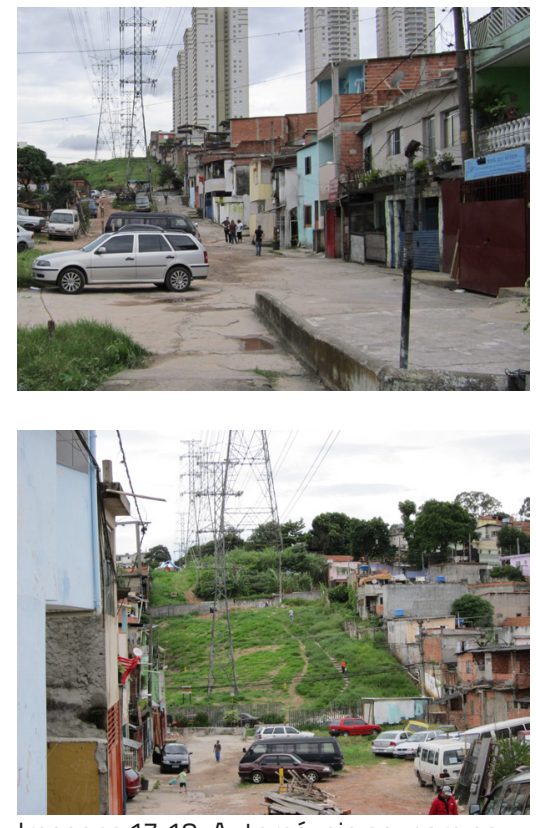

Imagens 17, 18. Automóveis ocupam os espaços livres restantes da favela, como os espaços sob a linha de transmissão da Eletropaulo. 
Em relação à questão da subjetividade, diferentemente do que profetiza a teoria política liberal, o princípio da subjetividade seria muito mais amplo que o princípio da cidadania, visto que "o princípio da cidadania abrange exclusivamente a cidadania civil e política e o seu exercício reside exclusivamente no voto. Quaisquer outras formas de participação política são excluídas ou desencorajadas" (SANTOS, 2010: 238). A sociedade civil é concebida de forma monolítica, ocultando formas associativas como as empresas e a família, que permanecem fora do contrato social liberal e das obrigações políticas, portanto, impermeáveis à politização. A construção liberal da cidadania, que nivela a individualidade ao que nela há de universal, faz parte de um contrato social, que inclui o limite dos poderes do Estado e o controle social necessário para a supremacia do princípio do mercado. Distinções de nascimento, classe social, educação e ocupação, apartadas de sua dimensão política, são socialmente naturalizadas e intocadas pelo princípio da igualdade da cidadania política.

Tal tessitura do principio da cidadania molda o cotidiano da população de baixa renda, elevada à condição de cidadãos sazonalmente, nos períodos de campanha eleitoral ${ }^{18}$, e delegados ao esquecimento quando se trata das demais dimensões da cidadania. Devemos lembrar que todas as "conquistas" alcançadas em relação à favela estudada são derivadas dessa dimensão de cidadania de seus moradores: o poder do voto. Nesse viés, Marilena Chauí, sobre a construção da política de cidadania cultural em sua experiência como Secretária de Cultura do Município de São Paulo na gestão de Luisa Erundina, assevera que as prioridades de atuação em uma cidade marcada por carências profundas e privilégios cristalizados são claras: garantir direitos existentes; criar novos direitos; e desmontar privilégios (CHAUí, 2006: 65). À luz de nosso objeto de estudo, percebemos como sua tríade de atuação é facilmente identificável, porém de difícil equacionamento, principalmente no que se refere ao desmonte de privilégios, tão arraigados em nossa conformação social.

De acordo com Boaventura Sousa Santos, o processo de construção da cidadania social só se consolida após a Segunda Guerra Mundial, graças ao tensionamento do princípio da comunidade, representado pelo campo das lutas sociais da classe operária. Nesse processo de construção, o autor diferencia três níveis do direito relacionados à cidadania: os direitos cívicos, vinculados ao primeiro momento de desenvolvimento da cidadania, apoiados nas instituições do direito moderno e do sistema judicial; os direitos políticos, mais tardios e de universalização mais difícil, traduzidos no sistema eleitoral e político; e os direitos sociais, conquistados pelas classes trabalhadoras e representados pelo Estado-providência.

Apesar do histórico de conquistas sociais representar o alargamento da cidadania, ele também contribue para o processo de aprofundamento da regulação em detrimento da emancipação:
18 Vale lembrar que até essa dimensão prática do princípio da cidadania, que é o voto, é questionada por parte da elite dirigente do país. Segmentos conservadores da sociedade lançam companhas na rede mundial de computadores para impedir o voto de segmentos da população que necessitam de auxílios sociais do governo, como o Bolsa Família. 
Apesar de aparentemente contraditória, tal afirmação vai ao encontro de exemplos que conhecemos de conquistas sociais alcançadas em relação à urbanização de favelas, por exemplo, onde ganhos sociais obtidos também podem representar o cerceamento de modos de vida possíveis dentro de faixas de renda que não conseguem sobreviver na "cidade legal". Ao contrário do que diz o censo comum em relação às diversas irregularidades verificadas nas favelas - que "favelado não quer pagar conta" -, o que ocorre é que a ilegalidade é a única forma de inserção urbana de grande parte da população das grandes cidades, que não alcançam a renda necessária para arcar com os custos da regularização. Como profetiza uma das lideranças do Jardim Jaqueline: com a regularização da energia elétrica "vocês serão vítimas da Eletropaulo"19.

Em relação à chamada "indústria dos tempos livres" é fácil constatar nas grandes cidades a atomização do lazer e dos tempos livres nos finais de semana de levas de trabalhadores, que se colocam dentro dos mesmos espaços fechados em que vivem cotidianamente, para completar suas necessidades de lazer e consumo, ou simplesmente de consumo, já mimetizado com o lazer. É sintomático constatar que o Shopping Center Raposo Tavares recebe mais visitantes nos finais de semana que o Parque homônimo vizinho ${ }^{20}$. Ou ouvir de moradores do Jardim Jaqueline que quem não frequenta o Shopping, gostaria de utilizá-lo como espaço de lazer, mas ainda não o faz porque não possui renda suficiente para suprir as vontades de todos os filhos, que geralmente passam de dois por família. Trata-se da constatação de que tais cidadãos, fortemente influenciados pelos ideais de uma classe média que redefine suas subjetividades, querem fazer parte dos mesmos espaços de consumo, também transformados em espaços de lazer. E o Parque?

\section{A PAISAGEM DA FAVELA DENTRO DE UM CONFLITO ANUNCIADO}

Com a apresentação do cenário sociocultural em que estão imersos os moradores do Jardim Jaqueline e das cidades em geral, não estamos procurando o esgotamento de possibilidades em relação às paisagens urbanas colocadas, mas

19 Comentário proferido na primeira oficina realizada com os moradores do Jardim Jaqueline, no âmbito da presente pesquisa. Cf. Capítulo 2.

20 De acordo com o relatório Parques Paulistanos - Estudo sobre uso e manutenção, elaborado pelo Sindicato Nacional das Empresas de Arquitetura e Engenharia Consultiva, em 2008, o Parque Raposo Tavares recebe cerca de 3.280 pessoas por mês. Disponivel em: <http:// www.nossasaopaulo.org.br/portal/files/ EstudoParques.pdf >. Acesso em: 10 Ago. 2013.

De acordo com a central de segurança do Shopping homônimo, nele são esperados cerca de 28.000 frequentadores por semana. 
um entendimento das dimensões a serem enfrentadas em qualquer ação possível sobre a paisagem. Não podemos difundir o erro de reproduzir juízos de valor que dividem os padrões de ocupação aceitos e não aceitos, que repudiam a paisagem das favelas e enobrecem os condomínios fechados. Quais são os critérios? Ambientais? Será que os condomínios fechados são melhores, do ponto de vista ambiental, do que as ocupações das favelas? Quais valores reproduzimos quando aceitamos a remoção total de famílias de suas moradias em nome de uma qualidade ambiental representada pelos parques lineares e consideramos adequada a implantação de condomínios fechados com seus subsolos de estacionamentos que impermeabilizam completamente o solo? Somos tão coerentes em nossas convicções quanto os jardins construídos sobre as lajes desses estacionamentos.

Da mesma forma, não podemos aceitar ações locais desvinculadas das práticas, com argumentos de que os universos sociais encontram-se indiferenciados pelo poder do consumo e que, portanto, as classes menos favorecidas economicamente não teriam capacidade para gerir os espaços coletivos, dada a crise dos espaços públicos. A ação sobre a paisagem deve ter como objetivo a superação de um espaço urbano enclausurado e segregado e não diz respeito apenas aos espaços físicos, mas principalmente a uma construção coletiva que deve contar necessariamente com a participação dos moradores locais, ou cidadãos, considerando a cidade da qual fazem parte ${ }^{21}$.

Se a paisagem é "Expressão física, morfológica da interação da sociedade com o processo do suporte ecológico no tempo e inclui não apenas, os espaços livres e construídos, mas igualmente, a dinâmica das relações sociais, o inerte e o vivo, os objetos e as pessoas"22, estamos falando em uma dinâmica de construção da paisagem que trabalhe a dimensão social envolvida a ponto de alterar as estruturas físicas locais como parte de uma intenção coletiva partilhada.

Nessa dinâmica, podemos constatar que o instrumental teórico utilizado por técnicos e acadêmicos não possui permeabilidade na vida prática da população e que as dinâmicas sociais que levam à ocupação de áreas de proteção ambiental não são consideradas pelos responsáveis pela formação do conhecimento e pelas políticas públicas. Não podemos omitir as relações "informais" estabelecidas entre a população que ocupa áreas ambientalmente frágeis e o poder público, ao longo do tempo, como relatam os moradores do Jardim Jaqueline, que dizem que, no início, a ocupação contou com certa "conivência" da municipalidade ${ }^{23}$.

Um dos grandes desafios colocados por um projeto de intervenção na área é a conciliação entre o conhecimento técnico e acadêmico e o saber cotidiano dos usuários do lugar. A importância desse conhecimento cotidiano, somente possível para quem habita o local estudado, ficou clara no momento em que os moradores locais demonstraram um nível de
21 Sobre os conflitos e contradições inerentes aos processos participativos, ver: LIMA, Catharina. Parque Pinheirinho d'Água: a luta por reconhecimento e visibilidade.

22 SANTOS, Catharina P. C. Anotações em sala de aula, disciplina "A paisagem no desenho do cotidiano (AUP 5834)". Revista da Pós-graduação, FAU-USP, no prelo.

23 As lideranças locais dizem que nunca encontraram qualquer resistência ao processo de ocupação do Jardim Jaqueline e que, quando apareceram os primeiros técnicos da prefeitura, a única restrição imposta foi a manutenção da faixa não edificante do córrego, cujo comprimento os moradores desconhecem ou dizem desconhecer. 0 único proprietário que demonstrou resistência ao processo de ocupação foi 'o do chapeuzinho" (se referindo aos judeus), que teria proposto às lideranças locais a transferência dos moradores da área da CIT (área mais precária) para um terreno em Cotia. 
conhecimento físico e, principalmente, socialmente construído do objeto estudado mai preciso e qualitativamente superior à base oficial existente. "a nascente que ficava no terreno do Shopping", "o terreno onde se jogava futebol" ou "a árvore que representava a praça" são lembranças de locais que já não existem, mas são indícios de hábitos urbanos e relações com o espaço perdidos, podendo ser resgatadas na adoção de partidos de projetos, que seriam mais facilmente reconhecidos pelos moradores. Esse processo de resgate deve ter o cuidado de valorizar as potencialidades sem romantizar uma estrutura urbana e ambiental precária.

A prospecção de potencialidades em meio a uma paisagem precária deve contar com a sensibilidade da abordagem, onde, por exemplo, as questões relativas ao meio ambiente não devem ser colocadas de acordo com sua roupagem tradicional conservadora e hipócrita. Pudemos constatar em outras pesquisas participativas ${ }^{24}$, que questões frenquentes apontadas pelo universo pesquisado como: "Qual é função ambiental de uma APP de um córrego canalizado?" ou "Por que temos que manter áreas permeáveis em nossos quintais se as vias são pavimentadas e o córrego é canalizado?" não podem ser adequadamente respondidas, por falta de argumentos técnicos ou científicos convincentes. Como falar em dinâmica ambiental de uma microbacia e responsabilidades individuais quando o poder público negligencia todas as escalas analisadas? Não podemos exercer o papel de reprodutores de nosso conexto ideológico sobre meio ambiente urbano, com o discurso que associa as baixas rendas à degradação dos cursos d'água urbanos. O processo de ocupação de áreas ambientalmente frágeis, se considerado a partir de uma matriz única, ambiental ou habitacional, corre o risco de reproduzir o conflito travado no universo prático de reprodução das cidades.

Outra linha ideológica corrente a ser questionada é a que associa a carência de projetos habitacionais em áreas providas de infraestrutura à ausência de espaço. Essa mesma determinação ideológica flexibiliza a construção de habitações para as baixas rendas em áreas ambientalmente frágeis, ao mesmo tempo que restringe as mesmas construções nas áreas mais valorizadas da cidade ${ }^{25}$. 0 exemplo do Jardim Jaqueline deixa muito claro que existem diversas opções para realocação de moradores da favela, se o real objetivo for a conciliação entre habitação e preservação ambiental. Constantemente são colocadas falsas questões à população fragilizada das grandes cidades, como as escolhas entre moradia e meio ambiente, implícitas quando os processos de remoção se dão por "riscos" ou desocupação de margens de córregos, escolha entre equipamentos diversos, como parque ou escola, praça ou creche, campo de futebol ou posto de saúde. São escolhas desonestas colocadas a uma parcela da população que ainda não possui a consciência da dimensão dos direitos que possui. Na verdade o poder público tem a obrigação de prover moradias, com equipamentos básicos, incluindo entre eles o lazer e o chamado
24 Cito aqui a disciplina cursada no programa de pós-graduação da FAU-USP, 'A Paisagem no Desenho do Cotidiano Urbano (AUP 5834)", que teve como objeto o estudo a sub-bacia do Córrego Taioca, no município de Santo André (SP). A disciplina contou com oficinas participativas, com a presença da academia, dos gestores públicos e atores sociais envolvidos.

25 Decretos da prefeitura municipal de São Paulo regulamentam a construção de Habitação de Interesse Social nas Áreas de Preservação Permanentes (APPs) ao mesmo tempo que restringem os mesmos empreendimentos em Áreas Exclusivamente Residenciais (AERs), áreas notórias de residência de parcelas das elites que possuem o privilégio de viver em áreas residenciais horizontais e bem localizadas no tecido urbano da metrópole. Decretos $n^{\circ} 51.674$, de 30 de julho de 2010, e n ${ }^{\circ}$ 54.074, de 5 de julho de 2013. 
meio ambiente, por meio de parques, praças e espaços de contemplação.

[...] a questão é que diante de demandas urgentes e vendo-se impelida a negociar para o estabelecimento de prioridades de sobrevivência, a população da periferia encontra-se, na barganha política, na obrigação de optar por uma das reivindicações para não ficar sem nenhuma, o que concorre para um imaginário de que o atendimento a prioridades tão básicas inviabiliza as outras que parecem, então secundárias (LIMA, 2013).

Ao estudar o processo de criação e consolidação da favela Jardim Jaqueline - considerando o conflito entre ocupação humana e meio ambiente e a contraposição entre políticas públicas de habitação de interesse social e preservação ambiental do município e sua ação específica em relação à favela -, propomos um método de abordagem em relação ao espaço habitado, em que a habitação e o meio ambiente não são considerados meios distintos de abordagem do objeto, mas partes integrantes de uma dinâmica indissociável, do ponto de vista físico e social, que entendemos como paisagem.

Nossa postura em relação a paisagem não diz respeito ao entendimento preconceituoso dado ao campo de estudos da paisagem, não só pelo senso comum, mas em relação a muitos segmentos da academia, que associam diretamente os termos paisagem e paisagismo. 0 paisagismo também faz parte da categoria paisagem, mas possui um campo de entendimento mais facilmente delimitado à esfera do desenho da paisagem. Mesmo o termo paisagismo sofre um grau de preconceito, confundido muitas vezes com a atividade de jardinagem. A associação da paisagem a projetos de embelezamento urbano procura legitimar as estratégias de mercado adotadas no processo de reprodução das paisagens pós-modernas, afastando a categoria "paisagem" de sua importância como modelo explicativo das dinâmicas sociais e culturais envolvidas na reprodução do urbano. Da mesma forma que o ambiente natural colado ao conceito de sustentabilidade tem servido para separar o que é sustentável e o que não é, de acordo com representações ditadas pelo mesmo mercado.

Tomando a paisagem como processo de trabalho, dentro de sua polissemia conceitual e necessária interação interdisciplinar, a construção de uma paisagem não está necessariamente relacionada à construção física do espaço, mas a um conjunto de práticas, valores e percepções em relação ao espaço que podem, como desdobramento, alterar sua configuração física. Trata-se de um entendimento diverso do contido na maioria das intervenções paisagísticas promovidas nos centros urbanos, que consideram o projeto físico, apartado das dinâmicas sociais, como via preferencial de alteração da paisagem.

Considera-se que a questão não pode ser enfrentada a partir da aplicação da lei ou de uma abordagem que leve em 
conta somente os elementos naturais, atentando ao fato de que, sem a devida inserção social e apropriação do lugar por parte dos moradores, qualquer projeto de recuperação ambiental (stricto sensu) tem grandes chances de fracassar, do ponto de vista social e ambiental. Como forma de análise do contexto específico em que estamos inseridos, parte-se do princípio de que, da mesma forma que a paisagem moderna foi delimitada por meio de modelos artísticos, a paisagem contemporânea pode ser recriada ou reinventada a partir de novas relações de enfrentamento ou representações provenientes de diferentes áreas de conhecimento.

\subsection{MEDIAÇõES E REPRESENTAÇõES}

Em meio à extrema degradação, em que poderíamos enunciar a morte da paisagem, de acordo com sua concepção moderna ligada a representações de um ambiente natural idílico e belo, são colocados novos desafios, nos quais, nas palavras de Alan Roger, "não se trata de esconder o ferimento, nem de cicatrizar-lhe as bordas com curativos vegetais [...]. A nós compete, ao contrário, saber transformar esse ferimento em fisionomia e esta chaga em paisagem" (ROGER, 1999: 7). Em seu texto, Alan Roger cita as linhas férreas ou grandes vias expressas, marcas características da paisagem contemporânea, mas fica claro em relação às paisagens metropolitanas da periferia do capitalismo que as chagas da exclusão social, representadas pelas favelas, são paisagens a serem decifradas e incorporadas ao nosso imaginário urbano como paisagens e não como tipologias a serem exterminadas.

Tal imagem se mostra muito pertinente para o nosso entendimento, já que um dos desafios colocados é o reconhecimento da paisagem existente, em detrimento da visão estigmatizada em relação às favelas, de modo geral, sem que isso represente a legitimação da situação de precariedade colocada. Essas paisagens não devem ser colocadas como espaços segregados, mas como partes indissociáveis de uma mesma dinâmica de reprodução urbana.

Podemos reunir as representações em torno das favelas em dois grupos: as representações efetuadas de fora para dentro e de dentro para fora. No primeiro grupo, podemos citar: artistas urbanos que não fazem parte da realidade social local; acadêmicos que, em suas linhas de pesquisa, necessitam entender uma realidade diversa de seu contexto social; e diversas incursões de profissionais de diferentes áreas que tentam incorporar os signos da favela em suas atividades profissionais, como escritores, cineastas, atores e músicos. Tais incursões produzem representações, que se aproximam da realidade local ou não, mas que são incorporadas ao imaginário coletivo em torno da favela.

Outro conjunto de representações diz respeito ao que é produzido dentro das favelas, por seus moradores, onde se 
destacam, pelo menos até o momento, as representações musicais (o rap e o funk) e artísticas (coletivos urbanos e grupos de intervenção formados por moradores das periferias). Também devemos citar o fenômeno das pichações, que apesar da polêmica gerada, por não se tratarem de representações artísticas propriamente ditas (como o grafite), podem ser consideradas como importantes expressões de grupos sociais periféricos.

Não pretendemos desenvolver o vasto campo que envolve as representações em torno da favela, em que podemos citar, dentro do primeiro grupo, a obra de Paola Berenstein Jacques, que uniu as representações urbanas às artes plásticas, em seu livro Estética da Ginga, e representações urbanas à dança e outras áreas profissionais, em seu Maré Vida na Fave$1 a^{26}$, além dos conhecidos filmes produzidos nos últimos anos, que redefiniram o imaginário nacional a respeito das favelas.

Sobre as representações do cinema, vale citar o comentário de uma das lideranças do Jardim Jaqueline a respeito da imagem que o cinema e a televisão divulgam, que dão uma falsa impressão do que seria viver na favela. Os moradores do Jardim Jaqueline possuem uma forte preocupação com a identidade do favelado, ou morador de comunidade, como preferem se autorreferir. Afirmam que a mídia, por meio de filmes e novelas, além dos noticiários, perpetua imagens estéreis, que não se relacionam à vida dos moradores, reforçando o estigma da violência. Eles não se identificam com a maioria dos novos filmes que trazem a favela como cenário, sentindo-se ofendidos com a extrema violência difundida, como se a favela vivesse constantemente em função do medo e da violência. E o resto? E as pessoas comuns que vivem seu dia a dia?

Uma das lideranças locais lembra-se de um filme que não faz parte do repertório de filmes sobre favelas, com o qual se identifica, que se passa no Pelourinho, em Salvador (BA), sua cidade de origem²7.

Entendemos que as representações hegemônicas sobre a favela são determinantes em relação aos modelos de intervenção propostos. Seguindo a lógica da implantação das UPPs nas favelas cariocas, alguns projetos conhecidos partem do princípio de que a favela necessita de aberturas para circulação, com sua função implícita ligada à segurança pública, e de âncoras de visibilidade externa que possibilitem à gestão pública de plantão ser reconhecida pelo projeto em escala ampliada, visível pelos moradores de toda a cidade, do Brasil e quem sabe do cenário internacional. Está em voga a associação de projetos urbanos emblemáticos que resolvam as grandes mazelas urbanas, como violência e acessibilidade, a prefeitos e gestores públicos que passam a ser reconhecidos mundialmente, como o prefeito arquiteto de Curitiba, com seu projeto de transportes coletivos e o prefeito de Bogotá, com seu projeto em áreas tomadas pelo narcotráfico.

Tomando como referência uma intervenção executada pelo artista urbano português Vhils no Morro da Providên-
26 Em um dos capítulos do livro, "Falas da Maré", o médico Dráuzio Varella traça narrativas etnográficas das pequenas histórias reveladas pelos moradores. As narrativas confirmam que, apesar da violência e contingências locais, os moradores possuem um universo referencial muito superior aos estereótipos existentes.

27 A liderança se refere ao filme "Ó Pai Ó", de Monique Gardenberg, e à série televisiva homônima, com roteiro de Guel Arraes e Jorge Furtado e direção de Gardenberg, Mauro Lima, Carolina Jabor e Olívia Guimarães. Tais trabalhos seriam representações capazes de reproduzir um universo social peculiar, que diz respeito às dificuldades cotidianas, mas também à forma original com que os moradores conseguem encarar tais dificuldades. Certos trabalhos, que trazem grupos sociais à margem do poder econômico, mas que não possuem a favela como cenário, seriam mais coerentes em relação aos modos de vida dos moradores da favela que as representações que colocam a favela como protagonista.

28 Considerada oficialmente a primeira favela do Rio de Janeiro, o Morro da Providência, favela localizada nas imediações da estação de trem Central do Brasil, foi batizada no final do século 19 como Morro da Favela - daí também a origem do termo que se espalhou por outras comunidades carentes do Rio de Janeiro e do Brasil. Os primeiros moradores do Morro da Favela eram ex-combatentes da Guerra de Canudos e se fixaram no local por volta de 1897. 0 termo "favela" teria vindo de um morro de mesmo nome localizado em Canudos. 
$\operatorname{cia}^{28}$, no Rio de Janeiro, podemos analisar o impacto de uma ação que questiona o modelo de intervenção em favelas, que pode revelar conflitos atuais em relação às ações dessa natureza e conflitos anunciados. Em setembro e outubro de 2012, Vhils e sua equipe passaram um mês na Providência desenvolvendo um projeto artístico, que ouviu histórias do Morro e as imprimiu nas paredes que restaram das casas de moradores que haviam sido despejados pelo processo de urbanização em curso. Registrando, em meio às ruínas, os rostos de moradores que foram removidos de seus locais de moradia, entre eles velhos e crianças, o vídeo que relata a intervenção expõe as contradições existentes entre o discurso do poder público e fatos apontados pelos moradores. De acordo com depoimento de lideranças locais, o projeto de reabilitação de 131 milhões, inclui um teleférico, um plano inclinado e novas estradas, mas não resolve a questão de saneamento de toda a favela e não apresenta um projeto habitacional para o local, mas a remoção de um terço da comunidade. Os moradores relatam que não será construída uma única unidade habitacional no interior da favela, mas em um conjunto habitacional localizado em terreno fora da área de intervenção, representando a perda de identidade em relação ao lugar. Serão removidas 832 casas da favela, que recentemente foi pacificada com a implantação de uma UPP.

O que nos mostram as atuais ações em curso? Como a segurança militarizada aliada a projetos de grande visibilidade como o da Providência e anteriormente do Morro do Alemão - que também contou com a implantação de um teleférico, que já figurou em diversos meios de comunicação, inclusive em uma novela - são aceitos fora dos espaços da favela como boas referências de inclusão dos moradores de baixa renda. Mas o que os moradores locais pensam a respeito?

Em São Paulo, estamos vivenciando exemplos semelhantes, que dispensam o teleférico por uma questão topográfica, mas que se utilizam de referenciais urbanos fortes e de bons exemplos arquitetônicos com o discurso de
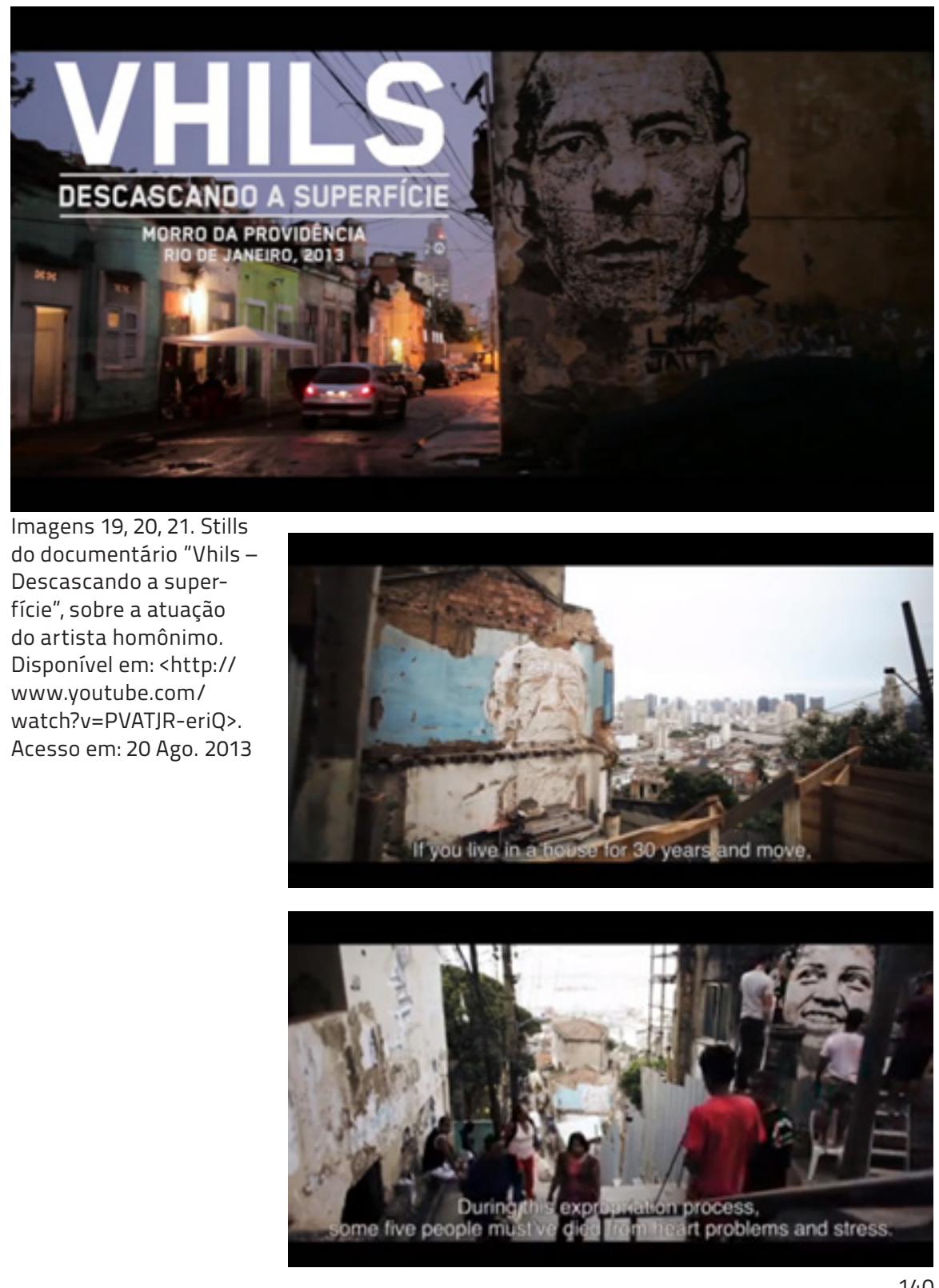
que "todos têm direito a bons projetos". Obviamente concordamos com isso, mas será que as soluções necessárias para melhorar a qualidade de vida dos moradores de favelas não demandariam apelos imagéticos tão fortes? Portanto não seriam tão emblemáticos para gestores públicos que precisam divulgar seus feitos via referenciais impactantes? Seria o "retorno positivo da imagem" aos governantes, anunciado por Marilena Chauí (2006: 120), a respeito da visão contemporânea em torno do patrimônio cultural e ambiental, capturado como fonte de poder para o Estado-nação e considerado como questão econômica e política de marketing?

Os últimos projetos habitacionais e de urbanização de favelas conhecidos em São Paulo ganharam diversos prêmios nacionais e internacionais de arquitetura, além de diversas publicações patrocinadas pela prefeitura municipal. Os projetos para o Conjunto Habitacional Nova Paraisópolis, de urbanização da favela Cantinho do Céu e do condomínio projetado pelo arquiteto Ruy Ohtake em Heliópolis, tiveram amplo reconhecimento da mídia, como parte de um conjunto de iniciativas da Secretaria de Habitação do Município de São Paulo de mudança de paradigmas em relação à habitação de interesse social. Os projetos reuniram diversos prêmios: um destaque na Bienal Internacional de Arquitetura de Roterdã (Holanda), em 2009, e o $1^{\circ}$ lugar na categoria Habitat Social y Desarrollo Urbano na XVII Bienal Panamericana de arquitetura de Quito, em 2010, para o projeto de Paraisópolis; UN-Habitat Scroll of Honour Award, 2012, Prix d`Excellence Awards, 2010, Fiabci Internacional, categoria Infraestrutura Pública, Master Imobiliário, 2009, Fiabci Brasil e Secovi, categoria Profissionais Ação Social, para os projetos de regularização fundiária. Também podemos citar o início da era dos selos verdes, empregados também em projetos de habitação social29.

Tais projetos representaram uma mudança de postura em relação à idealização de projetos de habitação de interesse social, sendo devidamente re-
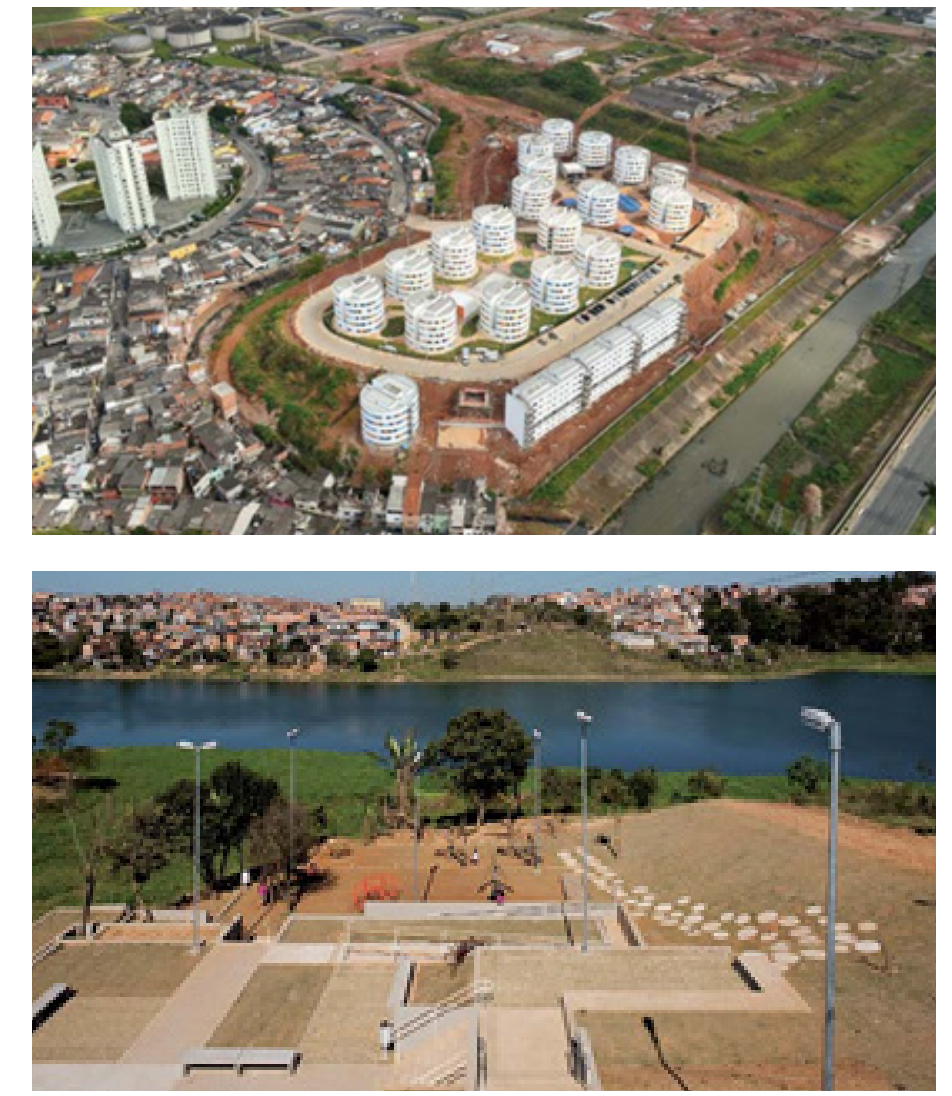

Imagens 22, 23. Imagens do conjunto habitacional desenhado pelo arquiteto Ruy Ohtake em Heliópolis e do projeto do Cantinho do Céu, reconhecido internacionalmente. Fonte: <http://www.arcoweb.com. br/arquitetura/ruy-ohtake-centro-educativo-cultural-condominio-

-residencial-heliopolis-04-04-2012.html> e <http://www.belasartes.br/ chocolatedigital/noticias/projeto-de-urbanizacao-no-cantinho-do-ceu-destaque-na-bienal-de-veneza> 
conhecidos pela sua inserção paradigmática dentro de um modelo de produção em que se destacam a baixa qualidade arquitetônica e a monotonia dada pela repetição em série, mas decididamente não conseguiram se afirmar como política pública na área de habitação de baixa renda, sendo preocupante o número de remoções engendradas por tais projetos, em detrimento da construção de novas unidades habitacionais. Os números podem ser vistos na pesquisa realizada pelo Observatório de Remoções da FAU-USP ${ }^{30}$. Podemos reconhecer em todos esses projetos um dado que os une, que é a emergência do novo. Todos os exemplos que "saem bem na foto" se relacionam ao novo, à ocupação de terrenos vazios ou à visibilidade de um espaço coletivo independente do emaranhado de casas que caracterizam a favela. Os belos conjuntos habitacionais, ainda com influências do Movimento Moderno, ainda não podem ter resquícios de cidade que os possam comprometer.

Importante, nesse momento, comparar os atuais exemplos de intervenção em favelas - com produção de novas unidades habitacionais - e a produção anterior conhecida, por meio de diversos trabalhos acadêmicos até os anos $2000^{31}$, que nos revelam maior proximidade com as ruas, onde o desenvolvimento teórico e acadêmico, aliado à real intervenção nesses espaços, mostra um universo referencial que une projeto e seus habitantes, com forte viés participativo, no qual "o processo de elaboração do projeto e de execução das obras é também parte do processo de construção da cidadania da população moradora em favelas" (BUENO, 2000: 317). Tal discussão merece um maior desenvolvimento, principalmente em relação a uma investigação mais detalhada do processo de pós-ocupação de projetos de intervenção mais comprometidos com uma estrutura física e social preexistente e os modelos atuais de intervenção, cujos ícones são autossuficientes em relação ao contexto em que se procura intervir.

Detemo-nos aqui em exemplos de olhares de fora para dentro, devido

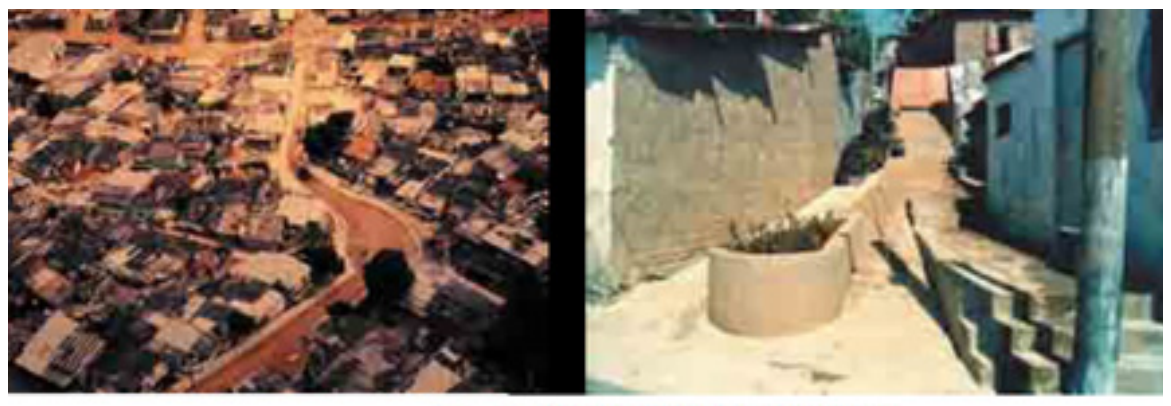

Figura 3 . NOSSA SENHORA APARECIDA.

Figura $\exists$. . zona leste, vista aérea da urbanizaça na ruas quadra apos as obras

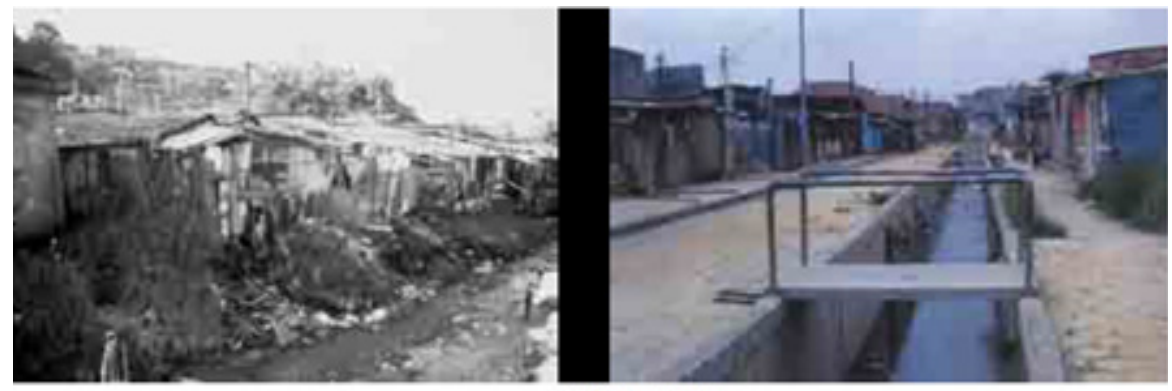

Figura 3.8 miranguaba

Imagens 24, 25. Imagens extraídas da tese de Laura Machado Mello Bueno (2000)

29 Disponivel em: <www.habisp.inf.br/ pagina/b64h25_programa-de-urbanizacao-de-favelas-de-sao-paulo-ganha-premio-das-nacoes-unidas>. Acesso em: 10 Ago. 2013

30 Disponível em: <http://observatorioderemocoes.blogspot.com.br/>. Acesso em: 10 Ago. 2013.

31 Cf. BUENO, 2000 
à complexidade de abordagem das ações endógenas que vêm ocorrendo nas favelas e periferias em geral. Deixamos essa complexa tarefa aos coletivos que vêm se consolidando nas periferias, aos seus estudiosos e aos trabalhos que tratam especificamente dessas representações nas áreas da filosofia, sociologia e, principalmente, da antropologia urbana.

Em que medida nossa construção de paisagem, especificamente da favela, ainda está ligada a uma invenção da modernidade, que vem sendo apropriada como objeto de consumo ou suporte físico esvaziado de significados? Discutir paisagem pressupõe, antes de tudo, a discussão de valores, que envolvem todo um processo pedagógico, com a construção de referenciais e de novas representações, dentro de um conjunto de valores compartilhados coletivamente. Como podemos tomar as rédeas dessa construção em curso, atribuindo significado e valor a um termo que vem se esvaziando e se relativizando em torno de uma multiplicidade de conceitos e práticas, úteis à apropriação econômica? Como a percepção depende de diferentes condições de acesso em relação ao espaço e suas temporalidades, as construções possíveis dependem de um ponto de vista construído de acordo com a ampliação das condições de acesso a um mundo sensivel. A percepção da paisagem deve se estabelecer no dia a dia de quem a pratica, por meio de processo contínuo de aprendizado, dentro de uma construção necessariamente coletiva.

Dessa forma, nossa paisagem não é formada somente pelo emaranhado de construções sem uma ordem aparente, por onde correm o esgoto e a violência urbana, mas por um universo compartilhado por moradores com diferentes histórias e com diversos graus de envolvimento com os ditos "agenciamentos da vida cotidiana". Uma paisagem que sofre com a ausência de intervenções efetivas do poder público, mas que pode sofrer ainda mais, de acordo com a natureza do projeto a ser realizado.

A intervenção na paisagem é efetiva quando se alteram práticas em relação ao lugar ou quando simplesmente se diz algo sobre aquela paisagem que não seria reconhecido sem uma alteração de ponto de vista. Dessa forma, novas mediações funcionam como ativadoras de uma relação inexistente ou debilitada entre observadores e meio, em cenários em que poderíamos reconhecer a ausência da paisagem. Um discurso sobre a paisagem no urbano não passa somente pela estrutura física do espaço, mas igualmente pelo respeito às relações nele estabelecidas. 0 entendimento da paisagem deve partir dos observadores que a animam e participam ativamente de sua configuração e das dimensões discursivas que envolvem sua prática.

Não se trata de defender e perpetuar o precário, mas de uma constatação de que o entendimento da paisagem não leva à destruição total de ambientes degradados, mas a um processo de transformação da paisagem - onde houver a des- 
truição física de um local, ela será consentida pelas pessoas diretamente afetadas - e não uma ação arbitrária e violenta, como vem ocorrendo tradicionalmente.

\section{O PRINCÍPIO PEDAGÓGICO OU O PROCESSO DE EMERGÊNCIA DA PAISAGEM}

Primeiramente devemos deixar claro que a "natureza natural" e a "natureza percebida" não se excluem. O processo de entendimento da paisagem pela esfera da cultura e em relação a um contexto situado não exclui a dimensão física da natureza, com seus elementos físicos determinantes, que acreditamos ser de extrema importância para o entendimento do conjunto. Não é o foco desta dissertação a identificação das diversas funções das Áreas de Preservação Permanentes (APPs) urbanas e os reais danos causados por seu processo de ocupação pela dinâmica urbana, mas desconstruir os diversos juízos de valor, que diferenciam o que seriam os processos de degradação socialmente aceitos e quais parcelas da população seriam criminalizadas nesse contexto.

Nosso objetivo não é resgatar uma relação com a natureza, perdida com o advento do período industrial, no sentido de retornar a um modo de vida rural e diretamente ligado à terra, ou um resgate do modo de construir vernacular, coerente em relação a um determinado contexto histórico, com suas limitações físicas e tecnológicas. O objetivo é entender que as atuais escolhas em relação ao ambiente construído não representaram um processo de valorização do homem, tampouco da natureza. Nossas escolhas, pautadas pelo capital, não proporcionaram a valorização da qualidade de vida nas cidades, nem a liberdade de seus moradores - não mais vítimas da natureza, como no mundo medieval, mas vítimas de um modo de vida extremamente financeirizado, que determina nossos modos de vida, nossa relação com a cidade e com a natureza.

Acreditamos que, para inserir a problemática dos recursos naturais e a importância da preservação ambiental no universo referencial dos moradores da favela, devemos concomitantemente trabalhar as dimensões políticas envolvidas nessa consciência ambiental. Inserir os moradores dentro de um discurso ambiental pronto para consumo - no qual a questão do lixo, juntamente com a responsabilidade dos moradores em sua geração, é colocada como carro-chefe desse discurso - pode representar a manutenção da favela na mesma ordem de reprodução das relações sociais. A questão da reciclagem é um bom exemplo de estrutura de dominação imposta de cima para baixo, mas existem outras, como a ocupação das margens dos córregos, como foi discutido no processo de ocupação do Jardim Jaqueline.

Seria parcial e inverídico colocar aos moradores do Jardim Jaqueline que eles são os responsáveis pela degradação e poluição dos cursos d'água locais, pelas razões já expostas ao longo da dissertação, mas é necessário colocar aos moradores 
da favela, aos moradores do condomínio e aos frequentadores do Shopping as reais dimensões das formas de apropriação do espaço no entorno dessa microbacia específica, com suas reais implicações ambientais decorrentes. Nossa postura não legitima o processo de ocupação das APPs, pelo contrário. Desconstruindo a lógica ideológica que cria uma postura omissa em relação à cidade legal e criminaliza a população de baixa renda que ocupa os espaços mais inadequados das grandes cidades, deixamos clara a atitude a ser tomada: desobstruir a maior parte possivel das APPs, para que elas cumpram sua função ambiental e social, proporcionando espaços de fruição para a coletividade, considerando as particularidades dos contextos de adensamento existentes, e lutar pelos espaços adequados à ocupação restantes na cidade. Em nosso caso específico, os espaços vazios saltam aos olhos de quem simplesmente analisa uma imagem aérea.

Estamos falando em um real processo de ampliação de cidadania, tão difundido em inúmeras dissertações e teses oriundas do meio acadêmico. E é sobre esse processo que devemos nos debruçar, considerando a pequena parcela que cabe à nossa área de atuação para o equacionamento da chamada questão urbana ou quem sabe da questão ambiental.

A qualidade do espaço construído inevitavelmente influencia a qualidade das interações sociais que lá acontecem. Ela não as determina completamente, já que há sempre lugar para diversas e algumas vezes subversivas apropriações de espaços, e para a organização de ações sociais que contestam aquelas moldadas por práticas espaciais (CALDEIRA, 2000: 302)

Acreditamos que o projeto tem o seu papel na definição de novas qualidades de vida e apropriação de um ambiente socialmente equilibrado, mas fica claro, pelo processo de pesquisa apresentado o fundamental papel da política nestas determinações, e principalmente como ela se dá no dia a dia dos moradores.

\subsection{O PRINCÍPIO DE AMPLIAÇÃO DA CIDADANIA}

Uma ideologia não possui um poder absoluto que não possa ser quebrado ou destruído. Quando uma classe social compreende sua própria realidade, pode organizar-se para quebrar uma ideologia e transformar a sociedade.

Marilena Chauí 
Assim como foram apresentadas estruturas de poder e dominação, que paralisam a ação radical sobre a paisagem, acreditamos que os caminhos para a radicalidade são cada vez mais necessários e que os potenciais atores de mudanças são os moradores dos espaços segregados da cidade, aliados à mudança de paradigma em relação às posturas oficiais, com o devido tensionamento do Estado, a fim de desestabilizar as relações de dominação vigentes e buscando a aproximação entre a cidade legal e a cidade real. Enquanto a população marginalizada não lutar pelo direito à habitação, acompanhada de espaços de lazer, cultura, ou de simples contemplação, desvinculados da lógica do capital e atendendo às reais demandas presentes na cidade, os mecanismos indutores do processo de segregação não serão tensionados.

Como diz Francisco de Oliveira, a cidadania é um conceito que, aplicado, pode criar, manter e ampliar direitos, não sendo o corpo estático ditado pelas teorias de "pertencimento universal". A aplicação do conceito de cidadania tem em vista um trabalho permanente de criação, recriação, de invenção e reinvenção de instituições através das quais o cidadão exerce sua autonomia. Com esse processo de entendimento não cabem posturas assistencialistas em relação à população marginalizada, assim como não cabem soluções paliativas em relação à sua inserção na cidade. Não se trata de garantir o direito de moradores de permanecerem em áreas ambientalmente frágeis, enquanto os melhores espaços estão ocupados pela população de maior poder aquisitivo ou permanecem vazias aguardando valorização. O objetivo não deve ser a garantia do direito da população pobre da cidade de usufruir dos restos deixados pelo sistema produtivo, vivendo permanentemente em meio ao precário. Em um momento em que o capital disputa, palmo a palmo, os espaços da cidade, torna-se cada vez mais urgente a necessidade não somente de se discutir o conceito de paisagem e sua ampliação, relativo aos espaços públicos e às condições materiais de sua disputa, mas ampliar o jogo político que permita sua efetivação.

O processo de formação para a ampliação da cidadania é longo, tendo enfrentado, no Brasil, todo um histórico político de segregação e anulação da fala das "minorias", e esse tempo de formação se choca com as temporalidades cada vez mais dinâmicas do capital. "A privatização do público é uma falsa consciência da desnecessidade do público" (OLIVEIRA, 2001: 68). De acordo com as formas aparentes de que a burguesia revestiu o Estado, esse não faz sentido se não for uma extensão do privado.

Esses mecanismos de disputa por espaços de poder, que coptam o público em nome de interesses privados, afetam e são afetados pelas políticas de reconhecimento aplicadas às classes subalternas. Vera Pallamin desenvolve o conceito do reconhecimento - ou "política do reconhecimento" -, à luz das conceituações propostas pelos filósofos Charles Taylor, Habermas e Axel Honneth. A propósito da ausência de reconhecimento moral e material à parcela "dos que não contam", a 
arquiteta e filósofa, discute os caminhos para emancipação e luta pelo reconhecimento das parcelas da população organizadas. No âmbito da reflexão teórica, a expressão "política do reconhecimento", Charles Taylor afirma que:

nossa identidade é moldada em parte pelo reconhecimento ou por sua ausência, frequentemente pelo reconhecimento 'errôneo' por parte dos outros, de modo que uma pessoa ou grupo de pessoas pode sofrer reais danos, uma real distorção, se as pessoas ou sociedades ao redor deles lhes devolverem um quadro de si mesmos redutor, desmerecedor ou desprezível. 0 não reconhecimento ou o reconhecimento errôneo pode causar danos, pode ser uma forma de opressão, aprisionando alguém numa modalidade de ser falsa, distorcida e redutora. [...] 0 devido reconhecimento não é uma mera cortesia que devemos conceder às pessoas. É uma necessidade humana vital (PALLAMIN, 2005).

Ao largo da complexidade que envolve o conceito de reconhecimento ${ }^{32}$, que é devidamente trabalhado pela pesquisadora, consideramos aqui algumas questões relevantes para o nosso desenvolvimento, como a necessária diferenciação entre os conceitos de reconhecimento e de redistribuição - um de caráter moral, outro ligado à ordem econômica -, que se relaciona à redistribuição igualitária dos recursos materiais disponíveis. As duas vias estão ligadas à busca por emancipação, em que os conflitos de ordem redistributiva e por reconhecimento se complementam. Assim como a pesquisadora identificou as relações entre tais conflitos na conhecida ocupação Prestes Maia ${ }^{33}$, podemos identificar tal tensão no Jardim Jaqueline, onde a demanda principal apresentada é de ordem material, representada pelo título de propriedade derivado do processo de regularização fundiária, mas onde as questões de ordem moral são prementes, não somente em relação ao reconhecimento do direito à cidade, que também está colocado na questão da regularização fundiária, mas principalmente no discurso diário dos moradores, que se colocam constantemente contra os estigmas sociais depositados na favela.

Boaventura Sousa Santos não acredita em uma emancipação de classes ${ }^{34}$, dada a integração política, social e cultural do operariado na reprodução do capitalismo, mas acredita em uma emancipação do indivíduo e da sua subjetividade. Apesar de partilhar com Foucault o entendimento de que os indivíduos estariam fortemente oprimidos pelos poderes-saberes das disciplinas e normalização social, fato que tornaria inviável a emancipação do indivíduo, o autor acredita que o processo histórico da cidadania e o processo histórico da subjetividade são autônomos, ainda que relacionados. Essa premissa leva à possibilidade de novas formas de cidadania - coletivas e não individuais, menos baseadas nos direitos e deveres e mais em formas e critérios de participação - nas quais seria possível uma relação mais equilibrada com a subjetividade (SANTOS,
32 Examinando as falhas de reconhecimento que levam aos conflitos, o filósofo Axel Honneth propõe a consideração de três niveis de desrespeito, diretamente relacionados àqueles do reconhecimento: o desrespeito do corpo, que é o modo mais elementar e mais devastador de todos, levando ao definhamento psíquico; o desrespeito dos direitos, que alija os sujeitos de suas prerrogativas jurídicas que subsidiam sua interação social, levando ao rebaixamento moral. e desrespeito da estima social, que rebaixa o valor social de grupos ou indivíduos, promovendo a vergonha social ou vexação. Nesse entendimento, é importante ressaltar a afirmação do filósofo de que o desrespeito por si só não leva à luta. 0 discernimento moral é essencial para que haja a resistência - a humilhação aí pode atuar como uma "mola propulsora" -, mas é preciso que haja um meio socia e político favorável a isso (PALLAMN, 2012: 62).

330 Edifício Prestes Maia foi ocupado no período de 2002 a 2007 por integrantes do Movimento dos Sem-Teto do Centro (MSTC) e voltou a ser ocupado em outubro de 2010. É considerada a maior ocupação vertical da América Latina.

340 autor é crítico em relação à validade do conceito de luta de classes em nosso contexto histórico. De acordo com Santos, por mais que essa categoria tenha representado uma ferramenta importante para a sociologia, colocá-la nos tempos de hoje como a principal categoria analítica significaria desprezar todas as outras formas de manifestação das relações sociais, inclusive nas diversas facetas que a dominação e [...] 
2010: 247). A possibilidade de emancipação colocada pela modernidade estaria representada pelos novos movimentos sociais, que souberam identificar essas novas formas de opressão além das relações de produção, buscando um novo paradigma social menos ligado à riqueza e ao bem estar material e mais baseado na cultura e na qualidade de vida. Nessa seara, o autor acredita que o cotidiano, que representa o mundo da intersubjetividade, seja a dimensão espaçotemporal da vivência dos excessos de regulação e das opressões concretas em que eles se desdobram. Sempre pensando na inter-relação entre as escalas local e global, o cotidiano é visto como campo privilegiado de luta, em que o senso comum e o dia a dia vulgar, tanto público como privado, desvulgarizam-se e passam a ser oportunidades únicas de investimento e protagonismo social (SANTOS, 2010: 261).

O autor diferencia os novos movimentos sociais como movimentos de ampliação da subjetividade (democracia participativa) em detrimento da cidadania tal como conhecemos (democracia representativa). As formas de opressão e de exclusão contra as quais lutam não podem, em geral, ser abolidas com a mera concessão de direitos abstratos e universais, como é típico da cidadania.

Dentro de nosso contexto, em que as conquistas materiais estão diretamente atreladas ao jogo da democracia representativa, não podemos falar em real emancipação sem tocar nessa ferida. Ao mesmo tempo entendemos que tais mecanismos de ampliação das subjetividades coletivas são caminhos preferenciais para a conquista de nosso objetivo, que é a ampliação de direitos sobre a cidade, representada em nosso trabalho pela disputa pela paisagem urbana.

É óbvio que as diversas organizações sociais presentes nas favelas não podem ser consideradas dentro de uma matriz organizacional tão refinada quanto os movimentos sociais citados por Boaventura Sousa Santos, como os movimentos ambientais ou feministas ou movimentos da América Latina, como o Movimento dos Trabalhadores Sem Terra (MST). Mas a relação entre organização local e possível rebatimento regional ou global, possível em articulações mais amplas, como o Movimento de Moradia de São Paulo, são potencialidades desses movimentos que não devem ser subestimadas. Mesmo não articulados a movimentos maiores, as lideranças locais do Jardim Jaqueline, que representam demandas muitas vezes básicas e imediatas, como infraestrutura, e inseridas dentro da lógica democrática liberal, que utiliza intensamente o voto como moeda de troca, podem representar um campo fértil para novas reivindicações, de ordem emancipatória.

Nesse sentido, concordamos que "politizar significa identificar relações de poder e imaginar formas práticas de as transformar em relações de autoridade partilhada" (SANTOS, 2010: 271) e consideramos que quando identificamos as relações de poder expressas na paisagem contribuímos para a politização dos moradores inseridos no "lado mais fraco da
[...] a opressão existem, como a de gênero, a racial, a familiar. Apesar de concordarem com as peculiaridades de nosso tempo histórico, estudiosos de Marx apontam equívocos em relação à sua interpretação a respeito da categoria classe social, que, desvinculada do conceito de centralidade do trabalho, em sua dimensão ontológica, de acordo com entendimento de Lukács, traria desenvolvimentos contraditórios em relação à ideia de luta de classes. Para o entendimento desses embates entre o autor e teóricos marxistas ver: Desdobramentos da concepção de Boaventura de Sousa Santos sobre a teoria marxiana em seu projeto de emancipação social, de Rodrigo Bischoff Belli, e Boaventura de Sousa Santos e a 'pós-modernidade de contestação", de Maurício de Bernardino Gonçalves. Disponivel em: <http://www2. marilia.unesp.br/revistas/index.php/ aurora/article/view/1265/1125>. Acesso em: 27 Jan. 2014. 
corda". Nossa utopia da paisagem diz respeito a um universo de pertencimento que liberta e não aprisiona. Temos responsabilidades e compromissos na construção dessa utopia. O grande desafio é unir os diferentes grupos sociais hoje desunidos pela segregação socioeconômica, pensando em nossa área de atuação, que é a paisagem. Como incluir parcelas da cidade segregadas e principalmente estigmatizadas como redutos de violência e precariedade social? A partir desse entendimento, resta a vontade de partir de um conjunto de referenciais técnicos disponíveis, em um trabalho articulado com os moradores locais, e transformá-los em instrumentos efetivos de ampliação da cidadania, com o partilhamento do conhecimento coletivo necessário ao reconhecimento de todos os direitos envolvidos nessa conquista, dentre eles o direito à paisagem.

Se a casa está ligada a uma posição social e ao mundo interior de seu habitante, a paisagem diz respeito a uma relação de pertencimento em relação a uma natureza estrategicamente afastada pelo sistema de produção e a um contexto sociocultural que deve ser constantemente ativado. Estamos falando de dois momentos relativos à paisagem: o de reconhecimento, necessário em um cenário em que se elegem as paisagens de distinção, em detrimento das paisagens vivenciadas; e o de luta pela paisagem, que seria a ação sobre a paisagem desejada e não a relação de passividade frente aos referenciais impostos. 


\section{CONSTRUÇÃO DE RESULTADOS E DESAFIOS COLOCADOS}

Iniciamos essa investigação com hipóteses que nortearam nossos partidos de pesquisa e configuraram um campo referencial que, não esgotando as possibilidades em relação ao objeto, deixa clara uma posição ou um caminho de enfrentamento de um tema tão caro aos arquitetos-urbanistas. A impossibilidade da independência de abordagens, sejam elas de natureza física, social ou econômica, é uma premissa básica para quem deseja entender a dinâmica de uma favela, seja qual for a área de conhecimento em que se situa o pesquisador. Reconhecemos que a abordagem multidisciplinar traz o risco da indefinição metodológica e da imprecisão conceitual, por parte de um pesquisador formado em uma área específica que se aventura em outras searas do conhecimento. Porém avaliamos que o olhar tecnicista - ou o discurso competente, nas palavras de Marilena Chauí, que poderia trazer uma abordagem meramente quantitativa, com referenciais ligados a densidades, potenciais construtivos, metragens ligadas às áreas de preservação, riscos geológicos - traz falsas certezas e seguras definições, socialmente valorizadas em nosso contexto econômico, mas inertes em relação ao real entendimento de nossa paisagem situada.

Outra hipótese inicialmente levantada pela pesquisa diz respeito à especificidade dos locais estudados. Apesar das teorias e estudos que tratam da evolução dos espaços de baixa renda nas grandes cidades brasileiras, com o peso determinante da estrutura econômica nessa dinâmica, o olhar situado em relação ao objeto revela outras abordagens possíveis e novos métodos de investigação. O emprego da pesquisa qualitativa, mesmo não estando consolidado em nossa área de concentração, se mostra fundamental para o aprofundamento de questões em que as estatísticas indicam uma visão totalizante, em que a paisagem não é revelada.

Apesar da relação de necessidades apresentada pelos moradores, vinculada a um contexto comum a todas as áreas que expandiram à margem do crescimento econômico, ou em função dele, grande parte dos moradores do Jardim Jaqueline aponta como prioridade a regularização fundiária da favela. A prioridade da regularização em detrimento da solução da precariedade encontrada na favela quanto a rede de esgoto, áreas nas margens dos córregos e áreas que necessitam de intervenção urgente do poder público, indica o papel central da questão fundiária na disputa pela cidade, mas também revela os valores que são negligenciados em nome desse forte referencial ligado ao poder econômico, que baliza as relações de cidadania nas cidades. A prioridade hegemônica de nossa sociedade, derivada da "estratégia simbólica do capitalismo transnacional de integrar na lógica do consumo todas as classes sociais", nas palavras de Boaventura Sousa Santos (2010: 
275), escamoteia as necessidades básicas dos moradores das grandes cidades, que se relacionam ao saneamento básico, educação e saúde de qualidade, mobilidade urbana, lazer e recreação e - por que não? - contemplação, relacionadas aos espaços coletivos.

Quanto os cursos d'água, a partir do momento em que a favela se apropriou de seus leitos, eles passaram a ser invisíveis. Talvez menos invisíveis que suas nascentes, completamente aterradas e canalizadas pelo Shopping Center. Nesse momento, entendemos o significado positivo atribuído pelos moradores da favela ao processo de ocultamento do córrego, visto como fator de insegurança, insalubridade e precariedade. De fato, em meio a um contexto social em que a questão do saneamento básico ainda está longe de ser equacionada e o histórico de intervenção em favelas mostra o tamponamento dos cursos d'água como solução adequada, não podemos culpar o imaginário coletivo local, repleto de maus exemplos.

Nesse sentido, valem projetos de intervenção de qualidade, com seu potencial referencial e didático inerentes, mas colocados de forma participativa, a fim de evitar representações que não dizem respeito a realidades locais, sem potencial de apropriação. Por que equipamentos considerados de primeira necessidade, como postos de saúde ou escolas, e de utilidade específica, como os campos de futebol, aparecem como prioritários, em detrimento de espaços culturais, praças e espaços livres, dentro de uma concepção ampliada em relação à paisagem? Se a resposta parece óbvia, a atuação necessária sobre tal realidade não está clara nos meios técnicos e acadêmicos.

Temos a clareza de que nossas necessidades em relação à natureza - e em relação à paisagem - não se restringem à dimensão física da natureza, representada pela qualidade ambiental, mas também se relacionam à nossa inserção social na paisagem, com seu universo de significados e percepções. Porém, tal constatação não pode levar ao entendimento de que a paisagem pode ser negligenciada em nome das necessidades sociais urgentes que nos são impostas. Expomos nos capítulos apresentados que nossa negligência em relação à paisagem não se relaciona às diversas formas de utilização do território por parte das diferentes classes sociais, mas a uma forma peculiar de crescimento urbano que espolia o meio ambiente, relaciona as diversas classes e cria discursos ideológicos para responsabilizar os menos favorecidos.

Nosso processo de construção da paisagem sofre com a hegemonia de referenciais culturais fortes, por parte de todas as classes sociais. Se podemos afirmar que a paisagem é inviabilizada em meio a um contexto de precariedade que impede a emergência das dimensões sensiveis do conhecimento, em relação às ocupações das populações de baixa renda, também podemos considerar que as formas de produção do ambiente construído por parte de uma classe média que possui novos hábitos e formas de apropriação urbana também é incapaz de criar paisagens qualificadas. Essa discussão abrange a 
paisagem física, mais facilmente identificável em uma análise superficial, e a paisagem referencial, que é o que chamamos de relação situada dos moradores na cidade. Como nossa condição urbana situada "não se relaciona somente com o da porta para dentro, mas também com o da porta para fora" estamos perdendo nossa capacidade de se relacionar com uma paisagem ampliada, que diz respeito à nossa vivência nos espaços coletivos.

Quais são as determinações de nosso tempo histórico que influenciam na construção de nossas paisagens contemporâneas? Temos representações marcantes que nos dão a medida de cada tempo histórico, desde Robert Smithson, que vislumbrou toda a tragédia da revolução industrial em uma pequena cidade perdida ao longo do Rio Passaic, até o exemplo recente de uma série de fotografias que mostram as ruínas de um ideal urbanístico em decadência35. 0 que falar da destruição do capital expressa em nossas paisagens urbanas contemporâneas? Serão os condomínios fechados as ruínas do futuro? Como coloca Sharon Zukin (2000: 85), a arquitetura é importante porque é o símbolo do capitalismo ou porque é o capital do simbolismo?

A construção social da paisagem urbana combina poder econômico, político e legitimação cultural. Dentro dessa construção social, temos a clareza de que o que deve ser eliminado nas favelas é o seu contexto de precariedade e não a sua paisagem, representada pelo seu tecido urbano e relações sociais estabelecidas. E, nessa esteira, mostra-se importante a diferenciação entre o processo de enobrecimento, de viés econômico, decorrente de estratégias de valorização física do espaço, com sua inserção dentro de uma lógica especulativa, e formas de valorização que passem pelo reconhecimento dos moradores, em sua dimensão moral, dentro da conceituação estudada por Vera Pallamin.

A constatação de que os referenciais culturais ligados ao consumo e à financeirização da vida atingem todas as classes sociais não pretende culpar as populações mais pobres por fazer parte da mesma matriz referencial das classes mais favorecidas, pelo contrário, busca problematizar os dispositivos que levam às atuais conformações urbanas, ligadas aos processos de enclausuramento, apartamento social e disputa por mecanismos de diferenciação social, que podemos chamar de disputas pela paisagem.

Estamos tratando de realidades urbanas em mutação, em que os parâmetros analisados de hoje podem ser diferentes em um curto espaço de tempo. Intervir em favelas atualmente implica considerar desafios que não faziam parte do universo referencial de urbanização de favelas há 20 anos. Se os recursos técnicos se desenvolveram e hoje possuímos importantes exemplos a serem considerados, o substrato social não é passível de generalizações, sendo cada vez mais importante a intervenção de equipes multidisciplinares capacitadas para o enfrentamento dos "equilíbrios instáveis" que
350 fotógrafo Kevin Bauman registrou cem casas e mansões em ruínas, no bairro de Brush Park, subúrbio de Detroit (EUA), cidade ícone da indústria automobilistica, que passa por crise econômica. Disponivel em: <http://www.kevinbauman.com/projects/100_abandoned_ houses>. Acesso em: 27 Jan. 2014. 
estruturam a cidade real. Em relação à nossa abordagem, via paisagem, entendemos que não basta inserir autoritariamente novos repertórios paisagísticos, ligados à preocupação com o meio ambiente, sem tocar na ferida de "quem é quem" na história da degradação de nossas grandes cidades. Fazer parques lineares sobre os pobres e ignorar os danos causados pelas classes dominantes faz parte da estratégia de grupos sociais hegemônicos pela disputa pelo espaço e pelos referenciais expressos na paisagem.

Defendemos a preservação dos cursos d'água, a coexistência entre moradias e meio ambiente, respeitando as dinâmicas naturais do meio físico, mas sem hipocrisias. Não podemos aceitar que a população de baixa renda viva nas áreas mais vulneráveis da cidade. As áreas ambientalmente frágeis não devem ser defendidas como espaços preferenciais às ocupações de baixa renda. Acreditamos que os cursos d'água do local devem ser incorporados às formas de vida dos moradores, mas que seu resgate deve ser feito de forma radical, desde sua nascente.

Como elaborar projetos hipócritas que removem cidadãos desprovidos de poder econômico e fazem vista grossa às degradações "institucionalizadas"? Qual gestor teria a coragem necessária para resgatar essa porção da Bacia do Pirajussara, da forma como deveria ser feito do ponto de vista ambiental, implodindo o estacionamento do Shopping e parte da área construída do condomínio residencial? Se é possível avaliar a conveniência e a pertinência de uma ação radical de intervenção no espaço em relação à cidade legal, por que tal ponderação não é possível quando se trata da população fragilizada? Se ninguém pensaria em uma solução radical em relação à cidade formal então é coerente se pensar em uma solução menos impactante para os moradores da favela, na mesma medida.

Defendemos aqui a real paisagem a ser resgatada dentro de nosso contexto contemporâneo, que é a paisagem que engloba o pertencimento e o reconhecimento (identidade) em relação ao que convencionamos chamar de natureza (natural). Se a natureza precisa ser incorporada à cidade, essa natureza deve vir em sua real dimensão, que considera o fator humano em suas determinações. Dessa forma poderemos falar em paisagens urbanas contemporâneas, como parte de um todo devidamente problematizado. 


\section{BIBLIOGRAFIA}

ABRAMO, Pedro. Favela e Mercado Informal: A nova porta de entrada dos pobres nas cidades brasileiras. Rio de Janeiro: IPPUR-UFRJ, 2010.

BRASIL. MINISTÉRIO DAS CIDADES. Regularização Fundiária Urbana: como aplicar a Lei Federal n 11.977/2009. Ministério das Cidades, Secretaria Nacional de Habitação e Secretaria Nacional de Programas Urbanos. Brasília, 2010.

BRITO, Felipe; OLIVEIRA, Pedro Rocha de. Até o último homem: Visões cariocas da administração armada da vida social. São Paulo: Boitempo Editorial, 2013.

BUENO, Laura Machado Mello. Projeto e Favela: Metodologia para projetos de Urbanização. Tese de Doutorado - Faculdade de Arquitetura e Urbanismo da Universidade de São Paulo (FAU-USP), São Paulo, 2000.

BUENO, Laura Machado Mello; MARTINS, M. L. Reffinetti (org.). SEMINÁRIO NACIONAL SOBRE O TRATAMENTO DE ÁREAS DE PRESERVAÇÃO PERMANENTE EM MEIO URBANO E RESTRIÇÕES AMBIENTAIS AO PARCELAMENTO DO SOLO. Anais do Seminário Nacional sobre o Tratamento de Áreas de Preservação Permanente em Meio Urbano e Restrições Ambientais ao Parcelamento do Solo. São Paulo: FAU-USP, 2007.

CALDEIRA, Teresa Pires do Rio. Cidade de Muros: Crime, segregação e cidadania em São Paulo. São Paulo: Editora34; EDUSP, 2000

CAUQUELIN, Anne. A Invenção da Paisagem. São Paulo: Martins Fontes, 2007.

CHAUİ, Marilena. Cidadania cultural: O direito à cultura. São Paulo: Editora Perseu Abramo, 2006. . O que é ideologia. São Paulo: Editora Brasiliense, 2006.

D'ANDREA, Tiarajú Pablo. A formação dos sujeitos periféricos: cultura e política na periferia de São Paulo. Tese de Doutorado - Faculdade de Arquitetura e Urbanismo da Universidade de São Paulo (FAU-USP), São Paulo, 2013.

DAVIS, Mike. Planeta Favela. São Paulo: Boitempo, 2006.

DEFENSORIA PÚBLICA DO ESTADO DE SÃO PAULO. Relatórios técnicos de acompanhamento do processo de regularização fundiária do Jardim Jaqueline. São Paulo, 2012.

FIX, Mariana. Parceiros da exclusão: duas histórias da construção de uma nova cidade em São Paulo - Faria Lima e Água Espraiada. São Paulo: Boitempo, 2011. 
FOUCAULT, M. A Vida dos homens infames. Ditos e escritos IV. Rio de Janeiro: Forense Universitária, [19--], p. $203-222$.

GARNICA, Antonio Vicente Marafioti. Algumas notas sobre Pesquisa Qualitativa e Fenomenologia. In: PARADIGMAS DE INTERPRETAÇÃO DA REALIDADE, 1996, Botucatu. Mesa-redonda organizada pelas disciplinas de Pedagogia Médica e Didática Especial do Departamento de Educação. Botucatu: UNESP, 1996. Disponível em: <http://www.scielo.br/pdf/icse/ v1n1/08.pdf>. Acesso em: 29 Jul. 2013.

HARVEY, David. A Produção Capitalista do Espaço. São Paulo: Annablume, 2006.

. O Trabalho, o Capital e o Conflito de Classes em Torno do Ambiente Construído, nas Sociedades Capitalistas Avançadas. Espaço \& Debates, n. 6, jan./set., 1982, p. 6.

HELLER, Agnes. O Cotidiano e a História. São paulo: Paz e Terra, 2008.

HIRATA, Daniel; TELLES, Vera da Silva. Cidade e Práticas Urbanas: nas fronteiras incertas entre o ilegal, o informal e o ilícito. In: KOWARICK, Lucio; MARQUES Eduardo. São Paulo: novos Percursos e Atores. São Paulo: Editora 34; Centro de Estudos da Metrópole, 2011.

LEI FEDERAL n 10.257 de 10 de julho de 2001 - Estatuto da Cidade.

LEI FEDERAL n 11.977 de 7 de julho de 2009 - Minha Casa Minha Vida.

MARCUSE, Peter. O caso contra os direitos de propriedade. In: VALENÇA, Márcio (org.) Cidade (I)legal. Rio de Janeiro: Mauad X, 2008

MARICATO, Ermínia. Habitação e as Políticas Urbana, Fundiária e Ambiental. Brasília: Ministério das Relações Exteriores/PNUD, 1995.

. Nunca fomos tão participativos. Carta Maior, 26 Nov. 2007. Disponível em: <http://www.cartamaior.com.br/ templates/colunaMostrar.cfm?coluna_id=3774>. Acesso em: 23 Maio 2012.

MARICATO, Erminia; FERREIRA, João Sette Whitaker. Operação Urbana Consorciada: diversificação urbanística participativa ou aprofundamento da desigualdade? In: OSÓRIO, Letícia Marques (org.). Estatuto da Cidade e reforma urbana: novas perspectivas para as cidades brasileiras. Porto Alegre; São Paulo: Sérgio Antonio Fabris Editor, 2002.

MARQUES Eduardo; SARAIVA, Camila. Favelas e Periferias nos anos 2000. In: KOWARICK, Lucio; MARQUES Eduardo. São Paulo: novos Percursos e Atores. São Paulo: Editora 34; Centro de Estudos da Metrópole, 2011.

. A dinâmica social das favelas da Região Metropolitana de São Paulo. SEMINÁRIO SOBRE ESTRUTURA SOCIAL E SEGREGAÇÃo ESPACIAL, São Paulo, Rio de Janeiro e Paris, 2003. Anais do Seminário sobre Estrutura Social e Segrega- 
ção Espacial. Disponivel em: <www.centrodametropole.org.br>. Acesso em: 9 Mar. 2012.

MARTINS, Joel. A pesquisa qualitativa em psicologia: fundamentos e recursos básicos. $5^{a}$ ed. São Paulo: Centauro, 2005.

MENEZES, Ulpiano Bezerra de. A paisagem como fato cultural. In: YÁZIGI, Eduardo (org.). Turismo e Paisagem. São Paulo: Contexto, 2002.

OLIVEIRA, Francisco de. O Estado e o Urbano no Brasil. Espaço \& Debates, n. 7, dez., 1982.

(org.). Os sentidos da democracia: políticas do dissenso e hegemonia global. Petrópolis: Vozes, 1999.

PALLAMIN, Vera. Cidade e cultura: conflito urbano e a ética do reconhecimento. Rua, 2012, v. 2, n. 18.

. Espaço público e as lutas por reconhecimento. Espaço \& Debates, v. 25, n. 46, jul., 2005.

PALLAMIN, Vera M. (org). Cidade e Cultura: esfera pública e transformação urbana. São Paulo: Estação Liberdade, 2002.

PREFEITURA DO MUNICÍPIO DE SÃO PAULO. Base cartográfica das favelas do Município de São Paulo. Secretaria de Habitação e Desenvolvimento Urbano (SEHAB), Centro de estudos da Metrópole (CEM), Companhia de Processamento de Dados do Município de São Paulo (PRODAM). São Paulo, 2003.

RUGGIERO, V.; SOUTH N. The late city as a bazaar: drug markets, illegal enterprise and the barricades. The British Journal of Sociology, v. 48, n. 1, 1997, p. 54-70.

SANTOS, Boaventura de Sousa. Pela Mão de Alice: o social e o político na pós-modernidade. 13ª ed. Cortez: São Paulo, 2010.

SANTOS, Catharina P. C. Anotações em sala de aula, disciplina "A paisagem no desenho do cotidiano (AUP 5834)".

Revista da Pós-graduação, FAU-USP, no prelo.

SERRÃO, Adriana. Pensar a Natureza e Trazer a Paisagem à Cidade. In: VICHIETTI, Sandra Maria. Psicologia Social e Imaginário. São Paulo: Zagodoni Editora, 2012.

SILVA, Helena Menna Barreto. Programas de Urbanização e desenvolvimento do mercado em favelas brasileiras. LINCOLN INSTITUTE OF LAND POLICY, 2000. Disponível: < http://www.lincolninst.edu/pubs/701_Programas-de-urbaniza\%С3\%A7\%С3\%A3o-e-desenvolvimento-do-mercado-em-favelas-brasileiras>. Acesso em: 20 Ago. 2013.

SINDICATO NACIONAL DAS EMPRESAS DE ARQUITETURA E ENGENHARIA CONSULTIVA. Parques Paulistanos: estudo sobre uso e manutenção. Sinaenco: São Paulo, 2008. Disponivel em: <http://www.nossasaopaulo.org.br/portal/files/EstudoParques.pdf>. Acesso em: 10 Ago. 2013. 
SMITH, Neil. The new urban frontiers: gentrification and the revanchist city. Londres: Routledge, 1996.

TAYLOR, Charles. Argumentos filosóficos. Tradução A. U. Sobral. São Paulo: Loyola, 2000.

THIOLLENT, Michel. Metodologia da Pesquisa-Ação. 18 ed. Cortez: São Paulo, 2011.

TORRES, H. G.; MARQUES, E.C.; SARAIVA C. Favelas no Município de São Paulo: estimativas de população para os anos de 1991, 1996 e 2000. ENCONTRO DA ASSOCIAÇÃO NAOCIONAL DE PLANEJAMENTO URBANO E REGIONAL (ANPUR), Belo Horizonte, 2003. Anais. Disponivel em: <http://www.centrodametropole.org.br>. Acesso em: 20 Ago. 2013.

VILLAÇA, Flávio. Espaço Intra-Urbano no Brasil. São Paulo: Studio Nobel, 1998. (1) Jan. 2012.

ZUKIN, Sharon. Paisagens urbanas pós-modernas: mapeando cultura e poder. In ARANTES, Antônio Augusto (org). O espaço da diferença. Campinas: Papirus, 2000.

\section{ARTIGOS JORNAIS}

ANDRADE, Hanrrikson de. Desaparecimentos em favelas do Rio aumentam após início das UPPs. UOL Notícias, 3 Ago. 2013. Disponivel em: <http://noticias.uol.com.br/cotidiano/ultimas-noticias/2013/08/03/desaparecimentos-aumentaram-em-favelas-do-rio-apos-inicio-das-upps.htm>. Acesso em: 20 Ago. 2013.

BRANCATELLI, Rodrigo; ZANCHETTA, Diego. Por que shoppings viraram alvo do Ministério Público em São Paulo? O Estado de S. Paulo, São Paulo, 23 Jun. 2012. Disponivel em: <http://www.estadao.com.br/noticias/cidades,porque-shoppings-viraram-alvo-do-ministerio-publico-em-sao-paulo,890653,0.htm>. Acesso em: 10 Ago. 2013.

O GLOBO. Imóveis em favelas com UPP sobem até 400\%. O Globo, Rio de Janeiro, 29 Maio 2010. Disponível em: <http://oglobo.globo.com/rio/imoveis-em-favelas-com-upp-sobem-ate-400-3001504>. Acesso em: 10 Ago. 2013.

VASQUES, Daniel. Área útil menor faz apartamento ser indicado a solteiros. Folha de S. Paulo [IT.], São Paulo, 27 Jan. 2013. Disponivel em:<http://www1.folha.uol.com.br/fsp/imoveis/90736-area-util-menor-faz-apartamento-ser-indicado-a-solteiros.shtml>. Acesso em: 20 Ago. 2013. 


\section{SITES PESQUISADOS}

CEM - Centro de Estudos da Metrópole. São Paulo. Base Cartográfica digital das favelas do MSP. Disponível em: <http://www.centrodametropole.org.br/base_cart.html>. Acesso em: 8 Mar. 2012.

FUNDAÇÃO SEADE - Fundação Sistema Estadual de Analise de Dados. Disponível em: <http://www.seade.gov.br>. Acesso em: 20 Ago. 2013.

IBGE - Instituto Brasileiro de Geografia e Estatística. Disponivel em: <http://www.ibge.gov.br/cidadesat/topwindow. htm?1>. Acesso em: 20 Ago. 2013.

SEMPLA - Secretaria Municipal de Planejamento de São Paulo. Disponivel em: <http://www.prodam.sp.gov.br/sempla/zone.htm>. Acesso em: 20 Ago. 2013. 
Dissertaçáo finalizada e depositada no inverno de 2013, em São Paulo. 